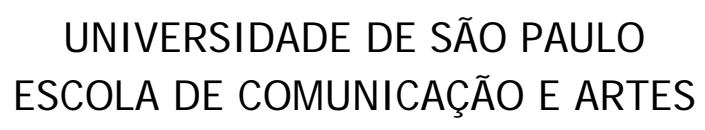

\title{
A importância das regras e do gameplay no envolvimento do jogador de videogame
}

Hélia Vannucchi de Almeida Santos 

HÉLIA VANNUCCHI DE ALMEIDA SANTOS

\section{A importância das regras e do gameplay no envolvimento do jogador de videogame}

Tese apresentada ao Programa de Pós-Graduação em Artes Visuais, Área de Concentração Poéticas Visuais, Linha de Pesquisa Multimeios, da Escola de Comunicações e Artes da Universidade de São Paulo, como exigência parcial para obtenção do Título de Doutor em Artes Visuais, sob a orientação do Prof. Dr. Gilberto dos Santos Prado.

São Paulo 

Banca Examinadora 

Para o Vermelho,

por dividir sonhos e sucessos,

por ter escolhido tornar-se um comigo, e por acreditar sempre. 



\section{Agradecimentos}

Ao meu orientador Gilbertto Prado, por mais essa orientação, pela confiança e apoio durante todo o trajeto.

Ao amigo Jesus de Paula Assis, por seu apoio desde o início, pelas discussões e leituras atentas que tanto enriqueceram este trabalho.

A Silvia Laurentiz, pelo carinho e pelas contribuições na qualificação.

Ao meu pai, David e minha mãe Maria Luiza, pelo apoio incondicional. Ainda à minha mãe, pela revisão atenta e urgente de toda a tese.

A todos os amigos que foram interlocutores, que dedicaram ao menos uma parte do seu tempo, e em especial aos integrantes do blog e lista de discussão Realidade Sintética, principalmente, o Paolo Bruni e o Enric Llagostera, pelas opiniões honestas.

À minha família e a todos os meus amigos, pela confiança, apoio e incondicional amizade. 



\section{Resumo}

Este trabalho tem como intuito trazer luz a elementos que possibilitem o claro entendimento dos conceitos responsáveis pelo envolvimento do jogador com o jogo, em especial, as regras e o gameplay, que consideramos como primordiais para a construção de sua experiência de jogar. Neste intento, partimos do entendimento do conceito de jogo, buscando identificar os elementos que são importantes para que um jogo se constitua como tal, derivando os que consideramos ser essenciais ao jogo. Discutimos os conceitos de regras e gameplay, seus tipos e elementos, e as relações e as influências que se estabelecem entre eles. Observamos que quando 0 jogo apresenta um desafio ao jogador, que o coloca imerso no ambiente do jogo, a manipulação das mecânicas e da combinação das regras lhe permitirá experimentar a emergência de novos elementos, decorrentes de sua agência, e capazes de the porporcionar uma experiência gratificante e prazerosa.

Palavras-chave: regras, gameplay, videogame, jogador, experiência lúdica. 



\section{Abstract}

The work is concerned primarily to point out some elements that can clarify the understanding of the concepts responsible by the player engagement with the game; the rules and the gameplay are the elements, considered as principal, to construct the experience of playing. Comprehending the concept of the game, we tried to identify the elements responsible for that. The rules and the gameplay concepts, types and elements, and their interrelations have been discussed. The challenge proposed by the game can create an immersive condition to the player; the mechanics manipulation and the rules combination will evoke the emergence of new elements and turn this experimentation enjoyable and grateful.

Keywords: rules, gameplay, videogame, player, ludic experience. 



\section{Sumário}

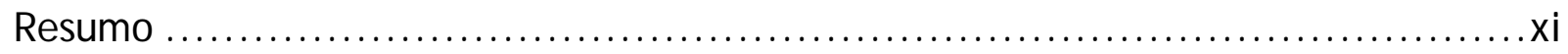

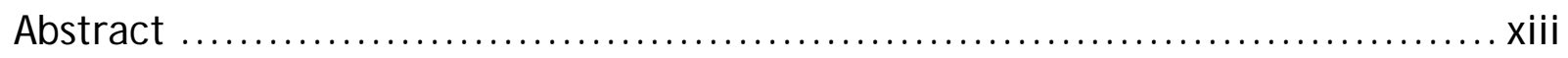

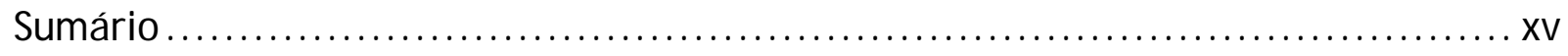

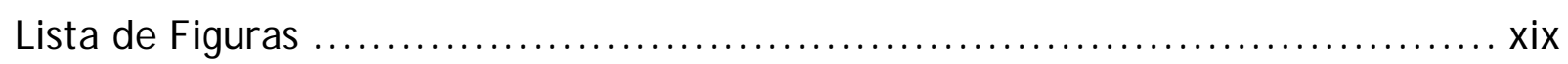

Lista de gráficos, tabelas e quadros........................................

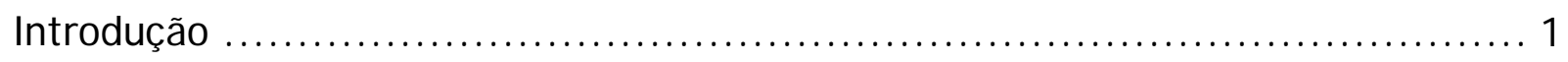

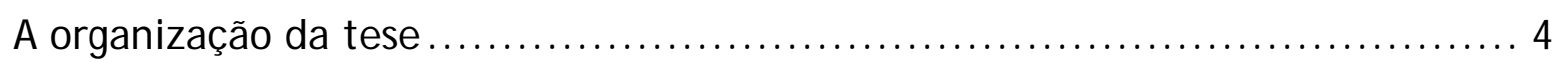

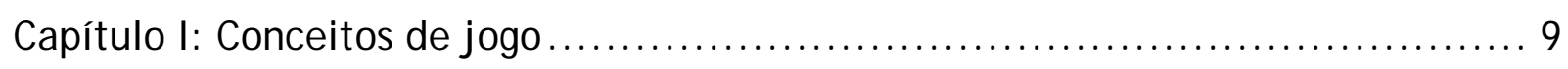

1.1. Diferenças entre videogame e seus precursores não eletrônicos .......... 11

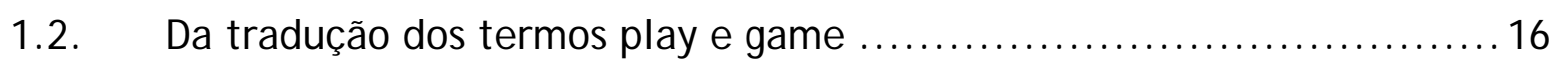

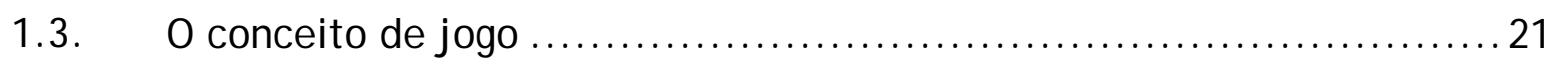

1.3.1. Organização dos conceitos de jogo, por Salen \& Zimmerman ...... 21

1.3.2. Organização dos conceitos de jogo, por J esper J uul ............... 34

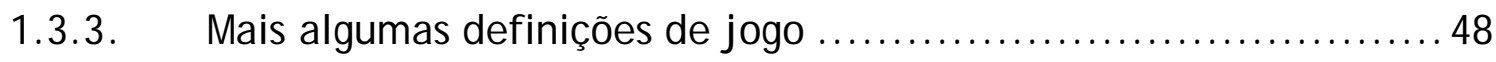

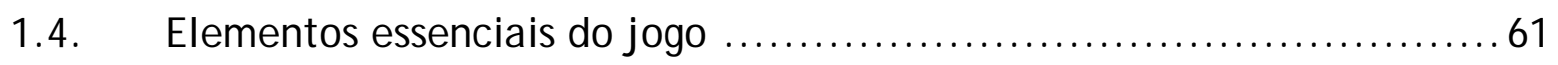

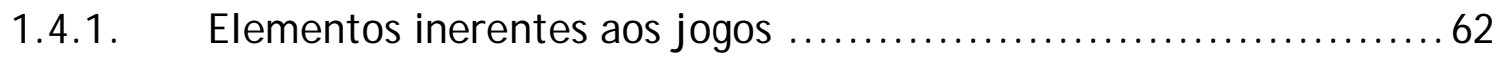

1.4.2. Elementos decorrentes do ato de jogar....................... 74 
Capítulo II: Regras e Gameplay.

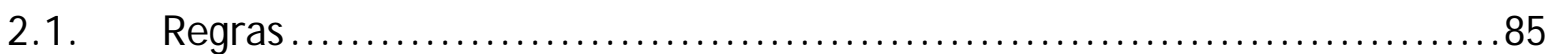

2.1.1. Diferentes tipos de regras ................................. 94

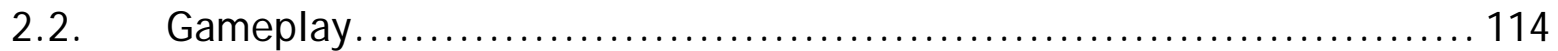

2.2.1. 0 conceito de gameplay por diversos autores $\ldots \ldots \ldots \ldots \ldots \ldots \ldots 116$

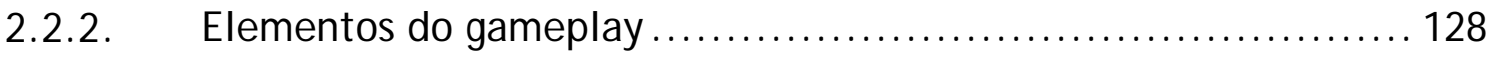

Capítulo III: As relações entre regra, gameplay e seus elementos................. 169

Capítulo IV: Análise do game Cozinheiro das Almas........................... 185

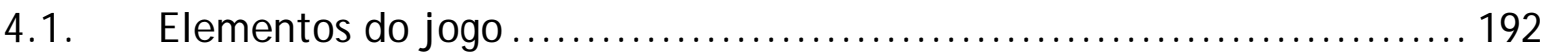

- $\quad$ Regras........................................................ 192

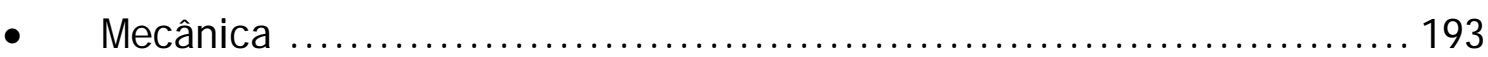

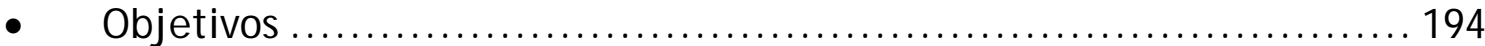

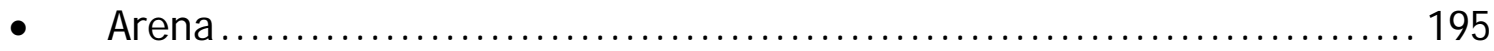

- Fator de incerteza ............................................. 199

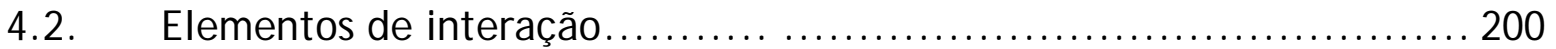

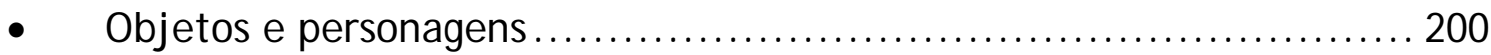

$\quad$ Movimentos .................................................... 202

- $\quad$ Orientação e feedback ................................................ 203

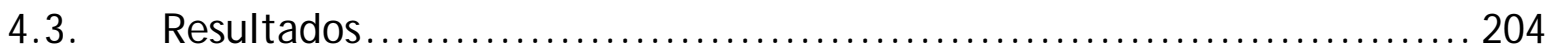

4.4. Bibliografia de referência para o game Cozinheiro das Almas.......... 207 
Conclusão

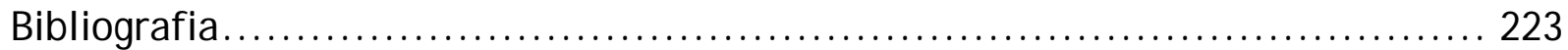

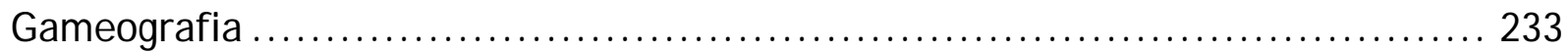





\section{Lista de Figuras}

Figura 1. Genius da Estrela. .......................................... 10

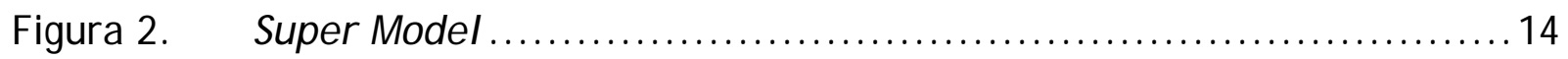

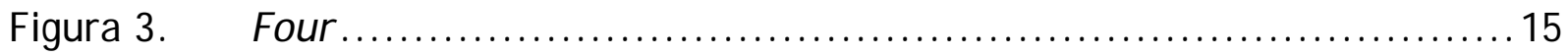

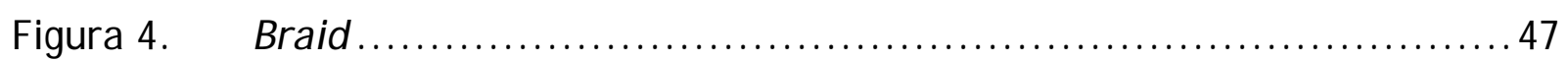

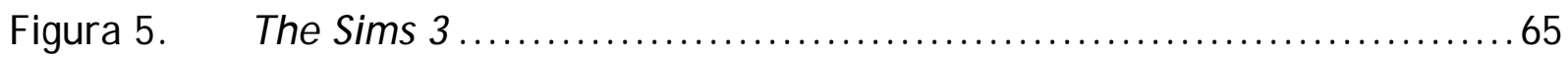

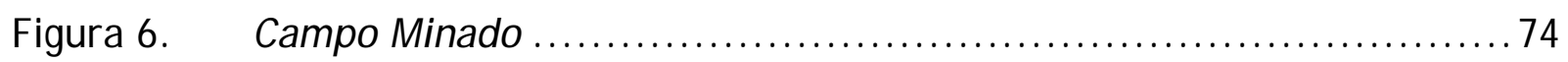

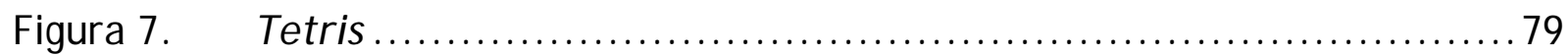

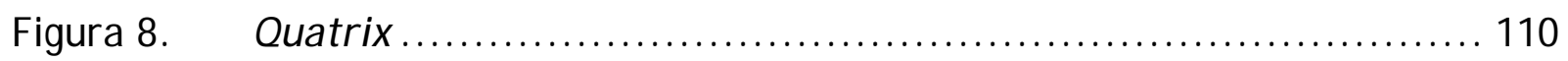

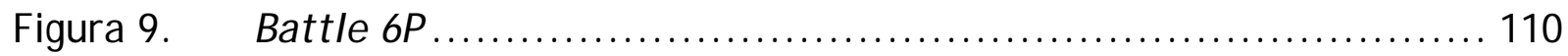

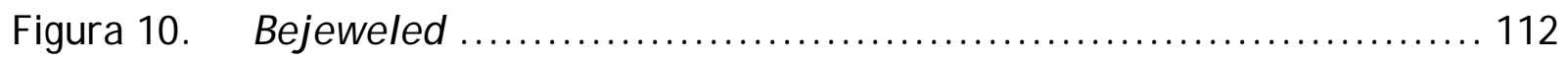

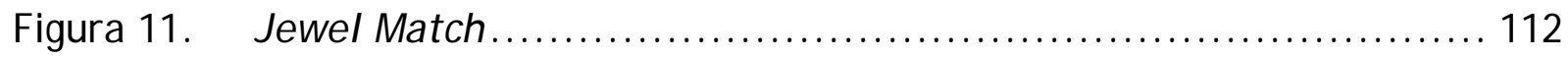

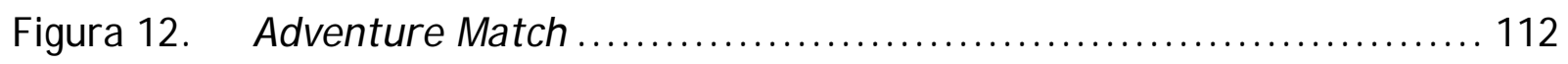

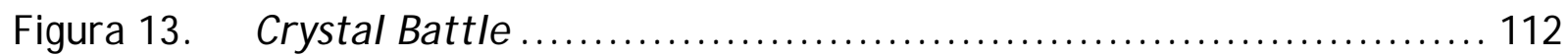

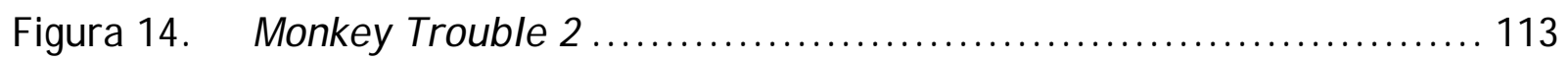

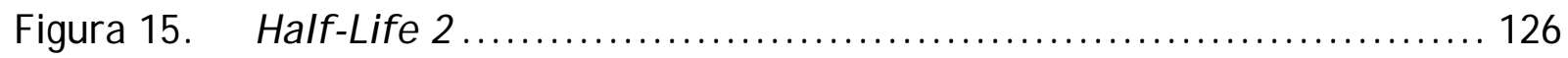

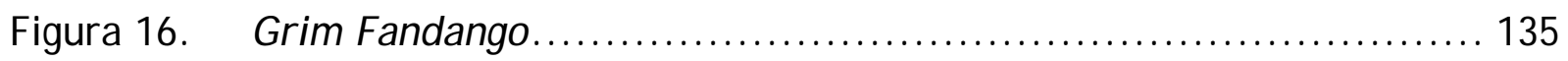

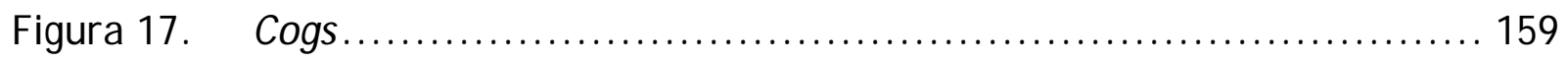

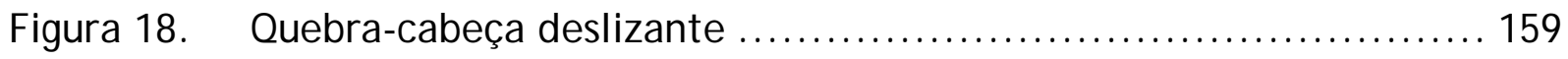

Figura 19. Imagens de referência para o game............................ 189

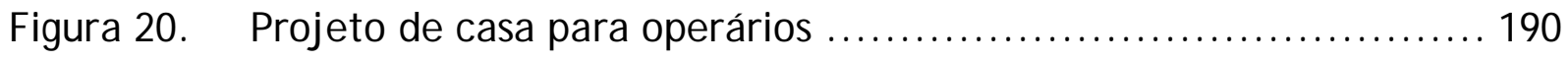


Figura 21. Casinhas do tipo mínimo .................................... 190

Figura 22. $\quad$ Atividades do Grupo Escolar, c. 1818. ............................. 191

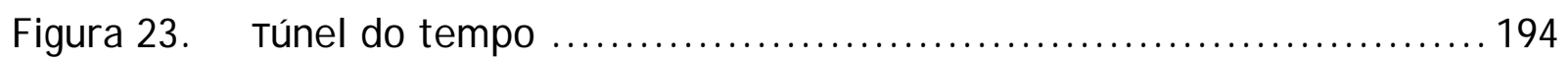

Figura 24. Imagem do jogo, a garçonnière em 1918........................ 196

Figura 25. Imagem do jogo, Escola Normal e J ardim de Infância. ............... 199

Figura 26. Imagem do jogo, grupo de personagens na Escola Normal. .......... 201 


\section{Lista de gráficos, tabelas e quadros}

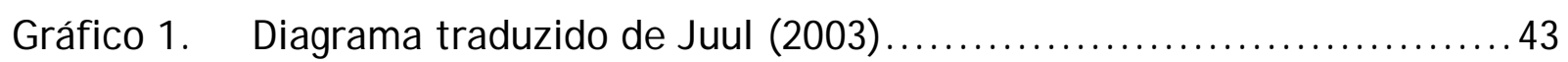

Gráfico 2. Intersecção entre o jogo e o jogador, 0 ato de jogar.................61 61

Tabela 1. Comparação dos elementos de jogo (traduzida de Salen \& Zimmerman) . 28

Tabela 2. Comparações das definições de jogo (traduzida de J uul) ............... 37

Tabela 3. O modelo clássico de jogo, o jogo, o jogador e o mundo (traduzida de

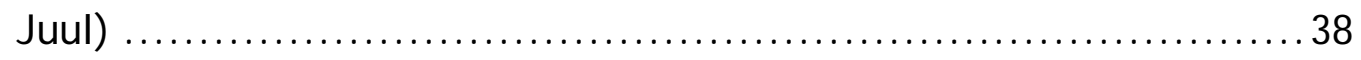

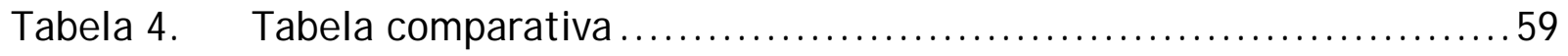

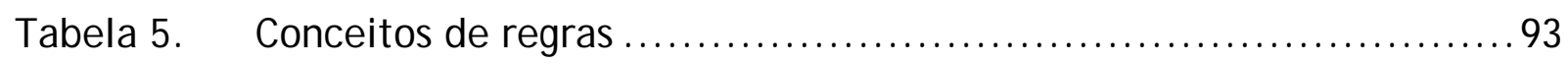

Tabela $6 . \quad$ Tipos de regras................................................ 96

Tabela 7. Definições de gameplay ...................................... 120

Tabela 8. Videogames e seis definições de narrativa (traduzida de J uul) ....... 141

Tabela 9. Relação entre os elementos do jogo e os constituintes do gameplay 180

Quadro 1. Resumo dos elementos esssenciais do jogo. $\ldots \ldots \ldots \ldots \ldots \ldots \ldots \ldots \ldots . \ldots 3$ 



\section{Introdução}

“Jogos são mágicos, como o primeiro beijo é mágico". (Zimmerman, in: Fullerton, 2008:XIII)

Este trabalho tem como intuito fornecer subsídios conceituais que ajudem a entender os elementos que possibilitam o envolvimento do jogador com o jogo, em especial, as regras e o gameplay.

Consideramos as regras e o gameplay elementos primordiais para a construção da experiência do jogador, o que não significa que essa experiência prescinda de outros aspectos relevantes. Assim, buscamos no que segue compreender quais são e como estes elementos trabal ham para o engajamento do jogador.

Neste intento, partimos do entendimento do conceito de jogo, buscando identificar os elementos que são importantes para que um jogo se constitua como tal. Dividimos estes elementos essenciais aos jogos em dois tipos, os que são inerentes a eles e os decorrentes do ato de jogar. 
As regras, como apontou Frasca (1997), "estão profundamente relacionadas aos problemas colocados pelo jogo ao jogador". Então, consideramos importante compreender seu papel, por serem elas um importante elemento definidor das características e da originalidade de um jogo. Cada conjunto de regras torna um jogo único. E, para o jogador, estabelecem os limites e orientam a sua agência por meio da criação das estratégias a serem adotadas.

A observação da existência de diversos tipos de regras e a compreensão das funções de cada um dos seus tipos também ajudam o pesquisador a pensar e organizar a experiência do jogador.

Da interação do jogador com o jogo, a partir de seu envolvimento com as regras e da manipulação de suas mecânicas, emerge o gameplay. Durante nossa pesquisa nos deparamos com dois problemas principais a respeito do termo. Primeiro a respeito da validade ou não de sua tradução pela palavra jogabilidade. Em segundo lugar, a falta de consenso com relação ao seu próprio significado. Buscando jogar uma luz sobre estes problemas apontamos as inconveniências da tradução do termo gameplay por jogabilidade, sugerindo o seu uso no original e propomos uma definição que o explique.

O conceito de gameplay, a exemplo do conceito de jogo, também trazia nas discussões de diversos autores, a descrição de elementos que despontavam como 
característicos. Nós os organizamos, mais uma vez, dividindo-os em elementos que fazem parte do gameplay e os que nele interferem.

Na construção do gameplay consideramos agência, emergência e imersão como elementos importantes pela influência direta que estes elementos têm sobre 0 jogador. Agência e imersão são dois conceitos ligados aos prazeres característicos do ambiente digital elencados por Murray (2003: 101-176). Em nossa análise, a transformação (o terceiro prazer citado pela autora) é substituída pela emergência. Com relação aos videogames, consideramos, pois, que a emergência vai além da transformação, já que possibilita não só a variedade em si como o surgimento de elementos inesperados e até inusitados.

Ainda com respeito à imersão, avançamos a discussão dos tipos propostos por Ryan (2001:120-157), adaptando-os para os videogames e identificando um incremento de grau nesta tipificação.

A título de resumir esta introdução, podemos dizer que este trabalho se propõe trazer luz a elementos que possibilitem o claro entendimento dos conceitos responsáveis pelo envolvimento do jogador com o jogo e pela construção de sua experiência de jogar, que passa pelo desenvolvimento e incremento de suas habilidades e pela ampliação de seu repertório lúdico. 


\section{A organização da tese}

O primeiro capítulo trata dos conceitos e dos elementos do jogo. Os conceitos de jogo já foram alvo de levantamentos realizados por diversos autores. Nosso obj etivo não é fazer um levantamento exaustivo de todas as definições de jogo já formuladas, mas apontar algumas e as formas como foram tratadas ao longo do tempo. Para isso partimos dos comparativos realizados por Salen \& Zimmerman (2003) e por J uul (2003) e de suas análises para apresentar e discutir o conceito de jogo.

Desta discussão derivamos elementos que consideramos ser essenciais ao jogo, observando que alguns, como os objetivos, a interação, o espaço onde este acontece (que chamamos de arena) e o fato de ser uma atividade voluntária e com resultado incerto, são inerentes aos jogos; enquanto que os resultados alcançados, a competição e o faz-de-conta são elementos decorrentes do ato de jogar.

Regras e gameplay são discutidos no segundo capítulo. São levantados diversos conceitos de regra e seus elementos, para os quais buscamos um entendimento e uma proposta de organização de elementos, adotando basicamente a divisão dos elementos de regras já estabelecida por Frasca (1997), subdivindo o que o autor chamou de regras de desenvolvimento em duas outras categorias (regras regentes e regras orientadoras) para melhor acolher as diferenças apontadas pelos outros autores. 
A discussão de gameplay parte da elaboração de uma síntese dos discursos em língua inglesa sobre o conceito, para em seguida, propor uma definição e observar que existem elementos que o constituem, como a atitude lúdica, a jogabilidade, a narrativa e a interface, e outros que nele interferem: imersão, agência e emergência. Estes elementos são individualmente discutidos neste segundo capítulo.

O terceiro capítulo trata das relações entre as regras e o gameplay, observando as influências que se estabelecem entre eles. Consideramos que é a partir das ações que o jogador realiza dentro do ambiente do jogo (agência), combinadas com a possibilidade de encontrar caminhos impensados, que surgem da combinação das regras (emergência), e de sua imersão dentro do ambiente do jogo que o gameplay se instaura.

Regras e gameplay são elementos primordiais para a construção da experiência do jogador. Mas é em conjunto com os elementos inerentes aos jogos e os constituintes do gameplay que elaboram esta experiência.

Assim, observamos que quando o jogo apresenta ao jogador, imerso no ambiente do jogo, um desafio, este Ihe possibilita, por meio da manipulação das mecânicas e da combinação das regras, a experimentação da emergência de novos elementos, que surgem de sua agência sobre o jogo. Agência que se traduz pela realização de ações significativas, geradas a partir de escolhas informadas e possibilitadas pelas 
informações disponibilizadas pelo sistema. Informações que são organizadas a partir da interação entre os elementos do jogo, as regras e o gameplay.

O capítulo 4 traz um estudo de caso, uma análise do game Cozinheiro das Almas, baseada nas discussões sobre regras, gameplay (entendido em conjunto com elementos que o compõe e que nele interferem) e outros elementos essenciais aos jogos, observando como cada um deles contribui para a construção da experiência do jogador.

O videogame foi desenvolvido pelo Grupo de Pesquisa em Poéticas Digitais (ECAUSP), a partir do livro "O Perfeito Cozinheiro das Almas deste Mundo", diário da garçonnière mantida por Oswald de Andrade entre 1918 e 1919. No game 0 personagem principal se perde na São Paulo de 1918 e visita interativamente vários ambientes nos quais vai, aos poucos, descobrindo a trama, que se passa em um só dia.

O jogo apresenta duas motivações distintas que se entrelaçam: a exploração do ambiente e a procura por objetos perdidos no passado, para recolocá-los em seu lugar, no tempo presente, sob pena de destruir a tessitura do tempo e com isso destruir o tempo presente como o conhecemos.

Uma das intenções no desenvolvimento do game é que o ambiente ficcional de ação seja também historicamente preciso. 
Enquanto ambiente de ação, o jogo configura-se como um labirinto espacial e temporal, puramente exploratório, cuja missão o jogador deve descobrir enquanto se aventura pelos ambientes.

O game Cozinheiro das Almas foi premiado na 6a edição do Prêmio Sergio Motta de Arte e Tecnologia (2005/06). A versão demo deste trabalho foi exibida na Mostra exposição coletiva, Interconnect@ between attention and immersion, ZKMZentrum für Kunst und Medientechnologie, Karlsruhe - Alemanha, de 01 de setembro a 15 de outubro de 2006, curadoria Peter Weibel e Daniela Bousso, coord. Bernhard Serexhe e também na Exposição Arte Computacional e Pesquisa, Espaço Cultural 508 Sul, Brasília, curadoria de Suzete Venturelli, em 2007. Nestas versões foram construídas a garçonnière, em 2006 e 1918, assim como a Escola Normal e 0 J ardim da Infância, em horários distintos, o que permitiu ao visitante experienciar a poética do trabalho, percorrer os espaços criados e jogar em pelo menos dois ambientes. 



\section{Capítulo l: Conceitos de jogo}

“Como substantivo, jogo e os seus homólogos neo-latinos se referem a toda e qualquer atividade desenvolvida para a recreação do espírito, para distração, para o entretenimento". (J. P. Machado, in: Lopes, 2005:5)

O universo dos jogos compreende as brincadeiras de rodas das crianças (que usualmente chamamos de brincadeiras), os jogos de azar (apostas), os jogos de tabuleiro, de ação (como paintball) e os videogames.

Para fins de nosso estudo, nos ateremos aos videogames, jogos que se desenvolvem via computador e utilizam uma tela para sua visualização. Em alguns momentos, a título de comparação nos referiremos aos jogos de tabuleiro (como os conhecidos Banco Imobiliário e War) e principalmente, aos jogos tidos como tradicionais (que são aqueles consagrados pelo tempo e por sua disseminação entre diversos povos, como Damas, Gamão ou Go, por exemplo).

Para Santaella (2004), o termo mais correto em língua portuguesa, para designar genericamente tanto os jogos que se desenvolvem via computador ou utilizando consoles, seria jogo eletrônico. 
No entanto, entendemos que o termo jogo eletrônico pode englobar outros tipos de jogos que não utilizem uma tela para sua visualização, como o antigo Genius, lançado pela primeira vez no Brasil em 1980, pela Estrela $^{1}$, cujo objetivo era acertar a sequência de sons e luzes determinada pela máquina.

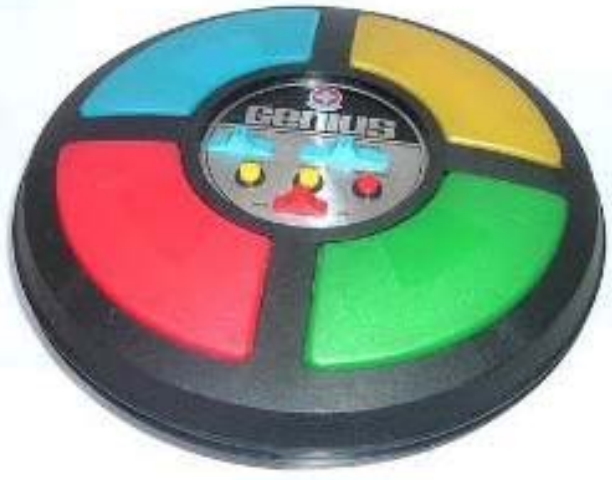

Figura 1. Genius da Estrela. Jogo eletrônico que se tornou sucesso nos anos 80 .

Para Nesteriuk (2002:78), a adoção do termo videogame para se referir genericamente às diversas plataformas nas quais os jogos eletrônicos podem se desenvolver deve-se tanto ao fato de seu desenvolvimento comum quanto em função de utilizarem o computador para produzir e processar os jogos. Esta mesma generalização é feita por Frasca (2001).

Como nossa análise se foca nos jogos que utilizam uma tela para sua visualização, preferimos o termo videogame, assim como Frasca e Nesteriuk, até porque, em termos de aplicação de regras, não existe diferença substancial no desenvolvimento

1 O jogo foi relançado recentemente pela própria Estrela com o nome de Genius Simon, incorporando assim o nome com que o jogo era vendido nos Estados Unidos quando foi lançado naquele mercado em 1978. 
de um jogo em console dedicado, em um console acoplado a um monitor ou em um computador ${ }^{2}$.

\subsection{Diferenças entre videogame e seus precursores não eletrônicos}

Para J uul (2004:140)

a principal diferença entre um jogo computacional e seus precursores não eletrônicos é que os jogos computacionais adicionam automação e complexidade - eles podem manter e calcular as regras do jogo por si mesmos, possibilitando, portanto, mundos de jogo mais ricos ${ }^{3}$.

Em um artigo anterior, de 2000, J uul aponta quatro características principais que os videogames introduzem e que os distinguem dos jogos não-computadorizados: tempo, automação/complexidade, repetição (replay) e nível. Tempo e automação/ complexidade, segundo o autor, são características mais óbvias, mais fáceis de serem percebidas e mais ou menos quantitativas, enquanto as duas últimas (repetição e nível) se apresentam de forma mais sutil. Para Juul, cada uma destas características pode ser observada em um ou mais tipo de videogame.

O tempo, nos videogames, possui características próprias, já que o computador pode acompanhar o ritmo que imprimimos ao jogo. E isto nos permite criar novas

\footnotetext{
${ }^{2}$ Para mais informações sobre plataformas ver Nesteriuk (2002:77) e Luz (2009:25-27).

${ }^{3}$ Tradução nossa. Do original em inglês: "The main difference between the computer game and its non-electronic precursors is that computer games add automation and complexity - they can uphold and calculate game rules on their own, thereby allowing for richer game worlds" (J uul, 2004: 140)
} 
possibilidades, já que podemos "criar jogos em tempo real sem precisar confiar nas leis da Física" ${ }^{4}$. Jogos de ação e velocidade se valem desta característica, mas é nos jogos de tiro em primeira pessoa (first person shooter) que esta característica é mais perceptível.

No entanto, não acreditamos ser esta uma característica que marque uma diferença essencial entre os videogames e os jogos não-eletrônicos. Embora o tempo possa ser trabalhado de maneira diferente nos dois suportes, está presente nas duas modalidades.

Os quebra-cabeças (puzzles) podem ser exemplos de jogos que se beneficiam das possibilidades de repetição (replay). Mas não são os únicos. Para J uul, a repetição é entendida tanto como a opção de retornar ao mesmo jogo, no sentido de poder voltar ao mesmo desafio, jogar um nível do mesmo jogo de novo quanto como a possibilidade de salvar uma determinada posição em um jogo; já que, de qualquer modo, o jogador pode enfrentar novamente o mesmo desafio. Em 2004, ao analisar mais de perto a questão do tempo, J uul apresenta argumentos a favor e contrários ao recurso de salvar o jogo. 0 principal argumento a favor é que muitos dos jogos atuais não são projetados para serem levados a cabo em uma única sessão. E 0 principal argumento contra é que este recurso diminui a tensão dramática do jogo, "uma vez que o jogador simplesmente recarrega se algo der errado". No entanto,

\footnotetext{
${ }^{4}$ Tradução nossa. Do original em inglês: "With computer games, you can create real-time games without having to rely on laws of physics." (J uul, 2000)
} 
ao final da discussão de todos os argumentos pró e contra, o autor conclui que "salvar jogos provavelmente não é um mal a ser evitado a todo o custo" ${ }^{5}$.

Para nós a repetição também não é uma exclusividade dos videogames, pois poder voltar ao mesmo desafio é equivalente a jogar novamente uma partida de um jogo qualquer. Se o jogo é do tipo quebra-cabeça é indiferente o suporte onde este se desenvolve, e o desafio estará também na proposição do próprio jogador de se desafiar com aquele jogo. Se o jogo depende de um outro participante, também é indistinto se este jogador é um outro humano ou o computador, pois, dentre as variáveis possíveis, dificilmente as jogadas serão tão idênticas assim.

Para J uul (2000), os níveis acrescentam novos desafios a cada nova fase do jogo. E a revolução se inicia com Space Invaders (criado por Tomohiro Nishikado, e Iançado em 1978 pela Taito Corporation) onde, a cada mudança de nível (ou fase) ficava cada vez mais difícil nos defendermos dos alienígenas. Assim como J uul, para Assis (2007:10-11), as "fases" dos videogames introduzem um "elemento radicalmente diferente na experiência de jogar", podendo a mudança de fase ser apenas um estágio contínuo do anterior ou apresentar uma experiência radicalmente diferente.

\footnotetext{
${ }^{5}$ Tradução nossa. Do original em inglês: "Save games are probably not an evil to be avoided at all costs". (J uul, 2004:138).
} 
No entanto, podemos observar níveis também em outros jogos que não nos videogames. 0 jogo Resta Um, por exemplo, tem como objetivo deixar apenas uma peça sobre o tabuleiro e como objetivo avançado, deixar esta única peça na casa central do tabuleiro. Assim como este jogo, podemos citar outros dois de tabuleiro criados por mim para a GMK: Four, produzido e comercializado pela Philos-Spiele, na Alemanha e Super Model, produzido e comercializado no Brasil pela Toyster, sob o selo da linha Game Office. O jogo Four, assim como o Resta Um, traz um objetivo e um objetivo avançado. Já o jogo Super Model possui três fases distintas com mecânicas diferentes em cada fase.

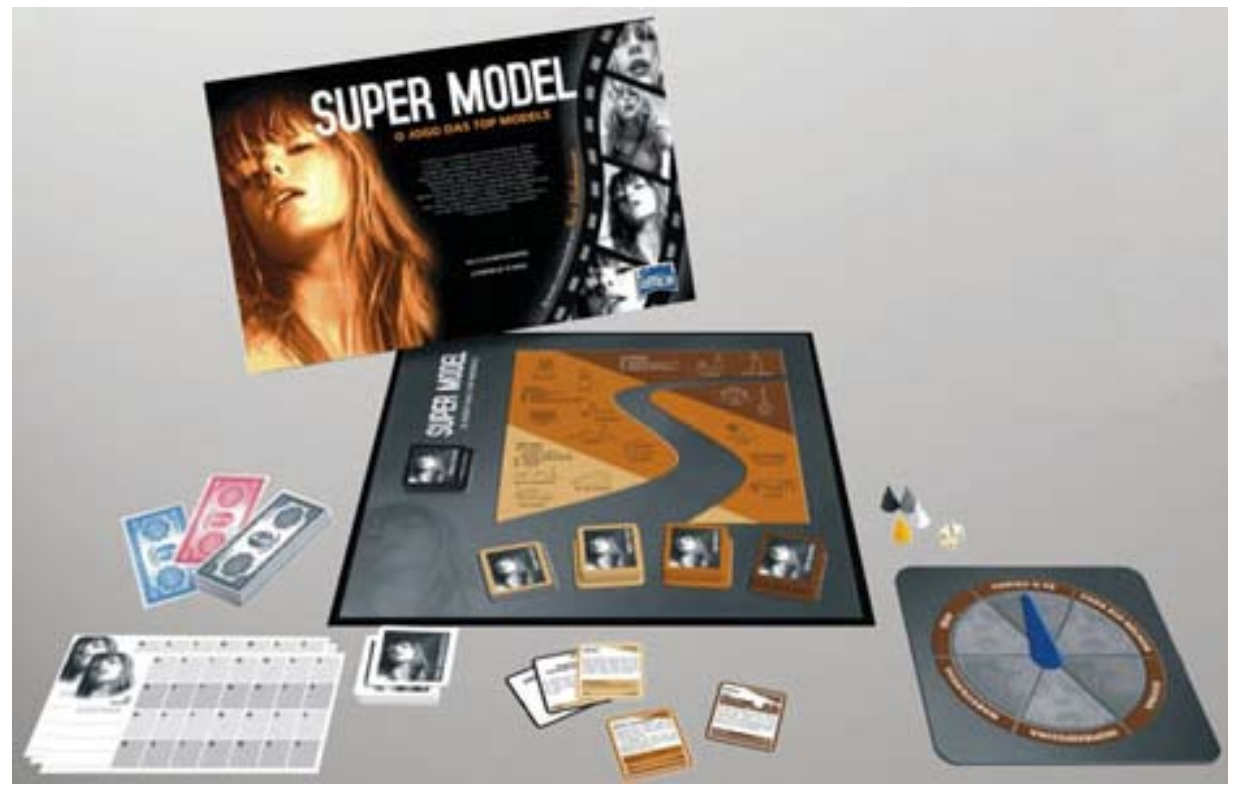

Figura 2. Super Model. Neste jogo, a trajetória de uma modelo de sucesso é apresentada de forma lúdica e informativa e traz o aval da modelo Ana Hickmann. Foi criado para a GMK e lançado no Brasil, em 2004, pela Toyster Brinquedos S.A. O jogo divide-se em três fases caracterizando a carreira de uma modelo do mundo real. Cada uma das fases tem uma mecânica diferente. 


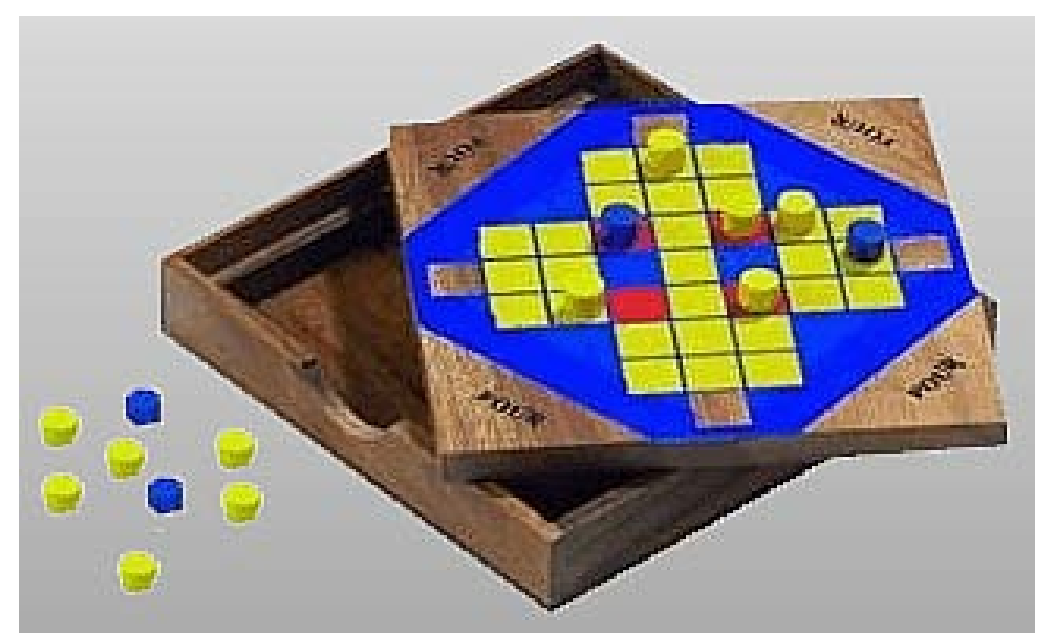

Figura 3. Four. Este passatempo desafia o jogador a reposicionar as quatro peças azuis, levando-as dos quadrados vazios das bordas ao centro do tabuleiro. Este jogo foi criado para a GMK e lançado no mercado europeu pela empresa alemã Philos Games, em 2005.

A automação/ complexidade nos conduz aos jogos de estratégia, uma vez que com as regras automatizadas, jogos muito mais complexos podem ser criados. E acreditamos que, além disso, a automação das regras pode liberar o jogador para executar apenas as ações significativas do jogo, deixando a observância das regras e do estado do jogo por conta do computador. Ou seja, com a automação, o jogador não precisa mais se preocupar em saber de quem é a vez ou mesmo se as regras estão sendo respeitadas, já que estas são controladas pelos algoritmos computacionais.

Entendemos então que apenas a automação/ complexidade seria uma característica que efetivamente diferencia o videogame de seus precursores não eletrônicos. 


\subsection{Da tradução dos termos play e game}

o conceito de jogo é base para o desenvolvimento de discussões relativas ao universo dos jogos e dos videogames. No entanto, antes de tratarmos do conceito de jogo cabe fazer uma observação com relação às diferenças que se apresentam ao traduzirmos as palavras jogo e jogar.

Salen \& Zimmerman (2003:72-73) apontam que os termos play e game podem um conter o outro, dependendo da relação que se estabeleça entre eles. Numa abordagem tipológica, onde a relação entre play e game se dá pela forma que elas aparecem no mundo, play refere-se ao que costumamos chamar de brincadeiras ou passatempos, cujas formas são mais livres, mais frouxas e menos organizadas do que o que chamamos de jogos (game). Num outro sentido, considerando play como a experiência de jogar e, portanto "um elemento crucial dentro do amplo conceito de games, 'play' é de fato um subconjunto de 'game'". Esta outra abordagem é mais conceitual e para os autores "situa play e game dentro do campo de game design" 6 .

Esta distinção entre os termos play e game também é feita por Walther em seu Playing and Gaming. Na tradução elaborada por Luiz Roberto Mendes Gonçalves, os termos play e game são traduzidos por brincar e jogar, respectivamente. Walther

\footnotetext{
${ }^{6}$ Tradução nossa. Do original em inglês: "Although play is a crucial element of the larger concept of games, 'play' is in fact a subset of 'game'. Rather than typological, this pairing of the terms represents a more conceptual approach that situates play and games within the field of game design." (Salen \& Zimmerman, 2003:72-73)
} 
(2005) utiliza-se, logo no início de seu artigo de uma breve definição para distinguir os dois termos:

brincadeiras são um território aberto em que o faz de conta e a construção de mundos são fatores cruciais. Jogos são áreas confinadas que desafiam a interpretação e a otimização de regras e táticas.

Para Walther estas distinções são importantes ao se estudar os jogos de computadores porque a divisão e entrelaçamento de brincadeiras (play) e jogos (game) tocam o conceito de gameplay.

A trama é exatamente equilibrar o brincar e o jogar enquanto se joga. A pessoa deve se ater à distinção inicial (ou seria engolida pelo outro da brincadeira) e precisa aceitar constantemente a organização do jogo, seu padrão de regras. Quando a pessoa desrespeita esse equilíbrio complementar, o fluxo é interrompido.

Um gameplay funciona exatamente para garantir esse fluxo, servindo como matriz potencial da realização temporal de determinadas sequências de jogo.

Para Frasca (1999), a distinção entre play e game e às atividades que relacionamos como brincadeiras e jogos deve-se mais aos seus resultados do que às suas regras, uma vez que, mesmo as brincadeiras das crianças seguem algum tipo de regra. Para explicar essa ideia, Frasca busca apoio nos pensamentos do antropologista Daniel Vidart, que exemplifica que quando uma criança se propõe a brincar de pilotar um avião, ela se comportará como um piloto, não como um médico ou motorista de carro. E que, esta criança que se propôs a regra, embora possa abandoná-la a 
qualquer momento, a aceitará, durante o tempo que durar a brincadeira, da mesma forma que aceitaria as regras de outro jogo qualquer ${ }^{7}$.

Lopes (2005:7) argumenta que, contrariando a percepção popular, tanto o jogo (jogar) quanto a brincadeira (brincar) estão sujeitos a regras. A diferença é que as regras da brincadeira

são determinadas por meio de um processo lúdico de comunicação e através da participação coletiva dos envolvidos, e vão sendo perpetuamente reajustadas, transformadas, e substituídas por outras regras. Isto é assim porque é o acordo - o pacto lúdico - explicita ou implicitamente feito no início do jogo, que posteriormente organiza o jogo ${ }^{8}$.

Por outro lado, o jogo tem suas regras previamente estabelecidas e, por isso, a brincadeira está mais propensa a resultados imprevisíveis, enquanto o jogo, mais focado nos efeitos e resultados finais, é mais previsível. Outra diferença entre jogo e brincadeira apontada por Lopes é com relação ao resultado. Enquanto a brincadeira está sujeita a uma lógica soma não-zero, e reproduz a máxima, se eu

${ }^{7}$ Tradução nossa. Baseado no texto originalmente em inglês: "However, anthropologist Daniel Vidart shows that this assumption is wrong and that plays have also strict rules. He gives the example of a child that pretends to pilot a plane. There is a rule in play: to behave like a pilot, and not like a doctor or a car driver. That rule was proposed and accepted by the same player, and she can drop it whenever she feels like it. While playing, she will accept it, in the same way she would accept a rule in a game". (Vidart, 1995, apud Frasca, 1999).

${ }^{8}$ Tradução nossa. Do original em inglês: "Contrary to popular perception, here play (brincar), like gameplaying (jogar) is subject to rules. However, the rules that govern play are determined through a process of Iudic communication and through the collective participation of those involved, and are perpetually being readjusted, transformed, and substituted by other rules. This is so because of the agreement - the ludic pact - explicitly or implicitly made at the beginning of the game, which subsequently organizes the game". (Lopes, 2005: 7). 
ganho você ganha e se eu perco você perde, o jogo está sujeito a uma lógica soma zero e a máxima que o guia é a do "se eu ganho você perde, e se você ganha, eu perco", o que implica vencedores e perdedores ${ }^{9}$.

Neste mesmo sentido, Andre Lalande propõe dois diferentes significados ao definir jogo $^{10}$ e os diferencia não em função de suas regras, mas de seus resultados. Para Lalande, o jogo (game) define vencedor e perdedor enquanto a brincadeira (play), não ${ }^{11}$.

Frasca (1999) então associa a definição de Lalande aos termos de Caillois, na intenção de prevenir confusões entre os termos:

Paidea é "A profusão de atividade física ou mental que não tem um objetivo útil imediato, nem objetivo definido e cuja única razão de ser está baseada no prazer imediato experimentado pelo jogador".

\footnotetext{
${ }^{9}$ Tradução nossa. Do original em inglês: "Subject to a non-zero sum logic, play reproduces the maxim, whatever I gain you gain, and whatever I lose you lose. Play is focused to a greater extent on the process than on the result, given play's propensity for unpredictable results. On the other hand, game-playing is a ludic situation, predictable and with previously established rules. Gameplaying is focused on final results/ effects and which is guided by the logic of "whatever I win you lose, and whatever you win, I lose", which implies winners and losers". (Lopes, 2005: 7).

${ }^{10}$ Frasca explica que embora Lalande não se refira explicitamente a game e play, pois em francês há uma única palavra para as duas atividades, o autor propõe dois diferentes significados para 'jue'". (Lalande, 1928, apud Frasca, 1999).

${ }^{11}$ Tradução nossa. Baseado no texto originalmente em inglês: "He proposes two different meanings when he defines "jeu" in his Dictionaire Philosophique [Lalande, 1928]. Even though he does not explicitly refers to game and play (just one French word exist for both activities), he differentiates them not because of their rules, but by their result. Games have a result: they define a winner and a Ioser; plays do not". (Lalande, 1928, apud Frasca, 1999).
} 
Ludus é um tipo particular de paidea, definido como uma "atividade organizada sob um sistema de regras que define uma vitória ou uma derrota, um ganho ou uma perda". ${ }^{12}$

Também para Piaget (1964) a ideia de regra ${ }^{13}$ está associada à de vencedor e perdedor. Pois, nas brincadeiras, as crianças não têm por objetivo (e não distinguem) vencedores e perdedores, mas nos jogos que identifica como com regras, isto se verifica ${ }^{14}$. Para Piaget, quando uma criança está imitando, por exemplo, um avião, ela não está seguindo uma regra ao se comportar como se fosse um avião, ele diz que seu comportamento apresenta uma regularidade.

Estas definições nos levam a observar uma relação entre regra e competição, já que os vencedores e perdedores surgem quando se estabelece uma competição. Então, a título de criar um entendimento dentro do universo deste trabalho, utilizaremos os conceitos de Frasca, mas nos referiremos às suas definições utilizando os termos mais usuais de jogos e brincadeiras.

\footnotetext{
12 Tradução nossa. Do original em inglês: "Paidea is "Prodigality of physical or mental activity which has no immediate useful objective, nor defined objective, and whose only reason to be is based in the pleasure experimented by the player". / Ludus is a particular kind of paidea, defined as an "activity organized under a system of rules that defines a victory or a defeat, a gain or a loss." (Frasca, 1999).

${ }^{13}$ Piaget não explicita a diferença que faz entre regra e regularidade.

14 Piaget (1964:145-149), em seu estudo sobre a importância dos jogos e das brincadeiras no desenvolvimento das crianças, dividiu os jogos em três grupos: jogos de exercício, simbólicos e com regras.
} 
Assim, usaremos o termo jogo quando nos referirmos a "atividade organizada sob um sistema de regras que define uma vitória ou uma derrota, um ganho ou uma perda" (Frasca, 1999) e brincadeira ao nos referirmos a atividades "que não têm um objetivo útil imediato, nem objetivo definido e cuja única razão de ser está baseada no prazer imediato experimentado pelo jogador". (Frasca, 1999).

\subsection{0 conceito de jogo}

Não é nosso objetivo fazer um levantamento exaustivo de todas as definições de jogo já formuladas, mas apontar algumas e as formas como foram tratadas ao longo do tempo. Diversos autores já realizaram diferentes levantamentos, privilegiando um aspecto ou outro dos conceitos de jogo.

Salen \& Zimmerman (2003) e Juul (2003) organizaram diversas definições em tabelas buscando levantar as características mais comuns nas definições com que trabalharam.

\subsubsection{Organização dos conceitos de jogo, por Salen \& Zimmerman}

Salen \& Zimmerman (2003) buscaram compreender o que faz de um jogo, jogo e Juul (2003), inspirado em Salen \& Zimmerman buscou criar uma definição de jogo capaz de explicar principalmente os videogames, que o autor prefere chamar de jogos de computador. Salen \& Zimmerman (2003) compararam oito definições e 
criaram uma tabela que sumaria os elementos do jogo, como descritos em cada definição.

As definições usadas pelos autores estão compiladas a seguir:

Parlett Parlett faz uma distinção entre jogos formais e informais. "Um jogo informal é meramente um jogo não dirigido, ou "brincar", como quando crianças ou cachorros brincam desordenadamente" ${ }^{15}$. E então contrasta esta atividade com os jogos formais:

"Um jogo formal tem uma dupla estrutura baseada em fins e meios:

Fins. É uma competição para alcançar um objetivo (o termo grego para game é agôn, significando combate). Apenas um dos combatentes, sejam eles individuais ou times, pode alcançá-lo, alcançando os fins do jogo. Atingir os objetivos é vencer. Um jogo formal, pela definição, tem um vencedor; e vencer é o "fim" do jogo em ambos sentidos da palavra, uma terminação e um objeto.

Meios. Há um conjunto acordado de equipamentos e de "regras" procedimentais pelas quais o equipamento é manipulado para produzir uma situação de vitória ${ }^{16}$.

\footnotetext{
${ }^{15}$ Tradução nossa. Do original em inglês: "An informal game is merly undirected play, or 'playing around,' as when children or puppies play at rough and tumble". (Parlett, 1999:1, apud Salen \& Zimmerman, 2003: 74)

${ }^{16}$ Tradução nossa. Do original em inglês: “A formal game has a twofold structure based on ends and means: Ends. It is a contest to achieve an objective. (The Greek for game is agôn, meaning contest.) Only one of the contenders, be they individuals or teams, can achieve it, since achieving it ends the game. To achieve that object is to win. Hence a formal game, by definition, has a winner; and winning is the "end" of the game in both senses of the word, as termination and as object./ Means. It has an agreed set of equipment and of procedural "rules" by which the equipment is manipulated to produce a winning situation." (Parlett, 1999:1, apud Salen \& Zimmerman, 2003:74
} 
Abt

"Reduzido à sua forma essencial, um jogo é uma atividade entre dois ou mais tomadores de decisão independentes visando atingir seus objetivos dentro de um contexto limitado. Uma definição mais convencional diria que o jogo é um contexto com regras contra adversários tentando alcançar objetivos" ${ }^{17}$.

Huizinga "[0 jogo é] uma atividade livre, conscientemente tomada como "não-séria" e exterior à vida habitual, mas ao mesmo tempo capaz de absorver o jogador de maneira intensa e total. É uma atividade desligada de todo e qualquer interesse material, com a qual não se pode obter qualquer lucro, praticada dentro de limites espaciais e temporais próprios, segundo uma certa ordem e certas regras. Promove a formação de grupos sociais com tendência a rodearem-se de segredos e a sublinharem sua diferença em relação ao resto do mundo por meio de disfarces ou outros meios semelhantes" (Huizinga 2004: 16).

Callois $\quad 0$ jogo é uma atividade

- "Livre: em que jogar não é obrigatório; uma vez que fosse perderia sua qualidade atrativa e alegre enquanto diversão;

- Separada: circunscrita dentro de limites de espaço e tempo, definidos e fixados durante seu avanço;

- Incerta: seu curso não pode ser determinado nem resultados alcançados de antemão, e uma margem para inovações é deixada ao critério da iniciativa do jogador;

- Improdutiva: não gera mercadorias nem bens, nem riqueza, nem novos elementos de nenhum tipo; e exceto pela troca de propriedade entre os jogadores, termina em situação idêntica a que prevalecia no início do jogo;

17 Tradução nossa. Do original em inglês: "Reduced to its formal essence, a game is an activity among two or more independent decision-makers seeking to achieve their objectives in some limiting context. A more conventional definition would say that a game is a context with rules among adversaries trying to win objectives". (Abt, 1970:6, apud Salen \& Zimmerman, 2003: 74). 
- Governada por regras: convencionadas, que suspendem as leis ordinárias, e por um momento estabelece nova legislação, que sozinha basta.

- Faz de conta: acompanhado por uma crença especial de uma segunda realidade ou de uma livre irrealidade, contrária à vida real" ${ }^{18}$.

Suits "Jogar é engaj ar-se em uma atividade dirigida a fazer emergir uma situação específica, usando apenas meios permitidos pelas regras, que proíbem meios mais eficientes em favor de meios menos eficientes e que são aceitas apenas porque tornam a atividade possível" ${ }^{19}$.

-ou mais sucintamente-

“Eu também ofereço a seguinte, mais simples e, por assim dizer, mais portátil da versão anterior: jogar um jogo é o esforço voluntário para superar obstáculos desnecessários" ${ }^{20}$.

${ }^{18}$ Tradução nossa. Do original em inglês: "Caillois also presents a definition of play, describing it as being: 'Free: in which playing is not obligatory; if it were, it would at once lose its attractive and joyous quality as diversion; / Separate: circumscribed within limits of space and time, defined and fixed in advance;/Uncertain: the course of which cannot be determined, nor the result attained beforehand, and some latitude for innovations being left to the player's initiative;/ Unproductive: creating neither goods, nor wealth, nor new elements of any kind; and, except for the exchange of property among the players, ending in a situation identical to that prevailing at the beginning of the game;/Governed by rules: under conventions that suspend ordinary laws, and for the moment establish new legislation, which alone counts;/ Make-believe: accompanied by a special awareness of a second reality or of a free unreality, as against real life'." (Caillois, 2001: 9-10, apud Salen \& Zimmerman, 2003: 76).

19 Tradução nossa. Do original em inglês: "To play a game is to engage in activity directed towards bringing about a specific state of affairs, using only means permitted by rules, where the rules prohibit more efficient in favour of less efficient means, and where such rules are accepted just because they make possible such activity" (Suits, 2005:48-49 e Suits, 1990:41, apud Salen \& Zimmerman, 2003:76).

20 Tradução nossa. Do original em inglês: "To play a game is to engage in activity directed towards bringing about a specific state of affairs, using only means permitted by rules, where the rules prohibit more efficient in favour of less efficient means, and where such rules are accepted just because they make possible such activity" (Suits, 1990:41, apud Salen \& Zimmerman, 2003:76). 
Crawford Salen \& Zimmerman colocam juntos trechos do primeiro capítulo de Crawford, sumariando as quatro qualidades comuns que definem a categoria de jogos: "Representação: Um jogo é um sistema formal fechado que subjetivamente representa um subconjunto da realidade. Por 'fechado' eu quero dizer que o jogo é completo e auto-suficiente enquanto estrutura. 0 modelo de mundo criado pelo jogo é internamente completo; nenhuma referência a agentes fora do jogo precisa ser feita. Por formal eu quero dizer apenas que o jogo tem regras explícitas. Um jogo é uma coleção de peças que interagem umas com as outras, muitas vezes de formas complexas. É um sistema. Um jogo cria uma representação subjetiva e deliberadamente simplificada da realidade emocional.

Interação: A coisa mais fascinante sobre a realidade não é o que é, ou mesmo o que muda, mas como ela muda, a intrincada teia de causa e efeito pela qual todas as coisas estão interconectadas. A única forma de representar esta teia é permitir que o público explore cada aperto de uma situação, deixar que eles gerem causa e observem os ef eitos. Jogos proveem este elemento interativo, e é um fator decisivo de seu apelo.

Conflito: Um terceiro elemento que aparece nos jogos é o conflito. 0 conflito ocorre naturalmente da interação no jogo. 0 jogador está ativamente perseguindo algum objetivo. Obstáculos evitam que ele conquiste facilmente o seu objetivo. Conflito é um elemento intrínseco de todos os jogos. Pode ser direto ou indireto, violento ou não-violento, mas está sempre presente em cada jogo.

Segurança: Conflito implica perigo; perigo significa risco de dano; dano é indesejável. Entretanto, um jogo é um artifício que provê as experiências psicológicas ao mesmo tempo que exclui suas realizações físicas. Em resumo, um jogo é um modo seguro de experimentar a realidade. Mais precisamente, 
os resultados de um jogo são sempre menos severos do que as situações que servem de modelo para os jogos". ${ }^{21}$

Costikyan "Um jogo é uma forma de arte, na qual os participantes, chamados de jogadores, tomam decisões para gerenciar recursos por meio das peças do jogo na perseguição de um objetivo" ${ }^{22}$.

Avedon | "Jogos são um exercício de sistema de controle voluntário, em que há uma Sutton-Smith competição de poderes, confinados por regras a fim de produzir um resultado desequilibrado" 23 .

${ }^{21}$ Tradução nossa. Do original em inglês: "We have pulled together excerpts from the first chapter of his book, where he summarizes these four qualities: / Representation: A game is a closed formal system that subjectively represents a subset of reality. By "closed" I mean that the game is complete and self-sufficient as a structure. The model world created by the game is internally complete; no reference need be made to agents outside of the game. By formal I mean only that the game has explicit rules. A game's a collection of parts which interact with each other, often in complex ways. It is a system. A game creates a subjective and deliberately simplified representation of emotional reality. / Interaction: The most fascinating thing about reality is not that it is, or even that it changes, but how it changes, the intricate webwork of cause and effect by which all things are tied together. The only way to properly represent this webwork is to allow the audience to explore its nooks and crannies, to let them generate causes and observe effects. Games provide this interactive element, and it is a crucial factor in their appeal. / Conflict: A third element appearing in all games is conflict. Conflict arises naturally from the interaction in a game. The player is actively pursuing some goal. Obstacles prevent him from easily achieving this goal. Conflict is an intrinsic element of all games. It can be direct or indirect, violent or nonviolent, but it is always present in every game. I Safety: Conflict implies danger; danger means risk of harm; harm is undesirable. Therefore, a game is an artifice for providing the psychological experiences of conflict and danger while excluding their physical realizations. In short, a game is a safe way to experience reality. More accurately, the results of a game are always less harsh than the situations the game models". (Crawford, 1984:7-14, apud Salen \& Zimmerman, 2003: 77)

${ }^{22}$ Tradução nossa. Do original em inglês: "A game is a form of art in which participants, termed players, make decisions in order to manage resources through game tokens in the pursuit of a goal." (Costikyan, 1994). 
A tabela a seguir, elaborada por Salen \& Zimmerman, parte das definições acima, sumariando os elementos do jogo de cada uma delas. Para os autores (2003:79-80) a simplificação dos conceitos, por meio de sua organização numa tabela, acarreta perda do contexto e das sutilezas das idéias de cada autor, no entanto, permite alguns resultados comparativos interessantes, como a identificação das regras como elemento-chave nas definições de todos os autores, exceto Costikyan.

Os autores observam ainda que

Embora 10 dos 15 elementos sejam compartilhados por mais de um autor, fora as regras e objetivos, não há acordo majoritário sobre qualquer um deles ${ }^{24}$.

E que nem todos os elementos deveriam ser inclusos em uma definição de jogo, ou por não se aplicarem a todos os jogos, ou por descreverem mais efeitos da atividade de jogar do que o jogo em si, ou ainda, por não ajudarem a definir a atividade do jogo pelo fato de estarem presentes também em outros meios.

Alguns elementos, como os jogos serem voluntários ou ineficientes, parecem não se aplicar a todos os jogos. Outros, como o fato de que os jogos criam grupos sociais, descrevem efeitos dos jogos em vez de jogos propriamente ditos. Outros elementos ainda, tais como a qualidade representacional ou de

\footnotetext{
${ }^{23}$ Tradução nossa. Do original em inglês: "Games are an exercise of voluntary control systems, in which there is a contest between powers, confined by rules in order to produce a disequilibrial outcome". (Avedon \& Sutton-Smith, 1971:78, apud Salen \& Zimmerman, 2003:74).

${ }^{24}$ Tradução nossa. Do original em inglês: "Although 10 of the 15 elements are shared by more than one author, apart from rules and goals, there is no majority agreement on any one of them". (Salen \& Zimmerman, 2003: 79).
} 
faz de conta dos jogos, aparecem em muitos outros meios e não ajudam a diferenciar jogos de outros tipos concebidos de experiências ${ }^{25}$.

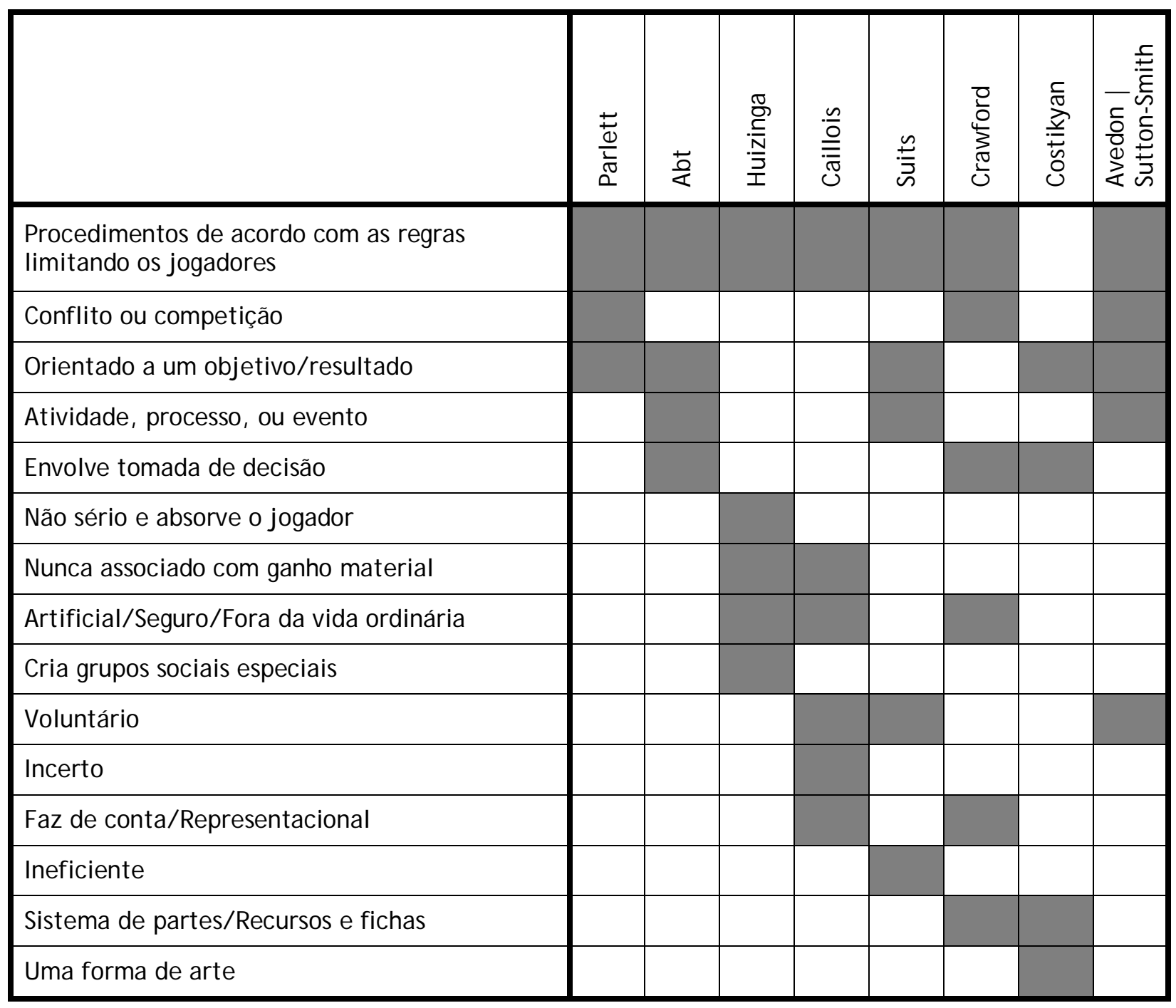

Tabela 1. Comparação dos elementos de jogo (traduzida de Salen \& Zimmerman, 2003: 79)

25 Tradução nossa. Do original em inglês: "Some elements, such as games being voluntary or inefficient, do not seem to apply to all games. Others, such as the fact that games create social groups, describe the effects of games rather than games themselves. Still other elements, such as the representational or make-believe quality of games, appear in many other media and do not help differentiate games from other kinds of designed experiences". (Salen \& Zimmerman, 2003: 79-80). 
Da observação desta tabela e de suas considerações sobre os elementos, os autores propõem sua definição de jogo: "um jogo é um sistema em que os jogadores se envolvem em um conflito artificial, definido por regras, que resulta em um produto quantificável”26. À definição seguem-se as explicações sobre as ideias primárias nela contidas.

Por sistema os autores compreendem "um conjunto de partes que juntas formam um todo complexo" ${ }^{27}$. Um jogo, enquanto um sistema,

proporciona contextos de interação, que podem ser espaços, objetos e comportamentos que os jogadores exploram, manipulam e habitam. Os sistemas vêm a nós em muitas formas, de sistemas mecânicos e matemáticos a conceituais e culturais. Um dos desafios da nossa discussão atual é a de reconhecer as muitas maneiras que um jogo pode ser enquadrado como um sistema. Xadrez, por exemplo, poderia ser pensado como um sistema de estratégia matemática. Poderia também ser pensado como um sistema de interação social entre os dois jogadores, ou um sistema que simula abstratamente uma guerra. ${ }^{28}$

\footnotetext{
${ }^{26}$ Tradução nossa. Do original em inglês: "A game is a system in which players engage in an artificial conflict, defined by rules, that results in a quantifiable outcome". (Salen \& Zimmerman, 2003: 80).

27 Tradução nossa. Do original em inglês: "a set of parts that together form a complex whole". (Salen \& Zimmerman, 2003:50).

${ }^{28}$ Tradução nossa. Do original em inglês: “As systems, games provide contexts for interaction, which can be spaces, objects, and behaviors that players explore, manipulate, and inhabit. Systems come to us in many forms, from mechanical and mathematical systems to conceptual and cultural ones. One of the challenges of our current discussion is to recognize the many ways that a game can be framed as a system. Chess, for example, could be thought of as a strategic mathematical system. It could also be thought of as a system of social interaction between two players, or a system that abstractly simulates war". (Salen \& Zimmerman, 2003:50).
} 
Quando se referem a jogadores pensam nos participantes ativos do jogo, que interagem com o sistema de jogo.

A artificialidade é, para os autores, um dos traços distintivos do conceito de jogo. "Os jogos mantêm uma fronteira entre a chamada 'vida real', no tempo e espaço. Embora, obviamente, os jogos ocorram no mundo real, a artificialidade é um dos seus traços distintivos" ${ }^{29}$.

Com relação ao conflito, os autores consideram que "todos os jogos incorporam uma disputa de poderes" ${ }^{30}$. Esta disputa pode incluir tanto a cooperação quanto a competição e é um dos pontos centrais dos jogos.

As regras, para Salen e Zimmerman, são uma parte crucial de jogos, que "proveem a estrutura a partir da qual o jogo emerge, pela delimitação do que o jogador pode e não pode fazer" ${ }^{31}$.

E com relação aos resultados quantificáveis, os autores argumentam:

\footnotetext{
${ }^{29}$ Tradução nossa. Do original em inglês: “Artificial: Games maintain a boundary from so-called "real life" in both time and space. Although games obviously occur within the real world, artificiality is one of their defining features". (Salen \& Zimmerman, 2003:80).

30 Tradução nossa. Do original em inglês: "Conflict: All games embody a contest of powers. The contest can take many forms, from cooperation to competition, from solo conflict with a game system to multiplayer social conflict. Conflict is central to games". (Salen \& Zimmerman, 2003:80).

${ }^{31}$ Tradução nossa. Do original em inglês: “Rules: We concur with the authors that rules are a crucial part of games. Rules provide the structure out of which play emerges, by delimiting what the player can and cannot do". (Salen \& Zimmerman, 2003:80).
} 
Os jogos têm um objetivo ou resultado quantificável. Na conclusão de um jogo, um jogador ganhou, perdeu ou recebeu algum tipo de pontuação numérica. Um resultado quantificável é o que normalmente distingue um jogo de desempenhar atividades menos formais ${ }^{32}$.

Analisando a tabela proposta por Salen \& Zimmerman, notamos que quando os autores assinalaram as características relativas à definição dada por Huizinga, 0 fato do jogo ser voluntário não é citado. Isto porque os autores se utilizam de um trecho onde Huizinga se propõe a tentar resumir as características formais do jogo. Características estas que ele vem discutindo em páginas anteriores e, embora 0 fato de ser uma atividade voluntária, não esteja presente neste trecho, sua importância já havia sido anteriormente discutida:

Antes de mais nada, o jogo é uma atividade voluntária. Sujeito a ordens, deixa de ser jogo, podendo no máximo ser uma imitação forçada. (Huizinga, 1938: 9)

Além disso, mais à frente em seu livro, ao delimitar a ideia que a palavra jogo exprime, Huizinga toma como ponto de partida a noção expressa pela palavra na maior parte das línguas europeias e que pode ser assim definida:

O jogo é uma atividade ou ocupação voluntária, exercida dentro de certos e determinados limites de tempo e espaço, segundo regras livremente consentidas, mas absolutamente obrigatórias, dotado de um fim em si

\footnotetext{
32 Tradução nossa. Do original em inglês: “Quantifiable outcome: Games have a quantifiable goal or outcome. At the conclusion of a game, a player has either won or lost or received some kind of numerical score. A quantifiable outcome is what usually distinguishes a game from less formal play activities". (Salen \& Zimmerman, 2003:80).
} 
mesmo, acompanhado de um sentimento de tensão e alegria e de uma consciência de ser diferente da "vida cotidiana". (Huizinga, 1938:33)

Poderíamos então, a título de facilitar o entendimento das ideias apresentadas a seguir, dizer que a definição de Huizinga, utilizada por Salen e Zimmerman, referese às características formais do jogo e a que apresentamos acima, como referente ao conceito de jogo, mais propriamente. Nesta definição de jogo, Huizinga busca uma noção que seja capaz de abranger tudo o que entendemos por jogo, quer nos refiramos àqueles praticados pelas crianças, pelos adultos ou mesmo pelos animais; compreende desde as brincadeiras (play) aos jogos mais estruturados (game), sejam eles de que natureza forem, dos jogos de rua ou tabuleiro aos videogames.

Pensamos que os autores deveriam considerar conjuntamente as duas definições de Huizinga, tanto a que define as características formais do jogo quanto a que define o conceito de jogo, visto que se esta última apenas substituísse a primeira (utilizada pelos autores), algumas das características do jogo que são importantes para Huizinga acabariam por não serem levadas em conta. No entanto, a característica do jogo ser uma atividade voluntária não pode ser desprezada.

Não concordamos com os autores quando dizem que "alguns elementos, como os jogos serem voluntários ou ineficientes, parecem não se aplicar a todos os jogos" (Salen \& Zimmerman, 2003:79-80, opus cited), pois consideramos importante esta referência ao jogo como uma atividade voluntária. Acreditamos que, em parte, é 
nesta característica que reside o prazer de jogar, no fato do jogo ser uma atividade a que nos entregamos espontaneamente, e não por dever ou obrigação.

A consideração conjunta destas duas definições propostas por Huizinga implicaria uma pequena modificação na tabela construída por Salen $\&$ Zimmerman, pois ao levarmos em conta que Huizinga considera também como característica do jogo 0 fato deste ser uma atividade voluntária, podemos observar que este elemento também seria passível de destaque. Um destaque semelhante ao que os autores dão aos objetivos: "fora as regras e objetivos, não há acordo majoritário sobre qualquer um deles" (Salen \& Zimmerman, 2003:79, ibid).

Os objetivos são citados por cinco dos oito autores analisados e, com esta alteração na tabela, o fato do jogo ser voluntário seria uma característica compartilhada por quatro dos autores e deixaria de se configurar como mais uma das muitas que são compartilhadas por dois ou três autores apenas.

Nesta organização proposta por Salen \& Zimmerman, mesmo que não consideremos a alteração que sugerimos ser necessária, observamos que os autores buscaram elencar características que sejam essenciais e necessárias para fazer de alguma coisa um jogo. É este o mesmo intuito de Juul, ao inspirar-se nos autores para elaborar sua própria tabela, organizando os conceitos dos quais derivará sua definição de jogo. 


\subsubsection{Organização dos conceitos de jogo, por J esper J uul}

Ao buscar criar uma definição de jogo que explique os jogos por computador e os que estão na fronteira entre ser ou não jogos, Juul (2003) analisa sete definições propostas por outros autores, levando em conta que algumas delas observam o jogo como tal e outras focam a atividade de jogar.

0 autor observa também que alguns aspectos são tratados pelos diferentes autores de formas também diferentes.

Quando um escritor menciona objetivos e um outro menciona conflito, é possível traduzir entre eles: A noção de conflito implica (conflitantes) objetivos; a noção de objetivos parece implicar a possibilidade de não atingir o objetivo, e assim também um conflito ${ }^{33}$.

As definições dos autores com as quais J uul trabalha são:

J ohan Huizinga

“...uma atividade livre, conscientemente tomada como "não-séria" (1950, p.13) e exterior à vida habitual, mas ao mesmo tempo capaz de absorver o jogador de maneira intensa e total. É uma atividade desligada de todo e qualquer interesse material, com a qual não se pode obter qualquer lucro, praticada dentro de limites espaciais e temporais próprios, segundo uma certa ordem e certas regras. Promove a formação de grupos sociais com tendência a rodearem-se de segredos e a sublinharem sua diferença em relação ao resto do

\footnotetext{
33 Tradução nossa. Do original em inglês: "When one writer mentions goals and another mentions conflict, it is possible to translate between them: The notion of conflict entails (conflicting) goals; the notion of goals seems to entail the possibility of not reaching the goal, and thereby also a conflict". (J uul, 2003)
} 
mundo por meio de disfarces ou outros meios semelhantes ${ }^{34 "}$.

Roger Caillois

(1958, p. 10-11)

Bernard Suits

(1978, p. 34)

Avedon \& Sutton-

Smith $(1981$, p.7) “[o jogo] é uma atividade que é essencialmente: livre (voluntária), separada (no tempo e espaço), incerta, improdutiva, governada por regras, fictícia (faz de conta)"

"J ogar um jogo é se engajar em uma atividade dirigida para causar um estado específico de ocorrências, usando somente meios permitidos por regras, onde as regras proíbem meios mais eficientes em favor de meios menos eficientes, e onde tais regras são aceitas apenas porque elas tornam possível tal atividade".

"No seu nível mais elementar, então, podemos definir jogo como um exercício de sistemas de controle voluntário, nos quais há uma oposição entre forças, confinado por um procedimento e regras a fim de produzir um resultado não estável".

Chris Crawford ${ }^{35} \quad$ "Eu percebo quatro fatores comuns: representação [um sistema (1981, Cap. 2) formal fechado que subjetivamente representa um recorte da realidade], interação, conflito, e segurança [o resultado do jogo é sempre menos severo que as situações que o jogo modela]".

David Kelley (1988, p.50)
“Um jogo é uma forma de recreação constituída por um conjunto de regras que especificam objeto (objetivo) a ser almejado e os meios permissíveis de consegui-lo".

\footnotetext{
34 Para a transcrição das definições utilizadas por J uul nos utilizamos das traduções feitas por Ranhel (2009: 10)

${ }^{35} \mathrm{O}$ que J uul cita aqui como sendo uma publicação de 1981 aparece em sua bibliografia como 1982 e refere-se ao livro The Art of Computer Game Design, publicado por Osborne/ McGraw-Hill, em 1984.
} 
Salen \& Zimmerman "Um jogo é um sistema no qual jogadores engajam em um conflito (2003, p.96) artificial, definido por regras, que resultam em um resultado quantificável".

Para o autor, uma boa definição de jogo deve descrever três coisas:

1) Os tipos de sistemas criados pelas regras de um jogo (o jogo). 2) A relação entre 0 jogo e 0 jogador do jogo (o jogador). 3) A relação entre 0 jogar 0 jogo e o resto do mundo (o mundo) ${ }^{36}$.

Em função disto, o autor organiza inicialmente todos os pontos das definições em dez categorias, relacionando-as aos níveis de relação que o jogo estabelece.

Desta organização inicial em dez categorias, Juul vai reorganizá-las para chegar às seis características que considera essenciais para que algo possa ser considerado um jogo, que se reúnem na definição de jogo criada pelo autor.

Um jogo é um sistema formal baseado em regras com resultado variável e quantificável, onde a diferentes resultados são atribuídos valores diferentes, o jogador exerce esforço no sentido de influenciar o resultado, 0 jogador sente-se vinculado ao resultado, e as consequências da atividade são opcionais e negociáveis ${ }^{37}$.

\footnotetext{
${ }^{36}$ Tradução nossa. Do original em inglês: "So let's assume that a good game definition should describe three things: 1) The kinds of systems set up by the rules of a game (the game). 2) The relation between the game and the player of the game (the player). 3) The relation between the playing of the game and the rest of the world (the world)". (J uul, 2003)

37 Tradução nossa. Do original em inglês: "A game is a rule-based formal system with a variable and quantifiable outcome, where different outcomes are assigned different values, the player exerts effort in order to influence the outcome, the player feels attached to the outcome, and the consequences of the activity are optional and negotiable". (J uul, 2003)
} 


\begin{tabular}{|c|c|c|c|c|}
\hline & $\begin{array}{l}\text { O jogo } \\
\text { como } \\
\text { sistema } \\
\text { formal. }\end{array}$ & $\begin{array}{c}0 \\
\text { jogador } \\
\text { e o jogo }\end{array}$ & $\begin{array}{l}0 \text { jogo } \\
\text { e o resto } \\
\text { do mundo }\end{array}$ & Outros \\
\hline $\begin{array}{l}\text { Regras } \\
\text { Regras fixas (Huizinga) } \\
\text { Regras (Caillois) } \\
\text { Regras (Suits) } \\
\text { Procedimentos \& regras (Avedon \& Sutton-Smith) } \\
\text { Sistema formal (Crawford) } \\
\text { Regras (Kelley) } \\
\text { Regras (Salen \& Zimmerman) }\end{array}$ & & & & \\
\hline $\begin{array}{l}\text { Resultado } \\
\text { Incerto (Caillois) } \\
\text { Resultado desequilibrado (Avedon \& Suton-Smith) } \\
\text { Mudança de curso (Kelley) } \\
\text { Resultado quantificável (Salen \& Zimmerman) }\end{array}$ & & & & \\
\hline $\begin{array}{l}\text { "Objetivos" } \\
\text { Recurso sobre um estado de coisas (Suits) } \\
\text { Oposição (Avedon \& Sutton-Smith) } \\
\text { Conflito (Crawford) } \\
\text { Objeto a ser obtido (Kelley) }\end{array}$ & & & & \\
\hline $\begin{array}{l}\text { Interação } \\
\text { Interação (Crawford) }\end{array}$ & & & & \\
\hline $\begin{array}{l}\text { Objetivos, regras, e o mundo } \\
\text { Conflito artificial (Zimmerman \& Salen) }\end{array}$ & & & & \\
\hline $\begin{array}{l}\text { "Separado" } \\
\text { Fora da vida ordinária / limites próprios (Huizinga) } \\
\text { Separado (Caillois) } \\
\text { Sem interesse material (Huizinga) } \\
\text { Improdutivo (Caillois) }\end{array}$ & & & & \\
\hline $\begin{array}{l}\text { "Não trabalho" } \\
\text { Livre / voluntário (Caillois) } \\
\text { Sistema de controle voluntário (Avedon \& Sutton- } \\
\text { Smith) } \\
\text { Recreação (Kelley) }\end{array}$ & & & & \\
\hline $\begin{array}{l}\text { Meios menos eficientes } \\
\text { Meios menos eficientes (Suits) }\end{array}$ & & & & \\
\hline $\begin{array}{l}\text { Grupos sociais } \\
\text { Promove agrupamentos sociais (Huizinga) }\end{array}$ & & & & \\
\hline $\begin{array}{l}\text { Ficção } \\
\text { Representação (Crawford) } \\
\text { Faz de conta (Caillois) } \\
\text { Seguro (Crawford) }\end{array}$ & & & & \\
\hline
\end{tabular}

Tabela 2. Comparações das definições de jogo (traduzida de J uul, 2003:32-33) 
A tabela abaixo demonstra a relação de cada um dos pontos da definição com as relações que se estabelecem entre 0 jogo, 0 jogador e 0 mundo, que 0 autor entende enquanto níveis.

\begin{tabular}{|l|l|l|l|}
\hline & $\begin{array}{c}\text { 0 jogo como } \\
\text { sistema formal }\end{array}$ & $\begin{array}{c}\text { 0 jogador } \\
\text { e o jogo }\end{array}$ & $\begin{array}{c}\text { 0 jogo e } \\
\text { o resto do } \\
\text { mundo }\end{array}$ \\
\hline 1. Regras & & & \\
\hline 2. Resultado variável e quantificável & & & \\
\hline 3. Valorização do resultado & & & \\
\hline 4. Esforço do jogador & & & \\
\hline 5. Jogador vinculado ao resultado & & & \\
\hline 6. Consequências negociáveis & & & \\
\hline
\end{tabular}

Tabela 3. O modelo clássico de jogo, o jogo, o jogador e o mundo (traduzida de J uul, 2003:37)

Cada um dos seis pontos da definição é discutido em separado. Sobre regras, J uul afirma que estas precisam ser bem definidas o suficiente para que não haja a necessidade de se argumentar sobre elas a cada partida ou o suficiente para serem programadas em um computador.

As considerações sobre resultado variável e quantificável vão no sentido de que não só "as regras do jogo devem fornecer diferentes resultados possíveis" ${ }^{38}$ mas que

\footnotetext{
${ }^{38}$ Tradução nossa. Do original em inglês: "For something to work as a game, the rules of the game must provide different possible outcomes". (J uul, 2003)
} 
o jogo também precisa se adaptar às habilidades dos jogadores, garantindo um certo grau de desafio que possibilite o progresso e envolvimento do jogador.

Ao analisar a relação entre o objetivo e o jogador, J uul estabelece uma divisão dos objetivos em três componentes: a valorização dos resultados, o esforço do jogador e o vínculo que o jogador estabelece com o resultado alcançado.

Nas palavras do próprio J uul, valorização dos resultados, significa, simplesmente, "que alguns dos possíveis resultados do jogo são melhores que outros" ${ }^{39}$ e que "a diferentes resultados potenciais do jogo são atribuídos valores diferentes, alguns positivos, alguns negativos" ${ }^{40}$. 0 autor refere-se aqui às regras que garantem a condição de vitória e/ ou aos melhores desempenhos no cumprimento de certos quesitos.

O esforço do jogador diz respeito ao investimento de esforço que o jogador precisa fazer no sentido de influenciar o resultado e superar o desafio que o jogo the apresenta.

\footnotetext{
${ }^{39}$ Tradução nossa. Do original em inglês: "This simply means that some of the possible outcomes of the game are better than others". (J uul, 2003)

${ }^{40}$ Tradução nossa. Do original em inglês: “3) Value assigned to possible outcomes: That the different potential outcomes of the game are assigned different values, some being positive, some being negative.". (J uul, 2003)
} 
O vínculo do jogador ao resultado é uma característica psicológica do jogo e não está relacionada apenas ao esforço do jogador. Diz respeito ao sentimento de felicidade quando o jogador alcança um resultado positivo e um sentimento de infelicidade quando o resultado é negativo. Este sentimento pode ser percebido também em jogos de pura sorte, que independem do esforço do jogador.

Inversamente à subdivisão de um elemento em outros três, Juul agrupa dois elementos que ele inicialmente listara como distintos: o fato do jogo ser "separado" e considerado "não-trabalho", em um único: consequências negociáveis. Sua discussão parte da definição de Caillois, para quem os jogos são tanto separados no tempo e no espaço do resto do mundo quanto improdutivos. Com relação ao fato de ser separado, J uul argumenta que é possível jogar xadrez por correspondência, caso em que o jogo sobrepõe a vida cotidiana, tanto no sentido de que o intervalo de tempo do jogo se sobrepõe a uma parte da vida não-jogo, quanto no sentido de que é possível considerar o movimento que se quer fazer no jogo enquanto às voltas com os negócios diários. Do mesmo modo, muitos jogos de estratégia baseados em rede se estendem ao longo de meses ou mesmo anos ${ }^{41}$.

E com relação a ser improdutivo, Juul pontua que Caillois sugere que o jogo não produz nada e questiona que isto se apresenta como um problema, do ponto de

\footnotetext{
${ }^{41}$ Tradução nossa. Do original em inglês: “It is after all possible to play chess by mail, in which case the game overlaps daily life, both in the sense that the time span of the game overlaps a non-game part of life, and in the sense that it is possible to consider the moves one wants to play while going around one's daily business. Likewise, many net-based strategy games stretch over months or even years". (J uul, 2003)
} 
vista econômico pelo fato do jogo ser, de fato, uma grande indústria. E porque, a rigor, pode-se apostar em qualquer jogo e existem pessoas que ganham a vida jogando, 0 autor sugere que

os jogos sejam caracterizados por serem atividades com consequências negociáveis: Um específico jogar um jogo pode ter determinadas consequências, mas um jogo é um jogo, porque as consequências são opcionalmente aceitas sobre uma base por-jogo. Que os jogos exercem um grau de separação do resto do mundo segue-se de suas consequências serem negociáveis ${ }^{42}$. (J uul, 2003)

Assim, consequências negociáveis referem-se ao fato do mesmo jogo (ou conjunto de regras) poder ser jogado com ou sem consequências na vida real. J uul pondera que temos a tendência a pensar no jogo como algo sem consequências graves, mas estas podem ser alteradas em função das atribuições negociadas jogo a jogo, pessoa a pessoa. O autor lembra ainda que "o único caminho para um jogo ter consequências negociáveis é que as operações e os movimentos necessários para jogar sejam predominantemente inofensivos" ${ }^{43}$.

Diferentemente de Juul, entendemos que a colocação de Caillois de que o jogo não produz nada, refere-se a atividade de jogar em si, ao fato de que, fora as possíveis

\footnotetext{
${ }^{42}$ Tradução nossa. Do original em inglês: "A game is a rule-based formal system with a variable and quantifiable outcome, where different outcomes are assigned different values, the player exerts effort in order to influence the outcome, the player feels attached to the outcome, and the consequences of the activity are optional and negotiable". (J uul, 2003)

${ }^{43}$ Tradução nossa. Do original em inglês: "The only way for a game to have negotiable consequences is to have the operations and moves needed to play the game are predominantly harmless". (J uul, 2003)
} 
trocas que possam ocorrer entre os jogadores, o jogo terminará da mesma forma como começou, ninguém terá mais ou menos do que no momento em que o jogo foi iniciado. Quando nos referimos a jogos, pensamos neles como uma atividade lúdica, cujo objetivo principal é a diversão, o entretenimento e o prazer. Apostas e situações de pessoas que ganham a vida jogando são derivações e desvios deste objetivo principal, de diversão, entretenimento e prazer, a que os jogos se propõem. E nem mesmo estamos levando em consideração a eventual utilização da capacidade cognitiva, nem o exercitar da memória que um jogo pode proporcionar.

Mas o intuito de Juul, neste artigo, mais do que criar uma definição de jogo, sua intenção é explicar os jogos por computador e os que estão na fronteira entre ser ou não jogos. Esta ideia é apresentada em um diagrama com dois círculos concêntricos onde tudo que tiver os seis atributos necessários para algo ser considerado um jogo estará no círculo interno. No círculo externo estão as atividades fronteiriças, que são como-jogos ou quase-jogos. Tudo o que não é jogo fica fora dos círculos. As setas indicam a remoção de um dado atributo, que o autor indica entre parenteses de qual se trata.

O diagrama apresentado deixa clara a definição de jogo de J uul. A discussão sobre 0 que é jogo e o que fica fora desta categoria é possível ser percebida tanto por uma análise do diagrama quanto com base em suas explicações que situam jogos como sendo fronteiriços ou como não-jogos. 


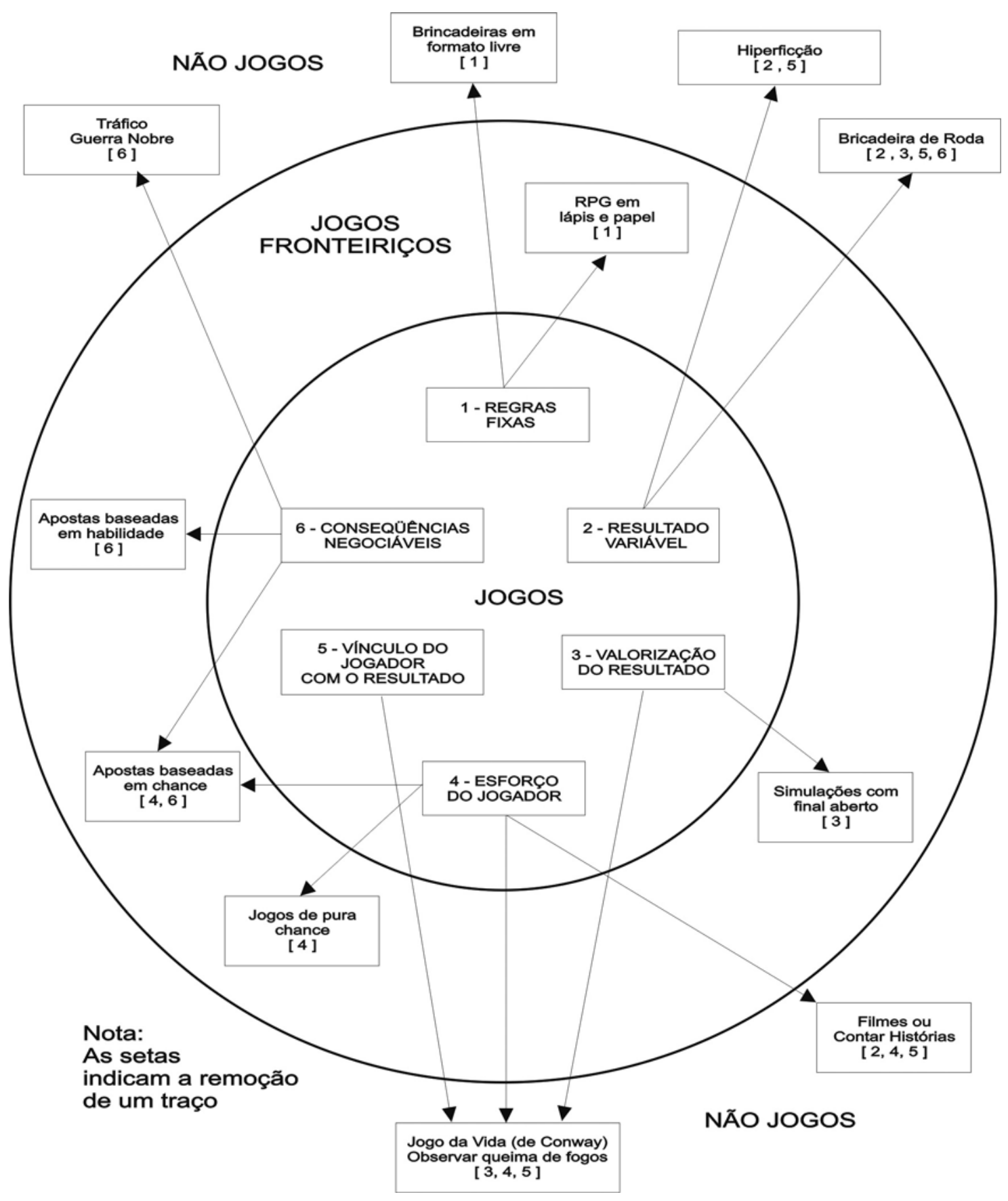

Gráfico 1. Diagrama traduzido de J uul (2003) 
No entanto, o que não é possível entender é a lógica que distingue quase-jogos (jogos fronteiriços) de não-jogos. Tanto em uma quanto outra das esferas nãocentrais (a dos jogos) encontramos atividades lúdicas que não apresentam apenas uma das características. Vejamos o exemplo dos RPG em lápis e papel e das brincadeiras de formato livre. Ambas não possuem regras fixas, mas a primeira foi situada por Juul como sendo um jogo fronteiriço, um quase-jogo, enquanto as brincadeiras são colocadas como não-jogos.

Mesmo que dirijamos nossas observações para os níveis a que pertencem cada uma das características, ou seja, para as relações que se estabelecem entre o jogo ele mesmo, entre o ojogo e o jogador e entre o jogo e o resto do mundo, ainda assim não encontramos consistência nessa distinção.

Ranhel (2009:14-16) analisa ainda outras situações que acredita que depõem contra a definição de J uul. O primeiro exemplo nos sugere conjecturar sobre uma partida de xadrez em que um jogador distraído faz uma movimentação equivocada e seu oponente Ihe permite voltar a jogada. Ranhel argumenta

Pela definição de Juul, nessas circunstâncias, o xadrez seria classificado como um quase-jogo ou um não-jogo, afinal, neste contexto ele está deixando de ter regras fixas. No entanto, A pode ter feito isso para permitir que $\mathbf{B}$ exerça mais adequadamente seu esforço (atributo 4 da definição de J uul); e quanto maior o esforço de $\mathbf{B}$, mais merecida a vitória de $\mathbf{A}$, ou seja, ela está valorizando sua vitória (atributo 3 ) ao permitir, contra as regras do xadrez, que seu adversário se torne mais forte ao corrigir suas desatenções. Talvez A não fizesse o mesmo se sentisse que B fez tal movimento por 
descaso e, assim, ele seria um desmancha-prazeres e estaria desvalorizando a vitória dela.

Outra situação apresentada por Ranhel é a de uma partida de vólei de praia em que C e D jogam contra E e F e que, um deles escorrega ao sacar, provocando uma situação hilária. Ranhel discute a situação imaginando que seja um jogo por diversão, então os adversários podem permitir que o saque seja feito novamente. Ranhel lembra que

Repetir a jogada é um não valeu que não existe em nenhuma regra de qualquer jogo sério, mas que acontece por cavalheirismo ou por empatia dos jogadores em certas situações. Os adversários sabem (ou esperam) que, se 0 mesmo Ihes ocorresse, contariam com tratamento similar.

Para tal situação Ranhel utiliza argumentos semelhantes aos apresentados acima, e ainda

podem ser vistas como um caso de consequências negociáveis (atributo 6), relacionadas com a finalidade do jogo, ou seja, se é paidia, pura diversão, não há necessidade de levá-lo a sério. Nesse caso, o vólei de praia deixaria de ser jogo e passaria a ser quase-jogo, ou não-jogo porque, a exemplo das brincadeiras de criança, um jogo nessa situação apresenta casos em que as regras (atributo 1) estão em constante negociação.

Mas consideremos uma situação semelhante em uma partida profissional, disputada dentro de um campeonato. Esta atitude do "não valeu", mais do que um caso de consequências negociáveis, pode ser considerada como fair play ou jogo limpo. 0 fair play é uma forma elegante de retomar as regras do jogo, que foram desviadas por uma situação anômala, excepcional, e que retoma o seu rumo. 0 futebol nos 
oferece um bom exemplo disso. 0 jogo é pelo campeonato holandês entre o Ajax e o ADO Den Haag. Um jogador do Ajax sofre uma falta e fica no chão com dores. Como costuma acontecer nestes casos, a equipe adversária, o ADO Den Haag, põe a bola para fora para que o jogador possa ser atendido. Após o atendimento o jogador do Ajax, na intenção de devolver a bola, acaba, sem querer, fazendo um gol. Embora essa não fosse a intenção do jogador, o gol foi validado pelo juiz, que, inclusive, não poderia agir diferente. Ao reiniciar o jogo no meio do campo, os jogadores do Ajax não se movimentaram, permitindo assim que o ADO Den Haag também marcasse um gol, revertendo a situação daquele gol que "não valeu" naquela situação.

Podemos ver, que mesmo em disputas profissionais estas situações de "não valeu" podem acontecer. E devem ser ainda mais compreendidas como atitudes pertinentes ao jogo se ocorrem em jogos que se dão visando apenas 0 entretenimento dos jogoadores. A diversão é, de alguma forma, a finalidade em si, do próprio ato de jogar. Jogamos, principalmente, para nos divertirmos e passar o tempo. E, em nome desta diversão é que essas cortesias que permitem a negociação de alguns aspectos da regra são permitidas. E isto não torna o jogo menos jogo, esta flexibilização busca apenas atender mais plenamente ao quesito prazer, indispensável ao jogo.

Outra situação que podemos considerar como exeção à regra pode ser observada em um videogame, onde a eventual presença de um erro de programação ou a 
inserção de novos códigos permite ao jogador burlar o sistema e desempenhar ações que inicialmente Ihe seriam vetadas. 0 jogador pode fazer isso até mesmo pelo prazer de descobrir falhas e/ ou burlar o sistema. Outro comportamento ainda, também dentro dessas exceções, estaria nos jogos que permitem voltar no tempo, desfazendo um movimento e dando ao jogador a possibilidade de repensar e refazer a jogada.

Em Braid (Number None, 2008), por exemplo, um dos principais elementos é a manipulação do tempo. Braid é um jogo de plataforma como Donkey Kong (Nintendo, 1981) e The Legend of Zelda (Nintendo, 1986), onde o personagem, Tim, precisa salvar a princesa. O objetivo é viajar por mundos atrás de peças para montar quebra-cabeças mas, para resolver vários deles, o uso da possibilidade de voltar no tempo é fundamental.

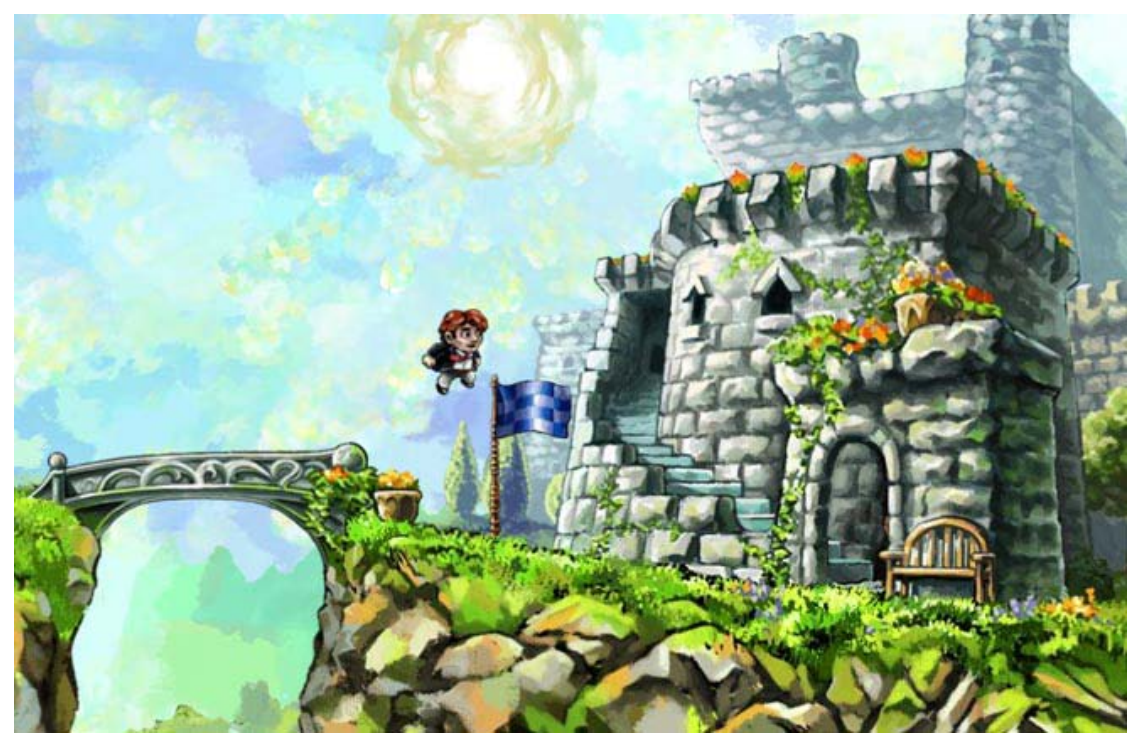

Figura 4. Braid 
E como bem observa Ranhel (2009:15-16), mesmo que as características de J uul não se apliquem de forma ampla a todos os tipos de jogos, estas são adequadas aos videogames (ou jogos computacionais, termo preferido por Ranhel), já que os algoritmos não negociam regras. Eles tendem a ser rígidos e quantificam automaticamente resultados. Possuem formas de valorizar a vitória dos participantes porque geralmente apresentam níveis de dificuldade. Costumam ser imparciais, e o jogador deverá empenhar algum esforço caso queira que o jogo aconteça, ou seja, o vínculo é geralmente um compromisso do jogador consigo mesmo.

E podemos estender este vínculo não apenas restringindo-o ao compromisso que o jogador estabelece consigo mesmo, para aquele que se estabelece em função do resultado, como observa Juul. Pois não é por se tratar de um videogame que o jogador se sentirá menos vinculado ao resultado, inclusive, os algoritmos computacionais podem também nos proporcionar jogos de pura sorte, o que não nos desvinculará da satisfação em ganhar e da frustração ao perder, mesmo que nosso empenho seja apenas o de colocar o jogo em movimento.

\subsubsection{Mais algumas definições de jogo}

O estudo das tabelas propostas por Salen \& Zimmerman (2003) e por J uul (2003), nos levou a nos defrontarmos com outras definições de jogo.

O próprio J uul, em 2000, havia publicado em seu artigo What computer games can and can't do uma definição, buscando responder a questão "o que é um jogo?". J uul 
dizia estar arriscando seu pescoço com uma definição simples de dois pontos: que um jogo é "um passatempo com um conjunto formal e pré-definido de regras que orientam a progressão de uma seção de jogo com definições quantitativas e intrínsecas de sucesso e falha". E que o que acontece num jogo está separado do resto do mundo, sendo considerado "não-real" 44.

Analisando estas definições publicadas em 2000 (mencionada acima) e a de 2003, observamos que nas suas colocações de 2000 , de que o jogo é um processo com vistas a um resultado ("regras que orientam a progressão de uma sessão de jogo com definições quantitativas e intrínsecas de sucesso e fal ha") passa a ser resumido como esforços para influenciar resultado, na definição de 2003 ("4. o jogador exerce esforços para influenciar o resultado") e que ele deixa de dar destaque ao fato do jogo ser considerado não-real, separado do resto do mundo (da definição do artigo, de 2000), para melhor defini-lo como algo a cujo resultado o jogador sentese emocionalmente apegado (em 2003).

Também encontramos uma outra discussão sobre o conceito de jogos elaborada por Zimmerman, desta vez em conjunto com Lantz, publicada em 1999. Lantz \& Zimmerman (1999) não propõem um conceito fechado de jogo, portanto, o que

\footnotetext{
${ }^{44}$ Tradução nossa. Do original em inglês: "What is a game? This is a really good question. I'll risk my neck by coming up with a simple two-point definition. / A game is a pastime with formal and predefined set of rules for the progression of a game session, with built-in and quantitative definitions of success and failure. / . What goes on in a game is considered "unreal"; has another status than the rest of the world" (J uul, 2000).
} 
segue é uma rápida compilação de suas ideias expostas ao longo de todo 0 artigo. E, a fim de abarcar os diversos fenômenos que compõem a experiência de jogar, os autores propõem o entendimento do conceito de jogo em um modelo de três níveis: “1) jogos como conjuntos de regras, 2) jogos como jogos, e 3) jogos como cultura" ${ }^{45}$. Os autores advertem que estas categorias não são absolutas e que se interrelacionam de forma dinâmica e que as fronteiras entre estes níveis são, por vezes, confusas.

Ao tratar do jogo como um conjunto de regras, Lantz \& Zimmerman (ibid) destacam a delimitação das ações que as regras estabelecem:

As regras de um jogo são as leis que determinam o que pode e não pode acontecer no jogo. As regras são um sistema determinista, absolutamente fechado e sem ambiguidades. Para jogar um jogo, os jogadores voluntariamente submetem seus comportamentos para os limites das regras do jogo. Após começar a jogar, os jogadores estão fechados dentro do contexto artificial de um jogo - o seu "círculo mágico" - e devem respeitar as regras, a fim de participar ${ }^{46}$.

\footnotetext{
${ }^{45}$ Tradução nossa. Do original em inglês: "we propose a 3-tiered model of understanding games as systems: 1) games as sets of rules; 2) games as play; and 3 ) games as culture". (Lantz \& Zimmerman, 1999).

${ }^{46}$ Tradução nossa. Do orginal em inglês: "The rules of a game are the laws that determine what can and cannot happen in the game. The rules are a deterministic system, absolutely closed and unambiguous. To play a game, players voluntarily submit their behaviors to the limits of the game rules. Once play begins, players are enclosed within the artificial context of a game - its "magic circle" - and must adhere to the rules in order to participate". (Lantz \& Zimmerman, 1999).
} 
Os autores ressaltam ainda a importância de se observar o que acontece quando as regras são postas em movimento, já que “jogar é algo completamente diferente de regras" $^{47}$, algo que depende das escolhas e ações dos jogadores. E, postas em jogo, as regras podem gerar sistemas complexos, mesmo que, em si mesmas, as regras sejam simples.

Durante o jogo, as relações entre as partes tornam-se um sistema complexo, capaz de produzir intrincados padrões. Mas talvez o mais importante atributo desses padrões complexos seja a sua imprevisibilidade. A incerteza, produzida pela aleatoriedade ou por uma rica paleta de escolha estratégica, é um ingrediente necessário do gameplay bem sucedido ${ }^{48}$.

Ao analisar o jogo enquanto jogo, os autores valorizam a experiência de jogar em toda sua complexidade:

Jogar inclui a completa experiência do jogo que as regras engendram. Esta experiência inclui não apenas a complexidade estratégica do jogo, mas também a experiência estética, psicológica, social e material: tudo o que acontece na mente e no corpo dos jogadores quando eles se submetem ao sistema de regras ${ }^{49}$.

${ }^{47}$ Tradução nossa. Do original em ingles: "play is something altogether different than rules". (Lantz \& Zimmerman, 1999).

48 Tradução nossa. Do original em inglês: “During play, relationships between parts becomes a complex system, capable of producing intricate patterns. But perhaps the most important attribute of these complex patterns is their unpredictability. Uncertainty, produced by randomness or by a rich palette of strategic choice, is a necessary ingredient of successful gameplay." (Lantz \& Zimmerman, 1999).

${ }^{49}$ Tradução nossa. Do original em inglês: "Play includes the complete experience of the game that the rules engender. This experience encompasses not only the strategic complexities of a game, but also aesthetic, psychological, social, and material experience: everything that happens to the minds and the bodies of the players when they submit to the system of rules" (Lantz \& Zimmerman, 1999). 
E como o jogo não existe no vazio, os autores argumentam que para uma completa compreensão do jogo "é necessário olhar além das regras e além do jogo, para examinar a forma como 0 jogo se encaixa nos contextos culturais maiores" ${ }^{50}$, buscando descobrir o que o jogo significa para quem joga e para quem não joga e os significados de suas representações e relações simbólicas que se estabelecem com o resto do mundo. Estas são algumas das considerações que Lantz \& Zimmerman traçam ao tratar o jogo como cultura.

Quando os autores lançam seus olhares para o futuro dos jogos apontam um "indicador da estreita relação entre a família de jogos digitais e não-digitais". Para Lantz \& Zimmerman "não importa o quão sofisticadas sejam suas características representacionais, jogos vivem e morrem, de acordo com suas qualidades enquanto sistemas sociais interativos" ${ }^{51}$.

A presença de regras e o envolvimento do jogador são os elementos que permanecem nas duas definições. Em Salen \& Zimmerman (2003) o foco fica mais voltado para a presença de conflito e a orientação a um resultado, enquanto Lantz

\footnotetext{
50 Tradução nossa. Do original em inglês: "In order to understand the whole game, it is necessary to look beyond rules and beyond play, to consider how the game fits into larger cultural contexts." (Lantz \& Zimmerman, 1999).

51 Tradução nossa. Do original em inglês: "This fact is a good indicator of the close family relationship between digital and non-digital games: no matter how sophisticated their representational features, games live and die according to their qualities as social interactive systems." (Lantz \& Zimmerman, 1999).
} 
\& Zimmerman (1999) destacam a experiência de engajar-se a um jogo (a um sistema de regras).

Walter (2005), no intuito de estabelecer as diferenças entre brincar e jogar, apresenta uma breve definição de jogo: “jogos são áreas confinadas que desafiam a interpretação e a otimização de regras e táticas". Nesta sua definição o autor não destaca a orientação a um objetivo ou resultado, assinala, além das regras, a necessidade de interpretação e otimização destas (tomada de decisão). E não the foge à observação o fato do jogo ser separado da vida cotidiana, ao tratá-lo como "áreas confinadas".

E Fullerton (2008:43) sintetiza sua definição de jogo enfatizando três principais características: o fato de ser

- fechado, um sistema formal

- que engaja os jogadores numa estrutura de conflito

- e resolve suas incertezas em um resultado desigual ${ }^{52}$.

Embora Fullerton não aponte as regras em sua definição, a autora, durante as discussões que elabora para chegar a esta definição coloca as regras como parte

\footnotetext{
52 Tradução nossa. Do original em inglês: "A game is: · A closed, formal system that / · Engages players in structured conflict and / . Resolves its uncertainty in an unequal outcome" (Fullerton, 2008:43).
} 
limitadora do sistema ${ }^{53}$ e como parte responsável pelo engajamento dos jogadores, como podemos observar neste trecho:

Jogos desafiam os jogadores a cumprir seus objetivos enquanto seguem regras e procedimentos que tornam difícil alcançá-10 $0^{54}$ (2008:42).

Greg Costikyan (1994) também não inclui a regra em sua definição. Mas isso não significa que ele não atribua nenhum valor a ela. Para ele, o conjunto de regras de um jogo é a base para os jogadores improvisarem, "criarem suas próprias consequências" e é isso, que para o autor, torna o jogo uma forma de arte como na música de J ohn Cage, "o designer provê o tema e os jogadores a música" ${ }^{55}$.

Uma constante, na maior parte das definições é a presença de regras como elemento definidor do conceito de jogo. Ao consideramos, como fizemos quando discutimos a definição de Huizinga utilizada por Salen \& Zimmerman (ver discussão

\footnotetext{
53 “Quando falamos sobre limites, mencionamos o físico e o conceitual porque são estes com os quais a maioria dos jogos lida em suas regras. 0 que não mencionamos são os limites emocionais entre 0 resto da vida e um jogo. Quando você joga, você deixa de lado as regras da vida para assumir as regras do jogo". Tradução nossa para o original em inglês: "When we talked about boundaries, we mentioned the physical and the conceptual because this is what most games deal with in their rules. What we did not mention is the emotional boundary between the rest of life and a game. When you play a game, you set the rules of life aside and take up the rules of the game instead." (Fullerton, 2008:42)

${ }^{54}$ Tradução nossa. Do original em inglês: "Games challenge players to accomplish their objectives while following rules and procedures that make it diffi cult to do so." (Fullerton, 2008:42).

${ }^{55}$ Tradução nossa. Do original em inglês: "Games provide a set of rules; but the players use them to create their own consequences. It's something like the music of J ohn Cage: he wrote themes about which the musicians were expected to improvise. Games are like that; the designer provides the theme, the players the music." (Costikyan, 1994).
} 
na pág. 31), tanto a definição dada por um autor quanto suas considerações sobre os elementos importantes para a constituição de um jogo, as regras aparecem nas considerações de todos os autores citados. Mesmo Costikyan e Fullerton, que não fazem menção à regra em suas definições, não deixam de fazer menção a ela ao analisar elementos importantes para a constituição do jogo, como foi demonstrado.

O segundo elemento que mais aparece nas definições são os objetivos. Parlett, Abt, Costikyan e Kelley falam dos objetivos como aquilo que deve ser obtido, alcançado, conquistado. Em Suits e Avedon \& Sutton-Smith, os objetivos são deduzidos da menção feita à necessidade de produzir, fazer emergir uma dada situação ou resultado. Em Juul (2003), o objetivo aparece de modo semelhante, quando observamos que ele se refere ao esforço do jogador para influenciar o resultado, ou seja, atingir o seu objetivo. Em seu artigo, J uul divide o objetivo em três aspectos, ao analisar a relação entre objetivo e jogador, sendo os três aspectos: a valorização do resultado, o esforço do jogador e o vínculo que este estabelece com o resultado. E Fullerton (2008:60), embora não cite o objetivo em sua definição, ao analisar os elementos do jogo diz que "além de fornecer desafio, o objetivo de um jogo pode definir o seu tom" ${ }^{56}$

\footnotetext{
${ }^{56}$ Tradução nossa. Do original em inglês: "Objectives give your players something to strive for. (...) In addition to providing challenge, the objective of a game can set its tone." (Fullerton, 2008:60)
} 
Ainda com relação aos objetivos, podemos, tal como Juul e diferentemente de Salen \& Zimmerman, incluir Crawford entre os autores que falam dos objetivos como algo a ser conquistado: “O jogador está ativamente perseguindo algum objetivo".

Os resultados e o fato do jogo ser artificial, separado da vida ordinária são os elementos que aparecem nas definições de oito dos quinze autores, sendo que 0 fato de ser artificial é considerado por Huizinga, Lantz \& Zimmerman (contexto artificial), Crawford (um modo seguro de experimentar a realidade) e Walter (áreas confinadas). Quatro autores referem-se tanto ao fato de ser artifical quanto à importância dos resultados. Caillois (diferente e isolado da vida cotidiana e resultado incerto), Salen \& Zimmerman (conflito artificial e resultado quantificável), Juul, em sua definição de 2000, referindo-se ao fato do jogo ser separado do resto do mundo e possuir definições quantitativas e intrínsecas de resultado e falha (resultado) e Fulerton (fechado e resultado desigual). Os outros quatro em que aparecem os resultados como elemento importante são J uul (2003; exerce esforços para influenciar o resultado e sente-se apegado a ele), Avedon \& Sutton-Smith (resultado desequilibrado), Parlett ("vencer" é o fim) e em Kelley, onde deduzimos esta menção a partir dos objetivos alcançados ("objeto (obj etivo) a ser almejado e os meios permissíveis de consegui-lo"). 
Cinco dos autores estudados (Parlett, Crawford, Avedon \& Sutton-Smith, Salen \& Zimmerman e Fullerton) fazem referência à presença de conflito ou competição em um jogo. E, podemos considerar, assim como para Assis (2007: 9-11), que a presença de competição nos permite estabelecer um contínuo que vai do passatempo ao jogo, já que um passatempo pode incorporar a competição quando estabelecemos uma competição conosco mesmos, buscando nos superar, ou quando, apesar de continuarmos jogando sozinhos, comparamos nossos resultados com os de outros jogadores, estabelecendo alguma forma de ranking.

O termo interação, como elemento definidor de um jogo, vai aparecer pela primeira vez, dentre os autores estudados, na definição de Crawford, em 1984. Da definição dada por Crawford (1984) encontramos algumas semelhanças com as definições dadas por Huizinga (1938) e Caillois (1958), que também entendem o jogo como uma atividade que se desenvolve dentro de um espaço diferente da vida cotidiana que permite a vigência de regras não necessariamente válidas em outro espaço que não aquele do jogo. No entanto, talvez até por ser um dos pioneiros no estudo dos videogames, o autor aponta a interação como um elemento importante na constituição de um jogo ("J ogos provêem este elemento interativo, e é um fator decisivo de seu apelo"). E, embora possamos reconhecer que as definições anteriores pressupõem a presença dessa interação, dentre os autores estudados, apenas Crawford e Lantz \& Zimmerman (1999) fazem referência a ela. Para Lantz \& Zimmerman as qualidades do jogo enquanto sistemas sociais interativos são cruciais para seu sucesso ou fracasso. 
Estas e outras observações a respeito das comparações estabelecidas podem ser melhor observadas na tabela apresentada a seguir, onde reunimos os comparativos de Salen \& Zimmerman (2003) e Juul (2003) e acrescentamos as outras definições citadas: Lantz \& Zimmerman (1999), J ull (2000), Walther (2005) e Fullerton (2008).

Com relação a tabela que elaboramos, cabe chamar a atenção para alguns pontos. Na sua construção buscamos reunir todos os elementos trabalhados por Salen \& Zimmerman (2003) e por J uul (2003), que estão assinalados, conforme suas tabelas e observações, pelas iniciais $S \& Z$, para as notas dos primeiros autores e J para 0 último. As cores assinalam os elementos que acreditamos serem inerentes ao jogo (em azul) ou decorrentes do ato de jogar (em verde). Os itens assinalados em cinza são os que consideramos não relevantes. 


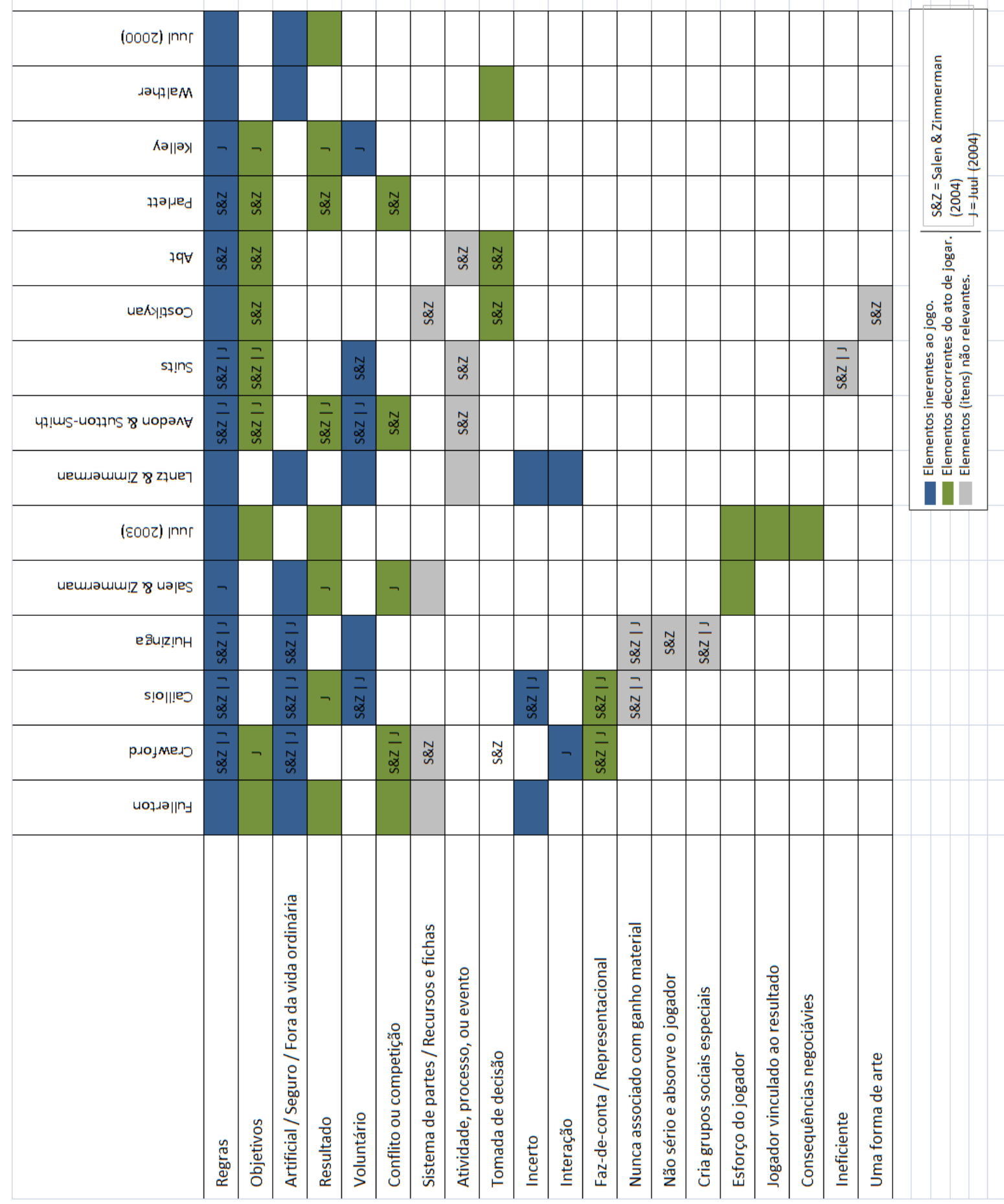

Tabela 4. Tabela comparativa 
Das diferenças que observamos, além das já citadas, inversamente ao entendimento de Salen \& Zimmerman, não acreditamos que a definição de Crawford (1984) envolva uma tomada de decisão. Quando Crawford diz, a respeito da interação, que “a única forma de representar esta teia é permitir que o público explore cada aperto de uma situação, deixar que eles gerem causa e observem os efeitos", entendemos que aí possa estar presente a ideia de tomada de decisão, mas como um conceito inerente a ação do jogador, a quem sempre se solicita uma escolha, uma reação. Mas, não só Crawford não faz menção específica ao ato ou à necessidade de tomar decisões no jogo, como o jogador pode, também, apenas reagir aos estímulos propostos pelo jogo, muito mais numa ação de experimentar 0 ambiente do que na execução de uma ação consciente e determinada.

Embora não tenhamos a pretensão de estabelecer mais uma definição de jogo, estas observações nos permitem elencar os elementos que consideramos essenciais a um jogo, que, assim como Juul (2003) propõe, são aqueles sem os quais uma atividade lúdica não pode ser considerada um jogo. 


\subsection{Elementos essenciais do jogo}

Partindo dos diversos conceitos de jogo vistos até aqui, e posto que o jogo só existe como tal quando posto em movimento pelo jogador, temos como elementos passíveis de análise, o jogo (enquanto artefato, com todas as suas características), o jogador e a intersecção existente entre jogo e jogador, representada pelo ato de jogar.

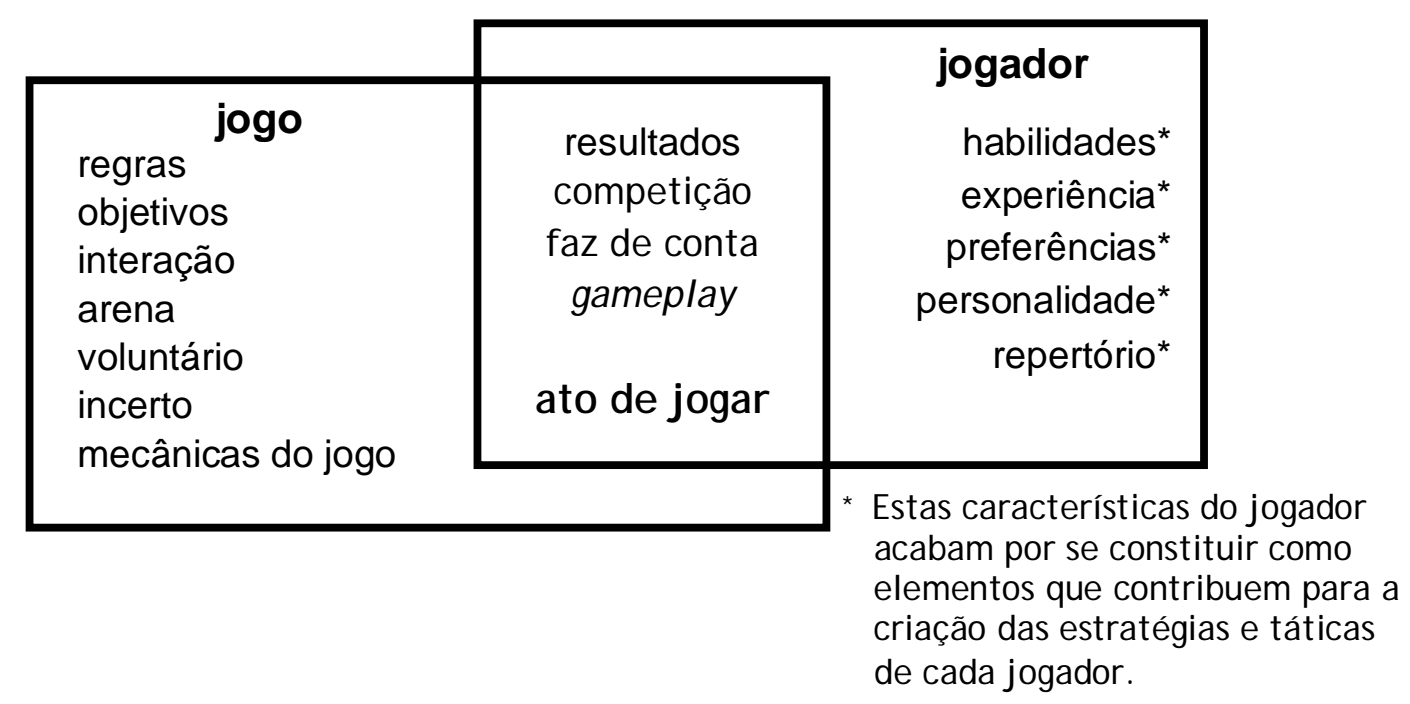

Intersecção entre o jogo e o jogador, 0 ato de jogar.

Os elementos essenciais aos jogos podem ser divididos entre aqueles que são inerentes ao jogo e aqueles que são decorentes do ato de jogar. Como inerentes ao jogo consideramos: as regras e as mecânicas do jogo, os objetivos que orientam 0 jogador, a interação do jogador com as regras e com o espaço artificial, separado da vida cotidiana em que ele se desenrola (arena) e o fato de ser voluntário e incerto. São decorrentes do ato de jogar: o gameplay, os resultados alcançados (em 
função dos objetivos propostos), a competição que se estabelece e o faz de conta que perpassa a interação do jogador com o ambiente do jogo.

Sendo a regra e o gameplay elementos fundamentais em nossa discussão, um capítulo posterior foi reservado a eles. Por ora basta dizermos que as regras são responsáveis por determinar o que o jogador pode ou não pode fazer e o que acontece em virtude de suas escolhas e que o gameplay emerge das interações do jogador com o ambiente do jogo, pela criação de estratégias e táticas que tornam interessante e divertida a experiência de jogar.

\subsubsection{Elementos inerentes aos jogos}

\section{- As mecânicas do jogo}

Para o entendimento do conceito de mecânica de jogo podemos nos valer da definição dada por Sicart (2008) que, para chegar a ela, apresenta e discute, em seu artigo, diversos conceitos anteriores. Para Sicart (2008) "mecânica de jogo são métodos invocados de agentes, concebidos para a interação com o estado do jogo" 57 .

Ao falar em "métodos invocados pelos agentes", Sicart faz uso de uma terminologia oriunda do paradigma de programação orientada a objetos, que lhe permite

\footnotetext{
${ }^{57}$ Tradução nossa. Do original em inglês: "game mechanics are methods invoked by agents, designed for interaction with the game state". (Sicart, 2008)
} 
analisar a mecânica como um elemento que está disponível no jogo tanto para a interação de agentes humanos quanto artificiais. E a segunda parte da definição que coloca as mecânicas de jogo como concebidas para a interação com o estado de jogo, implica o fato de que as interações, tanto do jogador quanto dos agentes artificiais, modificam o estado de jogo.

Assim, podemos entender a mecânica de jogo como o conjunto de elementos disponíveis para a interação e modificação do estado de jogo, a partir da agência tanto do jogador quanto dos agentes artificiais controlados pela Inteligência Artificial (IA).

Sicart ainda apresenta uma distinção útil entre regra e mecânica:

As mecânicas de jogo estão preocupadas com a real interação com o estado de jogo, enquanto as regras preveem o espaço de possibilidades onde a interação é possível, regulando também a transição entre estados. Neste sentido, as regras são modeladas após a agência, enquanto a mecânica é modelada pela agência ${ }^{58}$.

58 Tradução nossa. Do original em inglês: “Game mechanics are concerned with the actual interaction with the game state, while rules provide the possibility space where that interaction is possible, regulating as well the transition between states. In this sense, rules are modeled after agency, while mechanics are modeled for agency." (Sicart, 2008) 


\section{- Os objetivos}

O objetivo pode ser proposto pelo jogo ou estipulado pelo próprio jogador - que nesse caso pode ser mais flexível e adaptável ao seu desempenho durante a partida, aumentando ou diminuindo o grau de dificuldade que se propôs inicialmente.

Mesmo o jogo tendo um objetivo explícito, o jogador pode adotar outra postura e estabelecer para si um objetivo (ou vários) diferente(s) daquele do jogo, tornando sua experiência de jogar ainda mais particular. E este objetivo particular pode ser complementar ou diverso do proposto pelo jogo.

Para alguns jogadores nem sempre o mais importante é se chegar ao objetivo, mas sim o prazer da diversão e do desafio de percorrer o caminho que leva até ele.

Embora alguns jogos aparentemente não tenham um objetivo final definido há sempre um objetivo geral, que guiará os objetivos definidos pelo jogador. Na série The Sims (Eletronic Arts, 2000), o objetivo geral é dar vida aos personagens do jogo, mas cabe ao jogador definir as características físicas e psicológicas que definirão seus comportamentos e suas necessidades, além de decidir o destino de cada um deles. 


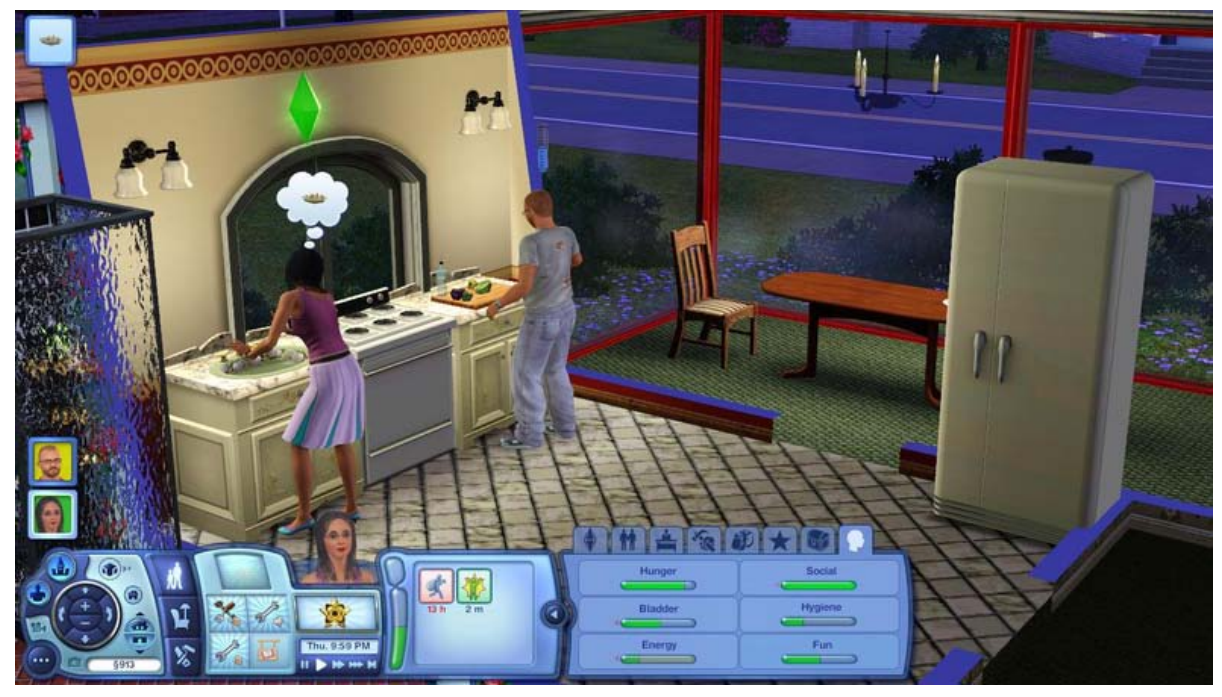

Figura 5. The Sims 3

Outros autores como Fullerton (2008) e Bates (2004) colocam o objetivo como elemento constituinte do jogo. Para eles, os objetivos são importantes para orientar o jogador, e isso fica explícito nas palavras de Bates (2004:18-19):

O jogador deve sempre saber onde ele está no jogo e por que está fazendo o que está fazendo. Em qualquer ponto, ele deveria ter um objetivo a longo prazo, um objetivo de médio prazo e um objetivo imediato. (Isto é verdade mesmo nos softwares-brinquedo, jogos que aparentemente não têm metas, mas que, na realidade, têm uma série de objetivos que o jogador cria para si próprio). ${ }^{59}$.

Estabelecer objetivos de curto e médio prazo é tão ou mais importante que estabelecer os objetivos a longo prazo (ou objetivos gerais) que guiam o jogo como um todo. São os objetivos de médio prazo - em geral relacionados com as mudanças

\footnotetext{
59 Tradução nossa. Do original em inglês: "The player should always know where he is in the game and why he's doing what he's doing. At any given point, he should have a long-term goal, a mediumrange goal, and an immediate goal. (This is true even of software toys, games that ostensibly have no goals, but in reality have a series of goals the player creates for himself. )" (Bates, 2004:18-19)
} 
de fase (ou nível) - e objetivos imediatos - aqueles com os quais o jogador, ao longo de todo o jogo, se defronta - que mantêm a atenção e o envolvimento do jogador.

\section{- A interação}

Não existe jogo sem jogadores. O jogo só ganha corpo, efetivamente, quando posto em ação. É da interação do jogador com o ambiente de jogo que o jogo acontece. São as ações do jogador que modificam o ambiente (ou estado) do jogo e o coloca em funcionamento. Se o jogador não executa nenhum movimento no ambiente do jogo, o jogo não se realiza.

Santaella (2009:62) diz que como um processo que está presente em todos os jogos, a interação está conectada com as exigências de que o jogador realize um ato, tal como mover uma peça em um tabuleiro ou pressionar uma tecla no teclado, um ato que está projetado para ter um sentido específico no mundo do jogo. Essa performance implica a interação do jogador com o estado do jogo, em um processo em que um estado funciona como referente do próximo, e assim por diante.

Para Santaella (ibid) os videogames possuem uma dupla interação.

nos jogos computacionais a interação deve ser compreendida tanto como um processo que está presente em todos os games, quanto no sentido mais estrito da interação ser humano-máquina.

Podemos acrescentar uma terceira forma, se considerarmos a interação máquina-máquina, que acontece quando colocamos competidores em confronto para ver 0 
resultado, como por exemplo, em competições de guerra de robôs (reais ou virtuais).

Para Lévy (1999), a interatividade nos jogos eletrônicos pode ser percebida em seu próprio processo: "o videogame reage às ações do jogador, que por sua vez reage às imagens presentes". Estabelece-se, assim, uma comunicação com a matriz do jogo, com “um modelo capaz de gerar uma quantidade quase infinita de 'partidas' ou de percursos diferentes (mas todos coerentes)".

Esta interação é entendida por Arsenault \& Perron (2009:119-120) em termos de reatividade, uma vez que o jogador apenas reage ao que o jogo Ihe apresenta e, similarmente, o jogo reage às entradas do jogador, considerando então que a divisão temporal entre a figura autoral e o jogador poderia tomar lugar mais em termos de inter(re)atividade do que de interatividade ${ }^{60}$. Concordamos com os autores que a interatividade presente nos jogos possa ser vista como meramente reativa, no entanto, nesta discussão, essa distinção não será levada em conta.

Crawford (1984), o único dos autores analisados durante a conceituação de jogo a citar textualmente a importância da interação como elemento fundamental do

60 Tradução nossa. Do original em inglês: "While we are not arguing here for a change of terminology, this temporal divide between the authorial figure and the gamer would place the video game more along the way of inter(re)activity than interactivity". (Arsenault \& Perron, 2009:119-120) 
jogo, considera que a interatividade é importante ${ }^{61}$, primeiro por injetar um elemento social ou interpessoal aos desafios propostos pelo jogo. Embora os jogos de computador raramente forneçam um adversário humano (com exceção aos multiplayer), eles podem apresentar uma personalidade ilusória contra o qual o jogador tem que trabal har.

Este é uma das potencialidades mais excitantes e menos desenvolvidas do computador como tecnologia de jogo. E, independentemente do êxito ou fracasso do computador em sintetizar um elemento social, o computador pode facilmente tornar o jogo uma experiência altamente interativa para o jogador. Ele pode reagir aos movimentos do jogador com rapidez e rigor ${ }^{62}$.

Devemos, no entanto, observar que a relativização que Crawford faz do "êxito ou fracasso do computador em sintetizar um elemento social" deve-se ao estágio de desenvolvimento dos videogames no período em que o autor publicou seu livro. Hoje, esta "personalidade ilusória" a que ele se refere encontra-se muito mais evoluída, tanto quanto os aspectos gráficos do videogame.

Esta importância da interatividade como elemento para garantir o envolvimento do jogador com o jogo é ainda mais enfatizada pelo autor em Chris Crawford on Game

\footnotetext{
${ }^{61} \mathrm{O}$ autor aponta a interação como um dos quatro fatores comuns a todos os jogos de computadores, sendo os outros três, a representação, o conflito e a segurança.

62 Tradução nossa. Do original em inglês: "This is one of the most exciting and least developed potentials of the computer as a game technology. And regardless of the computer's success or failure in synthesizing a social element, the computer can readily make the game a highly interactive experience for the player. It can react to the player's moves with speed and thoroughness." (Crawford, 1984:12)
} 
Design, onde Crawford (2003:74) aponta a interatividade como o "ponto focal" (schwerpunkt) dos jogos.

Gráficos, animações, sons e músicas são todos necessários para o jogo, e todos eles são importantes, mas eles não o schwerpunkt. Interatividade (...) é o verdadeiro schwerpunkt de jogos ${ }^{63}$.

Também para Bates (2004:18) a interatividade "é o que distingue um jogo de qualquer outra forma de entretenimento". Para o autor a interatividade é entendida como no sentido de feedback, as respostas que o sistema de jogo às ações do jogador ${ }^{64}$.

Para Assis (2007: 30-34) "a interatividade dos videogames é aquela que permite exploração e surpresa e, ao mesmo tempo, é coerente e razoavelmente previsível". 0 autor ainda argumenta que previsibilidade e interatividade não são conceitos opostos, pois, se muitas das ações que realizamos nos videogames têm um correspondente no mundo físico, esperamos que a resposta seja equivalente no mesmo sentido. O acender ou apagar de uma luz através do pressionar um interruptor é o exemplo dado por Assis para esta situação.

\footnotetext{
${ }^{63}$ Tradução nossa. Do original em inglês: "Graphics, animation, sound, and music are all necessary to gaming, and they're all important, but they're not the schwerpunkt. Interactivity (sometimes called "gameplay") is the real schwerpunkt of games." (Crawford, 2004:74)

${ }^{64}$ Tradução nossa. Do original em inglês: "It's the interactivity that makes our games unique. Without it, the player would just be watching a movie on the screen. Every input the player makes in the game should give him a discernible response. No input should go unanswered. This "answer" can take many forms. It can be visual feedback, aural feedback, or even tactile feedback (if the controller is so equipped). It can be positive feedback or negative feedback, but there must be some feedback." (Bates, 2004:18)
} 
A interação do jogador com o ambiente do jogo é um dos componentes importantes para o envolvimento do jogador, ao Ihe proporcionar a sensação de estar no comando do jogo, mesmo que suas ações estejam dentro das limitações impostas pelo programa.

\section{- A arena}

Ao participar de um jogo, o jogador se coloca numa postura diferente da cotidiana, penetra num círculo mágico que o circunscreve a um tempo e espaços distintos do tempo e espaço ordinários do dia a dia, um tempo e espaço regido pelas regras específicas do jogo, com consciência destes serem distintos do cotidiano.

Este espaço regido pelas regras específicas do jogo é o que chamamos de arena, o espaço delimitado artificialmente, separado da vida cotidiana, em que o jogo acontece. Podem ser as quatro linhas de um campo de futebol, o tabuleiro e seu entorno no caso de um jogo de tabuleiro, uma mesa, para um jogo de dominós ou cartas, por exemplo. Nos videogames, podem ir além do espaço da tela visualizado pelo jogador, abrangendo todo o sistema de mundo no qual o jogo se desenrola.

Este espaço separado da vida cotidiana é o que Huizinga chama de "círculo mágico", fazendo uma referência ao espaço ritual que o jogo cria. Uma de suas características importantes é o fato de criar um espaço onde os jogadores sintam- - 
se seguros de que o jogo é temporário, que irá terminar, ou que poderá deixar o jogo caso não queira mais jogar.

Fullerton (2008:78) e Rollings \& Adams (2003:36-37; 55-87) também estabelecem esta relação entre o espaço do jogo e o círculo mágico de Huizinga. Para Rollings \& Adams (2003:36-37; 55-87), esta definição dos limites do "mundo do jogo", do ambiente onde ele acontece é responsável por colocar o jogador "dentro do jogo".

Este "estar dentro do jogo", mergulhado em seu universo, contribui para o envolvimento e a imersão do jogador dentro do ambiente do jogo.

\section{- A atividade voluntária}

A respeito do jogo ser considerado uma atividade voluntária Caillois (1958:26) esclarece

é indiscutível que o jogo deve ser definido como uma atividade livre e voluntária, fonte de alegria e divertimento. Um jogo em que fossemos forçados a participar deixaria imediatamente de ser jogo. Tornar-se-ia uma coerção, uma obrigação de que gostaríamos de nos libertar rapidamente. Obrigatório ou simplesmente recomendado, o jogo perderia uma de suas características fundamentais, 0 fato de o jogador a ele se entregar espontaneamente, de livre vontade e por exclusivo prazer, tendo a cada instante a possibilidade de optar pelo retiro, pelo silêncio, pelo recolhimento, pela solidão ociosa ou por uma atividade mais fecunda. 
E, mesmo que consideremos a observação de J uul (2005:31-33) de que um jogador pode ser levado a jogar por pressão social e, que isto não faça do jogo menos jogo, ainda assim, como já dissemos, acreditamos que é, em parte, no fato de ser uma atividade voluntária, que reside o prazer de jogar. 0 jogo que se estabelece por dever ou obrigação pode até ser prazeroso, quando a sensação de dever ou obrigação desaparece e a atividade passa ser uma opção livre do jogador.

Esta livre opção por participar do jogo está intima e diretamente ligada ao que consideramos ser a função primordial dos jogos: ser um passatempo divertido e prazeroso para quem dele participa.

\section{- O fator incerteza}

O fato de o jogo ser incerto é uma das características que faz dele uma atividade interessante. Como dizemos trivialmente, "não tem graça" um jogo que já sabemos como terminará.

É o caso aqui de um jogo da velha, quando praticado por jogadores habilidosos, que conhecem muito bem o funcionamento do jogo. 0 jogo, invariavelmente, terminará empatado. E este é o motivo pelo qual Juul julga ser o jogo da velha um jogo para crianças. 
Na qualidade de uma criança, o jogo da velha continua interessante porque você ainda acha as escolhas desafiadoras mentalmente. Depois de descobrir o princípio, você vai conseguir empatar cada vez que jogar ${ }^{65}$.

Ainda podemos afirmar que existe alguma incerteza em jogos que julgamos saber como terminarão. Nestes casos, mesmo que o provável resultado se confirme, ainda haverá a incerteza do percurso até o resultado. E o resultado poderá surpreender, não se confirmando.

Incerteza durante o percurso não significa que as regras mudem ao acaso no decorrer do jogo, mas que não podemos prever a sequência de desafios que nos levará ao seu final. Embora muitas vezes conheçamos o tipo de desafio que vamos enfrentar, a aleatoriedade dos elementos e/ ou emergência de situações que os jogos nos apresentam podem nos surpreender.

Em jogos de raciocínio como Campo Minado (criado por Robert Donner, em 1989) ou Tetris (Alexey Pajitnov, 1984), sabemos o que temos que fazer, mas não podemos prever a sequência dos elementos além da peça seguinte, no caso de Tetris, ou a posição das bombas, em Campo Minado, correndo o risco de já no primeiro clique detonarmos uma bomba, uma vez que elas nunca estão nos mesmos lugares da partida anterior.

\footnotetext{
65 Tradução nossa. Do original em inglês: "As a child, tic-tac-toe remains interesting because you still find the choices mentally challenging. Once you figure out the principle, you will achieve a draw every time you play". (J uul, 2003)
} 


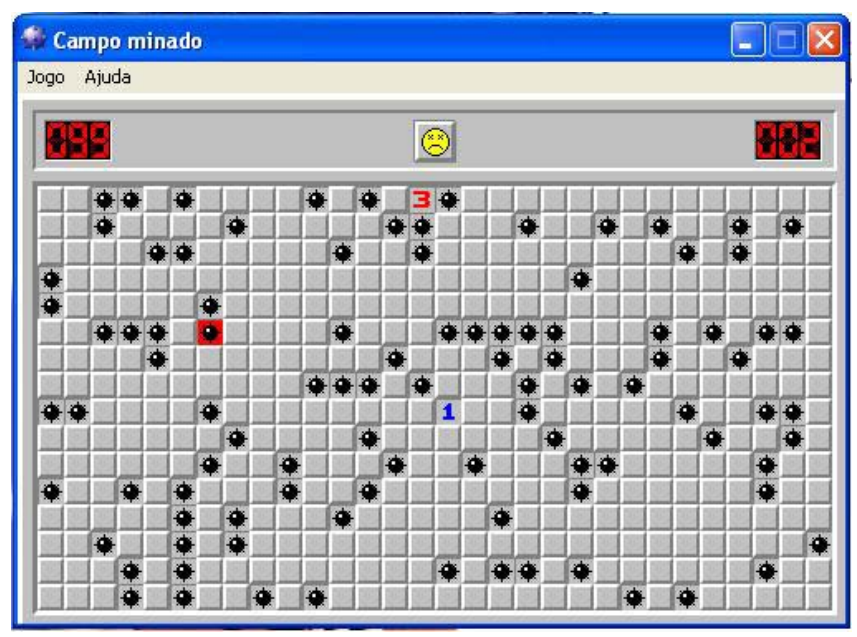

Figura 6. Campo Minado

Parte da atração do jogo está nesta indefinição e incerteza do final (e do percurso), que gera elementos de tensão que envolvem o jogador.

\subsubsection{Elementos decorrentes do ato de jogar}

\section{- Os resultados alcançados}

Os resultados são considerados inerentes ao ato de jogar tanto por serem definidos em função dos objetivos propostos quanto porque só podem ser alcançados se 0 jogo for posto em movimento, portanto, dependem do ato de jogar.

Os resultados podem ser considerados parciais, quando o jogador suspende temporariamente 0 ato de jogar, deixando o jogo para ser continuado mais tarde, ou finais, quando o jogador termina o jogo alcançando ou não o resultado esperado (vencendo ou perdendo o jogo) ou quando simplesmente desiste de jogar. 
Para as situações onde o jogador termina o jogo, vencendo ou perdendo, podemos nos utilizar do que Frasca chama de regras de resultado. Para Frasca (1997:31-34) as regras de resultado servem para definir o resultado final dos jogos.

\section{- A competição}

A competição se estabelece ou quando o jogador cria um desafio para si mesmo, propondo-se vencer o jogo ou buscando se superar ou comparando seus resultados com os de outros jogadores, estabelecendo um ranking.

A competição é, pois, decorrente dos desafios presentes no jogo e, tal como os resultados, apenas se institui a partir do momento em que o jogo é jogado.

A presença de conflito ou competição em um jogo é entendida, por diversos autores, como um elemento importante para a construção do envolvimento do jogador com o jogo.

Para Crawford (1984:13-14) obstáculos colocados no caminho do jogador, rumo à conquista do seu objetivo, exigem um agente inteligente. "Se o agente inteligente bloqueia ativamente o jogador que tenta alcançar seus objetivos, o conflito entre 0 
jogador e o agente é inevitável" ${ }^{66}$. O conflito, no entendimento do autor, é a presença de desafios com os quais o jogador se bate, seja contra outro jogador, ou contra a Inteligência Artificial programada do jogo. O que não existe é jogo sem conflito.

0 conflito só pode ser evitado através da supressão das respostas ativas às ações do jogador. Sem resposta ativa, não pode haver interação. Assim, expurgar o conflito de um jogo inevitavelmente destrói o jogo.

Embora seja impossível eliminar conflitos de um jogo sem destruir o jogo, é possível incluir elementos cooperativos para transferir o conflito. Os membros de uma equipe podem colaborar uns com os outros, no conflito com outro agente. Esse outro agente pode ser outra equipe, um indivíduo humano, ou um computador simulando um jogador. Em todos os casos, o adversário deve ser perceptível como dotado de uma persona. Sem pelo menos a ilusão de uma reação proposital às ações do jogador, o jogo colapsa ${ }^{67}$.

66 Tradução nossa. Do original em inglês: "If that intelligent agent actively blocks the player's attempts to reach his goals, conflict between the player and the agent is inevitable." (Crawford, 1984:13).

${ }^{67}$ Tradução nossa. Do original em inglês: "Conflict can only be avoided by eliminating the active response to the player's actions. Without active response, there can be no interaction. Thus, expunging conflict from a game inevitably destroys the game. / While it is impossible to eliminate conflict from a game without destroying the game, it is possible to include cooperative elements by shifting the conflict. Members of a team can cooperate with each other in the team's conflict with another agent. This other agent could be another team, an individual human, or a computer simulated player. In all cases, the opponent must be perceivable as endowed with a persona. Without at least the illusion of purposeful reaction to the player's actions, the game collapses." (Crawford, 1984:13). 
E se, no mais das vezes, o conflito é apresentado em termos de violência é porque esta "é a mais óbvia e natural expressão de conflito" ${ }^{68}$, embora os jogos não precisem, necessariamente, ser assim.

Para Fullerton (2008: 77) os obstáculos são a origem mais comum dos conflitos, e podem tanto ter uma forma física (como a presença de água em um campo de golfe) quanto envolver habilidades mentais (um puzzle num jogo de aventura). Mas os conflitos também podem ser colocados pela presença de oponentes ou de dilemas na tomada de decisão.

Também para Salen \& Zimmerman (2003:387) o conflito vem da luta dos jogadores para atingir os seus objetivos, que num jogo, nunca são fáceis de serem alcançados. No jogo, o conflito "provê oportunidades tanto para os eventos narrativos quanto para o contexto narrativo que delimita os obstáculos que o jogador deve superar" ${ }^{69}$. Os autores lembram ainda que conflito presuma uma oposição de forças, que no caso dos jogos, são elementos que tentam deliberadamente provocar a falha do jogador.

68 Crawford, 1984:14. Tradução nossa. Do original em inglês: “Violence is not essential or fundamental to games. It is common in games because it is the most obvious and natural expression for conflict".

${ }^{69}$ Tradução nossa. Do original em inglês: "Game conflict provides both opportunity for narrative events and a narrative context that frames the obstacles a player must overcome." (Salen \& Zimmerman, 2003:387). 
Este papel é muitas vezes exercido por um personagem vilão, um jogador ou uma equipe adversária, ou podem ser incorporadas no jogo pelo sistema como um todo. A partir de uma perspectiva narrativa, este elemento motiva e contextualiza as ações do jogador ${ }^{70}$.

\section{- 0 faz de conta}

O faz de conta deve aqui ser entendido no mesmo sentido dado por Caillois ao se referir ao jogo como fictício, proporcionando uma crença especial de uma segunda realidade ou de uma livre irrealidade, contrária à vida real.

Este senso de faz de conta é responsável por tornar nossas ações significativas dentro do ambiente de jogo. Quando nos entregamos ao universo criado pelas regras e aceitamos suas condições este faz de conta se instaura. Pode ser a simples aceitação de ser representado por um peão, digamos amarelo, em um jogo de tabuleiro, cujos movimentos e ações estão restritos pelas regras ou pela aceitação das regras de um videogame, em que participamos de uma história que se desenrola ao longo do jogo, na pele de um personagem que nos representa naquele mundo.

\footnotetext{
70 Tradução nossa. Do original em inglês: “Because conflict presumes a struggle between opposing forces, in a game there should always be some element that works against player success, an element that acts to try and ensure the failure of the player. This role is often taken by a villain character, a competing player or team, or may be embodied in the game system as a whole. From a narrative perspective, this element motivates and contextualizes player action." (Salen \& Zimmerman, 2004:387).
} 
Identificamos alguma semelhança entre nossa aceitação das regras e de nosso desempenho por meio de algo que nos represente no jogo com o conceito de protagonista de Bobany (2008:43)

Podemos definir que o protagonista, no âmbito dos games, é uma entidade física envolvida em alguma atividade. Esta definição torna fácil a identificação do protagonista em qualquer jogo e, rapidamente, podemos determinar que todos os jogos possuem um protagonista, e é o jogador que 0 controla.

Bobany considera que em Tetris, por exemplo, o protagonista sejam os blocos geométricos controlados pelo jogador. Bobany argumenta que os jogos atuais apresentam protagonistas "tão complexos que nos apegamos rapidamente". Observamos tal qual o autor que isto pode ser observado nas situações em que o jogador, ao relatar suas experiências, descreve as ações do personagem "usando o 'Eu' em vez do 'Ele'".

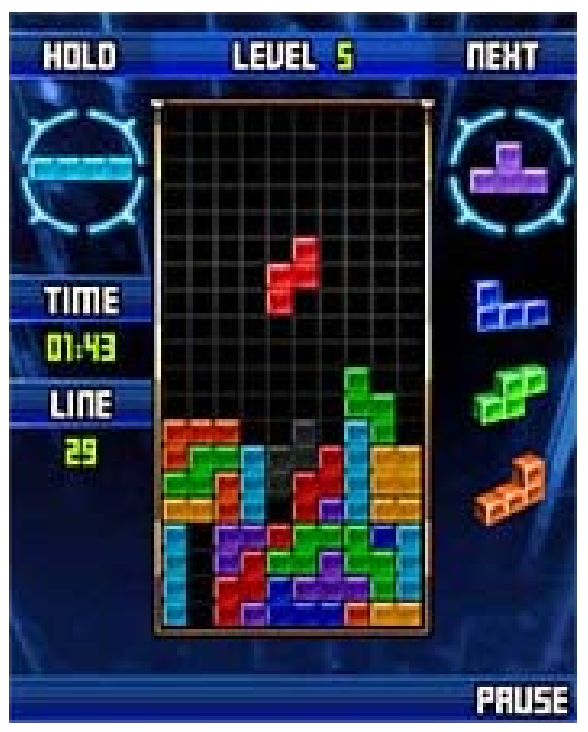

Figura 6. Tetris

Não concordamos, no entanto, que qualquer peça controlada pelo jogador possa ser considerada um protagonista. Acreditamos que esse título deva ser reservado para os personagens com os quais o jogador se identifica, colocando-se no seu lugar. 
Acreditamos por outro lado, que o protagonista seja muito importante para que 0 faz de conta se instaure, já que é por meio de um personagem (ou de uma peça) que o jogador participa do jogo. E que a sensação de outra realidade que o faz de conta proporciona é mais forte e perceptível nos jogos em que o jogador representa um personagem.

Para Caillois (1958:29) os jogos não podem ser ao mesmo tempo regulamentados e fictícios. "São, antes, ou regulamentados ou fictícios". Mas observamos que isto não se aplica aos videogames, uma modalidade de jogo que ainda nem existia quando Caillois escreveu seu livro. Nos videogames tanto temos regras que regulam o mundo do jogo e as ações do jogador como nos entretemos participando, na pele de um personagem, de um mundo ficcional onde temos um papel a representar e um destino a cumprir.

Embora o faz de conta seja mais perceptível nos jogos com narrativas, o simples fato de participar de uma realidade outra, que não a nossa cotidiana, tem a sua pequena parcela de faz de conta e nos permite mergulhar em outros universos, nos liberando temporariamente das tensões e dos afazeres diários.

O quadro a seguir sumaria os elementos essenciais do jogo. 


\section{ELEMENTOS ESSENCIAIS DO J OGO}

\section{INERENTES AO J OGO}

\begin{tabular}{|l|l|}
\hline Regras & $\begin{array}{l}\text { São responsáveis por determinar o que o jogador pode ou não } \\
\text { pode fazer e o que acontece em virtude de suas escolhas, } \\
\text { orientando sua ação no sentido de produzir resultados } \\
\text { significativos no âmbito do jogo. Devem ser claras e não } \\
\text { ambíguas de forma que sua compreensão contribua para que o } \\
\text { jogador possa desenvolver um estilo pessoal de jogo em função } \\
\text { de seu repertório e suas habilidades, contribuindo para que o } \\
\text { jogo proporcione ao jogador uma experiência prazerosa e } \\
\text { significativa. }\end{array}$ \\
\hline Mecânicas & $\begin{array}{l}\text { Conjunto de elementos disponíveis para a interação e } \\
\text { modificação do estado de jogo, a partir da agência tanto do } \\
\text { jogador quanto dos agentes artificiais controlados pela } \\
\text { Inteligência Artificial (IA). }\end{array}$ \\
\hline Objetivos & $\begin{array}{l}\text { o objetivo pode ser proposto pelo jogo ou estipulado pelo } \\
\text { próprio jogador. Mesmo que o jogo tenha um objetivo explícito, } \\
\text { o jogador pode adotar outra postura e estabelecer para si um } \\
\text { objetivo (ou vários) diferente(s) daquele do jogo, tornando sua } \\
\text { experiência de jogar ainda mais particular. E este objetivo } \\
\text { particular pode ser complementar ou diverso do proposto pelo } \\
\text { jogo. }\end{array}$ \\
\hline Interação & $\begin{array}{l}\text { São as ações do jogador que modificam o ambiente do jogo e o } \\
\text { coloca em funcionamento. É um dos componentes importantes } \\
\text { para o envolvimento do jogador, ao lhe proporcionar a sensação } \\
\text { de estar no comando do jogo, mesmo que suas ações estejam } \\
\text { dentro das limitações impostas pelo programa. }\end{array}$ \\
\hline
\end{tabular}




\begin{tabular}{|c|c|}
\hline Arena & $\begin{array}{l}\text { Refere-se ao espaço regido pelas regras específicas do jogo, } \\
\text { delimitado artificialmente, separado da vida cotidiana, em que } \\
\text { o jogo acontece. Nos videogames pode ir além do espaço da } \\
\text { tela visualizado pelo jogador, abrangendo todo o sistema de } \\
\text { mundo no qual o jogo se desenrola. Por definir os limites em } \\
\text { que o jogo se desenrola é responsável por colocar o jogador } \\
\text { "dentro do jogo", o que contribui para seu envolvimento e } \\
\text { imersão no ambiente do jogo. }\end{array}$ \\
\hline Voluntário & $\begin{array}{l}\text { A livre opção por participar do jogo está intima e diretamente } \\
\text { ligada ao que consideramos ser a função primordial dos jogos: } \\
\text { ser um passatempo divertido e prazeroso para quem dele } \\
\text { participa. O prazer de jogar reside, em parte, no fato deste ser } \\
\text { uma atividade voluntária. }\end{array}$ \\
\hline $\begin{array}{l}\text { Fator de } \\
\text { incerteza }\end{array}$ & $\begin{array}{l}\text { O fato de o jogo ser incerto é uma das características que faz } \\
\text { dele uma atividade interessante. Parte de sua atração está na } \\
\text { indefinição e incerteza do final, que gera elementos de tensão } \\
\text { que envolvem o jogador. }\end{array}$ \\
\hline \multicolumn{2}{|c|}{ DECORRENTES DO ATO DE J OGAR } \\
\hline Gameplay & $\begin{array}{l}\text { Emerge das interações do jogador com uma determinada } \\
\text { construção lúdica, a partir de seu envolvimento com as regras e } \\
\text { da manipulação de suas mecânicas, por meio da criação de } \\
\text { estratégias e táticas que constroem a experiência de jogar. }\end{array}$ \\
\hline Resultados & $\begin{array}{l}\text { Os resultados são considerados inerentes ao ato de jogar tanto } \\
\text { por serem definidos em função dos objetivos propostos quanto } \\
\text { porque só podem ser alcançados se o jogo for posto em } \\
\text { movimento. Os resultados podem ser considerados parciais, } \\
\text { quando o jogador suspende temporariamente o ato de jogar, } \\
\text { deixando o jogo para ser continuado mais tarde, ou finais, } \\
\text { quando o jogador termina o jogo alcançando ou não o resultado } \\
\text { esperado ou quando simplesmente desiste de jogar. }\end{array}$ \\
\hline
\end{tabular}




\begin{tabular}{|l|l|}
\hline Competição & $\begin{array}{l}\text { A competição se estabelece ou quando o jogador cria um } \\
\text { desafio para si mesmo, propondo-se vencer o jogo, ou buscando } \\
\text { se superar ou comparando seus resultados com os de outros } \\
\text { jogadores, estabelecendo um ranking. É decorrente dos desafios } \\
\text { presentes no jogo e, tal como os resultados, apenas se institui a } \\
\text { partir do momento em que o jogo é jogado. }\end{array}$ \\
\hline Faz de conta & $\begin{array}{l}\text { O faz de conta deve aqui ser entendido no mesmo sentido dado } \\
\text { por Caillois ao se referir ao jogo como fictício, proporcionando } \\
\text { uma crença especial de uma segunda realidade ou de uma livre } \\
\text { irrealidade, contrária à vida real. Este senso de faz de conta é } \\
\text { responsável por tornar nossas ações significativas dentro do } \\
\text { ambiente de jogo e instaura-se quando nos entregamos ao } \\
\text { universo criado pelas regras e aceitamos suas condições. }\end{array}$ \\
\hline
\end{tabular}

Quadro 1. Resumo dos elementos esssenciais do jogo. 



\section{Capítulo II: Regras e Gameplay}

“Um jogo bem concebido não pode ser vencido sem estratégia". (Rollings \& Morris, 2003:62)

\subsection{Regras}

Vimos que as regras são um elemento importante na definição de um jogo.

Frasca (1997:108) diz que o estudo destas pode ajudar na compreensão dos jogos e fornecer subsídios para estudos realizados por outras disciplinas como a psicologia, a sociologia ou a antropologia, já que as regras "estão profundamente relacionadas aos problemas colocados pelo jogo ao jogador" ${ }^{71}$.

Observamos que para diversos autores a regra é fundamental na constituição mesma dos jogos. Se para J uul (2000) as regras que devem ser bem-definidas "para não permitir que sejam questionadas a cada vez que se joga (em um jogo de cartas ou tabuleiro) ou suficientemente claras que possam ser implementadas em um

${ }^{71}$ Tradução nossa. Do original em espanhol: “De la misma forma que la temática y los elementos presentes en los juegos pueden ser de gran utilidad para disciplinas como la psicología, la sociología - la antropología, creemos que las reglas también pueden aportar información valiosa. Las reglas están profundamente relacionadas con los problemas que plantea al jugador un game." (Frasca, 1997:108) 
programa de computador"72, Salen \& Zimmerman (2003:117-125) vão além apontando-as como inerente aos jogos, como constituintes de sua estrutura formal a ponto de definir as características dos jogos.

J ogar um jogo é seguir suas regras.

Regras são uma das principais qualidades de jogos: cada jogo tem um conjunto de regras. Inversamente, cada conjunto de regras define um jogo. As regras são a estrutura formal de um jogo, o conjunto fixo de orientações resumidas sobre como funciona um sistema de jogo ${ }^{73}$.

Salen \& Zimmerman (2003:117-125) apontam ainda algumas características das regras, que são compartilhadas por todos os jogos. Para os autores, as regras

- limitam a ação dos jogadores,

- são explícitas e não ambíguas,

- são partilhadas por todos os jogadores,

- são fixas,

- acordadas, e

- passíveis de serem repetidas.

\footnotetext{
72 Tradução nossa. Do original em inglês: "Games have rules that must be sufficiently well-defined that you do not argue about them every time you play (in a board or card game), or sufficiently clear that they can be implemented in a computer program." (J uul, 2000)

73 Tradução nossa. Do original em inglês: "To play a game is to follow its rules. / Rules are one of the essential qualities of games: every game has a set of rules. Conversely, every set of rules defines a game. Rules are the formal structure of a game, the fixed set of abstract guidelines describing how a game system functions." (Salen \& Zimmerman, 2003:117)
} 
Em seu livro Half-Real, de 2005, Juul coloca que entender as regras como limitadoras das ações do jogador é ver apenas metade do cenário que as regras descrevem, uma vez que as regras também são importantes para estabelecer as ações potenciais, ações que sejam significantes dentro do jogo.

Ainda trabalhando com o conceito de regras, o autor define como estas funcionam. Para ele:

1. Regras são concebidas para estar acima de discussão, no sentido de que uma regra específica tem que ser suficientemente clara para que os jogadores possam concordar sobre como utilizá-la. Regras descrevem o que os jogadores podem e não podem fazer, e o que pode acontecer em resposta a suas ações. Regras devem ser implementáveis sem nenhuma habilidade.

2. As regras de um jogo constroem uma máquina de estados, uma máquina que responde às ações do jogador (independentemente de se o jogo é desempenhado com o uso de um computador ou não).

3. A máquina de estados de um jogo pode ser vista como um panorama de possibilidades ou uma árvore do jogo ramificando possibilidades de momento a momento durante uma partida do jogo. J ogar é interagir com a máquina de estados e explorar a árvore do jogo.

4. Desde que um jogo tenha múltiplos resultados, o jogador deve despender esforços tentando alcançar o resultado mais positivo possível. Usualmente, é mais difícil alcançar um resultado positivo do que um negativo, portanto, o jogador enfrenta um desafio.

5. 0 modo como o jogo é realmente jogado quando o jogador tenta superar os desafios é o seu gameplay. 0 gameplay é uma interação entre as regras e a tentativa do jogador em jogar tão bem quanto possível.

6. Jogos são experiências de aprendizagem, onde o jogador aprimora suas habilidades em jogar. Em um dado ponto, o jogador terá um repertório específico de habilidades e métodos de superação dos desafios do jogo. Parte 
da atração de um bom jogo é que ele continuamente desafia e faz novas exigências ao repertório do jogador.

7. Qualquer jogo específico pode ser mais ou menos desfiador, enfatizar tipos específicos de desafios, ou apenas servir como pretexto para um evento social. Este é o modo pelo qual as regras podem dar aos jogadores experiências agradáveis, e diferentes tipos de jogos podem dar diferentes experiências $^{74}$.

Além de Salen \& Zimmerman (2003) e Juul $(2000,2005)$ diversos outros autores discutiram o conceito e o papel das regras em um jogo. Para a maioria deles, as regras orientam e limitam a ação do jogador. Limitam, no sentido de que define 0 que o jogador pode e não pode fazer no âmbito do jogo e o orientam ao estabelecer

\footnotetext{
${ }^{74}$ Tradução nossa. Do original em inglês: “1. Rules are designed to be above discussion in the sense that a specific rule should be sufficiently clear that players can agree about how to use it. Rules describe what players can and cannot do, and what should happen in response to player actions. Rules should be implementable without any ingenuity./ 2. The rules of the game construct a state machine, a "machine" that responds to player action (regardless of whether the game is played using computer power or not). / 3. The state machine of the game can be visualized as a landscape of possibilities or a branching game tree of possibilities from moment to moment during the playing of the game. To play a game is interact whith the state machine and to explore the game tree./ 4 . Since a game has multiple outcomes, the player must expend effort trying to reach as positive an outcome as possible. It is usually harder to reach a positive outcome than a negative one - harder to win than to lose. If the player works toward the positive outcome, the player therefore faces a challenge./ 5. The way the game is actually played when the player tries to overcome its challenge is its gameplay. The gameplay is an interaction between the rules and the player's attempt at playing the game as well as possible./ 6. Games are learning experiences, where the player improves his or her skills at playing the game. At any given point, the player will have a specific repertoire of skills and methods fore overcoming the challenges of the game. Part of the attraction of a good game is that it continually challenges and makes new demands on the player's repertoire. / 7. Any specific game can be more or less challenging, emphasize specific types of challenges, or even serve as a pretext for a social event. This is a way in which rules can give players enjoyable experiences, and different games can give different experiences". (J uul, 2005:55-56)
} 
significados para as suas ações. Estas duas características se observam nas definições de Juul (2005), Gingold (2003), Prensky (2001), e Sato (2009). Salen \& Zimmerman (2003) falam apenas nas regras limitando as ações do jogador, enquanto Santaela (2009) e Fullerton (2008) as observam como importantes na orientação do jogador.

Chaim Gingold (2003:74) entende as regras como "uma teia de limitações" que organiza tanto as peças móveis do jogo quanto as experiências do jogador, permitindo-Ihe uma ação rápida. São elas também as responsáveis pela inteligibilidade e plasticidade do sistema, estabelecendo valores aos estados particulares do jogo. Além dele, já vimos em Juul (2005), quando ele descreve como as regras funcionam, a mesma referência a determinação dos estados particulares de jogo, por parte das regras.

Para Lantz \& Zimmerman (1999), as regras são "Ieis que determinam o que pode e não pode acontecer no jogo", constituindo assim um sistema determinista, "absolutamente fechado e sem ambiguidades" 75 . De sua definição, a única correspondência com as características citadas pelos outros autores é a referência à falta de ambiguidades, que também é colocada por Salen \& Zimmerman (2003).

\footnotetext{
${ }^{75}$ Tradução nossa. Do original em inglês: "The rules of a game are the laws that determine what can and cannot happen in the game. The rules are a deterministic system, absolutely closed and unambiguous". (Lantz \& Zimmerman, 1999)
} 
A definição de Prensky (2001:119) apresenta um novo elemento, entendendo as regras como responsáveis por colocar o jogador dentro do mundo do jogo. Para o autor são elas também o elemento responável por diferenciar os jogos de outros tipos de brincadeira ("provavelmente a mais básica definição de um jogo é que ele é uma brincadeira organizada, isto é, baseado em regras" ${ }^{76}$ ). Para ele, as regras são importantes para os jogos porque impõem limites, forçam os jogadores a tomar os mesmos caminhos específicos para atingir metas e os coloca dentro do mundo do jogo, definindo o que está dentro e fora desses limites.

Para Santaella (2009:57), "sem regras, quaisquer jogos de quaisquer tipos, não apenas os computacionais seriam impossíveis. Todo jogo começa com um conjunto de regras que guiará os jogadores ao longo dos seus diferentes estágios, em direção a um alvo". Para a autora, as regras sustentam a estrutura do jogo e seus possíveis significados, permitindo assim que o jogo se torne auto-exploratório.

Fullerton (2008:71) não nos traz nenhum elemento novo na caracterização das regras, mas ela ressalta a importância destas serem claras para os jogadores, de forma que, principalmente nos jogos digitais, possam ser entendidas intuitivamente, "de modo que o jogo pareça justo e responsivo a determinadas situações" ${ }^{77}$. Para a autora é importante lembrar que quanto mais complexas forem

\footnotetext{
${ }^{76}$ Tradução nossa. Do original em inglês: "Probably the most basic definition of a game is that it is organized play, that is to say rule-based". (Prensky, 2001:119)

77 Tradução nossa. Do original em inglês: "Rules need to be clear to players, or, in the case of digital games that adjudicate for players, they need to be intuitively grasped so that the game seems fair
} 
as regras, mais será exigido do jogador no sentido de compreendê-las e quanto menos eles compreenderem as regras, menos serão capazes de fazer escolhas significativas e menos se sentirão no controle do jogo.

Para Sato (2009:44) as duas características, que apresentamos como as mais importantes para diversos autores, são exatamente o que definem as regras, uma vez que estas "indicam limitações, caminhos, opções, elementos de interação e objetivos ao jogador". São elas que orientam o jogador ao longo do jogo e indicam condutas; em conjunto com os elementos do jogo, formam o sistema do jogo.

Já Ang (2006:307) é o único a ver as regras como importantes para "definir o espaço narrativo" ${ }^{78}$ de modo que este seja consistente e coerente. Para o autor, uma vez que os acontecimentos narrativos influenciam as regras do jogo, afetam a forma como os jogos são jogados.

Dentro do espaço do jogo, o jogador mergulha num universo de possibilidades, limitado pelas regras, mas aberto à exploração e à imaginação. Exploração esta que se dá na medida em que o jogador interage com o jogo, seja descobrindo as regras que o regem, resolvendo os enigmas que lhe são propostos, ou mesmo percorrendo os diversos caminhos possíveis que Ihe são apresentados.

and responsive to given situations". (Fullerton, 2008:71)

${ }^{78}$ Tradução nossa. Do original em inglês: "Game rules are important to define the narrative space so that it is consistent and coherent while narrative events are influencing the game rules, thus affecting the way games are played". (Ang, 2006:307) 
J ohnsenl (2003:33) e Walther (2004), assim como J uul (2005) e Salen \& Zimmerman (2003) veem as regras como o elemento que controla tanto a mecânica quanto a estrutura do jogo. Para Walther (2005) são ainda "formas que dirigem uma certa irreversibilidade da estrutura".

Estas observações também podem ser percebidas na tabela a seguir, que também nos permite ver que mesmo com vários autores considerando as regras como orientadoras e limitadoras das ações do jogador, ainda observadas em conjunto, essas características não são uma unanimidade e nem mesmo são citadas pela maioria dos autores, embora sejam as mais citadas. Ainda assim, entendemos essas características como essenciais na constituição e conceituação das regras. 


\begin{tabular}{|c|c|c|c|c|c|c|c|c|c|c|c|}
\hline CONCEITOS DE REGRAS & 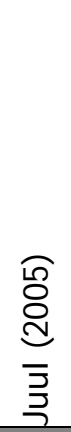 & 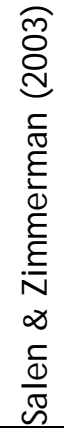 & 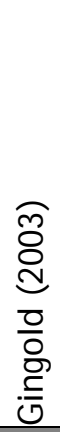 & 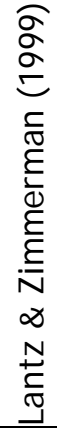 & 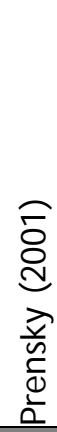 & 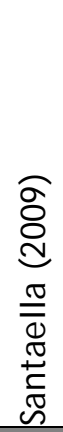 & 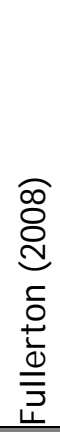 & $\begin{array}{l}\text { बे } \\
\text { त्र } \\
\circ \\
\stackrel{0}{0}\end{array}$ & 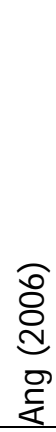 & 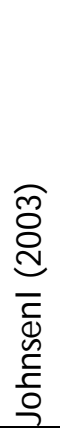 & 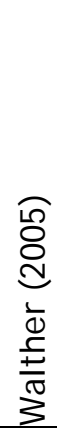 \\
\hline Orientam a ação do jogado & & & & & & & & & & & \\
\hline Limitam a ação do jogador & & & & & & & & & & & \\
\hline $\begin{array}{l}\text { Definem/ controlam a } \\
\text { estrutura }\end{array}$ & & & & & & & & & & & \\
\hline $\begin{array}{l}\text { Devem ser claras, de fácil } \\
\text { compreensão para o jogado }\end{array}$ & & & & & & & & & & & \\
\hline Não permitem ambiguidade & & & & & & & & & & & \\
\hline Dá valor aos estados de jog & & & & & & & & & & & \\
\hline $\begin{array}{l}\text { São fixas, acordadas e } \\
\text { passíveis de repetição }\end{array}$ & & & & & & & & & & & \\
\hline $\begin{array}{l}\text { Organiza em conjunto as } \\
\text { peças móveis }\end{array}$ & & & & & & & & & & & \\
\hline $\begin{array}{l}\text { Dá inteligibilidade e } \\
\text { plasticidade ao sistema }\end{array}$ & & & & & & & & & & & \\
\hline Definem o espaço narrativo & & & & & & & & & & & \\
\hline São leis & & & & & & & & & & & \\
\hline $\begin{array}{l}\text { São um sistema fechado e } \\
\text { determinista }\end{array}$ & & & & & & & & & & & \\
\hline $\begin{array}{l}\text { Colocam o jogador no } \\
\text { mundo do jogo }\end{array}$ & & & & & & & & & & & \\
\hline $\begin{array}{l}\text { Torna o jogo auto- } \\
\text { explorarório }\end{array}$ & & & & & & & & & & & \\
\hline Estabelecem desafios & & & & & & & & & & & \\
\hline $\begin{array}{l}\text { Podem proporcionar } \\
\text { experiências agradáveis ao } \\
\text { jogador }\end{array}$ & & & & & & & & & & & \\
\hline
\end{tabular}

Tabela 5. Conceitos de regras 


\subsubsection{Diferentes tipos de regras}

Alguns autores já propuseram diferentes classificações para as regras. Algumas destas classificações se aplicam a qualquer tipo de jogo, sejam eles esportivos, de tabuleiro ou eletrônicos, como as classificações de Frasca (1997), Salen \& Zimmerman (2003) e Järvinen (2003; 2005). Já Tosca (2003), Ang (2006) e J ohnsenl (2003) trazem classificações mais relacionadas aos jogos eletrônicos, aos videogames.

Apesar das classificações propostas serem bastante distintas, uma análise das mesmas nos permite observar que a grande maioria poderia ser agrupada em termos de regras que regulam o desenvolvimento do jogo e regras que definem o resultado do jogo, como na divisão proposta pro Frasca (1997:31-34), que as denomina regras de desenvolvimento e regras de resultado, respectivamente. Para o autor esta divisão se estabelece a partir da observação de suas funções.

Frasca ainda cria uma subdivisão para as regras de resultado, distinguindo-as entre regras de triunfo e regras de derrota, que servem para definir o resultado final dos jogos. Regras de triunfo são aquelas que definem como se vence um jogo. Para usarmos o exemplo dado por Frasca: "uma regra de triunfo do futebol seria: ao finalizar o tempo regulamentar, aquele que tiver mais gols será o vencedor" ${ }^{79}$. As regras de derrota, como o nome diz, definem a derrota em um jogo. Muitas vezes,

${ }^{79}$ Tradução nossa. Do original em espanhol: “Una regla de triunfo del fútbol sería: al finalizar el tiempo reglamentario, aquel que tenga más goles será el triunfador." (Frasca, 1997:32) 
estas são inversas às regras de triunfo (como no futebol, por exemplo). Mas existem casos em que não existem regras de triunfo já que a proposta do jogo é uma superação do próprio jogador. São os jogos que chamamos de passatempos. Um exemplo deste caso são os quebra-cabeças e jogos como o Cobra (um dos clássicos da Atari e comum em aparelhos de celular), em que as regras de derrota são: caso a cobra bata nas bordas da tela ou encontre parte do seu corpo, o jogo acaba.

As regras de desenvolvimento, de acordo com Frasca (1997:31-34) são as que não são de resultado, mas regem o desenrolar do jogo. Retomando o exemplo do futebol podemos citar as regras que determinam o que é uma falta, um escanteio, um penálti, quando a bola sai do campo, etc.

Ao analisarmos as categorizações propostas por outros autores, notamos que suas semelhanças apontavam para a categorização proposta por Frasca (1997) como a mais concisa. No entanto, sentimos a necessidade de subdivir o que o autor chamou de regras de desenvolvimento em duas outras categorias (regras regentes e regras orientadoras) para melhor acolher as diferenças apontadas pelos outros autores. 


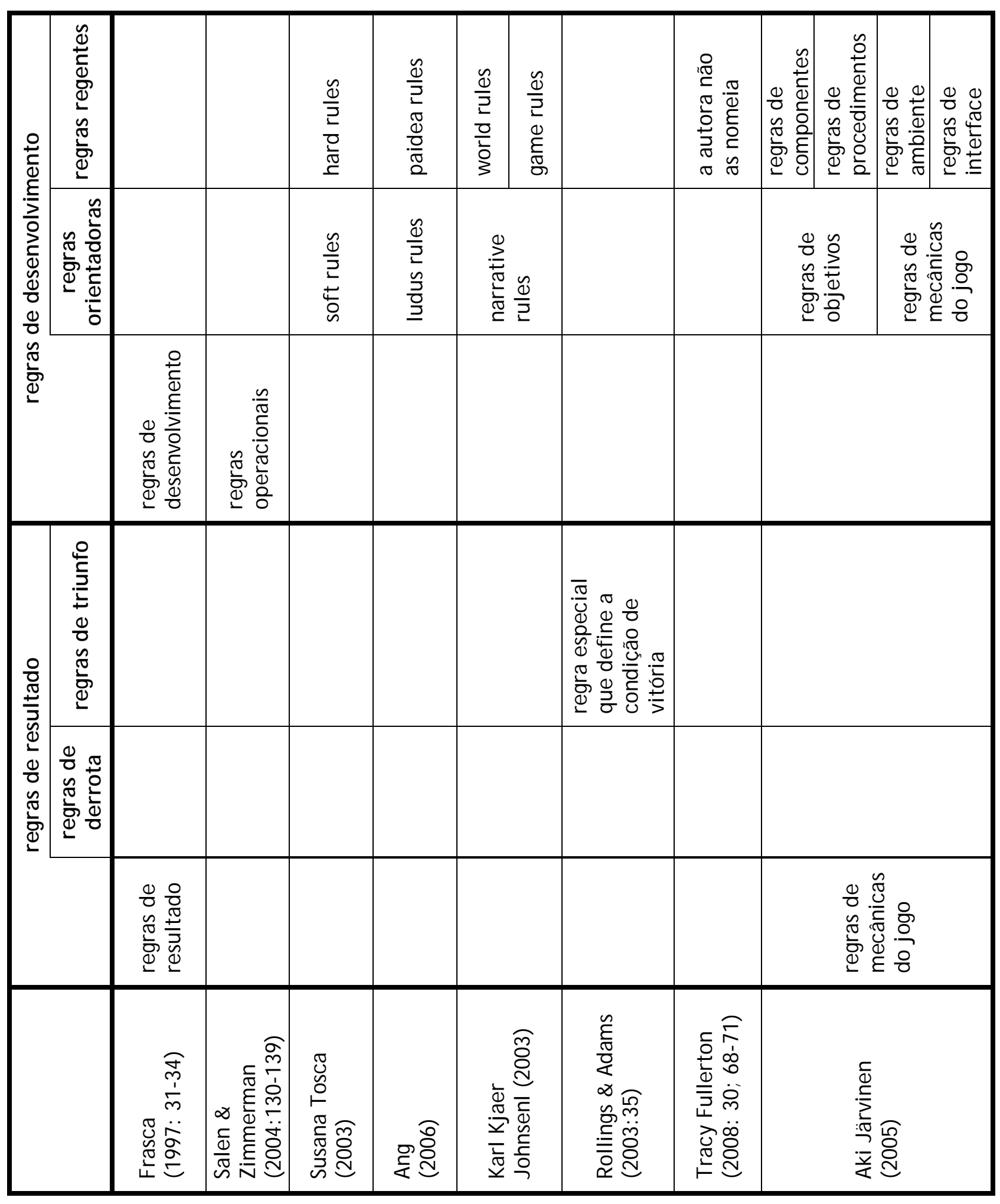

Tabela 6. Tipos de regras 
As regras regentes são as que regem o funcionamento do mundo do jogo e 0 comportamento do jogador em termos do que ele pode ou não fazer, e regras orientadoras, as que orientam suas ações em função de um objetivo, no sentido de permitir ao jogador estabelecer suas estratégias de jogo. A categorização passaria a ser assim representada:

\begin{tabular}{l|l}
\multirow{2}{*}{ regras de desenvolvimento } & regras regentes \\
\cline { 2 - 2 } & regras orientadoras \\
\hline regras de resultado & regras de triunfo \\
\cline { 2 - 2 } & regras de derrota
\end{tabular}

Esta tipificação das regras deve ser vistas à luz do que entendemos por regras, como sendo a parte do jogo responsável por determinar o que o jogador pode ou não pode fazer e o que acontece em virtude de suas escolhas, orientando sua ação no sentido de produzir resultados significativos no âmbito do jogo. Devem ser claras e não ambíguas de forma que sua compreensão contribua para que o jogador possa desenvolver um estilo pessoal de jogo em função de seu repertório e suas habilidades, contribuindo para que o jogo proporcione ao jogador uma experiência prazerosa e significativa.

Este entendimento pode ser observado quando propomos a observação de regras orientadoras como em parte responsáveis por permitir ao jogador criar suas próprias estratégias, que são em parte, o que ajudará a definir o estilo pessoal de cada jogador e só podem ser definidas em função de suas habilidades e repertórios. 
Passemos a uma análise mais detalhada das classificações propostas pelos diversos autores.

Salen \& Zimmerman (2003:130-139) dividem as regras em três tipos, que atuam conjuntamente e podem ser compreendidas em termos de níveis.

- Regras operacionais, que são as "regras do jogo", as regras que os jogadores seguem para poder jogar. "As regras operacionais direcionam 0 comportamento dos jogadores e são usualmente o tipo de regras impressas em instruções nos manuais dos jogos" ${ }^{80}$.

- Regras constitutivas são mais gerais, "são a estrutura formal implícita que existe 'debaixo da superfície' das regras apresentadas aos jogadores" ${ }^{81}$. São a parte lógica e matemática do jogo que, "apesar de conter a essência lógica, não explicam ao jogador como jogar" 82.

- Regras implícitas, que são as “'regras não escritas' de etiqueta e comportamento que os jogadores costumam adotar quando estão jogando" 83 . Diferentes jogos podem apresentar regras implícitas semelhantes. As regras

\footnotetext{
${ }^{80}$ Tradução nossa. Do original em inglês: "Operational rules direct the players' behavior and are usually the kinds of rules printed out in instructions and rulebooks for games." (Salen \& Zimmerman, 2004:139)

81 Tradução nossa. Do original em inglês: "The constituative rules of a game are the underlying formal structures that exist "below the surface" of the rules presented to players." (Salen \& Zimmerman, 2004:130)

82 Tradução nossa. Do original em inglês: "Although they contain the essential game logic, they do not explicitly indicate how players should enact these rules." (Salen \& Zimmerman, 2004:139)

${ }^{83}$ Tradução nossa. Do original em inglês: "Implicit rules are the 'unwritten rules'. of etiquette and behavior that usually go unstated when a game is played." (Salen \& Zimmerman, 2004:139)
} 
implícitas são também responsáveis pela manutenção do círculo mágico, uma vez que é o comportamento dos jogadores que reforça a existência deste espaço diferente da vida cotidiana.

São as regras que os autores denominam de operacionais que identificamos como as regras de desenvolvimento. Seus dois outros tipos de regras nos apresentam uma outra forma de entendermos as regras, mas não se encaixam na classificação que estamos apresentando.

Ainda de acordo como os autores, a identidade formal, que permite que distingamos um jogo de outro, emerge da relação entre as regras operacionais e as regras constitutivas do jogo, criando uma especificidade que faz com um jogo "seja este jogo e não aquele jogo".

Nos jogos digitais, há uma tendência a se confundir as regras com o código de programação do jogo. Embora o código contenha as regras, estas são mais do que a programação que a engendra. Para Salen \& Zimmerman (2003:149) "regras são ferramentas abstratas para pensarmos a respeito da estrutura formal de um jogo e não estão, necessariamente, manifestas literalmente no código" ${ }^{84}$.

\footnotetext{
${ }^{84}$ Tradução nossa. Do original em inglês: "Rules are abstract tools for thinking about the formal structure of a game and are not necessarily literally manifest in code." (Salen \& Zimmerman, 2004:149)
} 
Retomando os tipos de regras propostos por Salen \& Zimmerman (2003:130-139), apresentados acima, podemos ver como cada nível se apresenta nos videogames. Cabe aqui ressaltar que os autores consideram que determinar que parte do programa pertence a cada tipo de regra nem sempre é muito simples, por serem os programas dos jogos obj etos complexos e compostos por diversas camadas.

- Nos videogames, as regras operacionais estão diretamente relacionadas ao comportamento do jogador e sua interação com o jogo, incluindo a maneira como o jogador responderá às demandas do jogo utilizando dispositivos de entrada como teclado, mouse ou joystick.

- As regras constitutivas estão relacionadas aos eventos internos, aqueles relativos ao processamento das escolhas do jogador e, podemos dizer, fazem parte do código de programação do jogo.

- Os videogames compartilham muitas regras implícitas com jogos não digitais. Mas além destas, somam-se as características próprias de cada plataforma, como o uso já padronizado das mesmas teclas do teclado para a execução de movimentos semelhantes em jogos diversos.

Os autores consideram ainda que compreender estes níveis de regras pode ajudar a construir jogos que proporcionem uma experiência mais significativa para os jogadores. 
Tosca (2003), buscando descobrir como as missões funcionam em jogos, o que os torna interessantes ou enfadonhos, e de como isso pode estar relacionado ao design dos videogames, observa que o formato de busca ou missão permite uma contextualização das ações do jogo em uma história mais ou menos significativa, que pode ou não ser vital para a experiência do jogador ao jogar.

Para a autora a causalidade dos eventos se apresenta em dois níveis: "um semântico (como/ porque as ações se conectam); e um estrutural (plano de ações, interações de objetos e eventos)" e que estes dois níveis contribuem para o envolvimento do jogador como parte de sua experiência ${ }^{85}$. A autora, em seu artigo The quest problem in computer games foca sua análise exclusivamente nos jogos que contenham elementos narrativos ${ }^{86}$, no entanto, a classificação por ela proposta, dividindo as regras em regras rígidas (hard rules) e regras maleáveis (soft rules), pode ser estendida para jogos que não contenham elementos narrativos.

\footnotetext{
${ }^{85}$ Tradução nossa. Do original em inglês: “I earlier defined quests as a way of structuring events in games, and explained that they incarnate causality at two levels: a semantic one (how/ why actions are connected); and a structural one (plan of actions, interaction of objects and events)." (Tosca, 2003)

${ }^{86}$ Tosca enfatiza que "ferramentas literárias podem ser úteis para analisar elementos narrativos em certos jogos (...) porque existem muitos jogos que não têm elemento narrativo algum".
} 
Para Tosca (2003), regras rígidas são as regras que fazem parte do mundo do jogo, ou seja, "as propriedades dos objetos e os comportamentos e dinâmica do gameplay, incluindo o objetivo final do jogo". Já as regras maleáveis são os

objetivos concretos em pequenas sequências de ações, de certa forma, o modo como as regras rígidas são particularmente implementadas em curtas sequências. (...) Poderíamos dizer também que regras rígidas são gerais, as regras maleáveis são particulares ${ }^{87}$.

Quando relacionamos estas categorias de Tosca a por nós proposta devemos observar que para a autora as regras maleáveis (que relacionamos às regras orientadoras) incluem apenas os objetivos e ações desenvolvidas a curto prazo, ficando o objetivo final do jogo incluso nas regras rígidas. Mas por serem as regras maleáveis mais particulares as consideramos mais orientadoras das ações do jogador, enquanto as regras rígidas, por serem mais gerais acabam por reger 0 mundo do jogo e o comportamento do jogador.

Partindo das distinções estabelecidas por Tosca e Frasca ${ }^{88}$, Ang (2006:310-313), que entende os videogames "como tendo duas camadas, uma abstrata e uma narrativa,

\footnotetext{
${ }^{87}$ Tradução nossa. Do original em inglês: “I propose that the hard rules are the rules making up the game-world, namely, objects properties and behaviours and gameplay dynamics, including the final goal of the game. The soft rules would in this approach be the concrete objectives in smaller strings of actions, in a way, how the hard rules are particularly implemented in short sequences that the player can take individually." (Tosca, 2003)

${ }^{88}$ Frasca (2001) propõe usar os termos de Caillois alterando levemente os seus significados, definindo paidea como os jogos que não definem ganhadores e ludus como os que definem ganhadores e perdedores. Ver mais informações a respeito na páginas 19 e 20.
} 
que são ligadas pelas regras do jogo" ${ }^{89}$, divide as regras em regras ludus, que expressam o que deve ser feito nos jogos; e regras paidea, que expressam como devem ser executadas as ações no ambiente do jogo.

E, da divisão das regras em regras paidea e regras ludus, Ang (2006:310-313) propõe outros subconjuntos. Assim as regras paidea subdividem-se em

- Regras paidea simbólicas (symbolic paidea rules), que definem o que os jogadores podem e não podem fazer no espaço virtual. Também definem o mapeamento das ações físicas para as ações virtuais. Muitos destes mapeamentos são convencionados e podem ser aprendidos.

- Regras paidea semânticas (semantic paidea rules), responsáveis por definir a causalidade das ações: como as ações estão conectadas e quais são as consequências de uma ação no mundo virtual.

E as regras ludus em

- Regras ludus intrínsecas (intrinsic ludus rules), que contribuem indiretamente para vencer um jogo. Precisam ser construídas pelo jogador ou introduzidas no jogo de tempos em tempos para que o jogador possa alcançar a condição de vencer o jogo.

\footnotetext{
${ }^{89}$ Tradução nossa. Do original em inglês: "Video games are thus divided into two layers: the abstract and the narrative layer." (Ang, 2006:314)
} 
- Regras ludus extrínsecas (extrinsic ludus rules), cuja contribuição para vencer um jogo é direta. Aparecem explicitamente no jogo como o objetivo final.

$\mathrm{Na}$ correlação que estabelecemos, consideramos a divisão das regras com suas respectivas subdivisões como um todo, ficando as regras paidea relacionadas às regras regentes e as ludus, às orientadoras.

Para J ohnsenl (2003:33-35) que considera que são as regras que controlam tanto a mecânica quanto a estrutura do jogo, estas podem ser divididas em três categorias: regras de mundo (world rules), regras narrativas (narrative rules) e regras do jogo (game rules). As regras de mundo estão relacionadas à lógica e aos mecanismos do mundo do jogo. As regras narrativas são mais específicas e têm qualidades semânticas. Já as regras do jogo são regras narrativas sem significados narrativos, estão relacionadas ao jogo: como o jogo é jogado. Para o autor, são as regras do jogo que definem o gameplay.

Consideramos que tanto as regras de mundo (world rules) quanto as regras do jogo (game rules) podem ser classificadas como regras regentes, responsáveis por regulamentar as ações do jogador. Já as regras narrativas (narrative rules) são regras orientadoras, uma vez que, para o autor, estas são equivalentes às regras maleáveis (soft rules), de Tosca (2003). Convém ainda ressaltar que J ohnsenl (2003) considera suas regras de mundo similares às regras rígidas (hard rules) de Tosca e 
inclui as regras do jogo como complementares e independentes de relação com as estabelecidas por Tosca.

Para Fullerton (2008: 30; 68-71) algumas regras definem os objetos (enquanto partes móveis do jogo, como cartas e peões em jogos analógicos e os personagens e objetos que o jogador pode manipular e/ ou controlar nos videogames) e os conceitos do jogo. São regras que determinam efeitos (if... else...) e são úteis para gerar variações no gameplay, embora também possam ser usadas para colocar 0 jogo de volta no caminho certo. Outras limitam o comportamento do jogador e proíbem manifestações reativas, definindo o que pode e o que não pode ser feito no âmbito do jogo. Estas regras também podem delimitar o campo ou área de ação do jogo (onde o jogo acontece).

Estas observações sobre as funções e características específicas que Fullerton aponta nas regras, para nós, estão todas relacionadas às regras regentes, uma vez que a autora não aponta nenhum elemento que as observe como responsáveis pelo desenvolvimento de estratégias, que guiarão o jogador até o final do jogo, rumo ao seu objetivo.

Já Rollings \& Adams (2003:35) apontam a existência de regras com funções análogas às regras de resultado de Frasca, no entanto, os autores se referem a elas como as regras que criam "condições de vitória" para o jogo. 
Incluída nas regras da maioria (mas não de todos) os jogos há uma regra especial que define a condição de vitória: um estado de coisas em que um ou mais jogadores podem ser declarados vencedores. Normalmente, o primeiro jogador a alcançar a condição de vitória é o vencedor e os outros são os perdedores ${ }^{90}$.

Os autores, baseados nesta condição de vitória, dividem os jogos em competitivos (onde os jogadores competem entre si para definir um único vencedor), colaborativos (os jogadores cooperam entre si para alcançar esta condição de vitória), os jogos de times (onde um grupo de jogadores forma uma equipe que compete contra outras equipes).

E além desta definição de tipos de jogos, Rollings \& Adams também reconhecem que além da condição de uma vitória, muitos jogos têm uma ou mais condições de perda. Assim como para Frasca, que chama esta condição de regra de derrota, a primeira condição de perda está implícita: se você não vence, você perde. E também reconhecem que existem jogos que não possuem condição de vitória, possuindo apenas condição de derrota.

Lembram que alguns videogames não têm condição de vitória, como em jogos de construção e simulações como Sim City (Eletronic Arts Games, 1989), que não estabelecem metas e condições de vitória e que estas podem ser estabelecidas pelo

\footnotetext{
${ }^{90}$ Tradução nossa. Do original em inglês: "Included with the rules of most (but not all) games is a special rule that defines the victory condition: a state of affairs in which one or more players are said to be the winner. Usually, the first player to achieve the victory condition is the winner and the others are the losers." (Rollings \& Adams, 2003:35)
} 
próprio jogador ou simplesmente não são estabelecidas e o jogador apenas passa algum tempo "brincando com o jogo sem tentar conseguir alguma coisa em especial". A este tipo de jogos, os autores chamam de software-brinquedo ${ }^{91}$.

Encontramos duas classificações de regras feitas por J ärvinen. Na primeira, em 2003, o autor elenca cinco tipos de regras:

- Regras de componentes (Component rules) - como sendo as regras que regem os componentes do jogo, indicando seu valor, número, status, etc e suas funções, como por exemplo, seu papel dentro de uma mecânica.

- Regras de processo (Procedure rules) - que determinam a relação entre os procedimentos e os outros elementos, permitindo definir as mecânicas do jogo e suas consequências. Definem também como o sistema de jogo fornece ao jogador o feedback de suas ações.

- Regras de ambiente (Environment rules) - são as que definem o ambiente do jogo: os limites físicos de componentes e dos procedimentos.

- Regras de temas (Theme rules) - ditam como o tema do jogo é implementado.

\footnotetext{
${ }^{91}$ Tradução nossa. Do original em inglês: "Some computer games have no victory condition. These are often construction and management simulations such as Sim City. Rather than trying to 'win' by achieving the victory condition, you can set your own goals for what you're trying to achieve. Or, you can just play around with the game without trying to achieve anything in particular. (Sim City also has some scenarios with victory conditions.) These kinds of games are sometimes referred to as software toys." (Rollings \& Adams, 2003:35)
} 
- Regras de interface (Interface rules) - são as responsáveis por definir como a interface é usada para aprovar procedimentos e mecanismos dentro do ambiente de jogo, complementando com as regras a prestação de informações ao jogador sobre o seu progresso (J ärvinen, 2003: 77-78).

A segunda classificação feita por autor faz parte de notas de aula encontradas em um artigo de Lopes \& Roque (2005). Nesta classificação o autor eliminou as regras de tema e incorporou outras duas, totalizando assim os seis tipos abaixo. As regras que permanecem iguais à classificação anterior são apenas mencionadas, indicando que seu papel permanece o mesmo da tipificação anterior.

- Regras de objetivos (Goal rules) - definem o objetivo do jogo.

- Regras de componentes (Component rules).

- Regras de processo (Procedure rules).

- Regras de Mecânica do J ogo (Game Mechanics Rules) - especificam quais ações do jogador são permitidas. Também especificam as consequências da mecânica (levando a um determinado procedimento, por exemplo) e os critérios de sucesso / falha.

- Regras de ambiente (Environment rules).

- Regras de interface (Interface rules).

Järvinen observa em seu artigo de 2003 que apenas as regras de componentes e de processo estarão obrigatoriamente presentes em todos os jogos e que os demais tipos podem ser encapsulados a estes obedecendo a ordem de sua tipificação. 
Observamos que na classificação proposta em 2005, o autor mantém as regras de ambiente e de interface como opcionais, apontando as outras como obrigatórias. Vale ainda destacar que as regras de interface estão tipicamente relacionadas aos videogames.

Consideramos a segunda classificação proposta por Järvinen, em 2005, mais madura, por isso a adotamos na comparação que estabelecemos com outras classificações e, propomos que as regras de componentes, de procedimentos, de ambiente e de interface devam ser consideradas como regras regentes (de acordo com nossa proposição). Embora o autor considere as regras de ambiente e de interface como opcionais esta distinção não interfere na nossa classificação, uma vez que, quando presentes, assumem esta função de determinar o funcionamento do jogo.

As regras de objetivos se encaixam na nossa definição de regras orientadoras, enquanto as regras de mecânica de jogo podem ser classificadas tanto como orientadoras quanto como regras de resultado, uma vez que suas especificidades abarcam funções destas duas esferas.

Do que foi dito acima, concluímos que as regras são elementos que organizam 0 jogo, e consequentemente, a experiência do jogador. As regras definem as restrições que o jogo impõe e as ações potenciais do jogador e parte do desafio está exatamente em alcançar um resultado dentro dos limites estabelecidos. São 
estes limites também que definem as especificidades que permitem distinguir um jogo de outro.

Compreender o papel das regras e das funções de cada um dos seus tipos permite ressaltar sua importância para a criação de jogos originais, diferente daqueles que trazem apenas adaptações de regras e layouts. Do jogo Tetris, por exemplo, encontramos diversas versões, a maioria faz apenas modificações no layout, como 0 Quatrix, desenvolvido por Paul Neave. Mas existem outras versões, como as comemorativas aos 25 anos de lançamento do jogo (disponíveis em http://www.tetrisfriends.com/), que trazem variações, inclusive criando opções multiplayer para até 6 jogadores, como o Battle 6P.

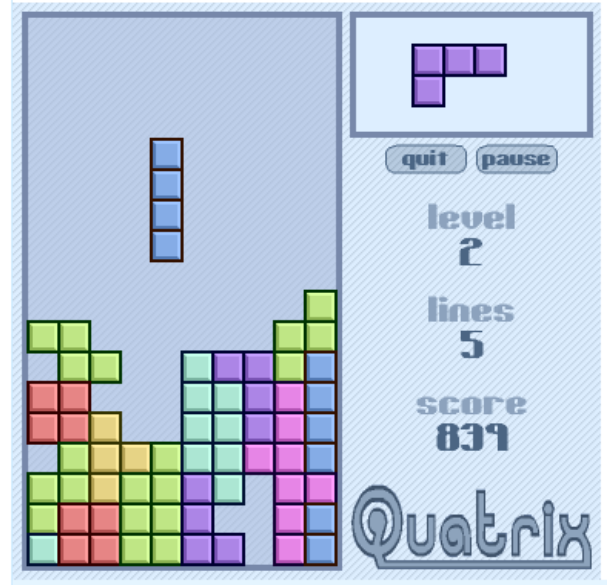

Figura 7. Quatrix

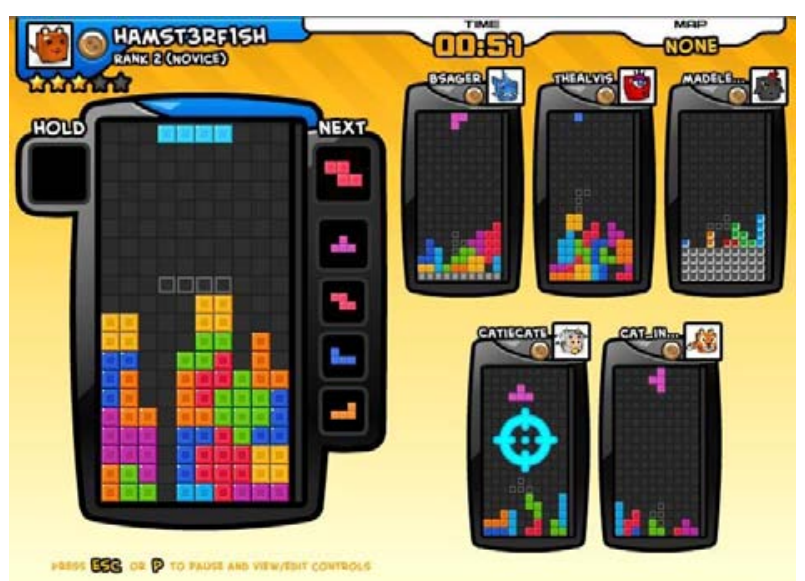

Figura 8. Battle 6P

Outro exemplo de jogo com diversas versões é o game casual Bejeweled (PopCap Games, 2001), que inclusive podemos ver como uma derivação do jogo analógico Lig-4, lançado no Brasil pela Estrela, em 1976 (sendo ainda fabricado e 
comercializado com o mesmo nome). Em Lig-4 o objetivo é ser o primeiro a conseguir alinhar quatro fichas da mesma cor (na horizontal, vertical ou diagonal). Bejeweled é o mais conhecido dos jogos "de combinação de cores" ou "match 3", como costumam ser definidos nos sites para download de games, mas existem diversos outros com pouquíssimas variações, a maioria, com variações apenas no layout, como J ewel Match (iWin, 2007), Adventure Match (Free Game Pick, 2008) ou Crystal Battle (Arcade Space, 2009). Estes jogos, em geral, têm por objetivo alinhar três peças da mesma cor ou tipo, ao invés das quatro do Lig-4. 0 alinhamento, no caso das adaptações eletrônicas, leva a eliminação dessas peças que são substituídas por outras, tais como quando alinhamos os elementos em Tetris.

Nestes exemplos podemos observar que na comparação entre os jogos digitais e 0 analógico Lig-4, o que se mantém são os objetivos dos jogos: alinhar um determinado número de peças, por isso falamos em derivação e não apenas em adaptação para o suporte digital. Inclusive porque as regras e mecânicas apresentam-se diferentes. No Lig-4 os jogadores, cada um na sua vez, acrescenta uma peça ao tabuleiro, tentando ao mesmo tempo alinhar quatro peças de sua cor e evitar que 0 adversário o faça. 0 primeiro que conseguir alinhar as suas peças vence o jogo. Caso todo o tabuleiro se complete sem que nenhum jogador alcance 0 objetivo do jogo, este é considerado empatado. 


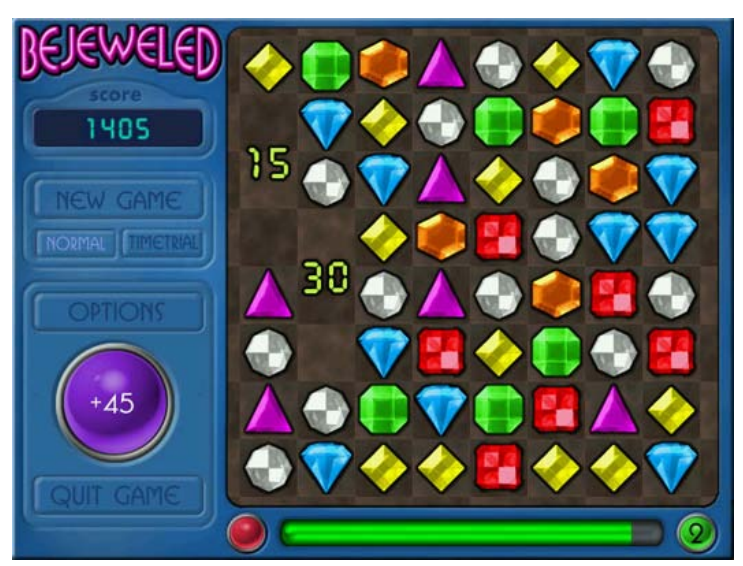

Figura 9. Bejeweled

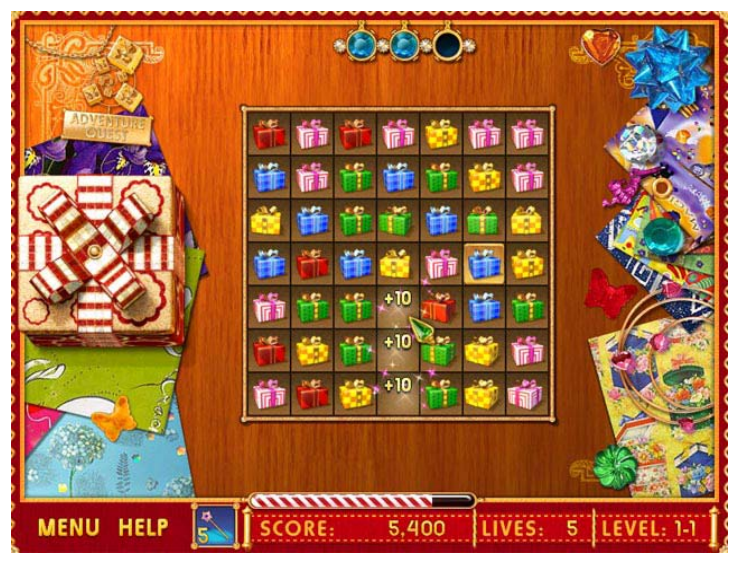

Figura 11. Adventure Match

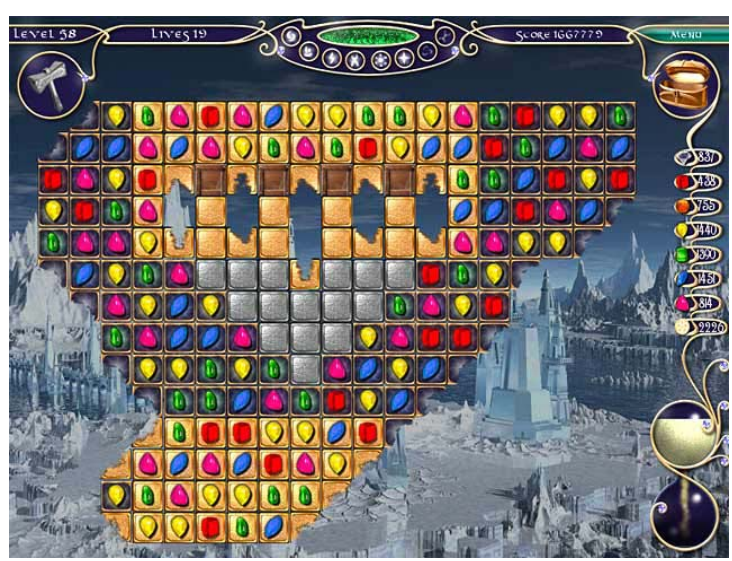

Figura 10. J ewel Match

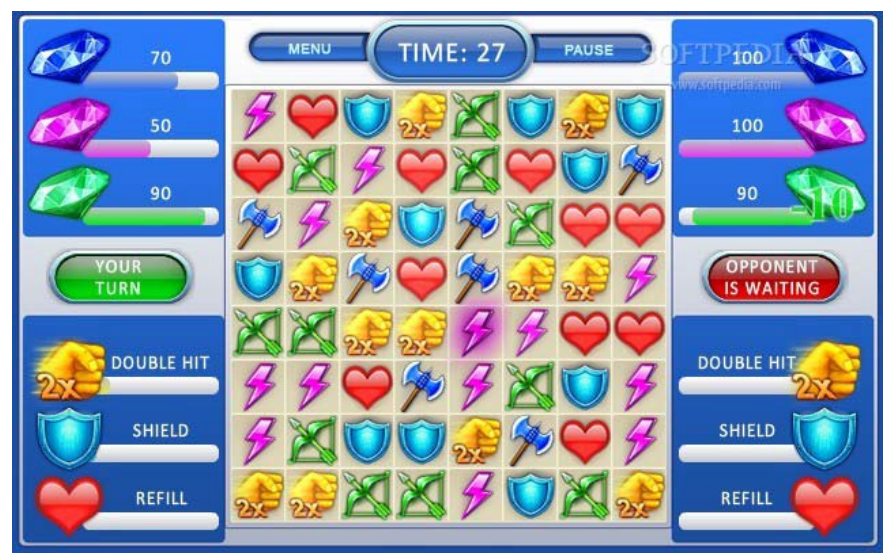

Figura 12. Crystal Battle

Nos jogos eletrônicos citados, as regras de desenvolvimento são as mesmas, o tabuleiro apresenta-se todo preenchido e para alinhar três peças semelhantes (ou da mesma cor) na vertical ou horizontal (ao contrário do Lig-4, o alinhamento na diagonal não é considerado), o jogador deve trocar duas peças vizinhas de lugar, clicando sobre elas. Não é permitido trocar de lugar peças que não estejam nas casas adjacentes e essa adjacência não se aplica a casas diagonais. 
Também as regras de resultado são semelhantes, há uma quantidade necessária de alinhamentos para se vencer o jogo, dentro de um período de tempo. Se este tempo acabar antes do total de alinhamentos ter sido completado, o jogador perde. 0 único jogo que apresenta uma variação na mecânica é Crystal Battle, que é jogado em duplas, e por isso é disputado em turnos (como o Lig-4), mas os movimentos e a forma de se definir o resultado se mantêm os mesmo dos demais jogos eletrônicos.

Outro jogo destes do tipo "match 3", mas com variação na mecânica é o Monkey Trouble 2 (Crystal Squid, 2009), onde o jogador, para alinhar as três peças, desloca toda a fileira arrastando a peça selecionada para gerar esse alinhamento.

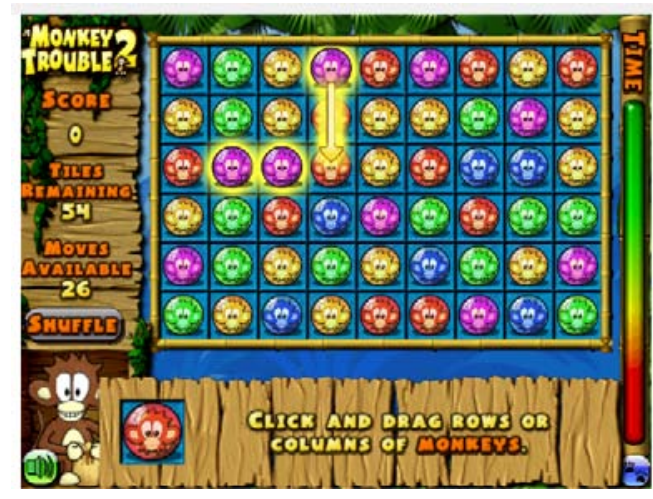

Figura 13. Monkey Trouble 2

Dessa digressão e exemplos, podemos claramente ver o papel central das regras. Uma vez estabelecidas e bem compreendidas, permitem variações que levam a jogos razoavelmente diferentes, o que mostra que, numa hierarquia de conceitos que norteiam os jogos, elas ocupam de fato posição muito elevada. 


\subsection{Gameplay}

O termo gameplay muitas vezes aparece traduzido por jogabilidade, um termo que ainda não se encontra em nenhum dicionário de língua portuguesa. Mesmo assim, em sites e revistas especializadas, o termo é frequentemente utilizado. Muitos dos sites e revistas especializadas em games valem-se do termo sem dar uma definição exata, como que partindo do pressuposto de se tratar de um termo corriqueiro. A definição mais frequentemente encontrada (em sites, listas de discussão e até mesmo em artigos de revistas da área) é atribuída à Wikipedia mas, para se ter uma ideia da complexidade do termo, nem mesmo esta definição encontra-se mais online ${ }^{92}$. A citada definição era:

J ogabilidade é a virtude que um jogo possui para ser fácil e intuitivo de se jogar. Quanto mais rápido o jogador se sentir confortável com os comandos do jogo e seu ambiente, mais conceituada é a jogabilidade. Existe ainda outro conceito para jogabilidade, geralmente aplicado por revistas especializadas, que pode ser entendido como a maneira em que o jogador interage com a mecânica de jogo. Neste caso, uma jogabilidade mais complexa não significa dificuldade de interação entre jogador e jogo, mas a profundidade com que isto ocorre, na forma de enredo mais elaborado, variedade de ação e quebra-cabeças complexos, por exemplo93.

\footnotetext{
92 Essa definição foi eliminada, entre outros motivos, por tratar-se "dum adjetivo relativo a jogos eletrônicos, coisa que não cabe aqui na wiki" e porque a "palavra nem sequer existe em nenhum dicionário de língua portuguesa (pelo menos ainda não descobriram um que a contivesse). Sem fontes, apenas com blogs e fóruns, é pesquisa inédita, e isso não cabe na Wikipédia". Disponível em: বttp:// pt. wikipedia.org/ wiki/ Wikipedia:Páginas_para_eliminar/J ogabilidade>. Acesso em: 06 jul. 2009. ${ }^{93}$ Definição atribuída à Wikipedia, publicada na matéria "Advergames: 0 jogo on-line das marcas", da revista Webdesign, Rio de Janeiro, ano 4, n. 46, p. 46-50, outubro 2007.
} 
Esta definição não se sustentou na Wikipedia, entre outros motivos, por se tratar de um termo ainda não dicionarizado. Ainda assim, a título de exercício, podemos tomá-la como ponto de partida para compará-la às diversas definições do termo gameplay encontradas.

Diferentemente do termo jogabilidade, o termo gameplay já pode ser encontrado em alguns (mesmo que ainda poucos) dicionários de língua inglesa. O Longman Dictionary of Contemporary English e o English Collins Dictionary definem gameplay como o modo como um jogo de computador é projetado e as habilidades necessárias para jogá-lo. Esta definição se assemelha à primeira parte da definição de jogabilidade citada acima, que diz que jogabilidade é "a virtude que um jogo possui para ser fácil e intuitivo de se jogar", e está bastante relacionada à curva de aprendizagem de um jogo ${ }^{94}$.

Já o Encarta ${ }^{\circledR}$ World English Dictionary [North American Edition] define gameplay como o valor de entretenimento de um jogo de computador, incluindo aspectos tais como interface do usuário e game design; e o dicionário Inglês-Inglês do Babylon, como o passo a passo executado através de um jogo, um ciclo de um determinado jogo (especialmente em um jogo de computador). Aqui observamos que a definição do Encarta não se assemelha às definições dadas de jogabilidade, enquanto a definição do dicionário Inglês-Inglês do Babylon assemelha-se à segunda parte da

\footnotetext{
${ }^{94}$ A curva de aprendizagem refere-se ao tempo que o jogador leva para aprender os comandos do jogo e sentir-se confortável com eles.
} 
definição do Wikipedia, que diz que jogabilidade pode ser entendida "como a maneira em que o jogador interage com a mecânica do jogo".

Tais definições dicionarizadas, no entanto, não são suficientes para o entendimento do real conceito do termo, até mesmo porque podemos observar que não apresentam uma unanimidade com relação ao conceito. A mesma falta de unanimidade se observa entre os diversos autores que apresentam suas definições, sem, no entanto, chegarem a um consenso.

\subsubsection{O conceito de gameplay por diversos autores}

Rollings \& Adams (2003:199-201), em seu livro Andrew Rollings and Ernest Adams on Game Design, abrem o capítulo sobre gameplay falando da dificuldade de conceituação do termo. Os autores apontam que qualquer designer concordaria que o "gameplay é o núcleo do jogo", mas que, no entanto, não há uma definição "universalmente aceita" para o termo. Eles alegam que "cada criador tem sua própria definição pessoal de gameplay, formada a partir da exposição a muitos exemplos [que ilustram ao se tentar explicar o que é gameplay] ao longo de sua carreira" 95. Partindo de uma declaração de Sid Méier que "uma vez definiu

\footnotetext{
${ }^{95}$ Tradução nossa. Do original em inglês: “Any game designer should agree that gameplay is the core of the game. Given an ideal world, designers would probably claim that gameplay should be put above all other considerations. (...) There's just one problem with this: There is no universally accepted definition of gameplay. Gameplay is an important, if nebulous, concept. Many times during discussions of games, we have heard comments such as, 'This has great gameplay', followed by a detailed description of the particular aspect of the game." (Rollings \& Adams, 2003: 199-201)
} 
gameplay como "uma série de opções interessantes'", os autores elaboram sua própria definição. Para os autores, gameplay é "uma ou mais séries de desafios em uma relação causal, num ambiente de simulação" ${ }^{96}$.

Rollings \& Morris (2003:39; 60-62), ao apresentar os elementos de um jogo, dizem que 0 gameplay "incentiva 0 jogador a empregar estratégias" ${ }^{97}$ para desenvolver bem sua atuação no jogo e chegar a parâmetros específicos e implica escolhas interessantes por parte do jogador. Para os autores "um jogo bem concebido não pode ser vencido sem estratégia. E estratégia manifesta-se como uma série de opções interessantes" ${ }^{98}$.

Feil \& Scattergood (2005:9) entendem o gameplay como o conjunto de elementos que torna um jogo divertido. "Existem tantos sabores de gameplay quanto existem jogos. Quando você estiver criando seu jogo, você terá que identificar qual é o seu gameplay e torná-lo tão divertido quanto possível" ${ }^{99}$.

\footnotetext{
${ }^{96}$ Tradução nossa. Do original em inglês: "Sid Meier once defined gameplay as "a series of interesting choices." This is an excellent starting point and forms the basis of our definition of gameplay. We take this statement one step further with our formal definition of gameplay: / One or more causally linked series of challenges in a simulated environment." (Rollings \& Adams, 2003:201)

97 Tradução nossa. Do original em inglês: "gameplay encourages the player to employ strategies." (Rollings \& Morris, 2003:39)

${ }^{98}$ Tradução nossa. Do original em inglês: "a well-designed game cannot be won without strategy. And strategy manifests itself as a series of interesting choices." (Rollings \& Morris, 2003:62)

99 Tradução nossa. Do original em inglês: "There are as many flavors of gameplay as there are games. When you're creating your game, you'll have to identify what your gameplay is and make it as fun as possible." (Feil \& Scattergood, 2005:9)
} 
Para Howland (1999), a experiência do jogador é bastante importante na definição do conceito, já que o autor define gameplay em função das "interações significantes que 0 jogador tem com o jogo" 100 .

No artigo The Gameplay Gestalt, Narrative, and Interactive Storytelling, Lindley (2002:2-6) explora a ideia de gameplay como um "processo de formação de uma gestalt interativa" ${ }^{101}$ e inclui as regras como elemento importante para definição do gameplay. Para o autor, nos videogames, gameplay se refere às atividades realizadas no âmbito de um quadro de regras acordadas que, direta ou indiretamente, contribuem para alcançar metas.

Para Assis (2007:17-18) é o conceito de gameplay que distingue o videogame dos outros meios de expressão. Para o autor, videogames

são interativos como qualquer coisa na vida real, que reage somente depois de nossa intervenção; também são expressivos, podendo ter história e roteiro, como filmes; têm interface como qualquer programa ou qualquer painel de um aparelho; mas só eles têm essa característica que faz com que o balanço entre as possibilidades de interação, o desenvolvimento da tensão e a experiência exploratória se torne algo imersivo.

Assis ainda observa que é "o conjunto de decisões que se soma no gameplay determina se a experiência será imersiva e divertida ou entediante". Isto, em

100 Tradução nossa. Do original em inglês: "Gameplay can be defined as the meaningful interactions the player has with the game." (Howland, 1999)

101 Tradução nossa. Do original em inglês: "this paper explores an alternative conception of gameplay as an interactive gestalt formation process." (Lindley, 2002:2) 
função de balanço entre regras fixas e flexibilidade para permitir ao jogador desenvolver um estilo pessoal de jogo.

Arsenault \& Perron (2009:109), ao conceituar a atividade de jogar, definem gameplay como o ponto de encontro de duas entidades distintas, o jogo e 0 jogador ${ }^{102}$, e o entendem como um espectro de possíveis ações e reações que é gerado tanto pelo jogador quanto pelo próprio jogo.

O gameplay, para Sicart (2008), é definido pela mecânica do jogo. Sendo esta definida por ele como os métodos invocados pelos agentes (humanos ou não), projetados para interagir com o mundo do jogo.

Já Tom Heaton (2006), em seu artigo A Circular Model of Gameplay, não se preocupa em dar uma definição, mas em desenvolver um modelo teórico que mostre como o gameplay funciona na prática. Para o autor o gameplay decorre da interação do jogador com o jogo, não numa interação randômica, mas como um fluxo circular de informação que vai do jogo ao jogador e vice-versa ${ }^{103}$.

\footnotetext{
102 Tradução nossa. Do orginal em inglês: "The simplest way to conceptualize the gaming activity is to see the game and the gamer as two separate entities meeting at a junction point, which is commonly referred to as "gameplay'". Arsenault \& Perron (2009:109)

103 Tradução nossa. Do original em inglês: "Gameplay occurs when the player interacts with the game. But in this model, the interaction is not random, it is a flow of information from the game to the player and from the player back to the game. The interaction is circular - the flow is always in the same direction and no stage can be missed". Heaton (2006).
} 
As semelhanças entre estas definições podem ser observadas na tabela abaixo.

\begin{tabular}{|c|c|c|c|c|c|c|c|}
\hline \multirow[b]{2}{*}{ GAMEPLAY } & \multicolumn{4}{|c|}{$\begin{array}{c}\text { Experiência proporcionada } \\
\text { ao jogador }\end{array}$} & \multicolumn{3}{|c|}{ Interação com o jogo } \\
\hline & 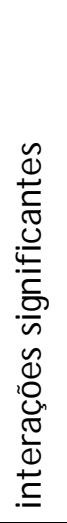 & 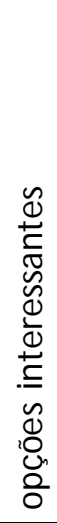 & 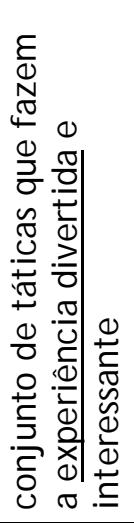 & 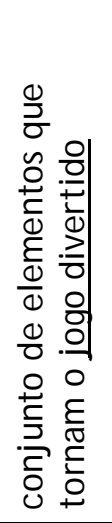 & 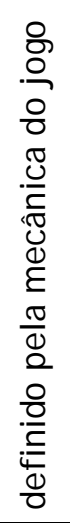 & 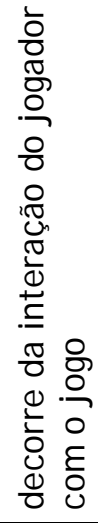 & 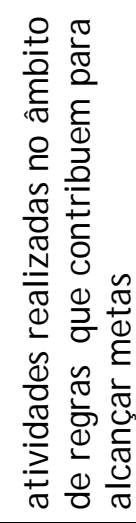 \\
\hline \multicolumn{8}{|l|}{ Sid Méier } \\
\hline \multicolumn{8}{|c|}{ Rollings \& Adams (2003) } \\
\hline \multicolumn{8}{|c|}{ Rollings \& Morris (2003) } \\
\hline \multicolumn{8}{|c|}{ Howland (1999) } \\
\hline \multicolumn{8}{|c|}{ Feil \& Scattergood (2005) } \\
\hline \multicolumn{8}{|c|}{ Arsenault \& Perron (2009) } \\
\hline \multicolumn{8}{|l|}{ Lindley (2002) } \\
\hline \multicolumn{8}{|l|}{ Assis (2007) } \\
\hline \multicolumn{8}{|l|}{ Sicart (2008) } \\
\hline Heaton (2006) & & & & & & & \\
\hline
\end{tabular}

Tabela 7. Definições de gameplay

Podemos destacar que a experiência proporcionada ao jogador e a interação com o jogo são os principais pontos em torno dos quais as definições apresentadas se agrupam. Os destaques dados aos termos "experiência divertida" e "jogo divertido" são grifos nossos. 
Desta série de definições apresentadas, podemos observar que a experiência que 0 jogo proporciona ao jogador é o ponto principal da maior parte delas, apresentadas como interações significantes (Howland 1999), uma série de opções interessantes (Sid Méier; Rollings \& Adams 2003), conjunto de táticas que fazem a experiência divertida e interessante (Assis 2007) ou conjunto de elementos que tornam o jogo divertido (Feil \& Scattergood 2005).

Podemos notar também que o que Sid Méier chama de "opções interessantes" é uma das palavras-chave para o entendimento do conceito de gameplay, uma vez que este conceito é utilizado também por Rollings \& Morris (2003), e também pode ser deduzido das definições de Rollings \& Adams (2003), Assis (2007) e Sicart (2008).

Rollings \& Adams (2003) partem da definição de Méier e falam em "série de desafios numa relação causal" que podem ser interpretados como opções interessantes, pois os desafios pressupõem escolhas e escolhas sempre são feitas entre ao menos duas opções. Assis (2007) fala em "conjunto de táticas" que são elaboradas a partir das opções do jogador. E, se para Sicart (2008), o gameplay é definido pela mecânica do jogo, esta define os desafios e escolhas que serão apresentadas ao jogador, ou seja, as opções que Ihe são dadas.

Outro ponto comum que pode ser observado é o fato do gameplay ser decorrente da interação do jogador com jogo, como para Arsenault \& Perron (2009) e Heaton 
(2006) que vê esta interação como um fluxo circular de informação que vai do jogo ao jogador e vice-versa. Para Sicart (2008) o gameplay é definido pela mecânica do jogo, enquanto para Lindley (2002) refere-se às atividades realizadas no âmbito de um quadro de regras acordadas que, direta ou indiretamente, contribuem para alcançar metas.

A diversão como resultado é ponto importante para Assis (2007) - que ressalta como fundamental que a experiência de jogar seja divertida - e para Feil \& Scattergood (2005) - que entendem o gameplay como um "conjunto de elementos que torna um jogo divertido".

Comparando-se às definições de gameplay e jogabilidade, notamos como semelhante a menção à forma como o jogador interage com a mecânica do jogo. No entanto, a definição de jogabilidade não leva em consideração o envolvimento (e a diversão) do jogador. Assim, não podemos considerar os termos equivalentes, visto a importância que o envolvimento do jogador tem nas diversas definições de gameplay encontradas.

Assis (2007) também considera imprópria a tradução do termo gameplay por jogabilidade, uma vez que "todo jogo é jogável e o que interessa é que seja interessante”. Além disso, observa que “'jogabilidade’ admite graus: alta ou baixa, o que não combina com um conceito abstrato". 
Como Assis, Bruni também não concorda com a tradução da palavra gameplay para jogabilidade e considera que seria um reducionismo do potencial conceitual que 0 termo vem assumindo hoje nos estudos videolúdicos, uma vez que restringe 0 conceito somente à noção de ludus. Para ele, o termo gameplay contém a fusão de dois sentidos importantes:

a noção de jogo (game) como um sistema organizado de regras, próximo a noção de ludus defendida por Frasca [1997]; e a noção de brincadeira (play) algo que denota tanto a noção de faz de conta (ou fábula no sentido narrativo) como o conceito de paidia. E, como afirma Frasca o sentido de ludus não é algo antagônico a paidia, e sim um subgrupo dessa ${ }^{104}$.

Então, assumimos que o gameplay emerge das interações do jogador com uma determinada construção lúdica, a partir de seu envolvimento com as regras e da manipulação de suas mecânicas, por meio da criação de estratégias e táticas que constroem a experiência de jogar.

Vale também ressaltar que o gameplay pode ser observado em jogos dos mais diversos suportes (embora seja predominantemente atribuído aos videogames) e independentemente de o jogo ter um objetivo específico a ser alcançado, ou ser um passatempo ou um jogo cujo objetivo esteja definido apenas pelas intenções do jogador.

${ }^{104}$ Opinião registrada em comentários postados no blog Realidade Sintética, referentes ao artigo "Como se analisa um videogame?", de 15 de julho de 2009, disponível em «ttp:// realidadesintetica. com/ ? $\mathrm{p}=656>$. Acessado em: 31 ago. 2009. 
Sweetser (2008:55-64) aponta que a história do gameplay tem apresentado uma tendência de maior interação e de um gameplay centrado no jogador. Ela afirma que os jogos são cada vez mais realistas e envolventes, que os jogadores estão tendo cada vez mais liberdade, com os mundos do jogo tornando-se mais intuitivos, abertos e emergentes. A autora divide a história do gameplay em uma linha do tempo relativa à interação e assim distingue quatro grandes eras, com uma progressão entre as eras, em direção a uma maior interação.

- Ficção interativa - nesta fase os jogadores são muito mais receptores do que agentes ativos no mundo do jogo. Sua ação se resume a descobrir uma história por meio de um conjunto limitado de interações tais como a digitação de palavras-chave, escolhendo uma opção em uma lista ou clicando sobre um elemento da interface. A autora cita os jogos de aventura como exemplos desta fase, como os da série Myst (Cyan Worlds, 1993), Monkey Island (LucasArts, 1993) e Indiana Jones e a Última Cruzada (LucasArts, 1989).

- J ogabilidade linear - os jogadores têm a liberdade de se mover e explorar 0 mundo do jogo, no entanto, sua interação com esse mundo ainda é bastante limitada, pois para resolver cada quebra-cabeça um conjunto ordenado de ações deve ser executado. Envolve uma história subjacente a ser descoberta, com quebra-cabeças a serem resolvidos ao longo do caminho, e um limitado e pré-determinado conjunto de formas de interação no mundo do jogo. Os exemplos citados pela autora, para esta fase, são os em estilo plataforma como Sonic (Sega, 1991) e Super Mario Bros.( Nintendo, 1985), jogos de ação 
e aventura como Tomb Raider e The Legend of Zelda, bem como RPGs como as séries Might \& Magic (New World Computing, 1987), além de alguns jogos de tiro em primeira pessoa como Half-Life (Valve Software, 1998) e Doom (id Software, 1993) que, como frequentemente envolvem algum tipo de narrativa, são essencialmente lineares.

- Jogos de construção (sandbox games) - são lugares para a experiência dos jogadores. São quase simulações, exceto pelas definições um pouco frouxa de tarefas, desafios e conclusão. Aos jogadores são dados os elementos básicos e um conjunto de regras para que criem seu próprio jogo. Por sua falta de narrativa, de objetivos claros e desafios, são muitas vezes referidos como "brinquedos", ao invés de jogos. Incluem-se como exemplos deste tipo de jogos os de construção de cidades como a série Sim City, simuladores de vida como The Sims e outros tipos de jogos de simulação como Flight Simulator X (Microsoft, 2006).

- Gameplay emergente - Ocorre quando as interações entre os objetos no mundo do jogo ou as ações do jogador resultam em uma segunda ordem de consequências, que não foi planejada pelos desenvolvedores do jogo, mas se apresentam de uma maneira racional e aceitável. É possível em função da definição de regras simples e globais e de uma definição geral dos comportamentos e das propriedades de objetos do jogo. Permite que 0 mundo do jogo seja mais interativo e reativo, criando uma ampla gama de possibilidades de ação, estratégias e gameplay. 
A autora divide o gameplay emergente em dois tipos, gameplay emergente local, que ocorre quando uma seção de jogo permite que um novo comportamento que, no entanto, não tem efeitos em cadeia para o resto do jogo, e gameplay emergente global, que surge quando as regras simples de baixo nível e as propriedades dos objetos do jogo interagem para criar um novo nível de jogo, que o altera como um todo.

Em The Sims e Half-Life 2, podemos encontrar exemplos de gameplay emergente local, a inteligência é incorporada em seus objetos, que trazem em sua programação elementos que determinam como eles podem ser afetados pelos jogadores ou outros objetos.

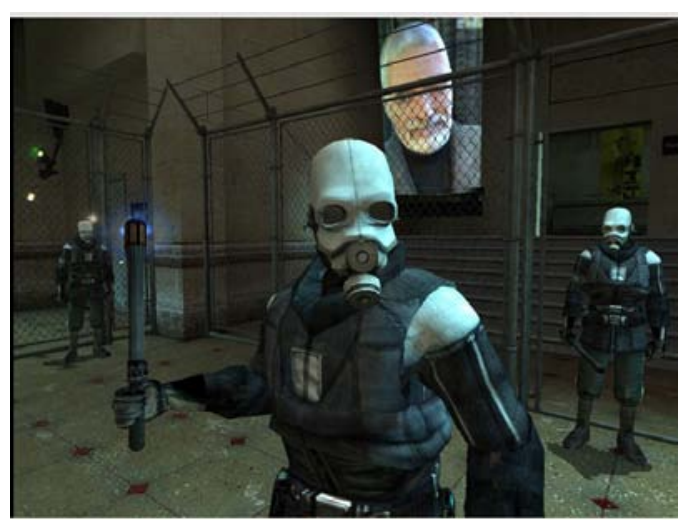

Figura 14. Half-Life 2

Gameplay emergente global pode ser encontrado em games como The Elder Scrolls IV: Oblivion (Bethesda Softworks, 2006) e Vampire: The Masquerade Bloodlines (Troika Games, 2004). Em Oblivion, há muitos personagens independentes, organizações e missões, cada uma com diferentes motivações, funções e possíveis interações com o jogador. Embora seja improvável que duas experiências de jogo sejam exatamente iguais, o jogo ainda depende de uma história central muito linear, que os jogadores devem seguir para completá-lo e as escolhas e ações do jogador tem pouco impacto sobre o resultado final. Já em Vampire, as ações e 
decisões que o jogador toma ao longo do jogo impactam na forma como o jogo e sua história terminam, o que possibilita aos jogadores um sentido muito maior de agência, uma vez que Ihes possibilita perceber que suas ações efetivamente interferem no mundo, co-criando a história.

Sweetser (2008:63) considera ainda que o gameplay emergente tem maior potencial para aumentar a apreciação do jogador em termos de intuição, consistência e liberdade de expressão, porque o coloca no centro do palco, dando-Ihe liberdade para experimentar, maior controle e senso de agência, e um menor sentimento de estar apenas descobrindo um caminho pré-definido pelos designers.

De acordo com Sweetser (2008:6) a chave para a criação de um gameplay emergente é a definição de um conj unto simples e geral de elementos e regras, que podem dar origem a uma grande variedade de comportamentos e interações interessantes e desafiadoras, em diferentes situações.

A solução mais simples que dá o resultado desejado é sempre o melhor. Tal como acontece com qualquer sistema emergente, o conjunto de regras fundamentais e os elementos permanecem constantes, mas sua situação muda de configuração ao longo do tempo. A sensibilidade dos elementos a situações de mudança e a interação dos elementos entre si e com os jogadores são o que criam a jogabilidade emergente ${ }^{105}$.

\footnotetext{
${ }^{105}$ Tradução nossa. Do original em inglês: "The simplest solution that gives the desired results is always the best. As with any emergent system, the fundamental set of rules and elements stay constant, but their situation and configuration change over time. The sensitivity of the elements to changing situations and the interaction of the elements with each other and the players are what create emergent gameplay". Sweetser (2008:6)
} 


\subsubsection{Elementos do gameplay}

Entendemos que o gameplay é, em parte, definido pelas regras e pela mecânica do jogo (quando colocadas em andamento pela ação do jogador) e engloba outros elementos como jogabilidade e os elementos que compõem a narrativa e a interface.

No entanto, além dos elementos que fazem parte do gameplay, é importante observar que existem outros que nele interferem. Assim podemos estabelecer uma divisão entre os elementos que fazem parte do gameplay, como a atitude lúdica, a jogabilidade, a narrativa e a interface, e aqueles que interferem no gameplay: imersão, agência e emergência.

\section{- Elementos que fazem parte do gameplay}

Os elementos que fazem parte do gameplay são aqueles necessários para sua instauração e, não deixam de estar, em certa medida, relacionados aos elementos constituintes do jogo.

A jogabilidade, por sua definição, relaciona-se com a interação do jogador com as regras e o ambiente do jogo; a atitude lúdica tem forte relação com o fato do jogo ser voluntário; e os elementos que compõem a narrativa e a interface não deixam influenciar e sofrer influência dos objetivos, das regras e da mecânica do jogo, uma vez que seus desenvolvimentos são interdependentes. 


\section{J ogabilidade}

O conceito de jogabilidade já foi, em parte, discutido quando os conceitos de gameplay foram apresentados.

Genvo (2009:134-139) fala sobre jogabilidade no sentido de um jogo que tem características que o tornam possível de ser jogado, o que implica em uma "estrutura jogável", composta de um conjunto de elementos que orientados por uma regra dão sentido às ações do jogador. Este entendimento de jogabilidade implica em graus. Para Genvo, esta estrutura que permite ações apropriadas para a atividade de jogar, tem uma certa "quantidade de 'jogabilidade'" 106. E para Assis (2007:19), é exatamente esta implicação em graus que torna o termo jogabilidade não apropriado enquanto tradução da palavra gameplay, conforme já foi discutido anteriormente. Cabe notar também que Genvo faz esta distinção utilizando o termo playability para jogabilidade e não gameplay.

Baseando-nos nas discussões já apresentadas e na observação de Assis (2007:19) de que o termo jogabilidade admite graus, assumimos que o conceito mais apropriado para o termo seria o seu entendimento como o proposto pela primeira parte da definição da Wikipedia para o termo, como sendo "a virtude que um jogo possui para ser fácil e intuitivo de se jogar". Um conceito bastante relacionado ao que Assis chama de curva de aprendizagem, uma vez que leva em conta o tempo que 0

106 Tradução nossa. Do original em inglês: "But in order to be able to adopt this attitude, the structure upon which the actions are performed must be appropriate to the activity of play: it must contain a certain amount of 'playability'". GENVO (2009:134). 
jogador leva para se sentir confortável com os comandos e o ambiente do jogo, considerando-se que quanto menos tempo levar, ou seja, quanto mais rápida for essa adaptação, melhor avaliada será a sua jogabilidade.

Partindo deste entendimento podemos observar que a jogabilidade, no que tange a sua capacidade de um jogo ser é fácil e intuitivo de se jogar, se estabelece a partir da interação do jogador com as regras e o ambiente do jogo, uma vez que, por determinarem o modo pelo qual o jogador irá interagir, contribuirão (ou não) para a rápida adaptação do jogador com os comandos e o ambiente do jogo.

\section{Atitude lúdica}

Genvo (2009:133-136) define atitude lúdica como um processo metafórico operado pelo jogador que voluntariamente restringe suas ações apenas àquelas permitidas pelas regras e restrições que o jogo impõe. Processo metafórico porque implica em transpor as coisas do mundo para uma outra ordem, agindo "como se". Como se o jogador fosse o personagem do jogo, como se o objeto do tabuleiro fosse o objeto que este representa no ambiente do jogo. Para usar o exemplo dado pelo autor "para jogar, o jogador de xadrez age como se o tabuleiro e os peões fossem mais do que realmente são: peças de madeira ou plástico" ${ }^{107}$.

\footnotetext{
107 Tradução nossa. Do original em inglês: "in order to play the game, a chess player must act as if the board and the pawns are more than they really are: pieces of wood or plastic". (Genvo, 2009:136).
} 
Para o autor jogar é uma questão de atitude. Genvo (2009: 137-142) sugere que uma estrutura lúdica consista de um sistema de regras formuladas por alguém, mas que nem todo sistema de regras se destina a adoção de uma atitude lúdica. 0 autor diz que é necessário que este mesmo sistema seja projetado visando a uma mediação lúdica ${ }^{108}$. Assim, este sistema de regras, para ser jogável, deve partir de uma determinada configuração dos signos que sejam coerentes com esta atitude lúdica. E, no entanto, esta estrutura jogável apenas se tornará verdadeiramente lúdica se alguém se dispuser a jogá-la e, o que pode ser divertido para um não 0 será, necessariamente, para outro.

0 autor sugere que as quatro categorias formuladas por Caillois ${ }^{109}$, que frequentemente são utilizadas para analisar os componentes presentes em uma estrutura lúdica, sejam sitematicamente encontradas assim que o jogador põe em movimento um sitema de regras formalizadas. Para o autor, "dentro do quadro do

${ }^{108} \mathrm{O}$ autor entende mediação como um fenômeno que permite compreender a difusão de formas linguísticas ou simbólicas, no espaço e no tempo, de forma a produzir um significado compartilhado dentro de uma comunidade, e no caso do design de jogos, este significado compartilhado refere-se ao ato de jogar.

109 Caillois (1967:31-58) divide os jogos de acordo com suas posturas básicas, chama agôn às modalidades de jogos onde predominam a competição dentro de regras estabelecidas e em igualdade de condições entre os competidores; aos jogos onde o jogador se entrega à sorte, Caillois chama-os alea; mimicry é o nome dado aos jogos de simulação, onde a imitação, a representação de um papel prevalece; e chama ilinx aos jogos em que a busca da vertigem, a privação temporária da estabilidade dos sentidos, está presente. Caillois afirma que vários jogos podem ser classificados como pertencentes a mais de uma categoria. 
jogo formal, quando o jogador atualiza uma explícita estrutura jogável, as quatro categorias descritas por Caillois aparecem" ${ }^{110}$.

Ao jogar o indivíduo deve experimentar o possível (alea) enquanto tenta cumprir um propósito (agôn) por meio de um processo metafórico que implica que ele atue como se o momento presente fosse diferente (mimicry) através do rompimento da realidade ordinária (ilinx). 0 autor ressalta que, dentro deste ponto de vista, 0 aspecto lúdico de ilinx repousa no sentimento de estar apartado da realidade ordinária. E que a competição (agôn) se mostra presente a todo momento em que 0 jogador pretende alcançar um resultado (mesmo que ainda não seja o resultado final), e isto, por conta da incerteza intrínseca que governa cada processo de tomada de decisão dentro de um quadro lúdico.

Para Genvo (2009: 142-143), a adoção de uma atitude lúdica depende da disposição do jogador, do que o autor, adotando o esquema de análise greimasiano, chama de "querer fazer".

Este "querer fazer" é o que Lopes (2005) chama de intencionalidade lúdica, que é produzida em cada indivíduo e expressa em termos de ludicidade. Para a autora, a ludicidade pode ser entendida como um aspecto da condição humana e sua essência pode ser localizada, em maior medida, nos processos relacionais e interativos nos

110 Tradução nossa. Do original em inglês: "Within the framework of formal play, when a player actualizes an explicit playable structure, the four categories described by Caillois appear". (Genvo, 2009:138) 
quais o indivíduo investe suas ações com sentido lúdico, do que nos resultados finais destas ações.

Assim, podemos dizer que a atitude lúdica depende da disposição do jogador, de aceitar as regras do jogo, e em função delas investir voluntariamente suas ações restringindo-as apenas àquelas ali permitidas.

\section{Narrativa}

Não pretendemos aumentar a discussão a respeito de se um jogo é narrativo ou não. Discussão essa que nos meios acadêmicos já perdura por algum tempo e sobre a qual muitos autores ainda divergem.

Alguns autores defendem o entendimento de narrativa no sentido de que todo jogo conta uma história. Como exemplo, podemos buscar as palavras de Murray (2003:138-145) que demonstra que jogos e histórias não são necessariamente opostos e os apresenta como "ações rituais que nos permitem encenar simbolicamente os padrões que dão sentido às nossas vidas" ${ }^{111}$. Para a autora todo 0 jogo, eletrônico ou não, pode ser vivenciado como um drama simbólico. "Qualquer que seja o conteúdo do jogo, qualquer que seja o nosso papel dentro dele, somos

\footnotetext{
${ }^{111}$ Huizinga também discute as funções culturais do jogo. Sobre esta sua função, o autor nos diz: "Mesmo as atividades que visam à satisfação imediata das necessidades vitais, como por exemplo a caça, tendem a assumir nas sociedades primitivas uma forma lúdica. A vida social reveste-se de formas suprabiológicas, que the conferem uma dignidade superior sob a forma de jogo, e é através deste último que a sociedade exprime sua interpretação da vida e do mundo" (Huizinga, 1938: 53).
} 
sempre os protagonistas da ação simbólica". A autora ainda coloca que nos jogos podemos encenar nossas relações básicas com o mundo ou como "textos que proporcionam interpretações de experiências". A esta última afirmação segue a apresentação de dois exemplos: de uma interpretação do capitalismo que podemos estabelecer quando jogamos Banco Imobiliário (Monopoly ${ }^{112}$ ) e uma interpretação a partir de Tetris, demonstrando como podemos criar interpretações até mesmo para jogos não verbais. Para Murray, Tetris pode ser visto como

uma encenação perfeita da vida sobrecarregada dos norte-americanos nos anos 90 - do constante bombardeio de tarefas que exigem nossa atenção e que devemos de algum modo, encaixar em nossas agendas superlotadas, não sem antes limparmos nossa mesa de trabalho a fim de abrir espaço para o próximo violento assalto (Murray, 2003: 142).

Para Murray, as histórias contadas nos videogames são elementos importantes para a imersão do jogador no ambiente do jogo.

Concordamos com a colocação de Murray, de que a narrativa seja um elemento importante para a imersão do jogador, no entanto, assim como Gomes (2008:23) entendemos que a narratividade não seja um aspecto "necessariamente importante a todos os tipos de videogames".

\footnotetext{
112 Monopoly foi criado pelo americano Charles Darrow, em 1932 e lançado em 1935 pela Parker Brothers, que comprou os direitos do jogo. No Brasil foi lançado pela Estrela com o nome de Banco Imobiliário em 1944.
} 
Não estamos com isso dizendo que a narrativa não tenha importância nos games, e sim, que essa importância varia em grau, de acordo com o tipo de jogo, podendo ter pouca ou nenhuma importância em jogos como Tetris e ser fundamental em outros jogos como o próprio Grim Fandango (LucasArts, 1998), citado por Rollings \& Adams (2003:10), ou o Cozinheiro das Almas (objeto de nossa análise no capítulo 4).
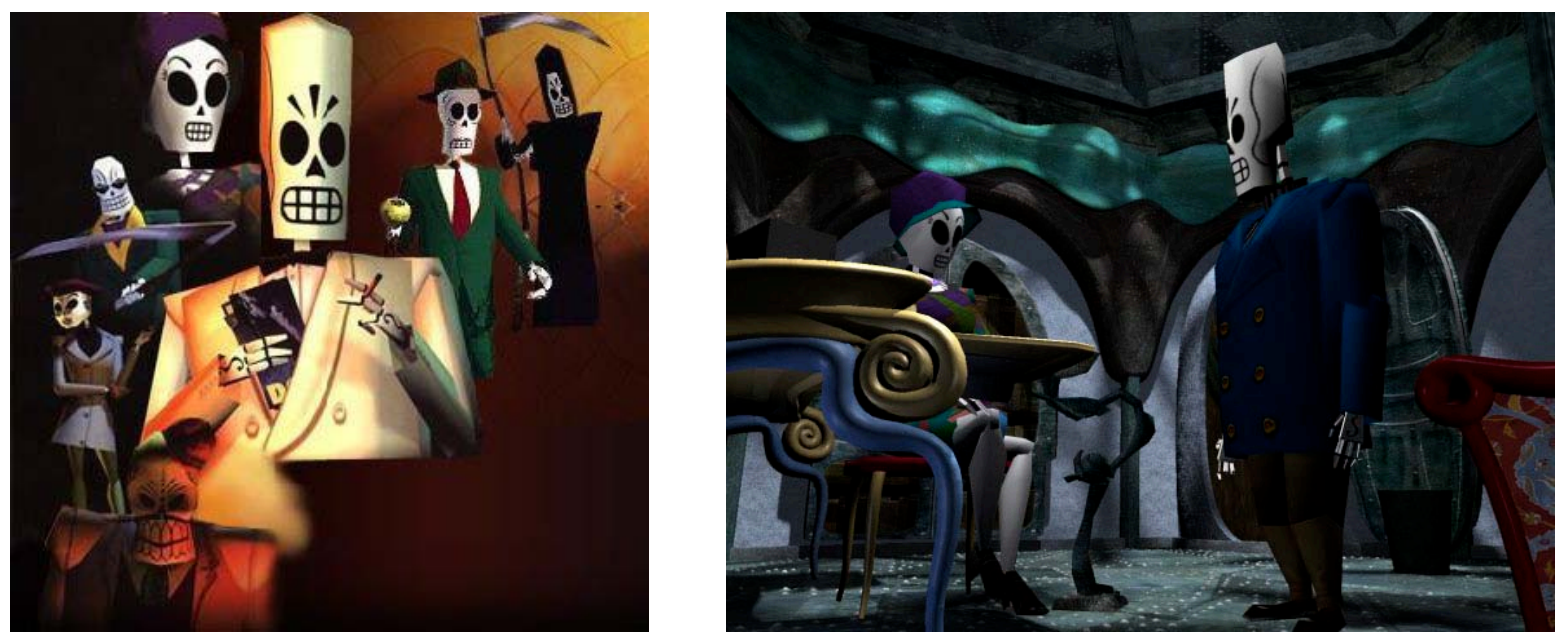

Figura 15. Grim Fandango se inspira nas festas dos mortos do folclore mexicano com um toque dos filmes noir das décadas de 30 e 40. 0 personagem principal é Manny Calavera, um esqueleto que trabalha como agente de viagem da morte e leva o jogador a explorar o Mundo dos Mortos.

Para Rollings \& Adams (2003:10),

todo o jogo conta uma história. A complexidade e a profundidade da história que depende do jogo. Num extremo, em jogos de aventura como Grim Fandango, o jogo é a história. No outro extremo, é o jogador que conta a história com o ato de jogar. Mesmo Tetris tem uma história - uma história criada pela forma como o jogador joga ${ }^{113}$.

\footnotetext{
${ }^{113}$ Tradução nossa. Do original em inglês: "All games tell a story. The complexity and depth of that story depends on the game. At one extreme, in adventure games such as Grim Fandango, the game is the story. At the other extreme, it's the player who tells the story by the act of playing. Even Tetris has a story-a story created by the player as she plays." (Rollings \& Adams, 2003:10)
} 
Para os autores, a narrativa (narrative) é a parte não interativa do jogo, a apresentação de parte da história. "Como jogar é um processo ativo e ouvir uma narrativa é um processo passivo, existe uma tensão intrínseca entre interatividade e narrativa". No entanto, para os autores, um jogo que não tenha uma história implícita não desperta o interesse do jogador ${ }^{114}$.

Fullerton (2008:86) também defende a utilização de elementos dramáticos como uma das formas de envolver o jogador.

Elementos dramáticos contextualizam o gameplay, sobrepondo e integrando os elementos formais do sistema em uma experiência significativa. Elementos dramáticos básicos, como desafios e atuação, são encontrados em todos os jogos. Técnicas dramáticas mais complexas, como premissa, personagem e história, são usadas em muitos jogos para explicar e aprimorar os elementos mais abstratos do sistema formal, criando um senso mais profundo de conexão para os jogadores e enriquecendo suas experiências como um todo ${ }^{115}$.

\footnotetext{
114 Tradução nossa. Do original em inglês: "Narrative is the noninteractive, presentational part of the story. Tetris has a story, but it contains no narrative. Because playing games is an active process and listening to a narrative is a passive one, there is an inherent tension between interactivity and narrative. (...) Without a story, or some way for a player to implicitly form his own story, the game simply will not interest the player." (Rollings \& Adams, 2003:10)

115 Tradução nossa. Do original em inglês: “Dramatic elements give context to gameplay, overlaying and integrating the formal elements of the system into a meaningful experience. Basic dramatic elements, like challenge and play, are found in all games. More complicated dramatic techniques, like premise, character, and story, are used in many games to explain and enhance the more abstract elements of the formal system, creating a deeper sense of connection for the players and enriching their overall experiences." (Fullerton, 2008:86)
} 
Ainda de acordo com Fullerton (2008:93-96), a premissa fornece um contexto para os elementos formais e torna mais fácil para os jogadores a contextualização de suas escolhas, além de envolver emocionalmente os jogadores em suas interações com os elementos que compõem o jogo. A premissa difere da história por suas qualidades narrativas. Uma premissa não parte de lugar algum, enquanto as histórias se desdobram com o jogo.

Tanto para Fullerton (2008:104-106) quanto para Bates (2004: 96-98) é importante 0 conceito de estrutura em três atos (ou arco dramático), baseado nos conceitos de Aristóteles: introdução - desenvolvimento/clímax - solução. Na introdução, a história que permeia o jogo é apresentada ao jogador, assim como, em geral, o objetivo principal do jogo. O desenvolvimento e o clímax correspondem ao desenrolar do jogo, e é permeado pelos desafios propostos ao jogador como objetivos imediatos e de médio prazo. A solução consiste na finalização do jogo, com a consequente resolução do problema e conquista do obj etivo proposto.

Na estrutura da narrativa nos jogos, diferentemente da narrativa dos meios tradicionais, onde o controle está todo nas mãos do autor, cabendo à audiência apenas seguir a história, há, de acordo com Bates (2004:101-102), um conflito direto entre a liberdade que é dada ao jogador e a linearidade necessária para uma 
história bem construída. Para o autor, "a solução é criar áreas em que o jogador tem liberdade e encadear essas áreas em uma série linear" ${ }^{116}$.

Já Sweetser (2008:11-12) vê a narrativa presente nos jogos dividida em três diferentes categorias, partindo da perspectiva do jogador. A primeira categoria vê o jogador pelo modelo tradicional de "jogador como receptor", que é o modelo elaborado a partir da contação de histórias, como nos livros ou filmes. Aqui, a história é pré-gravada e simplesmente transmitida ao jogador que não pode afetar 0 resultado ou a progressão desta. As sequências não-interativas apresentadas ao jogador entre cada fase do jogo são exemplos dessa categoria, como em Warcraft III (Blizzard Entertainment, 2002). Muitas vezes, estas sequências não-lineares funcionam mais como uma recompensa ou a motivação para a ação.

A segunda categoria é similar a primeira e trata o "jogador como descobridor". A história está inserida no mundo do jogo e cabe ao jogador descobrir o enredo pré-existente. Neste tipo de jogo cabe ao jogador descobrir algumas peças-chave para seguir em frente, como em Might \& Magic onde o jogador precisa encontrar determinados personagens para adquirir a informação que Ihe permitirá seguir em frente.

\footnotetext{
${ }^{116}$ Tradução nossa. Do original em inglês: “In games, there's a direct conflict between the freedom we must allow the player and the linearity necessary to any well-constructed story. The solution is to create areas in which the player has freedom, and then to string these areas together in a linear series." (Bates, 2004:101-102)
} 
A terceira forma é bastante diferente, é a do "jogador como criador" e implica jogadores ativamente criando e afetando a história como um produto de suas ações e interações. 0 jogador como um criador da narrativa é uma forma de emergência. A narrativa e o roteiro não são pré-determinados, emergem das interações entre as entidades (incluindo aqui o jogador) no mundo do jogo. A construção da narrativa, neste tipo de jogo, é dependente das ações do jogador. Os jogos de simulação como The Sims e Sim City se encaixam nesta categoria. Mas também podemos encontrar jogos de estratégia como Civilization (Microprose/Firaxis Games, 1991) e outros jogos abertos como os jogos de construção (sandbox games).

Gomes (2008:28) aponta para o mesmo caminho. Diz que

o conceito de narrativa parece estar se distanciando da construção prévia e otimizada de uma cadeia de causa e efeito a ser percorrida cognitiva ou "fisicamente" pelo espectador/interator. Agora, a narrativa começa a ganhar contornos de um processo de modelização de universos conceituais, de maneira sistêmica, a serem habitados pelo interator da maneira que só ele pode estabelecer a cada experiência.

Assis (2007:39-44), que começa sua discussão sobre narrativa com uma distinção entre história e narração ${ }^{117}$, diz que é importante pensar a forma como a história por trás do jogo será contada, pois sempre que há uma interrupção no jogo para 0 desenrolar da história, há uma perda de imersão. Para o autor é necessário que

117 “Para clareza, diremos que uma história é 'o que acontece', enquanto narração é 'a sequência de eventos que exibe o que acontece'". (Assis, 2007:39) 
narração, interatividade e imersão sejam bem equilibradas para garantir o sucesso do videogame:

1. Se houver personagens (NPC) que contam (narram) aos jogadores/ fruidores parte da história, estes perdem em imersão.

2. Se o jogador (e seu avatar) puder experimentar livremente (uma interatividade muito ampla), perde a imersão. Um exemplo comum dessa perda de imersão é a tática de "morrer e voltar" usada pelos jogadores para testar situações difícieis em um videogame. (...) 0 excesso de liberdade de interação também leva ao risco de o jogador perder a narração de partes da história.

3. Se o jogador não puder experimentar o mundo virtual por meio de seu avatar, o ambiente não será verdadeiramente interativo, isto é, deixará muito claras suas limitações, o que militará contra a imersão, embora seja tática que ajude a contar mais linearmente uma história.

Assim podemos observar que uma maior imersão está também relacionada aos games que possibilitam ao jogador uma agência mais efetiva, mesmo que isso implique uma narração menos determinista. Assis (2007:41-42) cita que em Half-Life 2 as informações são passadas ao jogador no contexto do jogo. Isto dilui narração, mas aumenta a imersão.

Juul (2005:156-159) apresenta uma discussão a respeito do entendimento de narrativa, propondo a observação e comparação de seis definições de narrativas (vej a Tabela 8). 


\begin{tabular}{|c|c|c|}
\hline & $\begin{array}{l}\text { Novelas/filmes/ } \\
\text { narrativas em geral }\end{array}$ & Videogames \\
\hline $\begin{array}{l}\text { 1. Narrativa como } \\
\text { apresentação de eventos } \\
\text { (narrativa/ narração) }\end{array}$ & Sim & $\begin{array}{l}\text { Não: Jogos como atividades e regras - } \\
\text { jogos não apenas representam eventos, } \\
\text { eles são eventos. } \\
\text { Sim: J ogos como mundos ficcionais. }\end{array}$ \\
\hline $\begin{array}{l}\text { 2. Narrativa como uma } \\
\text { sequência de eventos fixa e } \\
\text { pré-determinada (história) }\end{array}$ & Sim & $\begin{array}{l}\text { Geral: não. } \\
\text { Sim: Em jogos de progressão com } \\
\text { sequências pré-determinadas que os } \\
\text { jogadores têm que desempenhar para } \\
\text { completar o jogo mas não como todas } \\
\text { as tentativas falhas do jogador. }\end{array}$ \\
\hline $\begin{array}{l}\text { 3. Narrativa como um tipo } \\
\text { específico de sequência de } \\
\text { eventos (história) }\end{array}$ & Sim & $\begin{array}{l}\text { Geral: não. } \\
\text { Sim: jogos de progressão podem conter } \\
\text { isto. }\end{array}$ \\
\hline $\begin{array}{l}\text { 4. Narrativa como um tipo } \\
\text { específico de tema (atores } \\
\text { humanos ou antropomórficos) }\end{array}$ & Sim & $\begin{array}{l}\text { Depende do mundo ficcional de um } \\
\text { jogo. }\end{array}$ \\
\hline $\begin{array}{l}\text { 5. Narrativa como qualquer } \\
\text { tipo de configuração geral ou } \\
\text { mundo ficcional. }\end{array}$ & Sim & $\begin{array}{l}\text { Não: jogos como atividades e regras. } \\
\text { Sim: jogos como mundos ficcionais, com } \\
\text { a ressalva de que os jogos, de forma } \\
\text { exclusiva, tendem a apresentar mundos } \\
\text { incoerentes. }\end{array}$ \\
\hline $\begin{array}{l}\text { 6. Narrativa como a nossa } \\
\text { forma de dar sentido ao } \\
\text { mundo. }\end{array}$ & $\begin{array}{l}\text { Sim, como tudo no } \\
\text { mundo. }\end{array}$ & Sim, como tudo no mundo. \\
\hline
\end{tabular}

Tabela 8. Videogames e seis definições de narrativa (traduzida de J uul, 2005:158) 
De acordo com o autor, só podemos considerar que todo jogo apresenta uma narrativa, se considerarmos a narrativa como uma forma de dar sentido ao mundo. Qualquer outra forma de entendimento, ao ser aplicado aos videogames deve ser feita com ressalvas. Se considerarmos os jogos como atividades e regras, os diversos conceitos de narrativa não se aplicam aos videogames (e J uul destaca este fato nas análises das definições 1 e 5 de sua tabela). No entanto, se considerarmos jogos como mundos ficcionais, todas as mesmas demais definições ( 1 a 5, da tabela de Juul) se aplicam aos jogos.

Assim, podemos afirmar que a importância da narrativa variará conforme um jogo apresente ou não um mundo ficcional e de acordo com a importância desse mundo ficcional para o entendimento do jogo e imersão do jogador dentro do ambiente desenhado por este, como base para o desenvolvimento do jogo.

Como elemento que faz parte do gameplay, consideramos que, quando presente, a ideia de narrativa deva englobar em si os personagens, o enredo, e caminhos/ possibilidades interativos dele decorrentes.

\section{Interface}

Por interface estamos nos referindo a toda superfície de contato do jogador com 0 ambiente do jogo, não nos restingindo à tela e às formas de controle, mas sim, incluindo aqui a representação gráfica e sonora como um todo, uma vez que consideramos que estes elementos sobre os quais o jogador age e que a ele reagem 
são importantes no estabelecimento do contato com o jogo e podem contribuir para a imersão e envolvimento do jogador, ao mesmo tempo em que podem ter grande importância na orientação deste no desenvolvimento do jogo.

Não queremos com isso, no entanto, dizer que os dispositivos de controle não tenham importância, crucial, inclusive, no engajamento e imersão do jogador. Reconhecemos que estes dispositivos e sua facilidade ou não de uso interferem no desempenho e envolvimento do jogador.

A nossa proposta, no entanto, no sentido de ampliar o conceito de interface, deve-se, em parte, a uma tendência observada em estudos recentes, que busca, com esta dilatação do conceito, melhor aplicá-lo a qualquer tipo de jogo.

Nieuwdorp (2005:2-9) defende que "o status da interface como um intermediário entre o usuário e o sistema (tecnológico) com que ele/ ela interage torna o foco mais importante para determinar a fronteira que é atravessada da realidade ao jogo" ${ }^{118}$. O trabalho da autora foca, principalmente a definição de interfaces em jogos pervasivos e discute que, aplicada aos jogos digitais, a interface é invariavelmente igualada a qualquer hardware (controladores ou similares, por exemplo) ou o software (ou seja, elementos visuais do mundo do jogo) que dá origem à interação homem/ computador. Nieuwdorp observa que a tela costuma ser

\footnotetext{
${ }^{118}$ Tradução nossa. Do original em inglês: "I argue that the status of the interface as an intermediary between the user and the (technological) system he/ she interacts with makes it the most important focus to determine the border that is crossed from reality to game". (Nieuwdorp, 2005:2)
} 
vista como o melhor exemplo de interface e afirma que quando aplicado a jogos digitais, é principalmente determinada como uma tela fixa e os dispositivos de jogo (controladores como mouses e joysticks, por exemplo) e é "cada vez mais vista como um potencial obstáculo às qualidades da experiência imersiva de jogos" ${ }^{119}$. É neste ponto de seu artigo que a autora questiona se este entendimento de interface abrange satisfatoriamente a todos os tipos de jogos. Para ela, para atender principalmente as especificidades do jogo pervasivo, que mistura a realidade da rua à realidade do jogo, é necessário se ultrapassar esses limites do entendimento da interface pelo que ela chama de interface liminar, que é "a interface localizada na mente do leitor [...], e se refere à alternância semiótica entre o domínio do mundo da vida e o domínio semiótico do jogo pervasivo" ${ }^{120}$.

A autora ainda divide esta interface em dois níveis diferentes: o da interface paratélica e o da paralúdica. 0 conceito de interface paratélica refere-se a um estado da mente em que uma pessoa torna-se brincalhona e, ao tomar a decisão de jogar e entrar em qualquer mundo de jogo, deixa pra trás as convenções e práticas que estão presentes no domínio do mundo da vida cotidiana. Mas para engajar-se realmente ao jogo é necessário que o jogador ultrapasse o limite paratélico e adote

\footnotetext{
119 Tradução nossa. Do original em inglês: “When applied to digital games, the interface is determined as a fixed screen and gaming device [18], and is increasingly seen as a potential obstacle to immersive qualities of the gaming experience [3]". (Nieuwdorp, 2005:3)

120 Tradução nossa. Do original em inglês: "The liminal interface, then, is the interface located in the mind of the player we discussed before, and refers to the semiotic switch between the lifeworld domain and the semiotic domain of the pervasive game. This interface can be divided into two different levels: the paratelic and the paraludic interface". (Nieuwdorp, 2005:8)
} 
uma postura condizente com o que a autora define como sendo a interface paralúdica.

Uma vez que o jogador ultrapassou o limite para o estado paratélico, ele / ela deve aprender a compreender as regras do jogo. Tomando essas convenções semióticas, em que o significado é atribuído de forma específica para o mundo do jogo, significa aceitar esse mundo de jogo e ser capaz de funcionar dentro dele como um jogador alfabetizado ${ }^{121}$.

Bayliss (2007:96-98) entende interface como "um determinado lugar ou espaço onde a interação entre o jogador e o jogo resulta numa experiência particular que chamamos de gameplay" ${ }^{122}$. 0 autor utiliza o termo interface de forma mais ampla do que no seu sentido usual como uma propriedade do sistema de jogo, que se restringe aos controladores, telas ou menus, estendendo seu entendimento para além das características formais, considerando "os diferentes usos potenciais que um videogame, através da interface, apresenta para o jogador" ${ }^{123}$.

${ }^{121}$ Tradução nossa. Do original em inglês: "Once the player has crossed the threshold into the paratelic state, he/she must learn to understand the rules of the game. Taking on these semiotic conventions, in which meaning is assigned in ways specific to the game world, means accepting this game world and being able to function within it as a literate player". (Nieuwdorp, 2005:9)

122 Tradução nossa. Do original em inglês: "A sense of the term will be developed that understands the interface as a particular site or space where the interaction between the player and the game results in the particular experience we call gameplay." (Bayliss, 2007:96)

${ }^{123}$ Tradução nossa. Do original em inglês: “It must be emphasised that 'interface' is used here more broadly then in its usual sense as a property of the game-system, such as the controllers, television screens, or on screen menus. (...) Rather the 'interface' is used here to describe the sites or spaces of interaction between the player and the game, extending beyond the formal characteristics towards a consideration of the different potential uses that a videogame, via the interface, presents to the player." (Bayliss, 2007:98) 
Já para Järvinen (2003: 77) a interface, nos videogames, é o ponto de referência de atenção dos jogadores na camada física do jogo, o que a torna constantemente presente enquanto parte da experiência do jogador. 0 autor considera ainda que a interface acumula funções de portal e porteiro para os jogos digitais, o que significa que sendo a interface a única maneira de aprovar os procedimentos realizados pelo jogador, acaba por enfatizar em todos os jogos digitais, e em algum grau, a mecânica do jogo. 0 autor nos lembra ainda que aprender a jogar um jogo digital qualquer pressupõe aprender a utilizar sua interface, o que significa que esta torna-se parte das regras do jogo.

\section{- Elementos que interferem no gameplay}

Se o gameplay é o conjunto de elementos responsáveis por fornecer ao jogador uma experiência significante e divertida, imersão, agência e emergência são conceitos que devem ser levados em conta, uma vez que contribuem para o envolvimento do jogador.

\section{Agência}

Por agência, entendemos o que Murray (2003:127) define como "a capacidade gratificante de realizar ações significativas e ver os resultados de nossas decisões e escolhas". A autora entende a interatividade dos ambientes eletrônicos em termos de 'agência'. No entanto, alerta que em função do uso vago e difundido do termo interatividade, muitas vezes, o prazer da agência é confundido com o simples clicar com o mouse ou 0 ato de movimentar o joystick. Para ela, "a agência vai além da 
participação e da atividade" e depende do grau de autonomia que estão presentes nas escolhas do jogador, em função da gama de escolhas possíveis, definidas pelas regras do jogo.

Machado (2002) traduz o termo agency por agenciamento, e em termos de significados dicionarizados ambos, agência e agenciamento, se equivalem. Para o autor, agenciar é "experimentar um evento como o seu agente, como aquele que age dentro do evento e como o elemento em função do qual o próprio evento acontece".

Murray exclui o acaso como gerador de agência ${ }^{124}$. Agência estaria, então, mais fortemente ligada ao conceito de agôn, de Caillois, excluindo a alea. Desta forma, embora as ações em um jogo de azar (alea) exijam do jogador uma ação, pelo fato dos resultados não serem previsíveis, já que estão sob o domínio do acaso, esta não seria uma ação no sentido de agência, já que os resultados não dependem, efetivamente, de nossas decisões e escolhas, embora, de alguma forma, estejam ligados a elas.

\footnotetext{
${ }^{124}$ Mas atividade por si só não é agência. Por exemplo, num tabuleiro de jogo de azar, os jogadores podem manter-se muito ocupados girando a roleta, movendo peças do jogo e trocando dinheiro, mas eles não podem ter qualquer sentido real de agência. As ações dos jogadores geram efeitos, mas tais ações não são escolhidas por eles e seus efeitos não estão relacionados às intenções dos jogadores. (Murray, 2003:128).
} 
No entanto, o jogador não pode fazer o que quiser, suas ações são restritas às possibilidades do jogo, ou, como diz Machado (2002) ao "que a máquina prevê como possibilidade de ocorrência (a menos que estejamos diante de um programa aberto e o interator seja capaz de intervir no próprio âmbito da programação)".

Embora este agenciamento, nos videogames, esteja restrito à programação e às regras do jogo e o computador possa ignorar as entradas inadequadas, o jogador, ao experimentar o ambiente para descobrir os limites estabelecidos, muitas vezes tem uma sensação que podemos relacionar ao chamado efeito de liberdade.

O efeito de liberdade dá ao jogador a sensação de "estar no controle" do jogo, no entanto, todas as suas respostas estão entre as programadas pelo autor, fazem parte da matriz virtual do game. O uso deste efeito de liberdade é um dos responsáveis pelo sucesso de vários games, garantindo o que se entende como imersão do jogador no ambiente do jogo.

Muitas vezes, quando os jogadores têm a sensação de estar no controle do jogo e esta sensação é rompida, rompe-se também a sensação de imersão que o jogo proporciona. Por exemplo, em Half-Life 2 existem algumas portas pelas quais não podemos seguir, elas não podem ser abertas e nem mesmo arrombadas, ao contrário de muitas outras disponíveis no jogo. 


\section{Imersão}

Imersão é a sensação que o jogador experimenta de se sentir envolvido com o jogo. Para Assis (2007:31-34) imersão "em videogames, indica uma qualidade de experiência absolutamente privada e livre de riscos, impossível de ser obtida no mundo real". O autor observa ainda que existe um dilema entre imersão e aprendizado, pois

se não houver aprendizado, então o jogador é obrigado a uma atividade de constante tatear até dar com ações eficazes. Ao fazer isso, ele perde imersão no ambiente, já que não é natural que tudo deva ser tocado/mexido para que aprendamos onde estamos. Se houver aprendizado explícito, então o jogador perde imersão, pois o programa, de tempos em tempos, dirige-se a ele e não ao avatar.

Para 0 autor, até 0 momento, a melhor saída encontrada para este dilema foi a diluição de instruções, garantindo que primeiro venha a imersão e que o jogador se identifique com o seu avatar, sentindo-se realmente dentro do ambiente, para depois, virem as instruções.

os jogos atuais fazem com que aconteça uma imersão inicial e o resultado é que, quando o NPC 225 diz ao avatar, "tente pular atrás de mim, pressione Ctrl+Espaço", o resultado é um ganho dramático. Não é exatamente ao jogador que o NPC está se endereçando, mas a seu avatar. [...] Mesmo que ela continue a fazer, como tem de ser, menção a comandos, e portanto fora do mundo, ainda assim o ganho é enorme. (Assis, 2007:33-34)

\footnotetext{
${ }^{125}$ NPC - Non Playable Character - refere-se aos personagens que fazem parte do jogo e não podem ser controlados pelo jogador.
} 
Para Sweetser (2008:48-49) imersão relaciona-se aos aspectos do jogo (como áudio, gráficos e os aspectos narrativos) que atraem o jogador para o jogo, levando-os a acreditar que este é real e suspendendo sua descrença. Para a autora, uma das formas de se saber se um jogo é imersivo ou não é por sua capacidade de produzir respostas emocionais nos jogadores (como medo ou felicidade). Sweetser considera o áudio um dos aspectos mais importantes por sua capacidade em produzir estas respostas emocionais e por fornecer um feedback imediato aos jogadores. Para Sweetser, os gráficos não precisam ser espetaculares, mas devem ser coerentes com o mundo apresentado, ou romperão a imersão criada. Ela diz que "como regra, os gráficos devem ser coerentes e não deve haver nada que chame a atenção de um jogador como sendo errado ou fora de lugar" ${ }^{126}$. Com relação aos aspectos narrativos, a importância recai sobre uma boa introdução e uma narrativa ou enredo fortes. A introdução dá aos jogadores o pano de fundo, "diz-Ihes quem são, porque estão ali, e o que estão fazendo - sua motivação para jogar. Os jogadores então se sentirão como parte da história e vão querer saber mais" ${ }^{127}$.

\footnotetext{
${ }^{126}$ Tradução nossa. Do original em inglês: "As a rule, graphics should be consistent and there should be nothing that catches a player's eye as being wrong or out of place". (Sweetser, 2008:49)

${ }^{127}$ Tradução nossa. Do original em ingles: "A game's introduction gives the players the storyline and background, tells them who they are, why they're here, and what they're doing - their motivation for playing. The players then feel like they are part of the story and they want to find out more". (Sweetser, 2008:49)
} 
Sweetser considera a imersão como um dos componentes do Fluxo de J ogo, um modelo de divertimento para jogos, baseado nos elementos de fluxo ${ }^{128}$ :

- Concentração - os jogos devem exigir concentração e o jogador deve ser capaz de se concentrar no jogo.

- Desafio - o jogo deve ser desafiante o suficiente e corresponder às habilidades do jogador.

- Habilidades dos jogadores - o jogo deve apoiar-se no desenvolvimento e superação das habilidades do jogador.

- Controle - o jogador deve sentir que tem o controle de suas ações no jogo.

- Objetivos claros - estes devem ser proporcionados aos jogadores a tempos adequados.

- Feedback - o jogador deve receber retornos apropriados a tempos igualmente apropriados.

- Imersão - estabelece que os jogadores devem experimentar, sem esforço, um profundo envolvimento com o jogo.

- Interação social - o jogo deve apoiar e criar oportunidades para a interação social.

Ainda com relação à imersão, a autora afirma que esta provoca no jogador uma menor consciência de si mesmo e de seus arredores, assim como uma menor

\footnotetext{
${ }^{128}$ Sweetser define fluxo como uma experiência tão gratificante que as pessoas estão dispostas a realizá-la pela experiência em si, com pouca preocupação com ganhos que advirão desta, mesmo quando é difícil ou perigosa.
} 
preocupação com a vida cotidiana e uma alteração em seu sentido de tempo, ao mesmo tempo em que se sente emocional e visceralmente envolvido com o jogo.

Machado (2002) considera que existem dois tipos principais de imersão: um em que podemos observar a cena de um ponto de vista externo, como em situações em que o jogador vê o seu personagem em ação - e para este caso, Machado cita como exemplo o videogame Mortal Kombat (Midway Games, 1992) - ou, de forma mais imersiva, de um ponto de vista interno, "através de um efeito de câmera subjetiva, como acontece em Doom, em que os meus opositores se dirigem a mim (isto é, à tela que estou visualizando, como seu eu estivesse realmente presente na cena)".

Para Gomes (2008:61-62) imersão e presença "são dois lados da mesma moeda". Para ela, ser o personagem, em qualquer que seja o gênero do jogo, é, "antes e acima de qualquer outra coisa, imergir no universo espacial do jogo através de seu corpo. O lado de cá da imersão, através da corporalidade do personagem, implica a noção de presença".

Ryan (2001:120-157) parte da fenomenologia da leitura, destacando um tipo específico de imersão, que pressupõe uma relação imaginativa com um mundo textual. Neste contexto imersão é a experiência através do qual um mundo ficcional adquire uma presença autônoma. A partir deste conceito a autora aponta três tipos de imersão textual, que podemos tomar de empréstimo e relacioná-los aos videogames: 
1. Espacial: o leitor desenvolve um senso de lugar, a sensação de estar no local dos acontecimentos narrados.

2. Temporal: o leitor é apanhado pelo suspense da narrativa, por um desejo ardente de saber o que acontecerá em seguida.

3. Emocional: referindo-se ao fenômeno do desenvolvimento de um apego pessoal aos personagens, de participarem em sua experiência humana.

Ao tomar de empréstimo os tipos de imersão apontados por Ryan e relacioná-los aos videogames devemos acrescentar mais um tipo a esta categorização, especialmente relacionado às sensações corporais provocadas pelos jogos. Em alguns games, em especial os de corrida, os corpos dos jogadores aderem aos movimentos de seus personagens, mesmo eles tendo consciência de que tudo aquilo na tela não acontece de verdade. Por exemplo, é usual observarmos jogadores inclinarem seus corpos nas curvas ou acompanhar os movimentos de seus carros. São reações aos estímulos visuais que chegam diretamente ao corpo, sem passar pela atenção.

Com a inclusão deste novo tipo proposto e procedendo as adaptações para os videogames, temos os quatro seguintes tipos de imersão: 
1. Espacial: o jogador compartilha o local dos acontecimentos com os personagens e/ ou demais jogadores, sente-se inserido no mundo do jogo.

2. Temporal: 0 jogador acompanha 0 tempo do evento ${ }^{129}$ e engaja-se em descobrir o que virá em seguida.

3. Emocional: refere-se ao fenômeno do desenvolvimento de um apego pessoal aos personagens, à identificação do jogador com seu avatar no jogo.

4. Sinestésica: refere-se à aderência dos corpos dos jogadores aos movimentos do seu personagem, provocando reações em seus corpos sem passar pela atenção; diz respeito às sensações corporais provocadas pelos jogos.

Um dos aspectos de apelo mais conhecidos dos jogos digitais, para Bayliss (2007:99), é sua capacidade de obter respostas afetivas do jogador, que muitas vezes é tratada em termos de imersão, no sentido de que o jogador, de alguma forma, se sente presente, parte do mundo do jogo que está jogando, e isso baseia-se, segundo o autor, na ideia de suspensão da descrença. Bayliss associa essas experiências afetivas do jogador ao conceito de ilinx de Caillois,

${ }^{129} \mathrm{O}$ tempo do evento é aqui entendido nos termos definidos por Juul, sendo o Tempo do Evento [Event time] o tempo dos eventos em um jogo, referindo-se ao tempo em que o jogo se passa e à forma como ele decorre no jogo e que é diferente do que ele chama de Tempo de jogo [Play time], que refere-se ao tempo usado pelo jogador para jogar o jogo. 
ou vertigem, categoria de jogos 'que consistem em uma tentativa de destruir momentaneamente a estabilidade da percepção e infligir uma espécie de pânico voluptuoso sobre uma outra mente lúcida'. Poderíamos acrescentar 'e ao corpo' a essa frase ${ }^{130}$.

No entanto, o autor adverte para o cuidado de não cairmos em uma conta ingênua, considerando imersão como "espacismo", e que a Teoria do Fluxo melhor se adaptaria a descrever essa experiência do jogador, e deve ser entendida como "um tipo de esforço de investimento de atenção para a atividade de jogar" ${ }^{131}$. Bayliss observa ainda que, embora essa teoria tenha em comum com os conceitos gerais de imersão o aspecto de perda da autoconsciência, um aspecto qualitativo deve ser sublinhado e trata-se do fato de que nesse conceito da experiência de fluxo, 0 sentido de si mesmo do jogador é expandido de modo que o jogador possa ter um sentimento de união ou de envolvimento com o jogo, sem perder a consciência da situação contextual em que está envolvido.

Concordamos com Bayliss no sentido de que a imersão deva ser entendida mais como uma ampliação da percepção que o jogador tem de si no sentido de se sentir envolvido com jogo mas ainda assim consciente de seu papel de jogador, uma vez

\footnotetext{
130 Tradução nossa. Do original em inglês: "This ability of digital games to elicit such affective responses from their players is a widely known aspect of their appeal, perhaps because of Caillois' ilinx, or vertigo, category of games 'which consist of an attempt to momentarily destroy the stability of perception and inflict a kind of voluptuous panic upon an otherwise lucid mind'. We might append 'and the body' to that sentence". (Bayliss, 2007:99)

${ }^{131}$ Tradução nossa. Do original em inglês: “ (...) the flow experience is instead better understood as a type of engagement, specifically an effortless type of investment of attention to the activity of playing(...)". (Bayliss, 2007:99)
} 
que o jogador tem a possibilidade de desconectar-se do jogo quando desejar. E ainda, devemos considerar que esta imersão possa ser entendida em termos de variação de graus. Indo, desde a imersão, que se verifica quando o jogador entra no círculo mágico do mundo dos jogos, até àquela em que o jogador se sente verdadeiramente o seu avatar, assumindo para si a personalidade de seu personagem.

\section{Emergência}

Emergência é definida como o surgimento de realidades complexas a partir da aplicação de regras simples.

Para Sweetser (2008:2) o conceito de emergência descreve propriedades, comportamentos e estruturas que ocorrem em altos níveis de um sistema, que não estavam presentes ou não eram previsíveis em baixos níveis. Para ela, os jogos podem apresentar potencialmente três ordens (ou níveis) de emergência: de primeira, de segunda e de terceira ordem.

- Primeira Ordem - A emergência de primeira ordem aparece nos jogos quando as interações locais provocam uma reação em cadeia, quando as ações do jogador se espalham pelo mundo do jogo, afetando não apenas o alvo da ação como também os elementos mais próximos.

- Segunda Ordem - Emergência de segunda ordem acontece quando os jogadores usam os elementos básicos do ambiente de jogo para formar suas próprias estratégias e resolver problemas de formas novas. Personagens 
também são capazes de utilizar ou combinar suas ações básicas para expor novos comportamentos ou estratégias. Este tipo de emergência ainda tem efeitos locais, e seu efeito não impacta o jogo como um todo. No entanto, eles permitem maior liberdade e criatividade ao jogador.

- Terceira Ordem - A emergência de terceira ordem ocorre em escala global. As mudanças afetam o jogo como um todo. Os limites de jogo são suficientemente flexíveis para permitir que o jogador crie caminhos novos e originais. 0 que acontece, neste nível de emergência, muda o jogo como um todo.

Sweetser (2008:64) afirma que jogos emergentes têm maior rejogabilidade, porque a cada vez, o jogador pode tomar decisões diferentes que mudarão o jogo como um todo, o que resultará em diferentes possibilidades de ação.

Encontramos ecos das palavras de Sweetser nas colocações de Juul (2005:67-83), que também vê maior rejogabilidade em jogos de emergência, justamente por possibilitarem sessões de jogos diferentes a cada vez que o jogador o joga, e cita 0 jogo Pong (Atari, 1972) como exemplo disto, quando estabelece uma comparação entre jogos de emergência e jogos de progressão.

J ogos de emergência e jogos de progressão são os nomes dados por J uul às formas como os jogos podem ser estruturados e fornecer desafios para os jogadores. 
Para J uul (2005:72-73), progressão é uma estrutura mais recente e adentrou o universo dos videogames através do gênero de aventura. Em contrapartida, define emergência como a estrutura primordial do jogo, onde é especificado um pequeno número de regras que combinam e rendem um amplo número de variações de jogo, que exigem que os jogadores concebam estratégias para manipulá-las.

Nos jogos de progressão, o jogo termina se o jogador não desempenha as ações corretas. Uma das características dos jogos de progressão é que haja mais modos de falhar do que ter sucesso. Este tipo de estrutura concede ao designer um forte controle do jogo e "uma vez que o designer controla a sequência de eventos, é também onde encontramos os jogos com ambições cinematográficas ou narrativas" 132 .

Já nos jogos de emergência existem muitas formas de se alcançar o objetivo, que por ser definido de forma ampla, permite vários estados de jogo que se qualificam como este objetivo. Estes jogos que exibem uma assimetria básica entre a relativa simplicidade das regras e a relativa complexidade de se jogar o jogo, uma vez que permite diversas combinações, que por seu turno, permite o desenvolvimento de diversos estilos de jogo.

\footnotetext{
132 Tradução nossa. Do original em inglês: "The progression structure yields strong control to the game designer: Since the designer controls the sequence of events, this is also where we find the games with cinematic or storytelling ambitions". (J uul, 2005:73)
} 
0 game Cogs (Lazy 8 Studios, 2009) tem uma mecânica conhecida e apesar de ser fácil de jogar é ainda assim desafiante tanto em função da complexidade dos desafios propostos (são 50 níveis e 3 modos de jogo), quanto pelo fato de que 0 jogo avalia o desempenho do jogador concedendo-Ihe medalhas de ouro, prata ou bronze, se o jogador completar o desafio dentro de determinados números de movimentos e tempo. 0 jogo baseia-se em deslizar as peças para os espaços vazios, a mesma mecânica do quebra-cabeça deslizante (sliding puzzle), inventado por volta de 1874, por Noyes Chapman. A simplicidade de suas regras possibilita a emergência de diversas variações do estado de jogo e também possibilita 0 desenvolvimento de diferentes estilos de jogo.
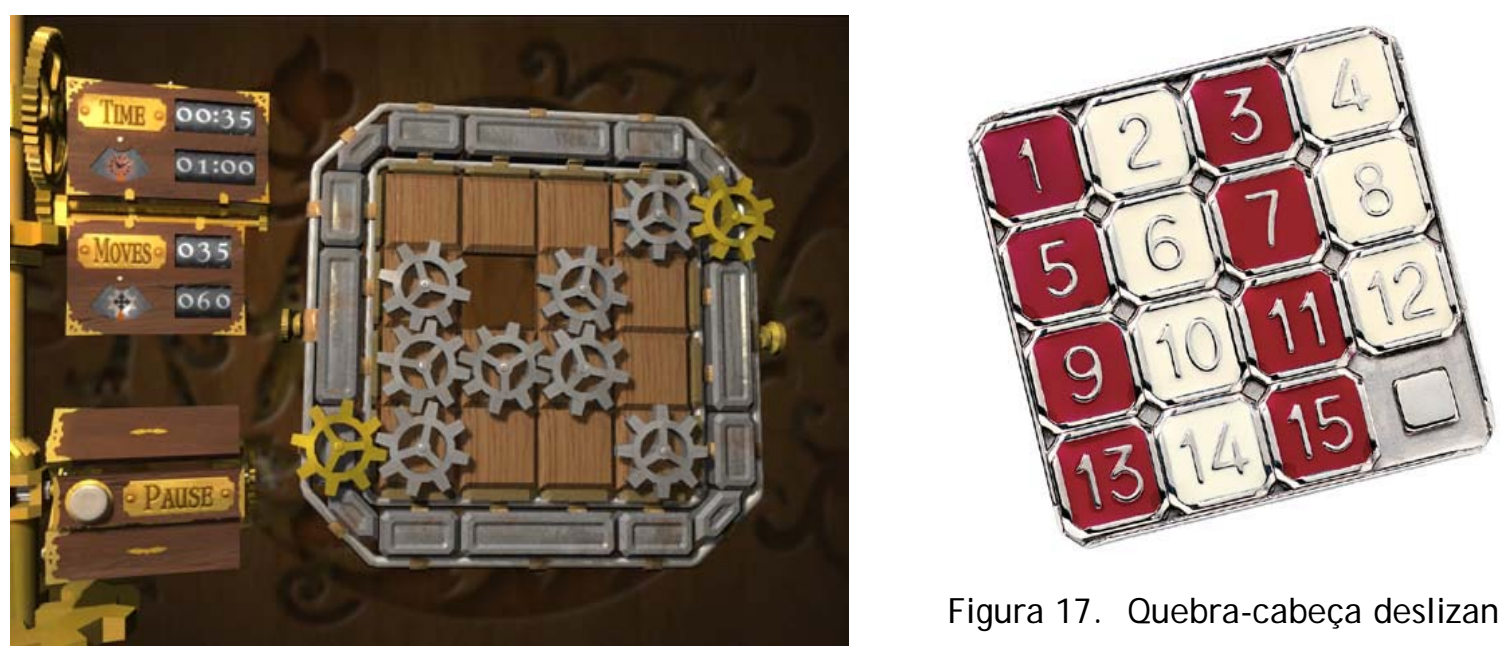

Figura 17. Quebra-cabeça deslizante

Figura 16. Cogs 
O game designer Harvey Smith ${ }^{133}$ faz uma distinção entre emergência desejável, que aparece quando a interação entre os diversos elementos do jogo leva a um gameplay interessante, e a emergência indesejável, onde os jogadores encontram meios para explorar as regras deixando o jogo menos divertido. Sweetser (2008:11) também se refere a esta dificuldade de controle dizendo que embora a incerteza possa ser desejável quando cria um gameplay interessante, pode ser indesejável quando gera ações que destroem o jogo. E alerta que quanto mais complexo 0 sistema, mais variações de comportamento o jogo é capaz de exibir e mais, e mais exaustivos testes são necessários para não permitir esses comportamentos indesejáveis.

Cuzziol (2007:44-49) enfatiza a importância dos testes, justamente porque os comportamentos emergentes, decorrentes da interação dos objetos e das regras, nem sempre resultam em algo desejável para o programador. 0 autor explica, que na programação de comportamento de personagens, o controle do programador limita-se às regras de interação entre objetos, sejam eles personagens ou outros elementos do game. 0 único modo de saber ao certo qual o impacto dessas regras no comportamento macro é rodar o programa e assistir a seus desdobramentos. Macrocomportamentos exibidos por personagens são emergentes por não serem explicitamente programados ou previsíveis, mas é importante lembrar que tais comportamentos estão solidamente codificados nas regras originais, ainda que 0 programador responsável não os possa prever.

${ }^{133}$ Apud J uul, 2005: 76. 
Notamos que J uul (2005:80-81) também demonstra essa preocupação com os testes quando ele fala do que chama de irredutibilidade que, para ele é uma das diferentes variações de emergência em jogos: emergência como variação, como padrões, como irredutibilidade e como novidade ou surpresa

1. Emergência como variação refere-se à variedade de estados possíveis e de sessões de jogo, permitidas pelas regras. Em Pong, por exemplo, a variação decorre da interação das regras simples do jogo.

2. Emergência como padrão. Diz respeito àqueles padrões que o jogador não pode deduzir imediatamente das regras do jogo, mas que aumentam 0 envolvimento do jogador. Aqui, Juul cita como exemplos os jogos de estratégia, uma vez que estes requerem algum tipo de padrão, de regularidade na execução do jogo e jogos que requerem a formação de equipes ou dão vantagens ao trabalho em grupo, como em Counter-Strike (Valve Software, 1998) ou EverQuest (Verant Interactive, 1999), respectivamente.

3. Emergência como irredutibilidade. A irredutibilidade diz respeito a necessidade de se testar um jogo, uma vez que a interação entre suas regras e seus elementos não pode ser totalmente prevista. Ilustrando isso, J uul faz uma comparação entre a forte recomendação de designers a respeito do préteste de jogos, pois muito das interações não podem ser previstas antes do jogo ser colocado em andamento. Em jogos com sitemas complexos, emergentes, o comportamento só pode ser, efetivamente, encontrado por meio de uma simulação explícita. 
4. Emergência como novidade ou surpresa. Este tipo de emergência pode ser observado quando diversas regras ou objetos são combinados de um jeito inusitado, surpreendendo o jogador ou o designer que criou o jogo. “Um jogo com muitas conexões entre diferentes objetos e regras certamente aumenta a probabilidade dos jogadores encontrarem imprevisíveis combinações de regras" $^{134}$. Juul cita como exemplo, para esse tipo de emergência, uma situação em Quake III Arena (id Software, 1999) onde o jogador se utiliza de uma tática para saltar mais longe do que seria capaz, pulando para 0 ar, enquanto dispara um foguete no chão, para então voar sobre a onda de choque da explosão.

Voltando à divisão que J uul (2005:71-72) estabelece entre jogos de progressão e jogos de emergência, vale dizer que o autor observa que nem todos os jogos podem ser enquadrados em uma ou outra categoria e que existem muitos jogos que estão numa escala entre um e outro. Assim, nessa escala, ele acrescenta às outras duas, dois modos principais de híbridos:

- Jogos de progressão pura: o exemplo mais puro inclui os tradicionais jogos de aventura.

- Jogos de emergência pura: incluem os jogos de tabuleiro, de cartas, de ação ou de estratégia como os melhores exemplos.

\footnotetext{
134 Tradução nossa. Do original em inglês: "Designing a game with many connections between different objects and rules certainly increases the likehood that players will find umpredicted rule combinations". (J uul, 2005:81)
} 
- Jogos de progressão com componentes emergentes: este híbrido pode ser observado em jogos de ação para um único jogador. 0 jogador "tem que atravessar um número de áreas onde cada uma delas pode ser negociada em um número de modos e, portanto, tem uma estrutura de emergência" ${ }^{135}$.

- Jogos de emergência com componentes de progressão: RPGs multiplayer como EverQuest são híbridos “onde a estrutura global é emergente mas contém um número de pequenas buscas onde 0 jogador tem que desempenhar uma sequência de eventos para completar a busca" ${ }^{136}$.

Embora estes diversos autores apontem a emergência como uma tendência e mais um elemento a influenciar o gameplay de um jogo, Gomes (2008:112-113) e J uul (2005:80) apontam para divergências a respeito da emergência ser efetivamente uma propriedade de um sistema (Holland 1998, 5) ou serem simplesmente situações em que o jogo surpreende seu designer (J ohnson 2001, 179-180; Rouse 2000, 124125). Para Juul é mais importante a questão de que a emergência provê o sistema de jogo com uma capacidade de surpreender os jogadores, que é importante para os jogos em si.

135 Tradução nossa. Do original em inglês: “Progression games with emergent components: The single-player action is usually a hybrid in that the player has to traverse a number of areas each of which can be negotiated in a number of ways and are therefore emergence structures". (J uul, 2005:71-72)

136 Tradução nossa. Do original em inglês: “Emergence games with progression components: Multiplayer role-playing games like EverQuest (Verant Interactive 1999) are hybrids where the overall game structure is emergent but contains a number os small quests where the palyer has to perform a sequence of events to complete the quest". (J uul, 2005:72) 
Gomes (2008:112-113) acrescenta que os autores que veem a emergência apenas como um fato ainda não compreendido pelos desenvolvedores, denominam tal acontecimento como "mero epifenômeno, algo que se dá apenas nos olhos de quem vê e por pura ignorância de alguma propriedade que está lá nas partículas fundamentais, mas à qual ainda não tivemos acesso". Para a autora, esta discussão, no âmbito dos jogos tem pretensões bem mais limitadas ${ }^{137}$.

A importância do conceito de emergência aqui, portanto, jaz entre um epifenômeno bem desenvolvido - uma ilusão convincente - e a possibilidade de criação de objetos cujos comportamentos, quando combinados entre si e, sobretudo, às ações do interator, possam servir de motor para a narrativa, ou, melhor ainda, para a vivência do interator/avatar/ personagem no mundo virtual do jogo, compondo um sistema cuja criação de sentido se dá nesse loop contínuo do qual fazem parte interator, sistema e seus diversos usos.

Acreditamos que, mais do que servir de motor para a narrativa, como Gomes afirma, o conceito de emergência se aplique, efetivamente, a incrementar a experiência do jogador, justamente por sua capacidade de surpreendê-lo.

${ }^{137}$ Gomes (2008:113) nos lembra ainda que estabelecer um limite claro entre o que é de fato uma propriedade emergente e um epifenômeno é uma tarefa ingrata, polêmica e quase impossível, que, concordamos, não nos cabe mais do que o já apresentado. 
Na construção do gameplay consideramos agência, emergência e imersão como elementos importantes, pela influência direta que têm sobre o jogador. Agência e imersão são dois conceitos ligados aos prazeres característicos do ambiente digital elencados por Murray (2003: 101-176). O terceiro citado por ela é o da transformação. Para ela,

O poder de transformação do computador é particularmente sedutor em ambientes narrativos. Ele nos deixa ávidos pelo uso de máscaras, ávidos por agarrar o joystick e virar um vaqueiro ou um combatente espacial, ávidos por entrar num MUD e assumir a identidade de GarotaElfo ou Punhal Negro. Como os objetos no meio digital podem assumir múltiplas representações, eles trazem à tona o nosso prazer pela variedade em si mesma. (Murray, 2003: 153)

Com relação aos videogames, consideramos que a emergência vai além deste prazer da transformação, pois possibilita não só a variedade em si como o surgimento de elementos inesperados e até inusitados. Por esta razão, a transformação, em nossa análise, é substituída pela emergência.

Retomando o conceito de gameplay podemos observar que este se traduz pela manipulação das regras e das mecânicas, por meio da exploração das possibilidades com as quais o jogador interage, no intuito de proporcionar a si mesmo uma experiência divertida. 
Nem todo jogo é divertido para todo mundo e o tempo todo. Mas a busca por essa diversão é o desafio colocado no momento da definição dos elementos que contribuem e interferem na construção deste gameplay.

A atitude lúdica estabelece-se pelo aceite do jogador ao convite que o jogo lhe faz. 0 apelo deste convite, que serve tanto à venda do game como elemento desencadeador da vontade de jogar, precisa sustentar-se quando o jogo é colocado em movimento.

Quando o jogo começa entram em cena outros elementos que passam a ser responsáveis pelo envolvimento do jogador e pela construção de sua experiência de jogar. As regras e a mecânica permitirão ao jogador desenvolver estratégias e táticas que caracterizarão seu próprio estilo de jogo; a narrativa (quando houver) contextualizará as ações do jogador e proverá elementos que possibilitem um engajamento emocional com os elementos do game. Os elementos da interface tanto visual quanto relativas aos comandos que o jogador utilizará são, em parte, responsáveis pela manutenção da imersão do jogador, uma vez que estes elementos precisam ser trabalhados para que esta imersão não se quebre.

Os desafios também são em grande parte responsáveis por manter o engajamento do jogador, aumentando o grau de sua imersão na mesma medida em que a agência possibilita ao jogador a sensação de estar no controle do jogo, o que pode advir da 
sua observação de que suas ações efetivamente interferem no mundo do jogo e definem (ao menos em parte) os caminhos pelos quais o jogo se desenrola.

Assim, resumidamente podemos afirmar que acreditamos que é a partir das ações que o jogador realiza dentro do ambiente do jogo (agência), combinadas com a possibilidade de encontrar caminhos impensados, que surgem da combinação das regras (emergência), e de sua imersão dentro do ambiente do jogo que o gameplay se instaura, proporcionando ao jogador uma experiência significante e divertida. 



\section{Capítulo III: As relações entre regra, gameplay e seus elementos}

“Mais que criar um ambiente flexível, o jogo deve achar a adequação perfeita entre seus objetivos e a forma como 0 jogador interage". (Assis, 2007:19)

O jogo, seja ele de que natureza for, faz um convite ao jogador para engajar-se numa atividade lúdica. Ao aceitar o convite o jogador assume a atitude lúdica, que começa pela aceitação das regras do jogo. E, se a atitude lúdica que o jogador adota depende de sua disposição de aceitar as regras do jogo, restringindo suas ações àquelas permitidas é porque estas não só restringem, mas também contextualizam e orientam as ações do jogador, desafiando-o a cumprir o objetivo do jogo dentro das restrições dadas.

Como já definimos anteriormente, as regras são

responsáveis por determinar o que o jogador pode ou não pode fazer e o que acontece em virtude de suas escolhas, orientando sua ação no sentido de produzir resultados significativos no âmbito do jogo. Declaramos que estas devem ser claras e não ambíguas de forma que sua compreensão contribua para que o jogador possa desenvolver um estilo pessoal de jogo em função de seu repertório e suas habilidades, contribuindo para que o jogo proporcione ao jogador uma experiência prazerosa e significativa. [p.96] 
As regras organizam os jogos e a experiência do jogador e da mesma forma com que jogos de tabuleiro precisam de regras que permitam aos jogadores mover suas peças, definindo os movimentos ${ }^{138}$ legais e ilegais, o videogame precisa de regras que permitam os movimentos do jogador, ao mesmo tempo em que evitam que os objetivos sejam alcançados imediatamente.

Regras e gameplay são elementos primordiais para a construção da experiência do jogador. Mas não trabalham sozinhos. Cada um dos elementos inerentes aos jogos e constituintes do gameplay tem o seu papel. É importante observar como cada um destes elementos contribui para a elaboração desta experiência.

Consideramos importante compreender o papel das regras por serem elas um importante elemento definidor das características e da originalidade de um jogo. Alterações nas regras podem gerar pequenas variações ou um jogo completamente novo, mesmo que derivado do primeiro, em função do grau das alterações que são feitas.

Vimos no capítulo anterior um exemplo de como a utilização das mesmas regras pode gerar variações muito semelhantes (como os games Bejeweled, Jewel Match, Adventure Match e Crystal Battle, que compartilham a mesma regra e as mesmas mecânicas). E também como a utilização de uma regra básica pode gerar um novo

${ }^{138}$ A palavra movimento é utilizada aqui em um sentido amplo, que vai além de 'mover-se no ambiente'. Movimento aqui também é pegar, torcer, atirar, escrever etc. O termo compreende todas as ações possíveis do jogador. 
jogo, que embora mantenha elementos semelhantes, em função de suas modificações, não pode mais ser considerado apenas uma variação. Como é o caso de havermos considerado Bejeweled (e os outros semelhantes a ele) como uma derivação do analógico Lig-4, onde o elemento semelhante é a regra de ligar um determinado número de peças, mas com regras que implementam a mecânica diferente.

A categorização das regras e as funções de cada dos seus tipos podem nos ajudar a organizar a experiência do jogador. Nesta categorização adotamos a proposta por Frasca (1997), criando uma subdivisão para as regras de desenvolvimento, que passa a ser assim representada:

\begin{tabular}{l|l}
\multirow{2}{*}{ regras de desenvolvimento } & regras regentes \\
\cline { 2 - 2 } & regras orientadoras \\
\hline regras de resultado & regras de triunfo \\
\cline { 2 - 2 } & regras de derrota
\end{tabular}

As regras de desenvolvimento são as responsáveis por guiar o desenrolar do jogo, e por isso, são em parte responsáveis por manter o engajamento do jogador. Em parte, porque as regras não trabalham sozinhas no envolvimento e engajamento do jogador, outros elementos relativos ao gameplay também devem ser levados em conta. Dentre as regras de desenvolvimento temos as regras regentes, responsáveis por determinar o funcionamento do jogo de uma forma geral, por definir o comportamento do jogador em termos do que ele pode ou não fazer e por indicar 
como suas ações se conectam. Já as regras orientadoras são responsáveis por guiar o jogador em sua busca por um objetivo, orientam suas ações no sentido de Ihe permitir estabelecer um plano de ação, as estratégias de jogo, e ajuda-o a definir seu estilo pessoal.

As regras de resultado servem para definir o resultado final dos jogos e dividem-se em regras de triunfo e regras de derrota. As regras de triunfo definem como se vence um jogo, quais são as condições em que o jogador pode declarar-se vencedor. Já as regras de derrota definem o oposto, definem as condições em que a derrota ocorre. Muitas vezes estas são inversas às regras de triunfo e nesse caso, acabam não sendo tão relevantes. Mas existem casos em que não existem regras de triunfo, uma vez que a proposta é uma superação do próprio jogador e, nestes casos, as regras de derrota têm maior importância, pois definem o final do jogo mesmo sem a vitória do jogador.

As regras e as mecânicas do jogo são sempre definidas por alguém, pelo desenvolvedor, ou no caso de muitos dos videogames pela equipe de desenvolvedores. E são, em parte, responsáveis pela ludicidade do jogo. Vale ressaltar, que a ludicidade é um importante elemento na diferenciação do jogo das atividades cotidianas. 
A ludicidade pode ser entendida como um aspecto inerente aos seres humanos, que se manifesta em atividades de lazer e recreação e por meio de jogos e brincadeiras. Esta ludicidade permite aos indivíduos atribuir um sentido lúdico ao seu comportamento quando diante de uma atividade lúdica, adotando o que já chamamos de uma atitude lúdica.

Enquanto as regras definem o espaço de possibilidades para a ação do jogador, as mecânicas de jogo regulam sua real interação com o jogo e, são modeladas por sua agência, que modifica o estado do jogo, propondo-Ihe assim um contínuo desafio em busca de seu objetivo, seja ele vencer o jogo, superar-se ou passar um tempo divertindo-se com aquela construção lúdica.

As mecânicas possibilitam ao jogador a criação de estratégicas e táticas para superar os desafios, buscando específicas transições do estado de jogo. Quando um jogo é criado, os designers criam as mecânicas básicas para os jogadores, correlacionando-as aos desafios centrais do jogo, e criando um conjunto de mecânicas úteis para a sua superação.

Da manipulação das regras e das mecânicas, através da exploração das possibilidades que o jogo oferece ao jogador, desponta o gameplay. Como já definimos, o gameplay "emerge das interações do jogador com uma determinada simulação lúdica, a partir de seu envolvimento com as regras e da manipulação de 
suas mecânicas, por meio da criação de estratégias e táticas que constroem a experiência de jogar" (pág 122).

Esta determinada construção lúdica envolve a criação de uma "estrutura jogável", que compreende elementos tais como os que consideramos essenciais aos jogos, que dividimos entre os inerentes ao jogo e os decorentes do ato de jogar. Relembrando, como inerentes, consideramos as regras e as mecânicas do jogo, os objetivos, a interação do jogador com as regras e com a arena do jogo e o fato de ser voluntário e incerto. Como decorrentes temos o gameplay, os resultados alcançados, a competição e o faz de conta que perpassam a interação do jogador com o ambiente do jogo. Estes elementos entram em cena quando o jogo começa.

Os objetivos, independentemente de serem estipulados pelo jogo ou pelo próprio jogador, guiam suas ações, e são responsáveis, juntamente com as regras e a ambiência (dadas pela definição da arena e pela narrativa, quando presente), por dar significados a essas ações, atribuindo-Ihes sentido dentro daquele universo.

Nos videogames, a arena do jogo compreende mais do que o espaço da tela visualizado pelo jogador e abrange todo o sistema de mundo no qual o jogo se desenrola. Este sistema de mundo, em geral, apresenta diversas informações ao jogador, algumas relevantes para o desenvolvimento do jogo em si, outras responsáveis pela ambientação do jogo. Os elementos responsáveis pela ambientação são importantes para o estabelecimento do senso de faz de conta, que 
torna as ações significativas dentro do ambiente de jogo, uma vez que coloca 0 jogador "dentro do jogo". Estes elementos são relevantes principalmente para os jogadores mais interessados em explorar o universo do jogo, uma vez que sem eles o ambiente correria o risco de parecer por demais estéril. No entanto, como estes elementos que nos colocam "dentro do jogo" nem sempre são imprescindíveis para o desenrolar do jogo em si, algumas vezes acabam sendo relegados pelo jogador que se concentra na execução das ações relevantes para o desenvolvimento da partida.

Este talvez seja um dos motivos que levam muitos jogadores a darem mais importância à consistência dos gráficos dos videogames do que à sua qualidade, uma vez que a inconsistência pode destruir a senso de faz de conta e romper a imersão.

A imersão, enquanto sensação que o jogador experimenta de se sentir envolvido com o jogo, possibilita-Ihe uma experiência particular, sem os riscos do mundo real. Na adaptação que fizemos dos tipos de imersão propostos por Ryan (2001:120-157), orientando-os para os videogames, podemos também observar que há um incremento de grau que acompanha a ordem de sua apresentação. Vejamos novamente esta tipificação: 
1. Espacial: o jogador compartilha o local dos acontecimentos com os personagens e/ ou demais jogadores, sente-se inserido no mundo do jogo.

Observa-se este primeiro grau de imersão no momento em que o jogador entra no círculo mágico do mundo dos jogos e deixa pra trás as preocupações cotidianas.

2. Temporal: 0 jogador acompanha 0 tempo do evento ${ }^{139}$ e engaja-se em descobrir o que virá em seguida.

Mais do que estar inserido no ambiente do jogo, o jogador envolve-se com o prazer que este Ihe proporciona desejando prolongar esta experiência.

3. Emocional: refere-se ao fenômeno do desenvolvimento de um apego pessoal aos personagens, à identificação do jogador com seu avatar no jogo.

O jogador sente-se emocionalmente apegado ao jogo de forma que assume a personalidade do seu avatar e identifica-se com ele. 0 jogador refere-se ao seu avatar em primeira pessoa.

4. Sinestésica: refere-se à aderência dos corpos dos jogadores aos movimentos do seu personagem, provocando reações em seus corpos sem passar pela atenção; diz respeito às sensações corporais provocadas pelos jogos.

Além da identificação emocional, o corpo do jogador está envolvido nas ações e reações do jogador.

${ }^{139} \mathrm{O}$ tempo do evento é aqui entendido nos termos definidos por J uul, sendo o Tempo do Evento [Event time] o tempo dos eventos em um jogo, referindo-se ao tempo em que o jogo se passa e à forma como ele decorre no jogo e que é diferente do que ele chama de Tempo de jogo [Play time], que refere-se ao tempo usado pelo jogador para jogar o jogo. 
Outro elemento importante para garantir o engajamento do jogador está na tensão que o jogador experimenta pela indefinição e incerteza impostas pelo jogo. Esta incerteza se instaura pela disputa contra um agente inteligente (seja ele um outro jogador humano ou o próprio computador que simula o comportamento deste) e pelos desafios que o jogo Ihe oferece.

Os desafios são um dos grandes responsáveis por manter o engajamento do jogador, trabalhando também para aumentar o grau de imersão na mesma medida em que a agência exercida por ele Ihe possibilita a sensação de estar no controle do jogo. Sensação esta que o jogador percebe ao observar que suas ações efetivamente interferem no mundo do jogo e definem (ao menos em parte) os caminhos pelos quais este se desenrola.

Em geral o jogo propõe uma gama de desafios ao jogador, que pode referir-se a um incremento na dificuldade do jogo, à diversidade de desafios oferecidos, à inserção de aleatoriedade ou à combinação de regras permitindo que surja um vasto número de variações (emergência).

O incremento na dificuldade, em geral, dá-se por um aumento na velocidade e/ ou na quantidade de elementos com os quais o jogador precisa lidar. A diversidade de desafios dá conta da presença de diferentes tipos de atividades apresentadas ao jogador, o que poderá Ihe exigir também habilidades diversas. A inserção de aleatoriedade aumenta a variedade dos desafios por não permitir que 0 jogador 
saiba exatamente o que lhe espera, não podendo prever a ordem e a forma com que os desafios surgirão, mesmo que Ihe seja possível saber antecipadamente qual ação será requerida. Tanto a aleatoriedade quanto a emergência que surge da combinação de regras simples (emergência como variação), ou que resultam em comportamentos muitas vezes não previstos de antemão pelo desenvolvedor (emergência como novidade ou surpresa), possibilitam uma maior rejogabilidade.

Para lidar com estes desafios, o jogador lança mão de suas habilidades e o faz por meio da agência que exerce dentro do ambiente do jogo. Agência esta que se estabelece a partir de seu envolvimento com as regras e pela manipulação das mecânicas que o jogo Ihe disponibiliza, possibilitando-Ihe o desenvolvimento de um estilo de jogar que Ihe orienta na criação de estratégias e táticas para enfrentar os desafios propostos pelo jogo. Tanto as regras como as mecânicas são agentes restritivos dessa agência, uma vez que estas definem um conjunto de escolhas possíveis, que são informadas ao jogador pela estrutura do jogo, por meio das limitações que Ihe são apresentadas.

Além das limitações que restringem a agência do jogador a uma série restrita de ações significativas, é necessário que esta estrutura também oriente o jogador tanto no sentido de deixá-lo saber onde está quanto no sentido de dar feedback às suas ações. Quando o jogador age dentro do ambiente do jogo é importante que ele perceba que suas ações influenciam esta estrutura e quais são as consequências destas ações, recebendo retornos positivos ou negativos aos seus movimentos, 
ajudando-o inclusive no entendimento das regras e do funcionamento do mundo do jogo por meio da descoberta do que Ihe é permitido e do que Ihe é vedado.

Além disso, é preciso levar em conta que o jogador depende das informações a respeito dos estados dos objetos do jogo e das relações entre eles para definir as decisões a serem tomadas, no decorrer do jogo. Estas informações são importantes para que o jogador estabeleça seu plano de ação ou, ao menos, defina o seu próximo passo. Quanto mais informações o jogador tiver, mais informada será a sua decisão, o que resultará em escolhas mais inteligentes ou mais elegantes ${ }^{140}$, além de Ihe proporcionar uma maior sensação de controle sobre o seu progresso.

Vale notar também a inter-relação que se estabelece entre os elementos que consideramos inerentes aos jogos e aqueles que fazem parte do gameplay.

A interação relaciona-se com a jogabilidade e a agência. Uma vez que haja uma boa jogabilidade, a interação do jogador com o game fica facilitada. Interação esta que se dá por meio da agência que o jogador exerce no ambiente de jogo.

\footnotetext{
${ }^{140}$ A exemplo do uso que Assis (2007:21) faz do termo elegante ao se referir a estruturas de programação que possuem "um código enxuto, no qual os comportamentos estão agrupados e hierarquizados", entendemos como elegantes as escolhas apuradas, corretas, que se harmonizam com o estado de jogo de forma proporcionada ao desafio apresentado.
} 
O fato de ser voluntário está diretamente ligado à atitude lúdica que o jogador adota ao se dispor a jogar. Pois acreditamos que o prazer de jogar reside, em parte, no fato deste ser uma atividade voluntária.

A narrativa, quando presente, trabalha em consonância com as regras, as mecânicas e os objetivos do jogo, integrando-os, atribuindo-Ihes sentido de forma a engajar emocionalmente o jogador. A arena serve de palco para o desenrolar da narrativa, ao mesmo tempo em que está ligada à interface que Ihe dá corpo. Todos estes elementos em conjunto contribuem para a imersão do jogador.

E o fator de incerteza é incrementado pela emergência de nossas possibilidades para o jogo, na maior parte das vezes traduzidas por desafios ou soluções impensadas anteriormente.

Esquematicamente, essa relação pode ser assim representada:

\begin{tabular}{|l|l|l|}
\hline Elementos inerentes ao jogo & \multicolumn{2}{|l|}{ Elementos constituintes do gameplay } \\
\hline \multirow{2}{*}{ interação } & jogabilidade \\
\cline { 2 - 2 } & agência & \multicolumn{2}{|l|}{ narrativa } & \multirow{2}{*}{ imersão } \\
\hline voluntário & atitude lúdica & \\
\hline obj etivos & & \\
\hline regras & interface & \\
\hline mecânicas & emergência & \\
\hline arena & & \\
\hline fator de incerteza &
\end{tabular}

Tabela 9. Relação entre os elementos do jogo e os constituintes do gameplay 
Estas análises são válidas para qualquer tipo de jogo, mas também é importante pensar que a existência de diversos tipos atesta a variedade de perfis de jogadores, que implica em uma diversidade de experiências de jogo. Diferentes tipos de jogos agradam a diferentes tipos de jogadores, o que implica em jogadores de diferentes personalidades, com diferentes preferências e habilidades, e que, logicamente, endereçam suas escolhas em função de suas especificidades.

Estas escolhas, manifestas por meio de suas preferências, aliadas ao seu repertório e suas habilidades, permitem que o jogador estabeleça seu estilo pessoal de jogo, percebido principalmente por meio das estratégias e táticas que ele constrói e/ ou seleciona. A criação/seleção de estratégias e táticas definidas a partir das habilidades e do repertório do jogador, combinadas com a emergência de novos elementos, surgem a partir da agência do jogador no ambiente do jogo.

Durante o desenrolar do jogo, habilidades e repertório vão sendo incrementados, tanto por meio de novas experiências quanto pelo aprimoramento de habilidades anteriores. A cada nova experiência, o estilo do jogador é posto a prova, reforçando a utilização do que se mostra eficaz, rechaçando o que não funciona e modificando ações e estratégias ainda em desenvolvimento.

Todo este processo de desenvolvimento e incremento de habilidades e ampliação de repertório constiui-se na experiência do jogador. É desejável que esta seja 
significante e divertida, incentivando-o a repeti-la. Significante, no sentido de que o jogo deve fazer sentido para o jogador, isto é, deve parecer-Ihe coerente dentro de sua própria proposta, sob pena de afastar aquele que não compreende o sentido das ações que realiza.

A coerência dos elementos do jogo com sua propostas são importantes para a manutenção da imersão do jogador. A quebra desta coerência implica na perda da imersão, uma vez que a incoerência faz o jogador desligar-se do ambiente do jogo para tentar entender o que está acontecendo.

A interação entre as regras e o gameplay (entendido em conjunto com elementos que o compõe e que nele interferem ${ }^{141}$ ) é o principal fator para o envolvimento do jogador e a construção de sua experiência de jogar. As regras e a mecânica permitirão ao jogador desenvolver estratégias e táticas que caracterizam o seu próprio estilo de jogo. A rapidez com que o jogador se sente a vontade com o jogo depende das características de jogabilidade, em especial, da curva de aprendizagem apresentada pelo game. A arena e, principalmente, a narrativa (quando houver) contextualizarão a agência do jogador provendo elementos que possibilitem um engajamento emocional com os elementos do game. 0 engajamento emocional traduzirar-se-à pelo tipo e grau de imersão. Os elementos da interface tanto visual quanto relativas aos comandos que o jogador utilizará serão, em parte,

${ }^{141}$ Consideramos como elementos que fazem parte do gameplay: atitude lúdica, jogabilidade, narrativa e interface. E como elementos que nele interferem: imersão, agência e emergência. 
responsáveis pela manutenção da imersão, uma vez que estes elementos precisam ser trabalhados para que esta não se quebre.

Assim, quando o jogo apresenta ao jogador, imerso no ambiente do jogo, um desafio, este Ihe possibilita, por meio da manipulação das mecânicas e da combinação das regras, a experimentação da emergência de novos elementos, que surgem de sua agência sobre o jogo. Agência que se traduz pela realização de ações significativas, geradas a partir de escolhas informadas e possibilitadas pelas informações disponibilizadas pelo sistema. Informações que são organizadas a partir da interação entre os elementos do jogo, as regras e o gameplay.

Este processo não só incrementa as habilidades e o repertório lúdico do jogador como the possibilita experimentar a atividade do jogo como significante e prazerosa, contribuindo para que o convite a participar deste ou de outros jogos seja continuamente reforçado e aceito.

O papel destes elementos na construção deste processo de engaj amento do jogador pode ser observado na análise do videogame Cozinheiro das Almas. 



\title{
Capítulo IV: Análise do game Cozinheiro das Almas
}

\author{
"Muito da arte entrará nestes temperos, arte e paradoxo, \\ que, fraternalmente se misturarão para formar, no ambiente \\ colorido e musical deste retiro, o cardápio perfeito para o \\ banquete da vida". (J oão de Barros*)
}

A partir do livro "O Perfeito Cozinheiro das Almas deste Mundo", diário da garçonnière mantida por Oswald de Andrade entre 1918 e 1919, o Grupo de Pesquisa em Poéticas Digitais (ECA-USP) iniciou o desenvolvimento de um videogame no qual o personagem principal se perde na São Paulo de 1918 e visita interativamente vários ambientes nos quais vai aos poucos descobrindo a trama. Tudo se passa em um só dia. Dessa forma, é um roteiro de ambiente virtual duplamente labiríntico: são labirintos espaciais (os vários ambientes) e temporais (pois as tramas dentro de cada ambiente são lineares, mas o jogador pode aportar nelas em qualquer fase de seu desenvolvimento).

Assim é apresentado o game Cozinheiro das Almas. 0 jogo faz referência ao diário aberto que Oswald de Andrade manteve entre 30 de maio e 12 de setembro de 1918, publicado com o título de "O Perfeito Cozinheiro das Almas deste Mundo". Neste mesmo período, Oswald manteve um romance com a normalista Maria de Lourdes Castro de Andrade, também chamada de Deisy e Cyclone. No diário, um caderno guardado em sua garçonnière, na rua Líbero Badaró, 67, 3o andar,

\footnotetext{
* do livro 0 perfeito cozinheiro das almas deste mundo. [ANDRADE, Oswald de. O perfeito cozinheiro das almas deste mundo. São Paulo: Globo, 1992. (Obras completas de Oswald de Andrade)].
} 
escreviam, além de Oswald e Deisy, e sempre sob pseudônimo, Monteiro Lobato, Guilherme de Almeida, entre outros.

o Grupo de Pesquisa em Poéticas Digitais criou, em torno desse diário, o roteiro de um ambiente virtual interativo, "no qual Deisy e a garçonnière de Oswald vão precipitar as pessoas numa viagem à São Paulo de 1918, fazendo-as se perder em um labirinto temporal" (Prado et all, 2006:1).

O jogo foi concebido no final de 2004 e desenvolvido entre 2005 e 2006 . A equipe inicial, responsável pelo game, era assim composta:

Coordenação: Gilbertto Prado

Argumento: J esus de Paula Assis

Roteiro: J esus de Paula Assis, Paula J anovitch e Gilbertto Prado

Design: Lívia Gabbai, Eduardo Hulshof e Luciano Gosuen

Vídeo: Maurício Taveira, Luciano Gosuen e Fábio Oliveira

Programação: Marcos Cuzziol, J ohnPhilip J ohansson, Gaspar Arguello, André Furlan, Eliane de Oliveira Neves e Leandro da Silva Soares

Apoio: Raul Cecílio.

Nesta época, o Grupo de Pesquisa em Poéticas Digitais da ECA USP, contava também com a participação de outros artistas/pesquisadores, que discutiam questões sobre interface e interatividade: Silvia Laurentiz, Monica Tavares, Cézar Hirashima e Martha Carrer Gabriel. 
Com o tempo, houve alterações na equipe. No final de 2005, Hélia Vannucchi passou a integrar a equipe do design. Em 2006 o Grupo deixou de contar com J ohnPhilip J ohansson, na programação e com Eduardo Hulshof, no design.

O game Cozinheiro das Almas foi premiado na 6a edição do Prêmio Sergio Motta de Arte e Tecnologia (2005/06). A versão demo deste trabalho foi exibida na Mostra exposição coletiva, Interconnect@ between attention and immersion, ZKMZentrum für Kunst und Medientechnologie, Karlsruhe - Alemanha, de 01 de setembro a 15 de outubro de 2006, curadoria Peter Weibel e Daniela Bousso, coord. Bernhard Serexhe e também na Exposição Arte Computacional e Pesquisa, Espaço Cultural 508 Sul, Brasília, curadoria de Suzete Venturelli, em 2007. Nestas versões foram construídas a garçonnière, em 2006 e 1918, assim como a Escola Normal e 0 J ardim da Infância, em horários distintos, o que permitiu ao visitante experienciar a poética do trabalho, percorrer os espaços criados e jogar em pelo menos dois ambientes.

Na época desta versão do game faziam parte do Grupo: Gilbertto Prado, J esus de Paula Assis, Paula J anovitch, Lívia Gabbai, Luciano Gosuen, Fábio Oliveira, Gaspar Arguello, André Furlan e Hélia Vannucchi. Além dos integrantes, o grupo também teve a colaboração de Ricardo Irineu de Souza, André Kishimoto, Rafael Rodrigues, Sílvio Valinhos, Mônica Ranciaro, Natália Gagliari, Paula Gabbai, Marcos Cuzziol, Maurício Taveira e Eliane de Oliveira Nunes. 
A proposta inicial incluía a construção de 10 ambientes:

1. a própria garçonnière

2. o Teatro Municipal

3. a casa de um barão, na avenida Paulista

4. a Escola Normal

5. o Conservatório Dramático e Musical de São Paulo

6. um bonde

7. um mercado

8. um quarteirão pobre no Brás

9. uma delegacia de polícia

10. um centro de poder (a Assembléia Legislativa).

E embora apenas os ambientes da garçonnière, da Escola Normal (incluindo o J ardim da Infância) tenham sido efetivamente implementados, a mecânica proposta pode ainda assim ser observada.

Durante todo o desenvolvimento do game houve uma grande preocupação com a referência histórica. Pesquisas foram feitas buscando recriar o ambiente da época, procurando detalhar como eram os locais em 1918, os objetos utilizados, como as pessoas se vestiam, como se comportavam, quais eram os temas das discussões, o 
que estava nos jornais, entre outros. As principais fontes primárias foram o Arquivo do Estado e o Centro de Referência Mário Covas ${ }^{142}$.
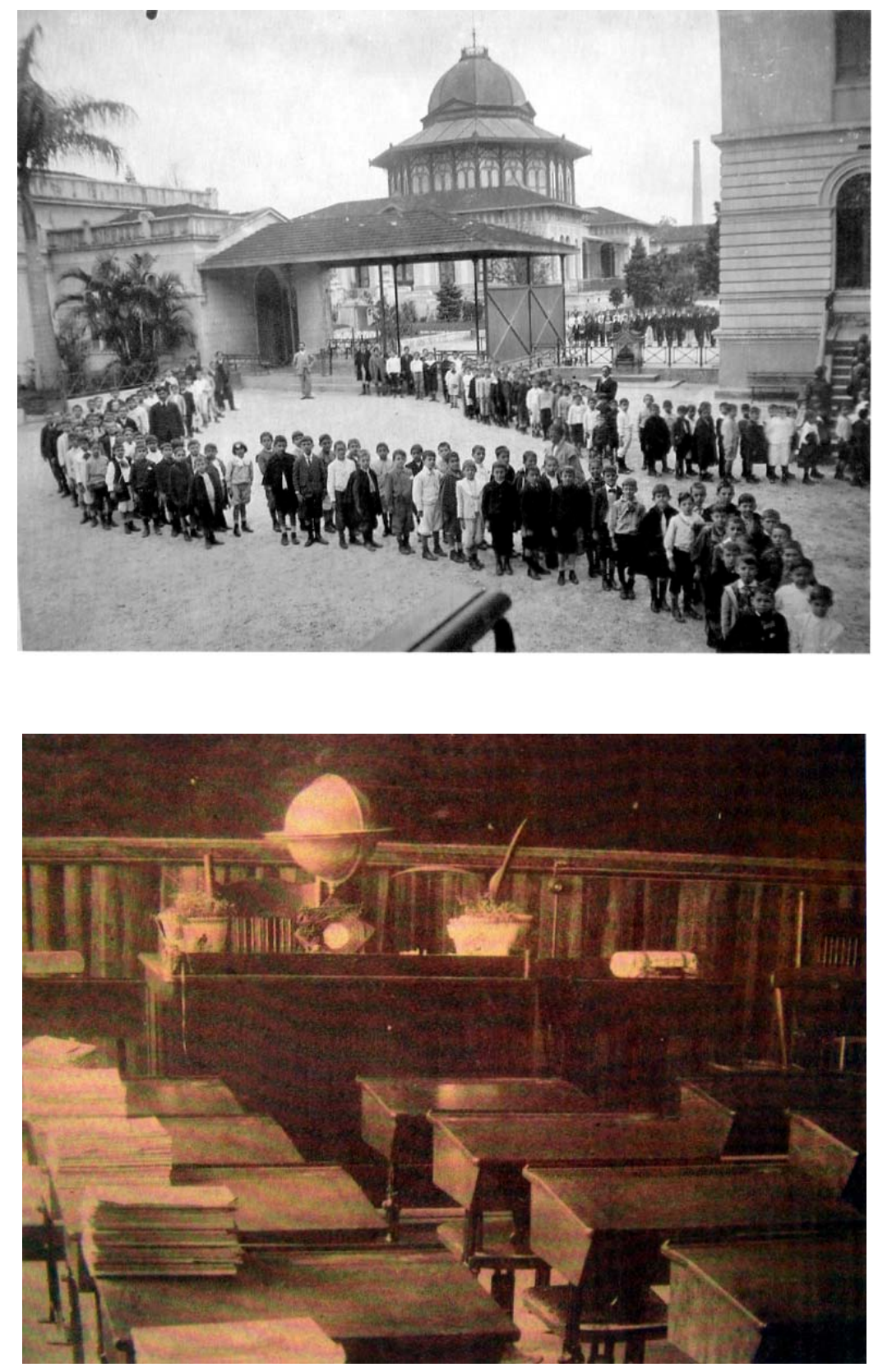

Figura 18. Imagens de referência para o game

${ }^{142}$ A relação do material mais relevante utilizado durante as pesquisas encontra-se no final deste capítulo. 
Foram levantados mapas da cidade desse período. Do Brás, plantas de um cortiço e de casas de operários foram obtidas, e que direcionaria o trabalho de arte na construção desse ambiente. A principal referência para a fachada das vilas operárias veio do livro de Dulce Soares, Barra Funda: esquinas, fachadas e interiores.

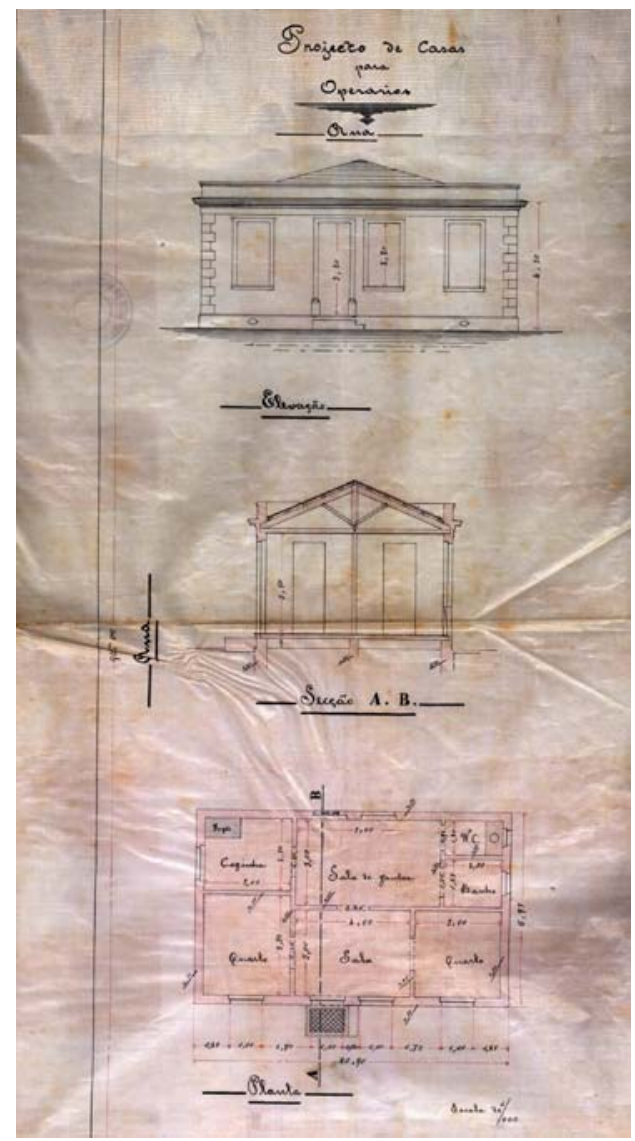

Figura 19. Projeto de casa para operários

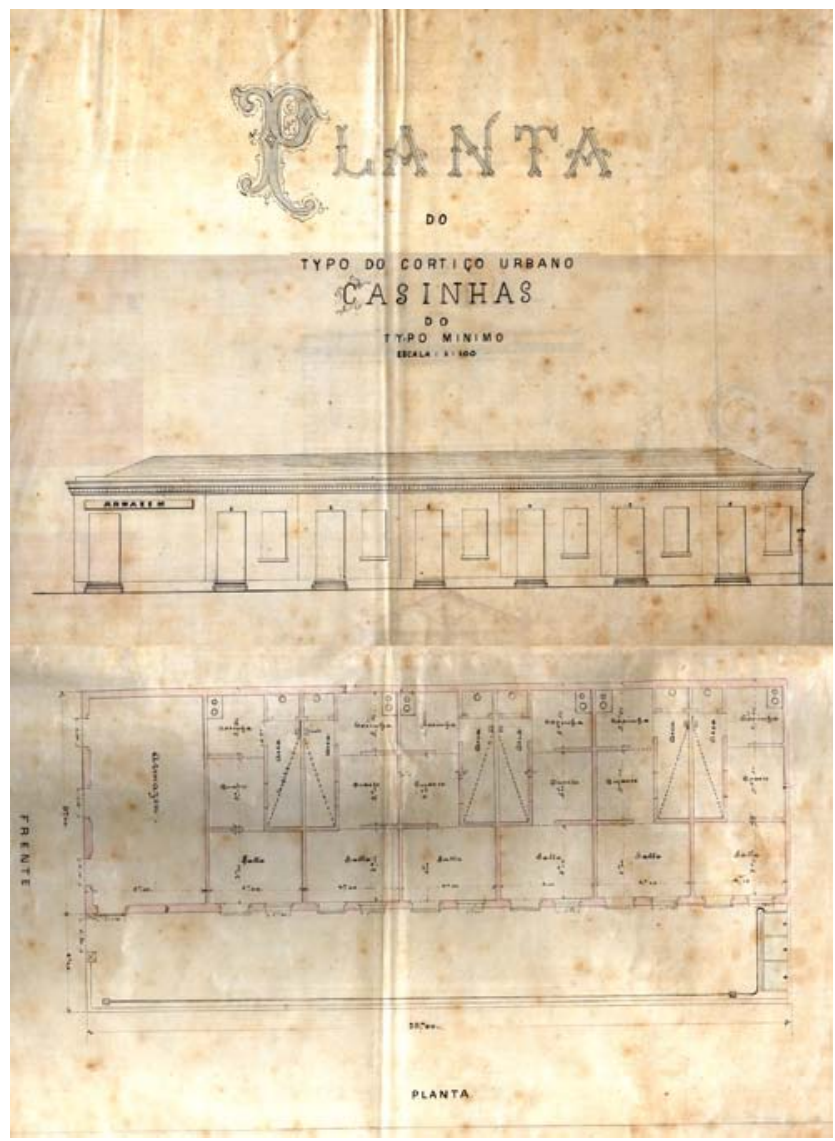

Figura 20. Casinhas do tipo mínimo

Em torno da Escola Normal a pesquisa foi ainda mais detalhada, foram obtidas a planta do edifício relativa ao período em que o jogo se passa e uma grade de atividades da escola, também do mesmo período. Três edições do Relatório do Director da Escola Normal, publicados pela Tipografia do Diário Oficial, 
especificamente as de 1893, 1895 e 1896, forneceram cerca de 500 páginas de textos e tabelas que embasaram a modelagem dos objetos da Escola Normal. Além das diversas fotos de arquivo obtidas durante a pesquisa, a Escola também foi fotografada para que detalhes de sua arquitetura fossem fielmente retratados na modelagem.

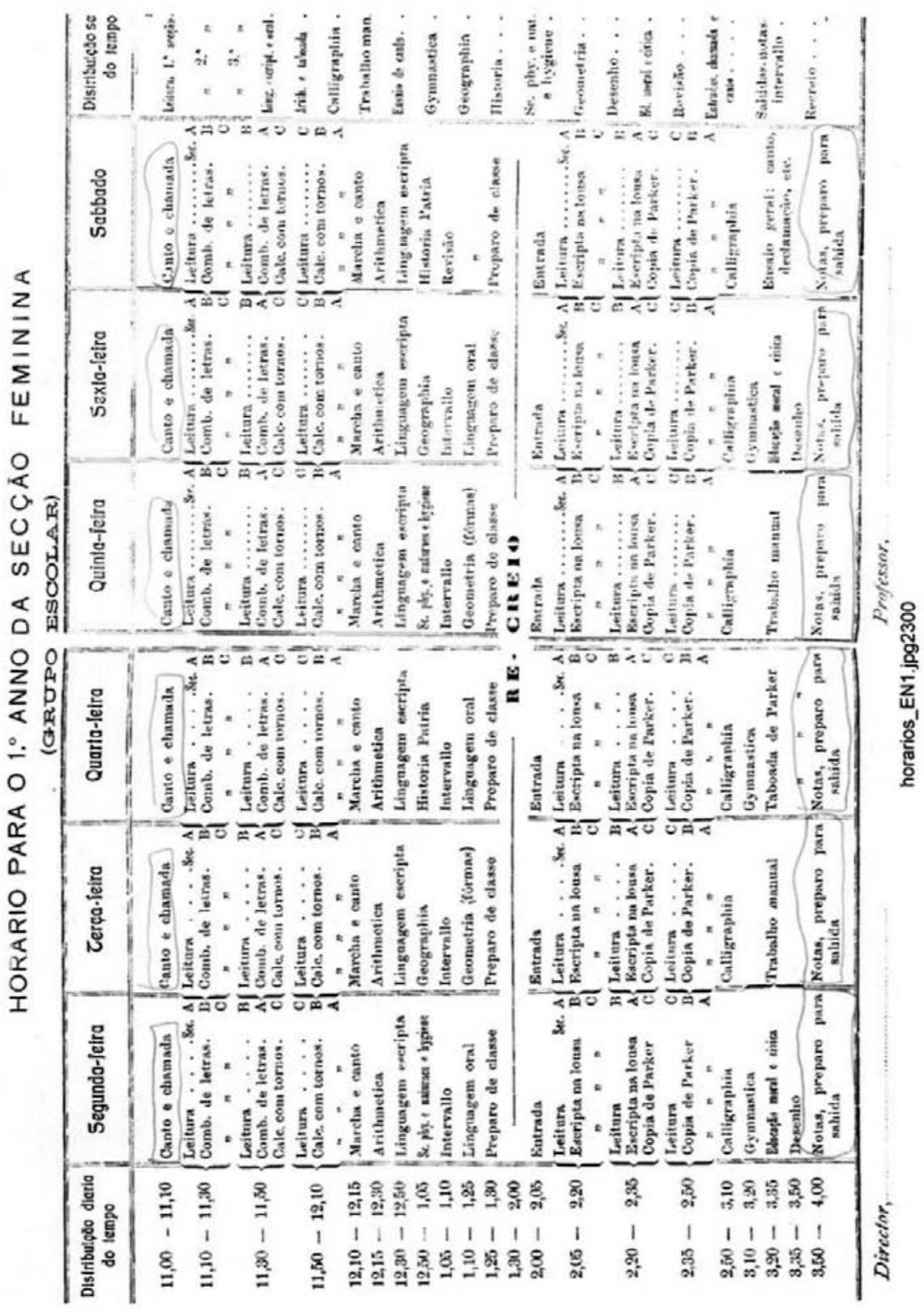

Figura 21. Atividades do Grupo Escolar, c. 1818. 
A pesquisa a respeito da Escola Normal incluiu a busca por informações sobre o antigo J ardim de Infância, que funcionava anexo à Escola. A melhor descrição em texto do lugar foi encontrada no livro A cidade de São Paulo em 1900, de Alfredo Moreira de Pinto.

Tudo isso porque o jogo tinha por objetivo criar um ambiente ficcional de ação que fosse também historicamente preciso.

\subsection{Elementos do jogo}

Regras, mecânica, objetivos, arena e fator de incerteza são elementos que constroem o jogo e serão detalhados a seguir.

\section{- Regras}

As regras do jogo são algo que o jogador vai descobrindo aos poucos, conforme explora o ambiente do jogo. Ele pode andar por ele, mas não abre nenhuma porta. Pode ver e ouvir as pessoas, mas não é visto por elas. 0 jogador esbarra nos objetos que encontra e pode pegá-los. As garrafinhas de líquido verde garantem mais tempo de permanência no ambiente. 0 objeto a ser reposto na garçonnière, quando encontrado, o leva de volta a ela.

O jogador também pode desistir, e desistindo pode passear não interativamente pelos ambientes, na sequência temporal correta. No entanto, nesse passeio, o 
jogador não pode ver os objetos espalhados que precisa resgatar. Assim, o passeio não perde o seu prazer exploratório, mas também não estraga o prazer do jogo.

\section{- $\quad$ Mecânica}

O jogo é labirinto temporal e espacial, puramente exploratório, mas com uma "missão", que o jogador descobrirá durante o decorrer do jogo, sem ter de ser instruído a respeito. 0 jogo se passa em um único dia ( 25 de julho), que é dividido em seis seções de duas horas (10 às $12, \ldots$, até 20 às 22 ).

A mecânica do jogo, resumidamente, consiste nas viagens que o jogador faz para explorar os ambientes e resgatar objetos para recompor a tessitura do tempo, evitando que este se rompa destruindo o tempo atual.

Na ideia inicial, a garçonnière funcionaria como um "mapa" que inventariaria os objetos a serem resgatados e poderia ser consultado de tempos em tempos, voluntariamente, pelo jogador. O jogador viajaria sempre de seção em seção temporal, fora de ordem, nos vários ambientes. No entanto, a mecânica que foi implementada acabou tendo uma estrutura muito mais modesta, que pode ser assim resumida:

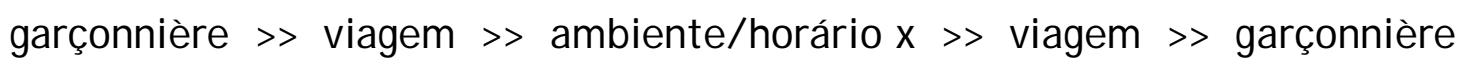


Quando o jogador toca em um objeto na garçonnière, ele é transportado para um outro ponto do jogo. Nesse momento, a garçonnière se fragmenta e o objeto tocado recua e se funde ao ambiente deste outro ponto do jogo onde o jogador foi lançado, indicando ao jogador que encontrar este objeto, a fim de repô-lo na garçonnière é sua missão ali.

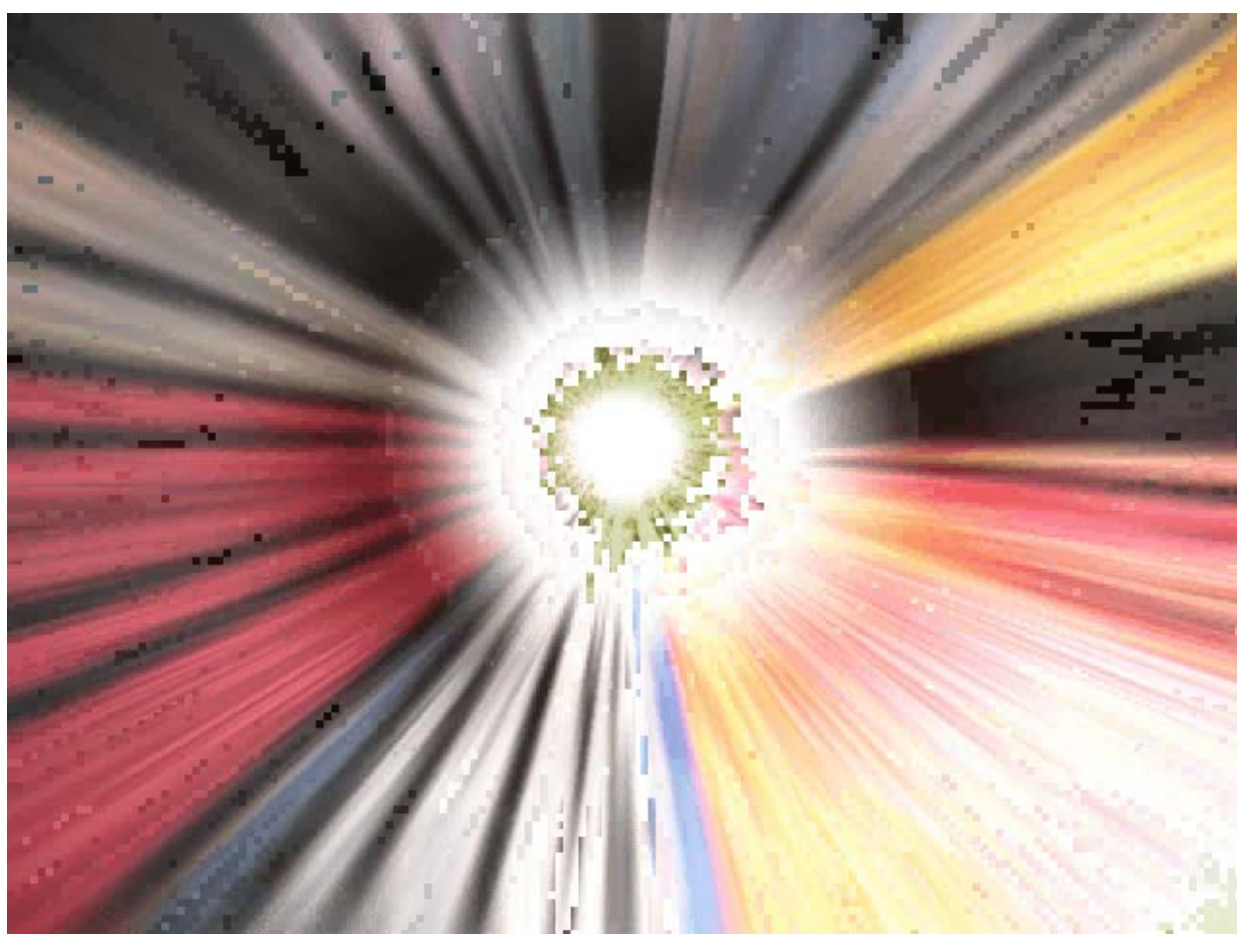

Figura 22. Túnel do tempo que transporta o jogador para os diversos pontos do game

\section{- Objetivos}

O jogo tem duas motivações distintas, mas que se entrelaçam: a exploração do ambiente e a procura por objetos perdidos no passado, para recolocá-los em seu lugar, no tempo presente, sob pena de destruir a tessitura do tempo e com isso destruir o tempo presente como o conhecemos. 
O interesse pela exploração fica a cargo da qualidade gráfica das reconstituições de época dos lugares e pelo interesse que os diálogos, que o jogador escuta, possam Ihe suscitar.

O objetivo de recolher os objetos é dado a perceber ao jogador quando ele é arremessado na Escola Normal, às 19 horas e ouve uma palestra que trata dos problemas na viagem do tempo e de como objetos de uma época podem ser destrutivos em outra. Além de trechos de fala, essa informação também está presente nos slides projetados durante a palestra.

\section{- $\quad$ Arena}

Em cada ambiente do jogo, existe uma história subjacente ao jogo que ambienta o jogador à época de Oswald e Deisy. Existe uma ligação entre todas as tramas dos diversos ambientes, que pode ser percebida, inclusive pela presença de alguns personagens que aparecem em vários ambientes, e em diferentes momentos.

A garçonnière é o ponto de partida do game, o local de encontro de Oswald e Deisy, é também o local de onde o jogador é arremessado de volta no tempo, em busca de objetos que reconstituam o ambiente e recontem a época em que estes amantes viveram, ou seja, a São Paulo de 1918. A inspiração para sua ambientação veio, principalmente da coletânea de contos organizada por Beatriz Resende, Cocaína - 
literatura e outros companheiros de ilusão e da noveleta de Hilário Tácito, Madame Pommery.

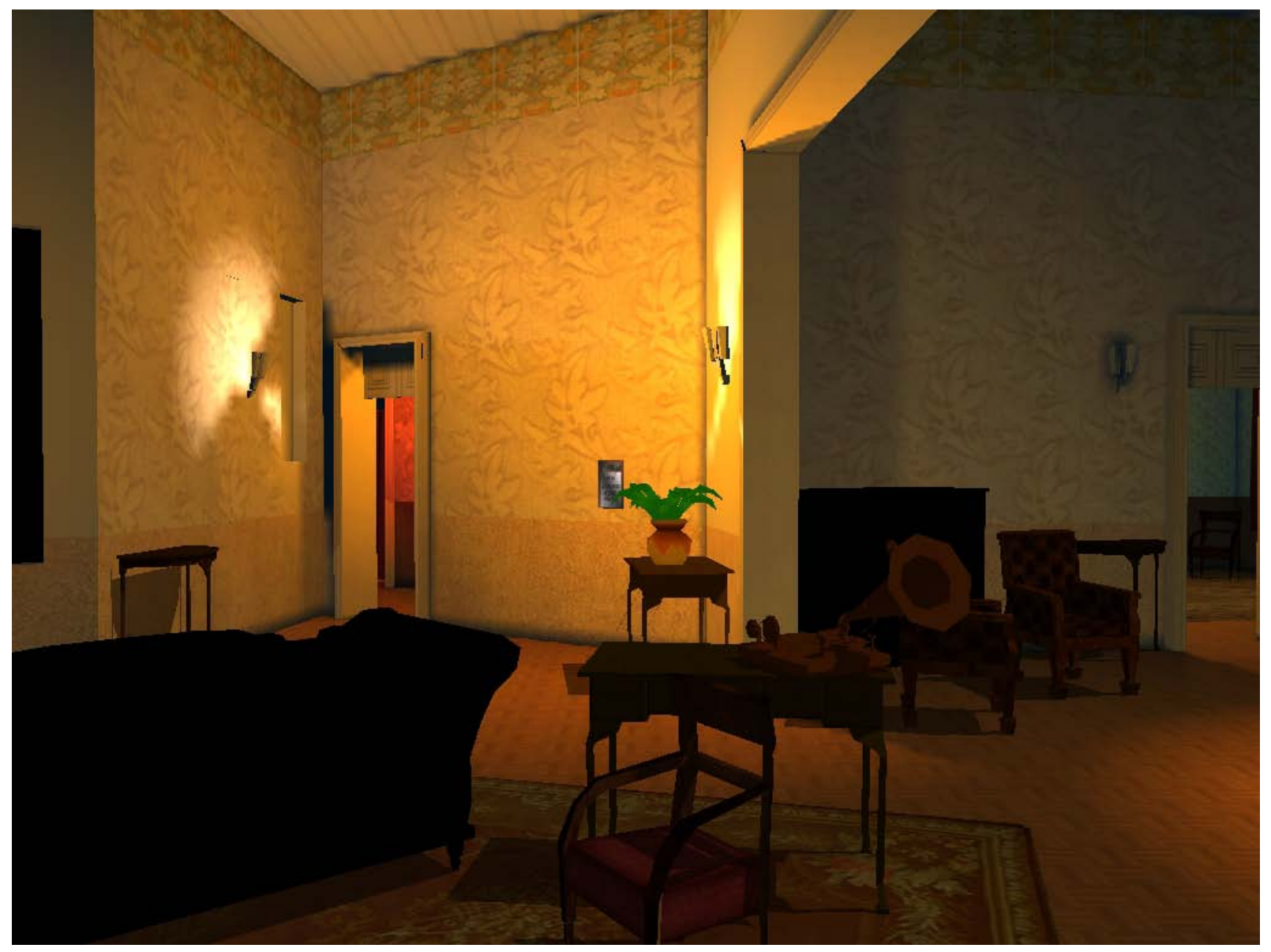

Figura 23. Imagem do jogo, a garçonnière em 1918.

Quase todos os ambientes inicialmente propostos para o jogo têm suas ações principais definidas. Sendo a Escola Normal o único ambiente (além da garçonnière, é bom frisar) desenvolvido, suas histórias subjacentes estão mais detalhadas. Vejamos primeiro os demais ambientes para depois nos atermos à Escola Normal.

No Teatro Municipal, um espetáculo que acontecerá às 20 horas está sendo preparado. Até o momento da apresentação, as ações se passam nos bastidores e na 
hora do espetáculo, as ações do jogo desenvolver-se-iam ou nos camarotes ou nos bastidores.

Na casa de um barão, na avenida Paulista, a família se prepara para homenagear um artista conservador. Uma das filhas do barão manifesta seu descontentamento, pois preferia um outro homenageado. As ações, aqui, vão dos preparativos à festa.

No Conservatório Dramático e Musical de São Paulo, este é um dia especial. Mario de Andrade organiza uma noite dedicada a formas de música popular como 0 maxixe e o choro.

No mercado (ou em uma loja de secos e molhados) a ação inicialmente proposta envolvia um furto, e apresentava o lugar como um local de encontro de imigrantes.

A ação envolvendo a estação de bondes inicia-se no bonde em que o jogador está que quebra e vai para a gare. Neste espaço não há distinção entre as ações principal e secundárias. Da gare, as pessoas se dispersam e os mecânicos trabalham.

Na delegacia de polícia dois assuntos são os temas centrais: o consumo de absinto e a censura. 
Na Assembléia Legislativa, a discussão é a respeito da reforma urbana e seus inconvenientes, entre eles, as demolições necessárias à modernização da cidade.

As ações que se desenrolariam no quarteirão pobre do Brás não foram definidas.

No entanto, a ideia era mostrar a casa de um dos namorados de Deisy, pertencente à classe baixa e um lugar de consumo e compra de absinto.

Na Escola Normal, o dia é ocupado pelos preparativos para a palestra das 18 horas, em que Amoroso Costa falará sobre as recentes descobertas na física (e entre estas, a ideia de viagem no tempo). Pela manhã, além dos preparativos, salas estão ocupadas com as aulas. Terminadas as aulas alguns alunos se mobilizam preparando um abaixo-assinado contra um professor muito conservador. 0 abaixo-assinado é entregue, mas a palestra da noite adia a decisão do diretor. Concomitante a esses acontecimentos algumas ações secundárias se desenrolam, como o consumo de absinto por alguns alunos que se escondem no porão da Escola, e os preparativos tanto no anfiteatro quanto na recepção, à espera do palestrante. 


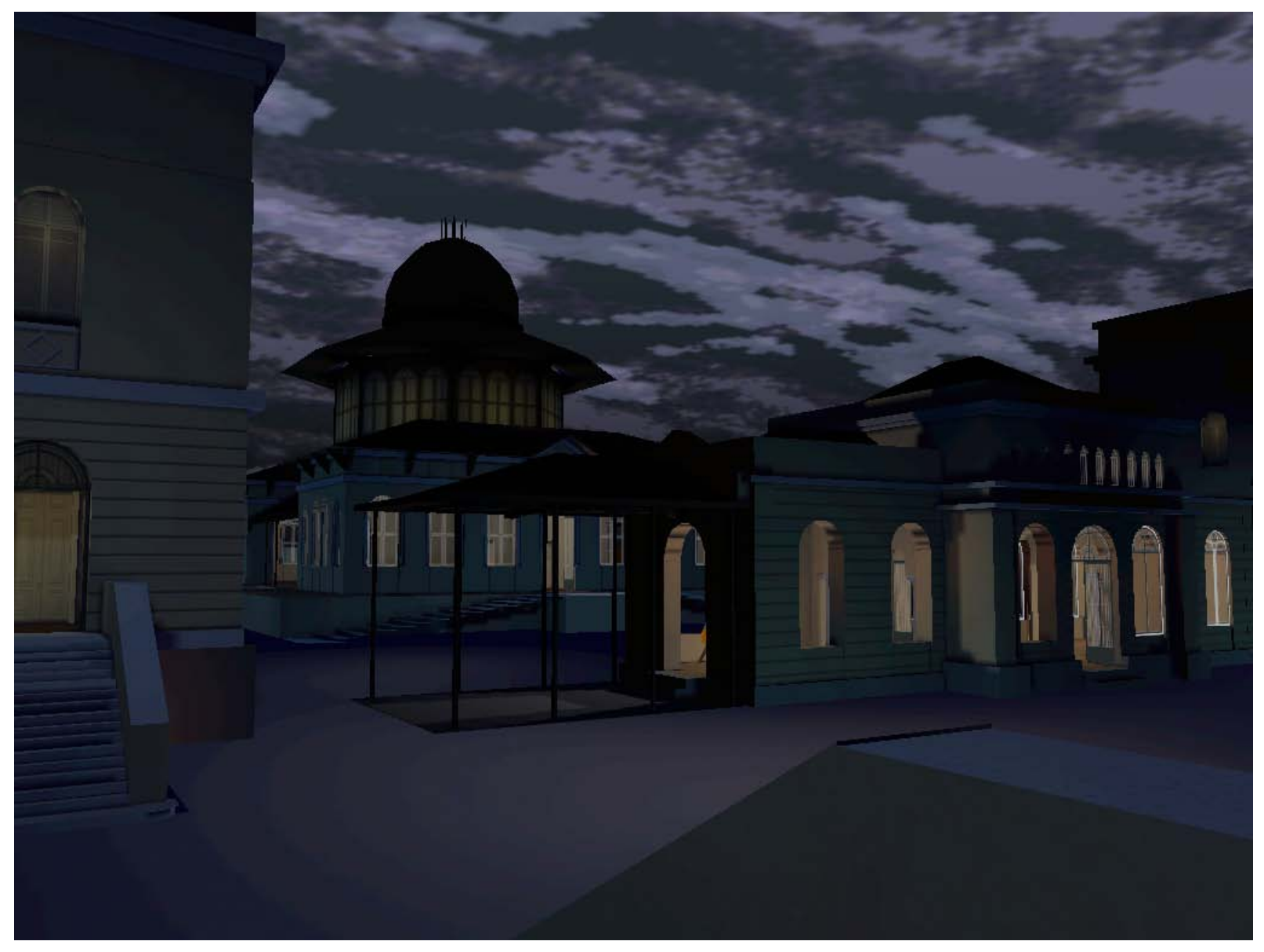

Figura 24. Imagem do jogo, Escola Normal e J ardim de Infância.

\section{- $\quad$ Fator de incerteza}

É dado pelo caráter labiríntico do jogo tanto espacial, quanto temporal, uma vez que o jogo arremessa o jogador a um dado momento, de um dado ambiente do jogo.

Mesmo que o jogador saiba para onde está sendo arremessado, em função do objeto em que toca na garçonnière (pelo menos se estiver tocando-o novamente), não é possível saber a que faixa horária será levado. 
Esse caráter labiríntico fica tão mais intrincado a quantos mais ambientes são implementados, obrigando o jogador a se organizar também temporalmente dentro dos ambientes, reconstituindo as ações subjacentes ao jogo a partir das frases e das indicações recolhidas durante suas explorações.

Como o jogo ficou restrito a sua primeira fase, com apenas um ambiente além da garçonnière, a saber, a Escola Normal, o fator incerteza restringiu-se ao labirinto espacial que o jogador percorre.

\subsection{Elementos de interação}

A interação do jogador passa pela presença de objetos e personagens que o jogador encontra durante o seu percurso e que the permitem algum tipo de agência. Os movimentos que Ihe são permitidos, assim como os indicativos de orientação e feedback que o jogador recebe são outros elementos que serão detal hados a seguir.

\section{- Objetos e personagens}

Os ambientes e os objetos foram construídos com o máximo de realismo que 0 engine utilizado permitiu, enquanto os personagens são mais estilizados. Isso não significa que sejam caricaturas, mas estilizações de imagens correntes da época, presentes em ilustrações, charges, etc., que ilustram a maneira como as pessoas se viam e se retratavam. 


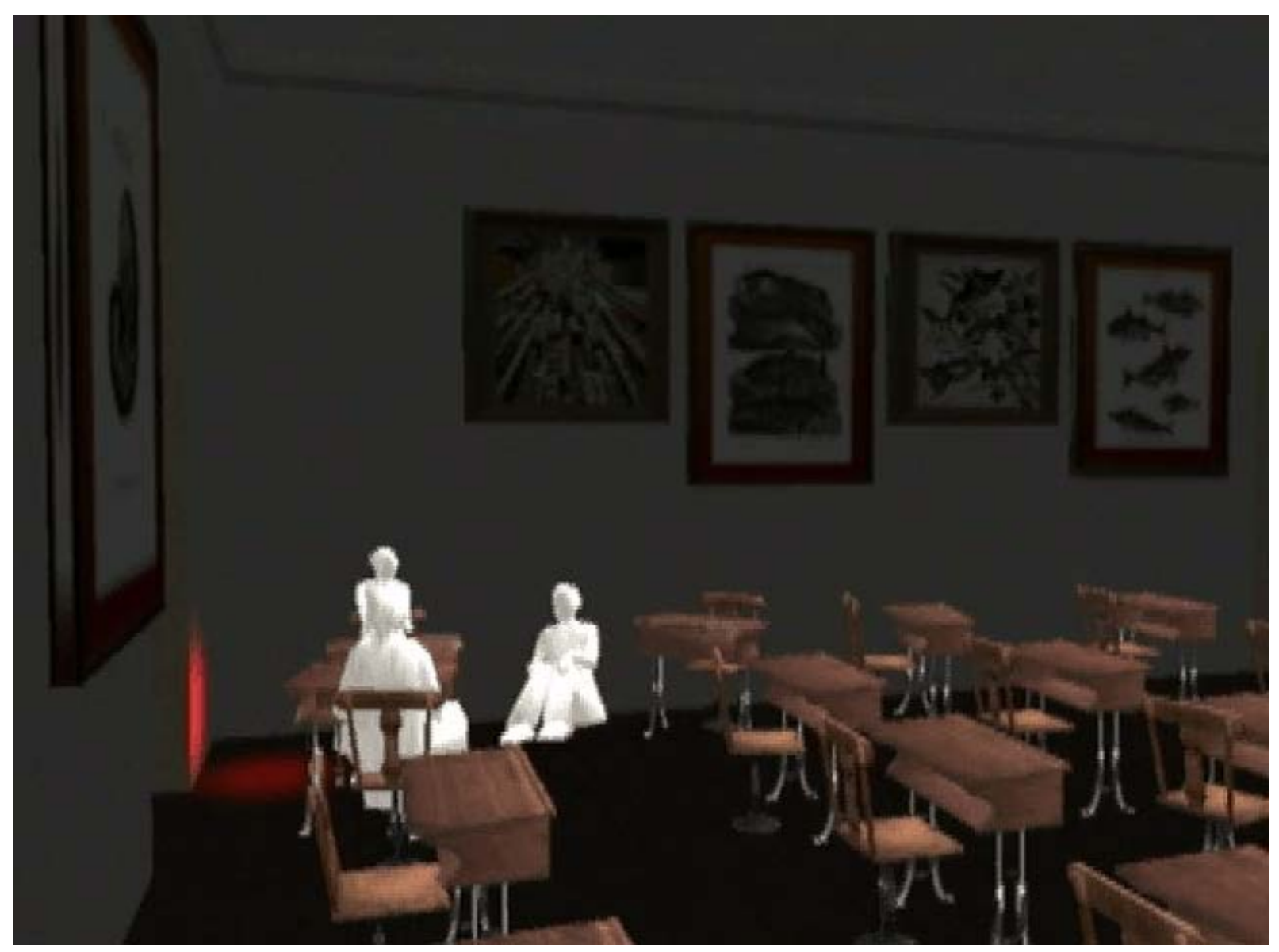

Figura 25. Imagem do jogo, grupo de personagens na Escola Normal.

O fato de o jogo abordar uma época específica e fazer referências a pessoas que existiram criou uma limitação, principalmente na reprodução da expressão dos personagens. A estilização e o congelamento dos personagens revelaram-se tanto como uma boa solução técnica quanto como uma solução visual bastante interessante. A estética dos personagens foi inspirada nas esculturas de George Segal. 


\section{- Movimentos}

As ações básicas do jogador são andar, mover a cabeça, pegar e mover coisas. Durante sua exploração dos ambientes, o jogador encontra pessoas que conversam em pequenos grupos, mas tudo o que ele ouve são texturas de sons, palavras e frases soltas pelo grupo, que permanece parado, como se fossem estátuas. E isto enquanto o jogador se mantém a uma certa distância deles, pois eles param de falar se o jogador se aproxima muito.

Das frases ditas pelos grupos, na aproximação máxima que o jogador consegue antes que o grupo pare de falar, ele pode conseguir ouvir uma frase inteira. Estas frases inteiras dão pistas da trama subjacente ao jogo, enquanto as texturas de som preenchem 0 ambiente.

Para que o jogador se situe dentro das faixas horárias em que está e assim se situe na ação que se passa ao seu redor, os relógios marcam horas certas. Se o jogador não se deu por satisfeito com a exploração em um determinado ambiente, pode voltar, quantas vezes quiser, àquele local, tocando, na garçonnière, no mesmo objeto que o levou até lá. 0 que não significa, no entanto, que ele chegue ao local, no mesmo intervalo de tempo que já percorreu.

Espalhadas pelo ambiente, o jogador irá encontrar diversas garrafinhas com líquidos verdes, que Ihe permitem, ao ingerir o seu conteúdo, ter uma visão mais clara de onde estão os objetos-alvo de sua missão. Este conteúdo verde é uma referência ao 
absinto, bebida consumida pelos jovens da época em que se passa o jogo. No entanto, esta referência é indireta e não é explicitada durante o jogo.

\section{- Orientação e feedback}

Quando o jogador é teletransportado para um ambiente, ao invés de chegar diretamente a um ponto do jogo, ele primeiramente faz um voo, de aproximadamente 10 segundos, pelo local. Neste voo é como se o jogador fosse um fantasma, que voa e atravessa paredes. Esse sobrevoo permite ao jogador ver 0 lugar por uma perspectiva que não terá novamente quando estiver andando por ele, mas de alguma forma, também o ajuda a se orientar.

Outro elemento de orientação refere-se à vida do jogador, no caso do jogo, ao seu tempo de permanência em um ambiente. Quando este começa a acabar, seus passos ficam mais lentos e sua visão embaça. No entanto, se no momento em que sua vista estiver começando a embaçar, o jogador passar por uma das garrafinhas e ingerir o líquido verde, ele ganha mais tempo. Sua vista desembaça, seus passos voltam ao normal e seu tempo de exploração recomeça. Este sistema orienta 0 jogador com relação ao que, na maioria dos jogos, seria o nível de energia ou saúde do jogador, sem, no entanto, precisar fazer uso de nenhum placar e apresentando uma consequência em função do baixo nível dessa energia ou saúde. 


\subsection{Resultados}

O jogo tinha por objetivo criar um ambiente ficcional de ação que fosse também historicamente preciso, este objetivo foi alcançado em função da cuidadosa pesquisa histórica que o embasou.

Enquanto ambiente de ação, o jogo pretendia se configurar como um labirinto espacial e temporal, puramente exploratório, que não instruiria o jogador na missão que este deveria descobrir enquanto se aventurava pelos ambientes. 0 que observamos com relação a este ponto é que o jogo atende melhor a jogadores mais experimentados em outros jogos de exploração, deixando os novatos um pouco desorientados. No entanto, esta desorientação se desfaz depois de um certo tempo de errância e de algumas ações que obedecem mais ao parâmetro de tentativa e erro.

A ausência de placares intrusivos, que atrapal hassem a imersão do jogador foi outro dos objetivos do game. E, embora não haja placares, o jogador tem meios de saber quando deve procurar uma garrafinha verde (ao menos após ter experimentado uma) para aumentar seu tempo de permanência em um ambiente, em virtude das imagens se apresentarem turvas (vista embaçada) e do caminhar do jogador se tornar mais lento. 
Após as ponderações acerca dos objetivos do game, podemos proceder com 0 estabelecimento das conexões entre os elementos já analisados, partindo das interrelações entre os elementos do jogo e aqueles que fazem parte do gameplay.

As regras e mecânica de 0 Cozinheiro das Almas possibilitam uma experiência altamente exploratória, uma vez que o game consiste nas viagens que o jogador faz para explorar os ambientes e resgatar objetos. O caráter exploratório do jogo é reforçado pelo próprio fato de que regras e o objetivo do jogo não são dados a priori, mas como algo que o jogador vai descobrindo aos poucos.

Ser lançado a um momento que não se sabe qual, dentro de um espaço labiríntico, garante ao jogador diversas opções de exploração. Reconhecemos que o jogo possibilitaria uma emergência maior de desafios, se mais ambientes fossem implementados, aumentando a complexidade de seus labirintos espaciais e temporais.

A atividade exploratória mostra-se intuitiva, uma vez depende de poucos comandos e segue os padrões já estabelecidos em outros jogos do gênero. 0 fato de o jogo possuir poucos comandos e que seguem os padrões já estabelecidos auxilia na manutenção da imersão, no sentido de que o jogador já habituado a eles se sente rapidamente ambientado ao jogo. 
Após um curto período de tempo, quando o jogador compreende sua missão, estabelece-se um nexo entre as ações e suas consequências, como por exemplo, quando o final do intervalo de tempo de uma dada sessão de jogo é comunicado ao jogador, por meio de uma espécie de vertigem, ou pela associação possível de que o líquido verde, o absinto, vai Ihe afetar a percepção, ampliando-a naquele mundo (uma vez que seu consumo estende seu tempo de permanência no ambiente em que o jogador se encontra).

A coerência do sistema de orientação, que dispensa placares que distraiam a atenção do jogador, auxilia na preservação da imersão. 0 game apresenta ao jogador esta contagem de saúde ou tempo de permanência na sessão de forma metafórica, como uma consequência de sua baixa energia, com o personagem do jogador apresentando sensações semelhantes à de um corpo prestes a desmaiar, com um caminhar mais lento e a visão embaçada.

A agência do jogador é contextualizada pelas histórias subjacentes e, como quem delineia a figura de um quebra-cabeças conforme junta suas peças, o jogador vai construindo a história enquanto vai descobrindo as peças da trama por meio de sua exploração. Estas peças são as frases soltas que o jogador ouve ao se aproximar de um grupo de personagens, estão nos elementos e objetos que povoam os ambientes, dando-Ihe indicativos da época e do contexto das histórias e, inclusive, na orientação inicial que o jogador recebe de forma não impositiva ao ser levado, no início do jogo, para uma palestra em que o tema é a viagem no tempo. 
A interface gráfica, com o ambiente realista e personagens imóveis e estilizados, e os poucos comandos, iguais aos mais usuais na maioria dos videogames, contribuem para o envolvimento do jogador e seu engajamento na história que perpassa o jogo. Como se trata de uma viagem no tempo, não é inverossímil que vejamos as pessoas congeladas embora possamos andar entre elas e pelos espaços que elas habitam ou frequentam. Essa crença na história é respaldada pela atitude lúdica que o jogador se propõe adotar ao aceitar o convite que o jogo lhe faz de lançar-se para outro tempo a procura de objetos que reconstituam o tempo presente.

Como conclusão, a partir do que foi colocado, podemos dizer que o jogo preza por garantir a imersão do jogador, favorecendo-a por meio de uma agência coerente com o ambiente e com a proposta do jogo.

\subsection{Bibliografia de referência para o game Cozinheiro das Almas}

ABRIL CULTURAL. Nosso Século 1900/ 1910 (I) e (II). São Paulo: Abril Cultural, 1985.

AMERICANO, J orge. São Paulo naquele tempo (1895-1915). São Paulo: Carbono 14, Narrativa Um, Carrenho Editorial, 2004.

ANDRADE, Oswald de. 0 perfeito cozinheiro das almas deste mundo... Diário coletivo da garçonnière de Oswald de Andrade. São Paulo, 1918. Edição fac-similar. Textos: Mário da Silva Brito e Haroldo de Campos. Transcrição tipográfica de J orge Schwartz. São Paulo: Ex Libris, 1987.

ANDRADE, Oswald de. Os condenados. São Paulo: Círculo do Livro, s/d.

ANDRADE, Oswald de. Um homem sem profissão. São Paulo: Editora Globo, 2002. 
CASA PAULISTANA DE COMUNICAÇÃO. Casas paulistanas: pequenos tesouros da Mooca na transformação de São Paulo. São Paulo: Casa Paulistana de Comunicação, 1998.

CAVALCANTI, Pedro; DELION, Luciano. São Paulo: a juventude do centro. São Paulo: Grifo Proj etos Históricos e Editoriais, 2004

CORRÊA, Maria Elizabeth Peirão et alli. Arquitetura escolar paulista, 1890-1920. São Paulo: FDE, Diretoria de Obras e Serviços, 1991.

ELETROPAULO. A cidade da Light: 1899-1930. São Paulo: Departamento de Patrimônio Histórico: Eletropaulo, 1990.

ESCOLA NORMAL SECUNDÁRIA DE SÃO PAULO. O laboratório de psicologia experimental. São Paulo: Typ. Siqueira, Nagel \& Comp., 1914.

FERRAZ, Vera Maria de Barros (org.). Imagens de São Paulo: Gaensly no acervo da Light 1899-1925. São Paulo: Fundação Patrimônio Histórico da Energia de São Paulo, 2001.

HOMEM, Maria Cecília Naclério. O palacete paulistano e outras formas urbanas de morar da elite cafeeira, 1867-1918. São Paulo: Martins Fontes, 1996.

IDOETA, Irineu; IDOETA, Ivan Valeije; CINTRA, J orge Pimentel. São Paulo vista do alto - 75 anos de aerofotogrametria. São Paulo: Érica, 2004.

INSTITUTO CULTURAL ITAÚ. Praça da República 1ạ ed. (1995) 2ạ reimpr. São Paulo: Instituto Cultural Itaú, 1997. (Cadernos da Cidade de São Paulo; 13).

INSTITUTO CULTURAL ITAÚ. Praça da Sé. 2a ed. rev. ampl. (1994) 1aㅡ reimpr. São Paulo: Instituto Cultural

JANOVITCH, Paula Ester (curadoria). Ver São Paulo. Catálogo de exposição, Conjunto Cultural da Caixa, 2005.

LEFÈVRE, J osé Eduardo de Assis. De beco a avenida, a história da rua São Luiz. São Paulo: Edusp, 2006. 
LEMOS, Carlos A. C. O álbum de Afonso: a reforma de São Paulo. Projeto e curadoria: Emanoel Araujo. São Paulo: Pinacoteca do Estado, 2001.

MAIA, Francisco Prestes. Os melhoramentos de São Paulo. São Paulo: Prefeitura Municipal de São Paulo, 1945.

MATTAR, Denise (curadoria). No tempo dos modernistas. D. Olívia Guedes Penteado, a senhora das artes. São Paulo: MAB : Faap, 2002.

MONARCHA, Carlos. Escola Normal da Praça, o lado escuro das luzes. Campinas, Editora Unicamp, 1999.

OLIVEIRA, Mirtes Cristina Marins. Palimpsestos: fotografias da Escola Normal da Praça (1889-1910), São Paulo: tese de doutorado na área de educação. PUC/SP, 2002.

PINTO, Alfredo Moreira. A cidade de São Paulo em 1900. Edição fac-similar. São Paulo: Governo do Estado de São Paulo, 1979.

PIRES, Mário J orge. Sobrados e barões da velha São Paulo. Barueri (SP): Manole, 2006.

PONTES, José Alfredo Vidigal. São Paulo de Piratininga: de pouso de tropas a metrópole. São Paulo: O Estado de S. Paulo : Editora Terceiro Nome, 2003.

PORTELA, Fernando. São Paulo 1860-1960: a paisagem humana. São Paulo: Editora Terceiro Nome: Louveira, SP: Albatroz Editora e Produtora, 2004.

RELATÓRIO do Director da Escola Normal, São Paulo: Tipografia do Diário Oficial, 1893.

RELATÓRIO do Director da Escola Normal, São Paulo: Tipografia do Diário Oficial, 1895.

RELATÓRIO do Director da Escola Normal, São Paulo: Tipografia do Diário Oficial, 1896. 
REIS, Nestor Goulart. 1860-1960 - Aspectos da história da engenharia civil em São Paulo. São Paulo: Livraria Kosmos Editora, 1989.

RESENDE, Beatriz (org.). Cocaína - literatura e outros companheiros de ilusão. Rio de J aneiro: Casa da Palavra, 2006.

REVISTA do J ardim da Infância, 1o volume. São Paulo: sem dados de editora, 1896.

SÃO PAULO (cidade). São Paulo antigo: plantas da cidade. São Paulo: Comissão do IV Centenário da cidade de São Paulo. Serviço de Comemorações Culturais, 1954.

SÃO PAULO (estado). São Paulo em três tempos: álbum comparativo da cidade de São Paulo (1862-1887-1914). São Paulo: Imprensa Oficial do Estado de São Paulo, 1982.

SOARES, Dulce. Barra Funda: esquinas, fachadas e interiores. São Paulo: Imprensa Ofical do Estado S.A., 1982.

TÁCITO, Hilário (José Maria de Toledo Malta). Madame Pommery. São Paulo: Monteiro Lobato \& Cia. Editores, 1919.

WOLFF, Silvia Ferreira Santos. Espaço e Educação: Os primeiros passos da arquitetura das escolas públicas paulistas, São Paulo: dissertação de mestrado na área de arquitetura. FAU/ USP, 1992. 


\section{Conclusão}

“De alguma forma, através de um estranho e maravilhoso paradoxo, aquelas declarações obrigatórias e restritivas que são as regras do jogo, quando postas em marcha no âmbito seguro do círculo mágico, misteriosamente criam a oportunidade para jogar". (Fullerton, 2008: 49)

Este trabalho buscou entender os elementos que possibilitam o envolvimento do jogador com o jogo, em especial, as regras e o gameplay.

Se regras e gameplay, em conjunto com os demais elementos do jogo, constroem a experiência do jogador, os dois primeiros têm importância fundamental por serem os elementos que definem o jogo e exprimem a experiência do jogador, que acreditamos, deva ser significante e divertida. Entender como esta experiência se constrói e como cada elemento trabalha para o engajamento do jogador foi o nosso objetivo.

O estudo e entendimento dos diversos conceitos de jogo nos permitiu identificar os elementos essenciais à sua constituição. Partindo da observação de que um jogo só existe como tal quando posto em movimento pelo jogador, temos como elementos passíveis de análise, o jogo, o jogador e a intersecção existente entre jogo e 
jogador, representada pelo ato de jogar. 0 jogo, enquanto artefato, possui algumas características, enquanto outras dependem do jogador colocá-lo em movimento. Desta observação decorre a divisão que estabelecemos, distinguindo os elementos essenciais dos jogos em inerentes a ele e decorrentes do ato de jogar.

Como inerentes ao jogo consideramos: as regras e as mecânicas do jogo, os objetivos que orientam o jogador, a interação do jogador com as regras e com 0 espaço artificial, separado da vida cotidiana em que ele se desenrola (que denominamos arena) e o fato de ser voluntário e incerto. São decorrentes do ato de jogar: o gameplay, os resultados alcançados (em função dos objetivos propostos), a competição que se estabelece e o faz de conta que perpassa a interação do jogador com o ambiente do jogo.

Desta primeira classificação, estabelecemos o que entendemos ser cada um destes elementos, como resumido a seguir.

Entendemos as regras como responsáveis por determinar o que o jogador pode ou não pode fazer e o que acontece em virtude de suas escolhas, orientando sua ação no sentido de produzir resultados significativos no âmbito do jogo. Devem ser claras e não ambíguas de forma que sua compreensão contribua para que o jogador possa desenvolver um estilo pessoal de jogo em função de seu repertório e suas 
habilidades, contribuindo para que o jogo proporcione ao jogador uma experiência prazerosa e significativa.

As mecânicas de jogo são o conjunto de elementos disponíveis para a interação e modificação do estado de jogo, a partir da agência tanto do jogador quanto dos agentes artificiais controlados pela Inteligência Artificial (IA).

Os objetivos podem ser propostos pelo jogo ou estipulados pelo próprio jogador. Mesmo que o jogo tenha um objetivo explícito, o jogador pode adotar outra postura e estabelecer para si um objetivo (ou vários) diferente(s) daquele do jogo, tornando sua experiência de jogar ainda mais particular. E este objetivo particular pode ser complementar ou diverso do proposto pelo jogo.

As interações são as ações do jogador que modificam o ambiente do jogo e o coloca em funcionamento. É um dos componentes importantes para o envolvimento do jogador, ao Ihe proporcionar a sensação de estar no comando do jogo, mesmo que suas ações estejam dentro das limitações impostas pelo programa. Deve ser entendida em termos de agência.

Arena refere-se ao espaço regido pelas regras específicas do jogo, delimitado artificialmente, separado da vida cotidiana, em que o jogo acontece. Nos videogames pode ir além do espaço da tela visualizado pelo jogador, abrangendo todo o sistema de mundo no qual o jogo se desenrola. Por definir os limites em que 
o jogo se desenrola é responsável por colocar o jogador "dentro do jogo", o que contribui para seu envolvimento e imersão no ambiente do jogo.

É fundamental que o jogo seja voluntário. A livre opção por participar do jogo está íntima e diretamente ligada ao que consideramos ser a função primordial dos jogos: ser um passatempo divertido e prazeroso para quem dele participa. 0 prazer de jogar reside, em parte, no fato deste ser uma atividade voluntária.

O fato de o jogo ser incerto é uma das características que faz dele uma atividade interessante. Parte de sua atração está na indefinição e incerteza do final, que gera elementos de tensão que envolvem o jogador.

O gameplay emerge das interações do jogador com uma determinada construção Iúdica, a partir de seu envolvimento com as regras e da manipulação de suas mecânicas, por meio da criação de estratégias e táticas que constroem a experiência de jogar.

Os resultados são considerados inerentes ao ato de jogar tanto por serem definidos em função dos objetivos propostos quanto porque só podem ser alcançados se 0 jogo for posto em movimento. Os resultados podem ser considerados parciais, quando o jogador suspende temporariamente 0 ato de jogar, deixando o jogo para ser continuado mais tarde, ou finais, quando o jogador termina o jogo alcançando ou não o resultado esperado ou quando simplesmente desiste de jogar. 
A competição se estabelece ou quando o jogador cria um desafio para si mesmo, propondo-se vencer o jogo, ou buscando se superar, ou comparando seus resultados com os de outros jogadores, estabelecendo um ranking. É decorrente dos desafios presentes no jogo e, tal como os resultados, apenas se institui a partir do momento em que o jogo é jogado.

O faz de conta deve aqui ser entendido no mesmo sentido dado por Caillois ao se referir ao jogo como fictício, proporcionando uma crença especial de uma segunda realidade ou de uma livre irrealidade, contrária à vida real. Este senso de faz de conta é responsável por tornar nossas ações significativas dentro do ambiente de jogo e instaura-se quando nos entregamos ao universo criado pelas regras e aceitamos suas condições.

As regras e o gameplay mereceram uma atenção especial, porque os consideramos os elementos primordiais para o envolvimento do jogador.

As regras organizam os jogos e a experiência do jogador. Consideramos relevante compreender seu papel por serem importantes na definição das características e da originalidade de um jogo. Alterações podem gerar pequenas variações ou um jogo completamente novo, em função do grau destas alterações. 
Ao levantarmos conceitos de regra propostos por diversos autores, derivamos 0 conceito já apresentado, que consideramos o que melhor a define. Observamos também que diversos autores tentaram tipificá-la, partindo das funções que seus tipos desempenham na organização dos jogos.

Da análise destas categorizações, notamos que suas semelhanças apontavam para a categorização proposta por Frasca (1997) como a mais concisa. No entanto, sentimos a necessidade de subdivir o que o autor chamou de regras de desenvolvimento em duas outras categorias (regras regentes e regras orientadoras) para melhor acolher as diferenças apontadas pelos outros autores.

A compreensão das funções de cada dos seus tipos ajuda a pensar e organizar a experiência do jogador.

As regras de desenvolvimento são as responsáveis por guiar o desenrolar do jogo, e por isso, são em parte responsáveis por manter o engajamento do jogador. As regras de desenvolvimento se subdividem em regras regentes e regras orientadoras. As regentes determinam o funcionamento geral do jogo, definem o que o jogador pode ou não fazer, e indicam a ele como suas ações se conectam. Já as regras orientadoras guiam o jogador em sua busca por um objetivo, permitem-Ihe estabelecer um plano de ação, suas estratégias de jogo, e com isso, ajudam-no a definir seu estilo pessoal. 
As regras de resultado definem o resultado final dos jogos e dividem-se em regras de triunfo e regras de derrota. As regras de triunfo definem como se vence um jogo, em que condições um jogador pode declarar-se vencedor. Já as regras de derrota definem o oposto, definem as condições em que a derrota ocorre. Quando são inversas às regras de triunfo não são tão relevantes. Mas adquirem maior importância nos casos em que o jogo não possui regras de triunfo, uma vez que a proposta é uma superação do próprio jogador e, nestes casos, são elas que definem o final do jogo mesmo sem a vitória do jogador.

Da interação do jogador com o jogo, a partir de seu envolvimento com as regras e da manipulação de suas mecânicas, emerge o gameplay, responsável por proporcionar ao jogador uma experiência significante e divertida.

0 primeiro problema com que nos deparamos ao tratarmos do gameplay foi a sua conceituação e a validade ou não de sua tradução pela palavra jogabilidade. 0 termo jogabilidade ainda não se encontra em nenhum dicionário de língua portuguesa. Mesmo assim, em sites e revistas especializadas, o termo é frequentemente utilizado, sem que Ihe deem uma definição exata, como que partindo do pressuposto de se tratar de um termo corriqueiro; quando esta definição aparece é atribuída à Wikipedia, e não encontra-se mais online. Já o termo gameplay pode ser encontrado em alguns (mesmo que ainda poucos) dicionários de língua inglesa, mas sem um consenso com relação a sua definição. 
A mesma falta de unanimidade pode ser observada entre os diversos autores que apresentam suas definições, sem chegarem a um consenso. Analisamos e comparamos diversas definições e pudemos observar que a experiência que o jogo proporciona ao jogador é o ponto principal da maior parte delas. Outro ponto comum foi o fato de ser decorrente da interação do jogador com jogo. A diversão como resultado é um terceiro ponto que consideramos relevante.

Comparando as definições de gameplay e jogabilidade, notamos que a menção à forma como o jogador interage com a mecânica do jogo está presente em ambas. No entanto, a definição de jogabilidade não leva em consideração o envolvimento (e a diversão) do jogador. $E$, devido à importância que o envolvimento do jogador tem nas diversas definições de gameplay encontrada, não poderíamos considerar os termos como equivalentes. Além disso, como nos lembra Assis (2007:19) “'jogabilidade' admite graus: alta ou baixa, o que não combina com um conceito abstrato". Disto decorre nossa opção pelo uso do termo no original.

A discussão de gameplay partiu da elaboração de uma síntese dos discursos em língua inglesa, organizando-os na definição já apresentada. Assim como os conceitos de jogo, a discussão sobre gameplay nos levou a observar que existem elementos que o constituem, como a atitude lúdica, a jogabilidade, a narrativa e a interface, e outros que nele interferem: imersão, agência e emergência. 
Os elementos que fazem parte do gameplay são os necessários para sua instauração e, em certa medida, relacionam-se aos elementos constituintes do jogo. A jogabilidade relaciona-se com a interação do jogador com as regras e o ambiente do jogo; a atitude lúdica com o fato do jogo ser voluntário; e os elementos que compõem a narrativa e a interface não deixam influenciar e sofrer influência dos objetivos, das regras e da mecânica do jogo, uma vez que seus desenvolvimentos são interdependentes.

$\mathrm{Na}$ construção do gameplay, enquanto elementos que nele interferem, consideramos que agência, emergência e imersão exercem influência direta sobre o jogador. Agência e imersão são dois conceitos baseados nos prazeres característicos do ambiente digital elencados por Murray (2003: 101-176). Não nos utilizamos do terceiro prazer citado por ela, a transformação, pois consideramos que com relação aos videogames, o conceito de emergência vai além da transformação, possibilitando não só a variedade em si como o surgimento de elementos inesperados e até inusitados.

De acordo com a definição de Murray (2003:127) agência é "a capacidade gratificante de realizar ações significativas e ver os resultados de nossas decisões e escolhas". Entendemos que ela se estabelece a partir do envolvimento do jogador com as regras e a partir da manipulação das mecânicas do jogo, criando estratégias e táticas que definirão o estilo de jogo adotado pelo jogador. Esta agência é restringida tanto pelas regras quanto pelas mecânicas, uma vez que estas 
definem um conjunto de escolhas possíveis, que são informadas ao jogador pela estrutura do jogo, e por meio das limitações que Ihe são apresentadas.

Imersão é a sensação que o jogador experimenta de se sentir envolvido com o jogo, ao mesmo tempo em que Ihe possibilita uma experiência particular, sem os riscos do mundo real.

Ryan (2001:120-157) parte da fenomenologia da leitura, e destaca um tipo específico de imersão, que pressupõe uma relação imaginativa com um mundo textual e aponta três tipos de imersão, que adaptamos para os videogames, observando um incremento de grau que acompanha a ordem de sua apresentação.

$\mathrm{Na}$ imersão espacial o jogador compartilha o local dos acontecimentos com os personagens e/ ou demais jogadores, sente-se inserido no mundo do jogo. Este é o primeiro grau de imersão, que observamos no momento em que o jogador entra no círculo mágico do mundo e deixa as preocupações cotidianas pra trás.

Depois de inserir-se no ambiente do jogo, o jogador entrega-se ao prazer que o jogo Ihe proporciona, desejando prolongar esta experiência. Esta é a imersão temporal, onde o jogador engaja-se em descobrir o que virá em seguida. 
A imersão emocional pode ser observada quando 0 jogador sente-se emocionalmente apegado ao jogo de forma que assume a personalidade do seu avatar e identifica-se com ele, refere-se a ele em primeira pessoa.

A imersão sinestésica, que não faz parte dos tipos identificados por Ryan, refere-se à aderência dos corpos dos jogadores aos movimentos do seu personagem, provocando reações em seus corpos sem passar pela atenção; diz respeito às sensações corporais provocadas pelos jogos. Além da identificação emocional, 0 corpo do jogador está envolvido nas ações e reações do jogador.

Emergência, o terceiro dos elementos que interferem no gameplay, pode ser definida como o surgimento de realidades complexas a partir da aplicação de regras simples. Em jogos onde a emergência predomina existem muitas formas de se alcançar o objetivo, geralmente definido de forma ampla, permitindo vários estados de jogo que se qualificam como este objetivo. A emergência permite uma grande rejogabilidade, uma vez que dificilmente a experiência de jogá-lo se repetirá. São jogos com regras simples que permitem diversas combinações, que por sua vez, permitem o desenvolvimento de diversos estilos de jogo.

Por fim, buscamos estabelecer relações entre as regras e o gameplay, observando as influências que se estabelecem entre eles. Consideramos regras e gameplay como elementos primordiais para a construção da experiência do jogador, que no 
entanto, elaboram esta experiência em conjunto com os elementos inerentes aos jogos e os constituintes do gameplay.

De forma sintética podemos dizer que quando o jogo apresenta um desafio ao jogador, que o coloca imerso no ambiente do jogo, a manipulação das mecânicas e da combinação das regras Ihe permitirá experimentar a emergência de novos elementos, decorrentes de sua agência sobre o jogo. Agência que, gerada a partir de escolhas informadas, se traduzirá pela realização de ações significativas, capazes de Ihe porporcionar uma experiência gratificante e prazerosa.

Por fim, este trabalho, em que organizamos e compilamos conceitos fundamentais para o entedimento dos jogos, nos fornece fundamentos e subsídios para pesquisas futuras que ampliem ainda mais o entendimento das formas de engajar o jogador, incrementando suas habilidades e seu repertório lúdico. 


\section{Bibliografia}

ANG, Chee Siang. "Rules, gameplay, and narratives in video games". In: Simulation Gaming, vol. 37, 2006. p. 306-325.

ARSENAULT, Dominic; PERRON, Bernard. "In the Frame of the Magic Cycle: The Circle(s) of Gameplay". In: PERRON, Bernard and WOLF, Mark J. P. The video game theory reader 2. New York: Routledge, 2009. p. 109-132.

ASCOTT, Roy. "The A-Z of Interactive Arts". Leonardo Eletronic Almanac, v.3, n.9, Set.1995. Disponível em: বhttp:// mitpress. mit.edu/ ejournals/ LEA/ ARTICLES/ ASCOTT4.html >. Acesso em: 02 jun. 2001.

ASSIS, Jesus de Paula. Artes do Videogame: conceitos e técnicas. São Paulo: Alameda, 2007.

AVEDON, Elliott; SUTTON-SMITH, Brian (eds). The Study of Games. New York: J ohn Wiley \& Sons, 1971. p. 405.

BATES, Bob. Game Design, 2nd Edition. Boston: Course Technology Press, 2004.

BAYLISS, Peter. "Notes Toward a Sense of Embodied Gameplay". In: AKIRA, Baba (ed.). Situated Play: Proceedings of the 2007 Digital Games Research Association Conference. Tokyo: The University of Tokyo, 2007. pp. 96-102. Versão eletrônica disponível em: বhttp:// www.digra.org/dl/db/07312.19059. pdf>. Acesso em 22 dez. 2009. 
BOBANY, Arthur. Videogame Arte. Teresópolis: Novas Ideias, 2008.

CAILLOIS, Roger. Le jeux el lês hommes. Lê masque el lê vertige. Cher, Gallimard, 1958. Tradução portuguesa com o título: Os jogos e os homens. A máscara e a vertigem. Lisboa: Cotovia, 1990.

CRAWFORD, Chris. The art of computer game design. Berkeley, CA: Osborne Press, 1984.

CRAWFORD, Chris. Chris Crawford on game design. New Riders Publishing, 2003.

COSTIKYAN, Greg. "I have no words and I must design" In: Interactive Fantasy \#2, 1994. Disponível em: «ttp://www.costik.com/nowords.html>. Acesso em: 16 jan. 2008.

CUPERSCHMID, Ana Regina Mizrahy. Heuristicas de jogabilidade para jogos de computador. Dissertação (Mestrado em Artes) - Instituto de Artes, Universidade Estadual de Campinas, Campinas, 2008. 154 p.

CUZZIOL, Marcos. Games 3D: Aspectos de desenvolvimento. Dissertação (Mestrado em Artes). Escola de Comunicação e Artes, Universidade de São Paulo, São Paulo. 2007. $95 \mathrm{p}$.

FEIL, J. H.; SCATTERGOOD, M. Beginning Game Level Design. Course Technology Press, 2005

FERREIRA, Emmanoel Martins. Games, Cinema e Interatividade. Trabalho apresentado no XXIX Congresso Brasileiro de Ciências da Comunicação, Intercom. UnB, Brasília, 2006. Disponível em: বhttp:// www.gamepad.com.br/ cont/ download/ games_cinema_e_interatividade.pdf>. Acesso em: 02 dez. 2006.

FRASCA, G. El videojuego como medio para una ficción interactiva: notas para una poética del joystick. Montevideo: Universidad Catolica del Uruguay, 1997. 
Disponível em: বhttp:// www. orbicom. uqam.ca/ english/ abstracts/ corpus/ frasca. html>. Acesso em: 20 nov. 2005.

FRASCA, Gonzalo. Ludology Meets Narratology: Similitude and differences between (video)games and narrative, 1999. Disponível em: বhttp://www.jacaranda.org/ frasca/index2.htm>. Acesso em: 22 nov. 2005.

FRASCA, Gonzalo. Videogames of the oppressed: Videogames as a means for critical thinking and debate. Dissertação (Master of Information Design and Technology) School of Literature, Communication and Culture, Georgia Institute of Technology, Atlanta, EUA, 2001. Disponível em: «ttp://www. ludology.org>. Acesso em: 20 nov. 2005.

FULLERTON, Tracy. Game design workshop: a playcentric approach to creating innovative games. Morgan Kaufmann/Elsevier, $2^{\text {nd }}$ ed., 2008.

GENVO, Sébatien. "Understanding Digital Playability". In: PERRON, Bernard and WOLF, Mark J. P. The video game theory reader 2. New York: Routledge, 2009. p. 133-149.

GINGOLD, Chaim. Miniature gardens \& magic crayons: Games, spaces, \& worlds, 2003. Disponível em: «ttp:// www. slackworks.com/ cog/writing/thesis/ >. Acesso em: 13 jun. 2008.

GOMES, Renata. Agentes verossímeis: uma investigação sobre a construção dos personagens autômatos nos videogames. Tese (Doutorado em Comunicação e Semiótica). Pontifícia Universidade Católica de São Paulo, São Paulo, 2008.

HEATON, Tom. "A Circular Model of Gameplay" In: Gamasutra.com, 2006. Disponível em বhttp:// www. gamasutra.com/view/ feature/2569/a_circular_model_ of_gameplay.php>. Acesso em: 11 set. 2009. 
HOWLAND, G. The focus of gameplay, 1999. Disponível em: বhttp:// www.lupinega mes.com/articles/focus_gameplay.html>. Acesso em: 11 jun. 2008.

HUIZINGA, J ohan. Homo Ludens. Haarlem, The Netherlands: H.D. Tjeenk Willink \& Zoon N.V., 1938. Tradução brasileira com o título: Homo Ludens. São Paulo: Perspectiva, 1980.

J ÄRVINEN, Aki. "Making and breaking games: A typology of rules". In: COPIER, Marinka and RAESSENS, Joost (ed.). Level Up: Digital Games Research Conference Proceedings. Utrecht: Utrecht University, 2003. pp. 68-79. Versão eletrônica disponível em: «ttp:// www.digra.org/dl/ db/05163.56503.pdf>. Acesso em 22 dez. 2009.

J OHNSENL, K. K. Narration in computer games. Dissertação - IT University of Copenhagen, Dinamarca, 2003. Disponível em: বhttp://www.detlillerum.dk/ itu/ NiCG02.pdf>. Acesso em: 13 jun. 2008.

JOHNSON, Steven. Emergence: The connected lives of ants, brains, cities and software. London: Penguin, 2001.

J UUL, J esper. What computer games can and can't do. Artigo apresentado no Digital Arts and Culture conference in Bergen, 2000. Disponível em: «ttp://www. jesperjuul. net/ text/ wcgcacd. html $>$. Acesso em 24 jan. 2008.

JUUL, Jesper. "The Game, the Player, the World: Looking for a Heart of Gameness". In: COPIER, Marinka and RAESSENS, Joost (ed.). Level Up: Digital Games Research Conference Proceedings. Utrecht: Utrecht University, 2003. pp. 3045. Versão eletrônica disponível em: «ttp://www.jesperjuul.net/text/ gameplayerworld/ >. Acesso em: 10 abr. 2009. 
JUUL, J esper. "Introduction to Game Time". In: WARDRIP-FRUIN, Noah and HARRIGAN, Pat (ed.) First Person: New Media as Story, Performance, and Game. Cambridge, Massachusetts: MIT Press, 2004. pp. 131-142. Versão eletrônica disponível em বhttp://www.jesperjuul.net/text/timetoplay/ >. Acesso em: 10 jul. 2008.

JUUL, J esper. Half Real: Video Games between Real Rules and Fictional Worlds, MIT Press, 2005.

LANTZ, Frank; ZIMMERMAN, Eric. Rules, Play and Culture: Towards an Aesthetic of Games, 1999. Disponível em: বhttp://www.ericzimmerman.com/texts/ RulesPlay Culture.htm>. Acesso em: 05 dez. 2006.

LE DIBERDER, Alain \& Frédéric. Qui a peur des jeux vidéo? Paris: Éditions La Découverte, 1993.

LÉVY, Pierre. Cibercultura. São Paulo: Editora 34, 1999.

LINDLEY, Craig A. "The gameplay gestalt, narrative, and interactive storytelling". In: MÄYRÄ, Frans (ed.) Proceedings of Computer Games and Digital Cultures Conference. Tampere, Finlândia: Tampere University Press, 2002. Disponível em: বhttp:// www. digra.org/ dl/db/05164.54179>. Acesso em: 25 nov. 2005.

LOPES, Maria Conceição. "Ludicity - a theoretical term". Sixth Annual Convention of Media Ecology Association. New York: Fordham University, Lincoln Centre Campus, 2005. Disponível em: «ttp:// www.csuchico.edu/kine/tasp/ 06prespapers/lopesludicitypaper.pdf >. Acesso em: 10 ago. 2009.

LOPES, Paulo; ROQUE, Licínio. Digital game evaluation, a formal approach. Disponível em: বhttp://www.jetcube.eu/msc/sem1-article-l.pdf>. Acesso em: 07 jan. 2010. 
LUZ, Alan Richard da. Linguagens Gráficas em Videogame. Dissertação (Mestrado em Design e Arquitetura). Faculdade de Arquitetura e Urbanismo, Universidade de São Paulo, São Paulo. 2009. 167 p.

MACHADO, Arlindo. "Regimes de Imersão e Modos de Agenciamento". In: XXV Congresso Brasileiro de Ciências da Comunicação - Intercom, 2002, Salvador. Anais do XXV Congresso Brasileiro de Ciências da Comunicação. Salvador : UNEB. Versão eletrônica disponível em: বhttp://www.comunidadesvirtuais.pro.br/hipertexto/ home/ Imersao e Agenciamento - Machadotext05. pdf>. Acesso em: 07 jan. 2010.

MURRAY, J anet H. Hamlet no Holodeck. O futuro da narrativa no ciberespaço. São Paulo: Itaú Cultural: Unesp, 2003. Tradução brasileira do original: "Hamlet on the holodeck: The future of narrative in cyberspace". New York: Free Press, 1997.

MURRAY, J anet H. "The Last Word on Ludology vs Narratology in Game Studies". In: Proceedings of DiGRA; 2005. Versão eletrônica disponível em: «ttp://www. Icc. gatech. edu/ murray/ digra05/lastword. pdf>. Acesso em 06 jan. 2010.

MURRAY, J anet H. "Toward a Cultural Theory of Gaming: Digital Games and the CoEvolution of Media, Mind, and Culture", Popular Communication, 4(3), 185-202 2006. Versão eletrônica disponível em: বhttp://egl.gatech.edu/publications/ PC0403_Murray.pdf $>$. Acesso em 06 jan. 2010.

NESTERIUK, Sérgio. A narrativa do jogo na hipermídia: a interatividade como possibilidade comunicacional. Dissertação (Mestrado em Comunicação e Semiótica). Pontifícia Universidade Católica de São Paulo, São Paulo. 2002.

NESTERIUK, Sérgio. J ogo como elemento da cultura: aspectos contemporâneos e as modificações na experiência do jogar. Tese (Doutorado em Comunicação e Semiótica). Pontifícia Universidade Católica de São Paulo, São Paulo, 2007. 
NIEUWDORP, Eva. "The Pervasive Interface: Tracing the Magic Circle". In: Proceedings of DiGRA; 2005. Versão eletrônica disponível em: «ttp://www. digra. org/ dl/ db/ 06278.53356. pdf>. Acesso em 22 dez. 2009.

PARLETT, David. The Oxford History of Board Games. New York: Oxford University Press, 1999. p.1. apud SALEN \& ZIMMERMAN, p. 74.

PRADO, Gilbertto. "Redes e ambientes virtuais artísticos". In: RUA - Revista Universitária do Audiovisual, v. 1, p. 1-10, 2008.

PRADO, G.; DIGITAIS, Grupo Poéticas. "Apontamentos para o game Cozinheiro das Almas". In: Texto Digital (UERJ), Florianópolis, SC, v. 2, 2006.

PRADO, G.; LAURENTIZ, Silvia Regina Ferreira de. "Uma leitura poética de ambientes virtuais multiusuário". In: ARS (USP), São Paulo, v. 3, p. 22-35, 2004.

PRADO, G.; ASSIS, J esus de Paula. "Imateriais99 e Desertesejo: dois experimentos brasileiros recentes em ambientes virtuais multiusuário". In: Geraes (UFMG), Belo Horizonte, MG, v. 53, n. 53, p. 74-81, 2002.

PEDERSEN, R. E. Game Design Foundations. Wordware Publishing Inc, 2003.

PERRON, Bernard; WOLF, Mark J. P. The video game theory reader 2. New York: Routledge, 2009.

PIAGET, Jean. La Formation du Sembole chez l'enfant imitation, Jeu et Rêve, image et Représentation. Neuchâtel, Suíça : Editions Delachaux et Niestlé, 1964. Tradução brasileira com o título: "A formação do símbolo na criança: imitação, jogo e sonho, imagem e representação". Rio de J aneiro : Zahar, 1971.

PRENSKY, Marc. Digital Game-Based Learning. New York: McGraw-Hill, 2001. 
PRIMO, Alex; CASOL, Marcio. Explorando o conceito de interatividade: definições e taxonomias. Disponível em: বhttp://usr.psico.ufrgs.br/ a aprimo/pb/pgie.htm>. Acesso em: 27 nov. 2006.

RANHEL, João. "O conceito de jogo e os jogos computacionais". In: SANTAELLA, Lucia e FEITOZA, Mirna (org.) Mapa do Jogo. São Paulo : Cengage Learning, 2009, p. 3-22.

ROLLINGS, Andrew; ADAMS, Ernest. Andrew Rollings and Ernest Adams on game design. New Riders Publishing, 2003.

ROLLINGS, Andrew; MORRIS, Dave. Game Architecture and Design: a New Edition. New Riders Games, 2003.

ROUSE, Richard. Game Design Theory and Practice. Wordware Publishing Inc., 2000

RYAN, Marie-Laure. Narrative as Virtual Reality: Immersion and Interactivity in Literature and Electronic Media. Baltimore: J ohns Hopkins University Press, 2001.

SALEN, Katie; ZIMMERMAN, Eric. Rules of Play: Game Design Fundamentals. MIT Press, 2003.

SANTAELLA, Lucia. Navegar no ciberespaço: o perfil cognitivo do leitor imersivo. São Paulo: Editora Paulus, 2004.

SANTAELLA, Lucia. "Games e comunidades virtuais". Artigo apresentado na exposição hiPer>relações eletro// digitais. Porto Alegre: Santander Cultural, 2004. Disponível em: বhttp:// www.canalcontemporaneo.art.br/tecnopoliticas/archives/ 000334. html >. Acesso em: 1 ago. 2005.

SANTAELLA, Lucia; FEITOZA, Mirna (org.) Mapa do Jogo. São Paulo : Cengage Learning, 2009. 
SATO, Adriana. "Do mundo real ao mundo ficcional: a imersão no jogo". In: SANTAELLA, Lucia e FEITOZA, Mirna (org.) Mapa do Jogo. São Paulo : Cengage Learning, 2009, p.37-48.

SICART, M., 2008. Defining Game Mechanics. In: Game Studies, 2 December 2008. Disponível em: «ttp://gamestudies.org/0802/articles/sicart>. Acesso em: 22 jul. 2009.

SUITS, Bernard. "What is a game?". In: Philosophy of Science, The University of Chicago Press, Vol. 34, No. 2 (J un., 1967), pp. 148-156.

SUITS, Bernand. Grasshopper: Games, Life and Utopia. Broadview Press, 2005. Originalmente publicado em 1978 pela University of Toronto Press.

SWEETSER, Penny. Emergence in games. Boston: Cengage Learning, 2008.

TOSCA, Susana. The quest problem in computer games. Artigo apresentado na conferência Technologies for Interactive Digital Storytelling and Entertainment (TIDSE), Darmstadt, Alemanha, 2003. Disponível em: বhttp://www.itu.dk/people/ tosca/ quest.htm>. Acesso em: 25 mar. 2009.

VANNUCCHI, Hélia; PRADO, Gilbertto. "Discutindo o conceito de gameplay". In: Texto Digital (UERJ), v. 5, p. 1-6, 2009.

WALTHER, B. K. Brincando e Jogando - Reflexões e Classificações. Artigo apresentado no FILE - Festival Internacional de Linguagem Eletrônica, 2005. Disponível em: বhttp:// www.file.org.br/file2005/textos/ games/ port/ playing_and_ gaming. doc $>$. Acesso em: 7 out. 2007. 



\section{Gameografia}

Na relação abaixo, quando um dos videogames faz parte de uma série, a data refere-se ao lançamento do primeiro deles.

Banco Imobiliário (Monopoly), Estrela, 1944. [Tabuleiro]

Bejeweled, PopCap Games, 2001. [Videogame]

Braid, Number None, 2008. [Videogame]

Campo Minado (Robert Donner), 1989. [Videogame]

Civilization (Sid Meier), Microprose/ Firaxis Games, 1991. [Videogame]

Cogs, Lazy 8 Studios, 2009. [Videogame]

Counter-Strike, Valve Software, 1999. [Videogame]

Cozinheiro das Almas, Grupo Poéticas Digitais, 2006. [Videogame]

Donkey Kong, Nintendo, 1981. [Videogame]

Doom, id Software, 1993. [Videogame]

EverQuest, Verant Interactive, 1999. [Videogame]

Four, Philos Games, 2005. [Tabuleiro] 
Genius, Estrela, 1980. [Eletrônico]

Grim Fandango, LucasArts, 1998. [Videogame]

Half-Life, Valve Software, 1998. [Videogame]

Half-Life 2, Valve Software, 2004. [Videogame]

Indiana J ones e a Última Cruzada, LucasArts, 1989. [Videogame]

Lig-4, Estrela, 1976. [Tabuleiro]

Might \& Magic, New World Computing, 1987. [Videogame]

Monkey Island, LucasArts, 1993. [Videogame]

Monkey Trouble 2, Crystal Squid, 2009. [Videogame]

Monopoly (Charles Darrow), Parker Brothers, 1935. [Tabuleiro]

Mortal Kombat, Midway Games, 1992 [Videogame]

Myst, Cyan Worlds, 1993. [Videogame]

Pong (Nolan Bushnell, Ted Dabney), Atari, 1972. [Videogame]

Quake III Arena, id Software, 1999. [Videogame]

Resta Um, anônimo, c. 1789. [Tabuleiro]

Risk, Parker Brothers, 1959. [Tabuleiro] 
Sim City (Will Wright), Eletronic Arts Games, 1989. [Videogame]

Simulator X, Microsoft, 2006. [Videogame]

Sliding puzzle (Noyes Chapman), c. 1874. [Tabuleiro]

Sonic, Sega, 1991. [Videogame]

Space Invaders (Tomohiro Nishikado), Taito Corporation, 1978. [Videogame]

Super Mario Bros. (Shigeru Miyamoto), Nintendo, 1985. [Videogame]

Super Model, Toyster, 2004. [Tabuleiro]

Tetris (Alexey Pajitnov), 1984. [Videogame]

The Elder Scrolls IV: Oblivion, Bethesda Softworks, 2006. [Videogame]

The Legend of Zelda, Nintendo, 1986. [Videogame]

The Sims (Will Wright), Eletronic Arts Games, 2000. [Videogame]

Vampire: The Masquerade - Bloodlines, Troika Games, 2004. [Videogame]

War (Risk), Grow, 1972. [Tabuleiro]

Warcraft III, Blizzard Entertainment, 2002. [Videogame] 